\author{
Universidade de São Paulo \\ Museu de ARQueologia e EtNologia \\ Programa de Pós-Graduação em Arqueologia
}

MuSEALIZAÇÃo dA ARQUEOLOGIA: DIAGNÓSTICO DO PATRIMÔNIO ARQUEOLÓGICO EM MUSEUS POTIGUARES

Abrahão SANDERSOn Nunes F. Da SiLVA

SÃo PaUlo

2008 


\author{
UNIVERSIDAde de SÃo PaUlo \\ MUSEU DE ARQUEOLOGIA E ETNOLOGIA \\ Programa de Pós-Graduação em Arqueologia
}

\title{
MUSEAlizAÇÃo da ArQUEOLOGIA: DiAgNóSTiCO DO PATRIMÔNIO ARQUEOLÓGICO EM MUSEUS POTIGUARES
}

AbraHÃo SANDERSON NUNES F. DA SILVA

Dissertação apresentada ao Programa de PósGraduação em Arqueologia, do Museu de Arqueologia e Etnologia da Universidade de São Paulo, para a obtenção do título de Mestre em Arqueologia.

Orientadora: Profa. Dra. Maria Cristina Oliveira Bruno

LinHa de Pesquisa: MusealizaÇão da ARQueOlogia

São Paulo

2008 
Aos meus pais, Antonio e Hildete, meus irmãos, Anderson e Patrícia, e por minha noiva, Alenuska. 


\section{AgradeCimentos}

Se os caminhos da minha vida não houvessem me levado aonde estou hoje poderia até não acreditar em Deus, mas diante do que vivo não posso deixar de agradecer a Ele por mais este momento.

Aos meus Pais e Irmãos, pelo incentivo, pela ajuda e por guardarem um lugar naquela que será sempre a minha casa.

A Alenuska, por ter se tornado minha companheira de sonhos e por acreditar em mim mais do que eu mesmo.

Aos amigos e colegas de curso, pelas piadas, conversas tronchas, diálogos sobre arqueologia e momentos de descontração - obrigado por tornar este período da minha vida inesquecível.

A Arkley Bandeira, pela amizade e respeito e, também, por ter me ajudado a sobreviver longe de mainha e painho.

A galera da "República do Seu Pedro", em particular ao João Cabral por ter proporcionado um almoço que virou jantar de aniversário.

A Pró-Reitoria de Pesquisa da USP, pela bolsa CAPES (Demanda Social) concedida por sete meses.

Ao CNPq pela bolsa de mestrado concedida em abril de 2007, agradeço por este apoio que foi tão essencial em meus deslocamentos pelo interior do Rio Grande do Norte quando nas etapas de trabalho da pesquisa.

Aos professores do Programa de Pós-Graduação em Arqueologia do MAE/USP com quem tive a oportunidade de aprender e dialogar.

Aos funcionários do Museu de Arqueologia e Etnologia da USP pela atenção e respeito com que sempre me trataram.

A professora Marisa Coutinho Afonso e ao professor José Luiz de Morais pelas valiosas contribuições em meu exame de qualificação e, em particular, ao professor José Luiz por ter sugerido o título desta dissertação.

Ao professor Roberto Airon que, ainda em minha especialização, indicou o caminho de onde surgiu a idéia para o projeto de pesquisa de mestrado. 
Ao "monstro do armário", popularmente conhecido como Rodrigo, pela paciência ao me ouvir falar do mundo novo que conheci quando entrei no mestrado e pela amizade de sempre.

Ao "mucureba" do Péricles, amigo/irmão, por me escutar e me incentivar a ir à procura dos meus sonhos.

A Claudinha pelas palavras carinhosas, risadas, caminhadas, pelas fotos do Museu do Sertanejo e pelos sanduíches de "queijo lux".

Esta dissertação não teria sido possível sem o apoio dos diretores e funcionários das instituições abordadas neste trabalho. Agradeço o empenho em me disponibilizar documentos, textos e também por permitir o inventário dos acervos.

Ao professor Tom Miller, por ter me apresentado uma perspectiva da arqueologia norte-rio-grandense que eu ainda não conhecia e, a professora Francisca Miller por ter aberto as portas da casa de seu pai para que eu pudesse conversar com ele.

A professora Maria Cristina Oliveira Bruno por me ajudar a percorrer os caminhos da Musealização da Arqueologia, pela prontidão com que sempre respondeu aos emails, pelas leituras cuidadosas de meus textos, pela atenção que teve para comigo assim que aportei no MAE e, principalmente, pela confiança que sempre demonstrou em meu trabalho desde nosso primeiro contato em fevereiro de 2005. 


\section{RESUMO}

Título: "Musealização da Arqueologia: diagnóstico do patrimônio arqueológico em museus potiguares".

A formação de coleções museológicas no Brasil remonta ao século XIX, período de estabelecimento dos primeiros museus brasileiros. Na gênese destes museus encontra-se também a origem institucional da Arqueologia Brasileira, isto significa também dizer que desde esta época, em meio às coleções formadas no país constam aquelas compostas essencialmente por artefatos arqueológicos. As coleções arqueológicas quando inseridas no contexto dos acervos museológicos se mostram pouco articuladas com outros conjuntos patrimoniais, o que revela então camadas de relações que foram estabelecidas para com estes artefatos e evidencia um processo que destaca o isolamento e o esquecimento dos objetos arqueológicos enquanto elementos constituintes das memórias locais, regionais ou nacionais. Esta "estratigrafia do abandono" é observada no Rio Grande do Norte a partir das relações estabelecidas para com os acervos arqueológicos nos museus Câmara Cascudo, Lauro da Escóssia, Museu do Seridó, Museu do Sertanejo e Museu de Soledade. Assim, estudando realidades institucionais distintas, se busca contribuir para a percepção não só do potencial informativo (arqueológico ou histórico-cultural) e comunicativo (educação e relação com as identidades) das coleções arqueológicas potiguares, mas também para evidenciar a maneira como este campo do patrimônio cultural brasileiro tem sido abordado em terras norte-riograndenses.

Palavras-chave: Arqueologia, Musealização, Patrimônio, Museus, Coleções. 


\begin{abstract}
Title: "Archaeology Musealisation: a study of the archaeological heritage at museums potiguares".

The museums collections formation at Brazil its source in the $19^{\text {th }}$ century, when to appeared first brazilian museums. In the origin these museums it's also institutional origin brasilian archaeology, at this moment it's were formed archaeological collections. The archaeological collections not articulate with the others heritages, the archaeological objects it's isolated and forgotten. The archaeological workmanships it's don't do local memories, or national memories. This "stratigraphy of the abandonment" it's observed in Rio Grande do Norte, from this relations with archaeological collections at the museums Câmara Cascudo, Lauro da Escóssia, Seridó, Sertanejo and Soledade. The objective to the researching about institutional realities different is to contribute for the perception not only of the informative potential (archeological or historical-cultural) and communicative (education and relationship with the identities) of the archeological collections potiguares, but also to evidence the way as this bazilian cultural heritage it has been approached in Rio Grande do Norte.
\end{abstract}

Keywords: Archaeology, Musealisation, Heritage, Museums, Collections. 


\section{LISTA DE FIGURAS}

Figura 1. Localização dos municípios com instituições pesquisadas........................... 14

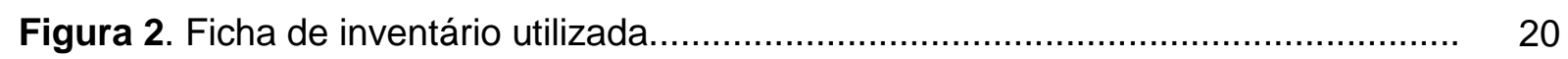

Figura 3. Artefatos líticos ensacados devido a "reforma" no MHLE ............................. 69

Figura 4. Mapa com origem de peças da coleção arqueológica do MHLE.................... 74

Figura 5. Municípios e siglas adotadas, durante a pesquisa de dissertação.................. 75

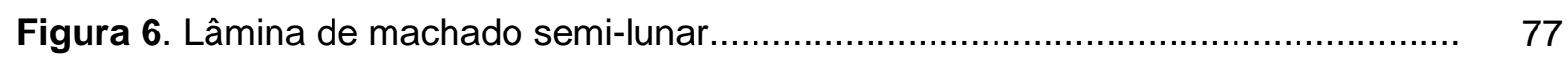

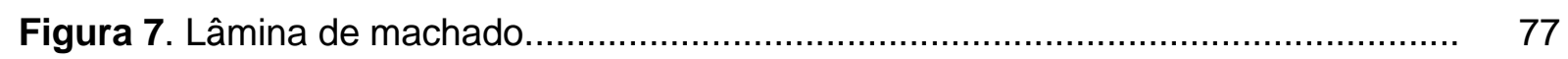

Figura 8. Ponta de projétil que integra a coleção arqueológica do MHLE...................... 77

Figura 9. Fornilhos de cachimbo da coleção arqueológica do MHLE........................... 79

Figura 10. Desenho de vasilhame cerâmico de Jucurutu/RN.................................. 79

Figura 11. Instrumento passivo, tipo mó - coleção arqueológica do MHLE................... 80

Figura 12. Ponta de projétil, coleção arqueológica do MHLE..................................... 80

Figura 13. Contas de colar, coleção arqueológica do MHLE..................................... 81

Figura 14. Adorno labial, Tembetá - coleção arqueológica do MHLE.......................... 81

Figura 15. Perfil estratigráfico do Sítio Bonito, em Jucurutu/RN............................... 102

Figura 16. Ponta de projétil que integrava a o acervo do MCC............................... 104

Figura 17. Escavação no sítio arqueológico Pedra do Letreiro.................................... 105

Figura 18. Lugares onde pesquisados pelo Dept. de Arqueologia do MCC................. 108

Figura 19. Primeiro Livro de Tombo do Dept. de Arqueologia do MCC....................... 109

Figura 20. Segundo Livro de Tombo do Dept. de Arqueologia do MCC...................... 109 
Figura 21. Página 20 do $2^{\circ}$ Livro de Tombo do Dept. de Arqueologia do MCC

Figura 22. Página 102 do 2ํㅡㄴ Livro de Tombo do Dept. de Arqueologia do MCC.

Figura 23. Exposição do MCC, cenário da pesca artesanal.

Figura 24. Exposição do MCC, maquete de um sambaqui.

Figura 25. Exposição do MCC, sala do ambiente pleistocênico.

Figura 26. Exposição do MCC, estratigrafia de um tanque natural.

Figura 27. Exposição do MCC, sala do ambiente cavernícola

Figura 28. Exposição do MCC, réplica da Mina Brejuí.

Figura 29. Exposição do MCC, sala da Arte e Religião Afro-Brasileiras

Figura 30. Exposição do MCC, sala dos mamulengos.

Figura 31. Exposição do MCC, sala 'Santeiros e Devoções'..... 120

Figura 32. Exposição do MCC, sala da Arqueologia no Rio Grande do Norte. 121

Figura 33. Exposição do MCC, mostruário com líticos e cerâmicas. 121

Figura 34. Exposição do MCC, texto sobre 'arqueologia no Rio Grande do Norte' 121

Figura 35. Exposição do MCC, moenda de cana-de-açúcar. 122

Figura 36. Exposição do MCC, sala dedicada a paleomastozoologia. 122

Figura 37. Exposição do MCC, sala da paleontologia 123

Figura 38. Exposição do MCC, sala da anatomia comparada. 123

Figura 39. Fachada do Museu do Seridó 133

Figura 40. Museu do Seridó, núcleo remanescente da exposição dos anos 1980. 134

Figura 41. Coleção arqueológica do Museu do Seridó 
Figura 42. Fachada do Museu do Sertanejo

Figura 43. Museu do Sertanejo, objetos relativos à pecuária seridoense...

Figura 44. Museu de Sertanejo, artefatos da coleção arqueológica.......

Figura 45. Museu do Sertanejo, ponta de projétil fragmentada.

Figura 46. Museu do Sertanejo, texto de Olavo de Medeiros Filho.

Figura 47. Fachada do Museu de Soledade.

Figura 48. Visita de turistas ao Lajedo de Soledade.

Figura 49. Museu de Soledade, fósseis encontrados no Lajedo de Soledade. 145

Figura 50. Museu de Soledade, expositores com artefatos líticos e cerâmicos. 146 


\section{SUMÁRIO}

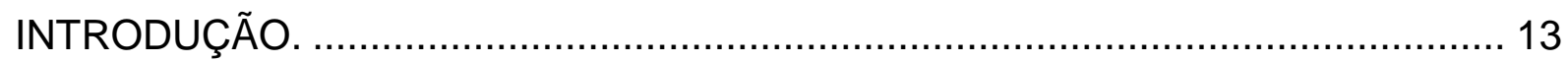

Os solos institucionais, ou, os capítulos que compõem esta Dissertação. ........... 23 CAPÍTULO I

Coleções, museus e identidades: elementos de uma relação entre patrimônio e arqueologia.

Da 'ressurreição do passado' em coleções à formação dos museus, passando pelo exótico dos gabinetes de curiosidades.

Os museus brasileiros, sua relação com os auspícios da Arqueologia no país e sobre a relação desta com a Museologia. 40

O Museu Real ou Museu Nacional 43

O Museu Paraense Emílio Goeldi 45

O Museu Paulista 47

Sobre patrimônio(s). 54

Identidades e museus no Nordeste do Brasil. 60 CAPÍTULO II

Museu Histórico Lauro da Escóssia: estratos de uma coleção arqueológica no Oeste potiguar. 64

Cria-se um museu, mudam-se as sedes 65

A Coleção Arqueológica do Museu Histórico Lauro da Escóssia. 71

O que nos conta a produção historiográfica local sobre os grupos autóctones do solo potiguar. 84

Assim, o que se pode então apreender desta cultura material? 88 CAPÍTULO III

Arqueografia dos estudos em pré-história e arqueologia no Museu Câmara Cascudo e a transposição expográfica destes estudos. 92

De 1965 aos anos 2000: as pesquisas acadêmicas e os trabalhos de arqueologia por contrato no âmbito do Museu Câmara Cascudo. 96

O gerenciamento da informação a partir dos Livros de Tombo. 109 
Uma visão acerca da exposição permanente do Museu Câmara Cascudo e sobre a inserção da Arqueologia nesta expografia. 114 CAPÍTULO IV

Da Fundação Amigos do Lajedo de Soledade ao museu universitário: outros aspectos da Musealização da Arqueologia no Rio Grande do Norte. ................... 127

Um pequeno histórico das pesquisas arqueológicas no Seridó potiguar............ 129

Os museus do Seridó e do Sertanejo e suas coleções arqueológicas. ............... 132

A pesquisa arqueológica no Lajedo de Soledade e o produto dos trabalhos: o Museu de Soledade. ........................................................................................... 140

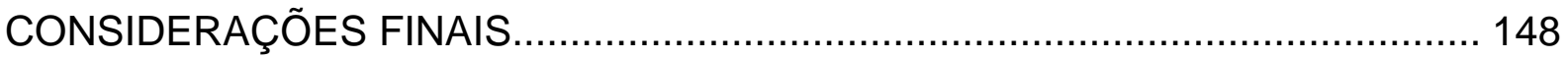

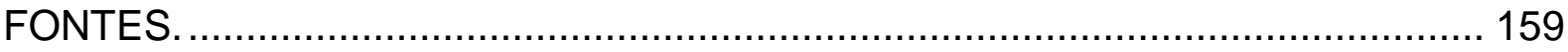

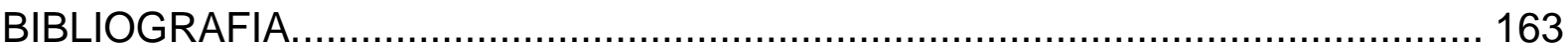


INTRODUÇÃO. 
A idéia de escrever esta dissertação, fundamentalmente, se apóia em uma preocupação com o patrimônio histórico-arqueológico norte-rio-grandense e as relações que se estabeleceram para com este no âmbito de cinco instituições museológicas do Rio Grande do Norte. Ou seja, nos interessamos por perceber a forma como os acervos arqueológicos foram formados e como são abordados nos museus universitários Câmara Cascudo e Seridó, nos museus municipais do Sertanejo e Lauro da Escóssia e, no museu de Soledade. Estas instituições estão localizadas em distintas porções do território potiguar, respectivamente, no litoral (na cidade do Natal), no Seridó (cidades de Caicó e Acari) e no Oeste (cidades de Mossoró e Apodi), conforme observado na figura 1.

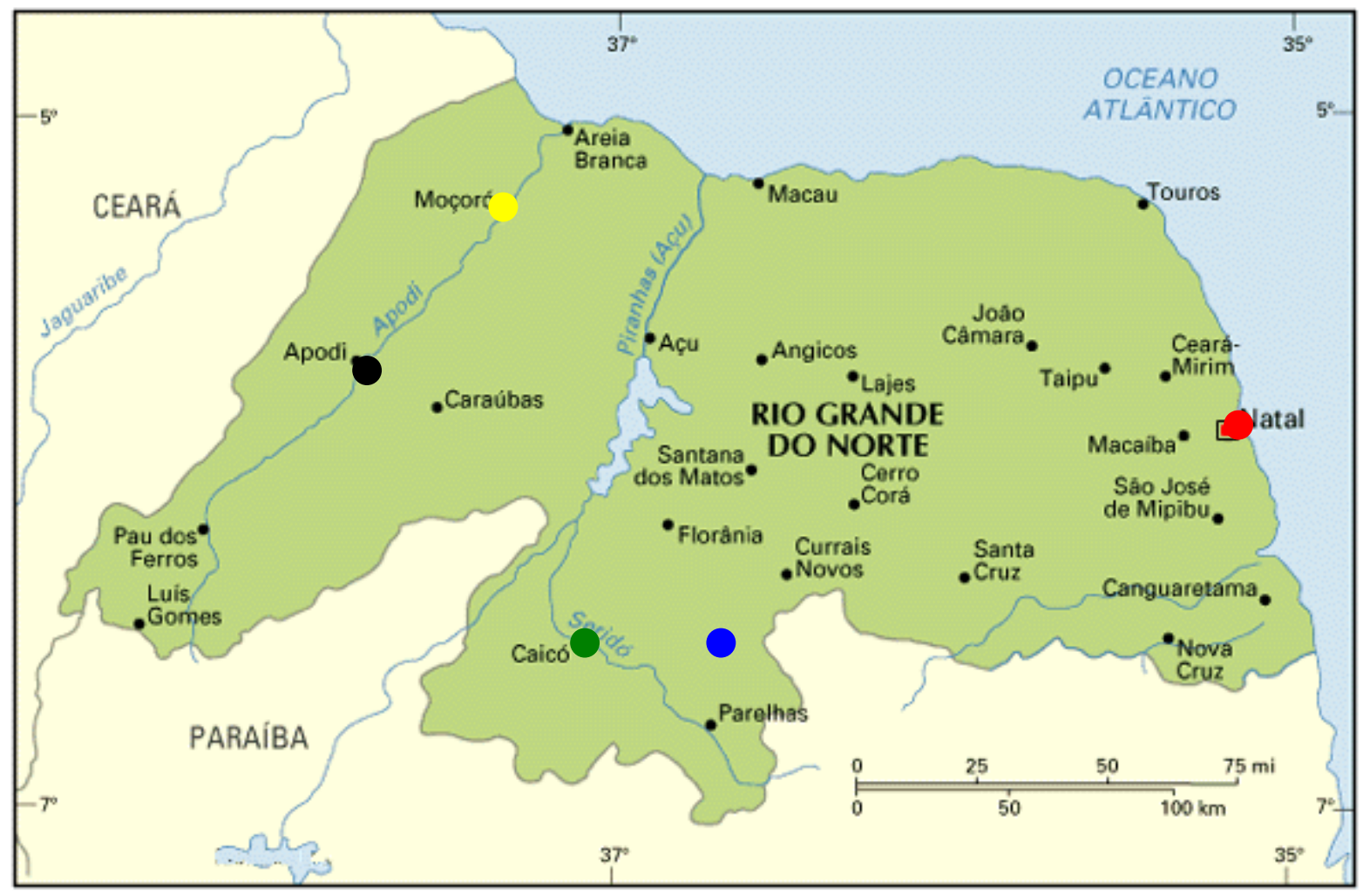

Figura 1. Mapa do Rio Grande do Norte, onde se assinala a localização aproximada dos municípios de Apodi (preto), Mossoró (amarelo), Caicó (verde), Acari (azul) e Natal (vermelho). FONTE: http://www.guianet.com.br/rn/maparn.htm

Estas instituições apresentam uma variação na forma como acessam e difundem este campo do patrimônio cultural brasileiro, deixando claro que "a constituição de uma memória está intimamente relacionada com as transformações 
que o presente lhe confere na reelaboração do passado" (ALMEIDA \& VASCONCELLOS, 2002: 107). Apesar disto manifestam uma característica comum que os une, a "estratigrafia do abandono" (BRUNO, 1995). Isto é, no plano dos museus locais estudados e também da historiografia local ${ }^{1}$ analisada se observa, de maneira análoga a um corte estratigráfico ${ }^{2}$, a formação de camadas que quando desveladas evidenciam

\begin{abstract}
"uma estratigrafia que sufocou e fossilizou os vestígios pré-coloniais, enquanto indicadores da nossa memória cultural. Esta estratigrafia do abandono é responsável pelo esquecimento das fontes arqueológicas e pela sua circunscrição no terreno das memórias exiladas" (BRUNO, 1995: 8 - Grifo nosso).
\end{abstract}

Em outras palavras, isto implica dizer que as coleções arqueológicas quando inseridas no contexto dos acervos museológicos se mostram pouco articuladas com outros conjuntos patrimoniais, o que revela então camadas de relações que foram estabelecidas para com estes artefatos e evidencia um processo que destaca o isolamento e o esquecimento dos objetos arqueológicos enquanto elementos constituintes das memórias locais, regionais ou nacionais - daí porque serem memórias exiladas.

De uma maneira mais ampla, podemos enxergar a formação dessa estratificação a partir do período vinculado à obra colonizadora, desde esta época já pode ser percebida uma estrutura que arregimentou valores e definiu objetos e objetivos nas terras conquistadas, inscitando assim um desapego ao passado nativo. Um exemplo disto pode ser notado na subjugação da oralidade e da "artefatualidade" nativas em favor das letras e da cultura material européia.

\footnotetext{
${ }^{1}$ A historiografia local analisada é composta pelas seguintes obras: CASCUDO, Luís da Câmara. História do Rio Grande do Norte. 2. ed. Rio de Janeiro: Achiamé/FJA, 1986; MONTEIRO, Denise. Introdução à história do Rio Grande do Norte. 2. ed. Natal: EDUFRN, 2002; LIRA, Tavares de. História do Rio Grande do Norte. 3. ed. Natal: IHGRN, 1997; MEDEIROS, Tarcísio de. Proto História do Rio Grande do Norte. Rio de Janeiro: Presença/FJA, 1985; POMBO, Rocha. História do Estado do Rio Grande do Norte. Rio de Janeiro: Annuario do Brasil, 1922.

2 Há duas noções de estratigrafia, uma geológica e outra arqueológica, que se cruzam e que tem por princípio básico as idéias de seqüência e sobreposição, donde a uma etapa anterior pretensamente mais antiga se segue uma mais recente. Souza (1997: 51 ) as caracteriza, respectivamente, como o estudo de camadas ou estratos que aparecem superpostos num corte geológico e, o estudo dos sucessivos pisos de ocupação ou assoalhos culturais.
} 
"Cabe ressaltar que este desprezo por características culturais tão fortes dos nativos, pode ser uma das principais razões para o esquecimento do seu passado. Como é conhecido, a oralidade é um elemento decisivo de comunicação entre os grupos indígenas. As histórias do passado, os mitos de origem, os ritos de passagem, as interpretações e representações do meio ambiente, entre tantos outros aspectos, têm na linguagem oral as possibilidades objetivas de preservação.

Desta mesma forma, os artefatos reúnem características importantes para a compreensão dos processos culturais, no que diz respeito à escolha e tratamento das matérias-primas, às diferentes técnicas de confecção e possibilidades de uso.

Assim, o passado pré-colonial ficou subjugado a olhares estrangeiros e indiferentes aos seus vestígios" (BRUNO, 1995: 11).

Há outras camadas nesta estratigrafia que são posteriores ao período colonial, como, por exemplo, o fato de que as elites econômicas do século XIX privilegiaram manifestações culturais de inspiração européia, contribuindo desta maneira para a imposição de pretensos traços culturais formadores da identidade nacional; ou a idéia de que a preservação de traços culturais de um passado précolonial implica em um obstáculo ao progresso; ou ainda o fato de que o avanço da pesquisa arqueológica não foi acompanhado por uma utilização dos dados gerados em trabalhos feitos, entre outros profissionais, por historiadores, sociólogos e antropólogos, preocupados em compreender e explicar a nação brasileira.

Não obstante tais situações, metaforicamente pensadas como camadas, talvez uma das principais dificuldades nesta problemática pensada em relação às fontes arqueológicas resida nas próprias posturas profissionais dos arqueólogos e das posturas teóricas por eles adotadas em seus projetos de pesquisa, em outras palavras podemos dizer "que a comunicação do conhecimento produzido, por esses projetos científicos, está comprometendo e desfocando a imagem sobre a Arqueologia e distanciando-a do processo cultural contemporâneo" (BRUNO, 1995:18). Uma vez isto percebido se nota, enfaticamente, uma falha no chamado 'campo de projeção’3, já que o patrimônio advindo destas pesquisas arqueológicas não é enxergado pela sociedade que o circunda como uma herança, nem como uma constante na construção das suas identidades.

\footnotetext{
${ }^{3}$ BRUNO, Maria Cristina. Principais campos da ação museológica. Seminário CCBB: Museus e exposições no século XXI: vetores e desafios contemporâneos. Julho de 2004.
} 
Aliás, em alguns casos as coleções arqueológicas presentes em museus não são consideradas patrimônio arqueológico, isto porque para vários pesquisadores o conceito de patrimônio arqueológico está restrito ao que é encontrado nos sítios arqueológicos e que é, portanto, passível de escavação. Nossa idéia de patrimônio, implícito ai também a idéia de patrimônio arqueológico, é mais ampla. Envolve o fato de percebermos que artefatos, construções, saberes, fazeres e o ambiente se interconectam, de modo que podemos pensar em relações homem - artefato, natureza - homem, e assim sucessivamente.

Considerando que "as coleções arqueológicas estão na gênese da história dos museus" (BRUNO, 1996: 293) não há como estudá-las sem ter a noção de ambos os universos, o museal e o arqueológico. Contudo, no que concerne ao viés da arqueologia, há que se considerar que o estudo de acervos arqueológicos remete "a uma relação mais próxima entre a sociedade e o patrimônio cultural" (MARTINS \& BREDA, 2001/2002: 117). Tal relação existe basicamente desde os auspícios da ciência Arqueologia e, em muitos casos, serviu de lastro para a argumentação identitária de vários regimes políticos.

Vários autores já se debruçaram sobre a historicidade ou a respeito das noções que emanam do termo patrimônio (FUNARI \& PELEGRINI, 2006; CALI, 2005; LEMOS, 2004; JORGE, 2000; entre outros), entretanto, optamos por pensar e utilizar dois conceitos básicos que se interconectam: o primeiro deles é a noção de Patrimônio, formulada como "o conjunto dos bens, fruto das relações entre os homens e os recursos naturais; entre os homens em sociedade; e as interpretações que são elaboradas a partir destas relações" (BRUNO, 1999: 333); este conceito de patrimônio, entendido também como algo que demanda preservação, implica em entender também uma outra noção que é a de Herança, definida como "a consciência da existência desse Patrimônio, assumido enquanto conjunto de signos que permitem a identificação do indivíduo em relação a si mesmo e ao grupo a que pertence, no tempo e no espaço" (BRUNO, 1995: 159).

Os conceitos e problemáticas já apontados são reunidos em uma linha de estudo denominada de Musealização da Arqueologia, seguida neste trabalho e que entre outros aspectos comporta análises sobre mentalidades e também acerca do 
gerenciamento museológico das memórias que podem ser projetadas a partir de distintas realidades arqueológicas. Um campo de abordagem de natureza interdisciplinar, mas que apesar do nome não está circunscrito à relação Arqueologia - Museologia e comporta outras relações entre áreas de conhecimento, muito embora sua maior contribuição surja justamente da evidenciação de um olhar cúmplice, ou complementar, entre estas duas disciplinas, donde:

\begin{abstract}
"A Arqueologia evidencia facetas das sociedades, descobre peculiaridades de um passado às vezes esquecido e faz aflorar os indicadores da memória, mas não tem potencialidades efetivas de comunicar-se em larga escala com a sociedade presente. Já a Museologia se estrutura como área do conhecimento específica para viabilizar essa comunicação, mas depende, evidentemente, da produção de conhecimento próprio às áreas que estudam os indicadores da memória, como é o caso da arqueologia" (BRUNO, 1995: 142).
\end{abstract}

O estudo acerca da Musealização da Arqueologia preenche uma lacuna de análises porque se preocupa com aspectos pouco trabalhados por museólogos e praticamente esquecidos pelos arqueólogos, uma vez que "a estreita vinculação entre o desenvolvimento da pesquisa arqueológica e das instituições museais não tem sido uma preocupação dos arqueólogos” (BRUNO, 1995: 97).

A construção teórica e prática da Musealização da Arqueologia nos fez caminhar por três grupos de fontes que foram genericamente alinhados nos organogramas abaixo, bem como também nestes foi assinalado de onde provieram as informações para cada um destes grupos, ou as fontes propriamente ditas.

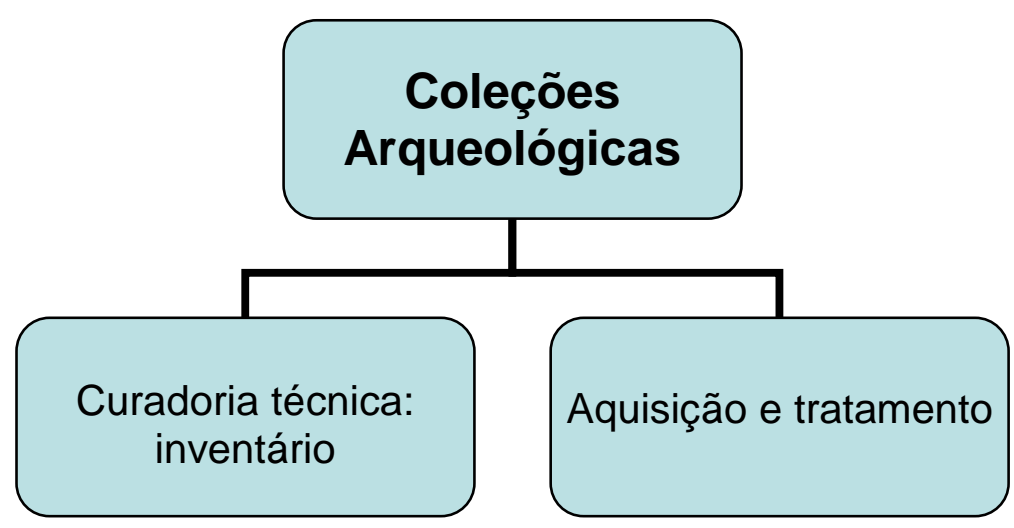



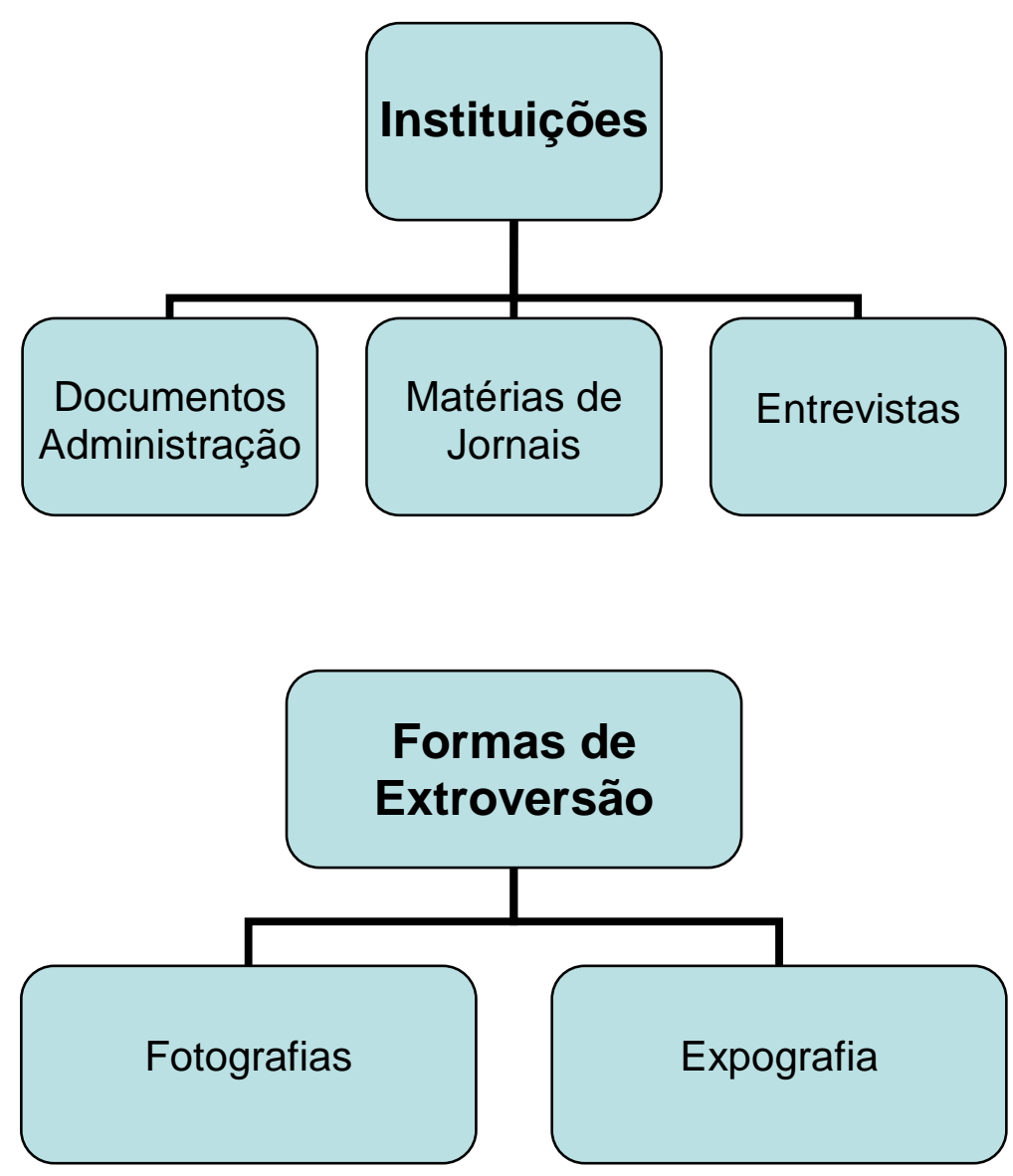

As coleções arqueológicas desses museus são compostas por instrumentos líticos (tanto polidos quanto lascados) e artefatos cerâmicos, ambos os tipos de vários matizes, por exemplo, no caso do lítico são pontas de projétil, lâminas de machados, tembetás, entre outros; já no caso dos objetos cerâmicos, além da variabilidade formal e de uso das vasilhas, ocorre também a presença de cachimbos cerâmicos. Houve diferença nas formas de aquisição dos artefatos que compõem estas coleções e, neste caso, o modo de aquisição implicou em diferentes formas de abordagem e gerenciamento dessas coleções.

Isto nos remete a um outro aspecto também válido e que pode fornecer importantes informações sobre os artefatos, trata-se da análise intrínseca das coleções arqueológicas visando à percepção de características, entre outras, como técnicas de execução, forma, função, dimensões e lugar de origem. Este último aspecto em particular embora não seja o foco deste estudo, tornou possível, por exemplo, posicionar os artefatos que compõem as coleções no âmbito do que se 
conhece em termos de arqueologia regional no Rio Grande do Norte. Esta etapa do processo ocorreu por meio de uma curadoria técnica tendo em vista a elaboração de inventários (figura 2) dos acervos arqueológicos ${ }^{4}$.

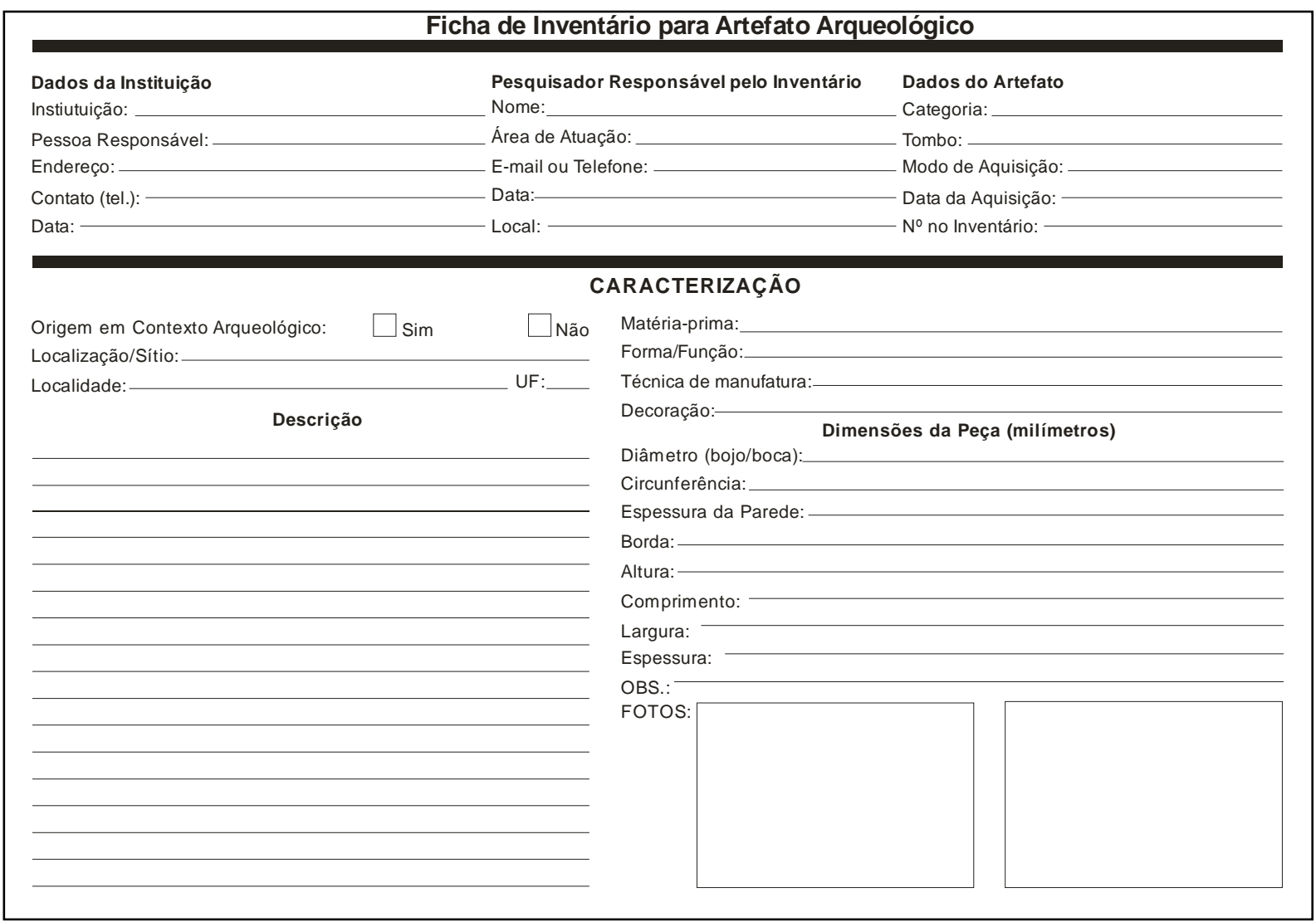

Figura 2. Modelo de ficha de inventário usado para as coleções arqueológicas dos museus Lauro da Escóssia, do Sertanejo, de Soledade e do Seridó.

Adentrar ao campo das memórias, visando uma melhor compreensão do patrimônio arqueológico "em seu contexto histórico e social" (FUNARI \& FERREIRA: 2003: 13), implica também na opção metodológica de analisar os diferentes discursos que entremeiam o trato com os materiais arqueológicos, sob o ponto de vista das Mentalidades ${ }^{5}$. As estruturas mentais são de longa duração, contudo, são

\footnotetext{
${ }^{4}$ Neste caso ocorre uma exceção no que diz respeito ao acervo arqueológico do Museu Câmara Cascudo, o único não inventariado durante esta pesquisa. Isto ocorreu por dois fatores básicos: primeiro a quantidade do acervo é muito ampla e o seu inventário suplantaria a temporalidade normalmente atribuída à consecução de um trabalho de mestrado, além disto, quando de minha etapa de trabalho no Câmara Cascudo o acervo arqueológico já estava sendo inventariado pela equipe de arqueologia desta instituição, ao fim do inventário se constatou a quantidade 53 mil peças. ${ }^{5}$ ARIÉS, Philippe. A história das mentalidades. In: LE GOFF, Jacques. A História Nova. 4.ed. São Paulo: Martins Fontes, 1988.
} 
passíveis de mudança. A evidenciação tanto da permanência, quanto da mudança nas atitudes mentais em relação aos bens arqueológicos pode ocorrer na medida em que transcorram as análises dos textos de jornais, dos relatórios internos dos museus, das atas de reuniões dos funcionários destas instituições, dos relatórios de pesquisa e das entrevistas procedidas.

A documentação oral, recolhida junto aos que lidam ou lidaram diretamente com os bens arqueológicos, foi analisada à luz da noção de que o processo que produz as lembranças, que leva à escolha dos acontecimentos a serem recordados, produz ao mesmo tempo o esquecimento de outras recordações. Isso porque toda lembrança é dotada de um caráter grupal, familiar e social e, assim sendo, se baseia em interesses do tempo presente de determinados grupos da sociedade (MOTTA, 1988:80), ou seja, entendendo que a memória é seletiva, atende a interesses e que também é dotada de diferentes níveis.

As coleções arqueológicas formadas nos museus universitários, nos museus municipais e também no caso do museu de Soledade são díspares em vários processos, dentre os quais, a título de exemplo, escolhemos a forma de aquisição, uma vez que esta é condição essencial para um bom manuseio do material e um melhor entendimento deste quando estiver em exposição. Quando os objetos foram adquiridos através da compra e da doação os conhecimentos sobre os artefatos são poucos, principalmente, no segundo, quando os objetos muitas vezes aparecem até sem o nome do doador. Já em casos onde grande parte da coleção foi adquirida usando métodos arqueológicos e, principalmente no caso do Câmara Cascudo, durante o que Prous ${ }^{6}$ chamou de "período recente" da pesquisa arqueológica brasileira, o conhecimento arqueológico não corresponde à realidade expográfica e evidenciam o fato de que

"nos processos de musealização da Arqueologia no Brasil, não só encontramos sintomas de antropofagia em relação aos indicadores da memória, mas identificamos os sinais da estratigrafia do abandono, construída ao longo do século $X X$, onde os museus representam a última camada" (BRUNO, 2005: 232).

\footnotetext{
${ }^{6}$ PROUS, André. Arqueologia Brasileira. Brasília: UNB, 1992.
} 
Assim sendo, inventariar coleções, assuntar pesquisadores e ou funcionários sobre as coleções arqueológicas, consultar a bibliografia advinda dos trabalhos de campo e de laboratório, percorrer salas de exposição, ler recortes de jornal sobre pesquisas arqueológicas e analisar documentações administrativas de instituições museológicas norte-rio-grandenses foi algo necessário tendo em vista alcançar os seguintes objetivos:

a) Pesquisar sobre os mecanismos de formação das coleções arqueológicas;

b) Compreender os bens arqueológicos como inseridos na interface Arqueologia-Museologia-História;

c) Estudar as formas de tratamento para com o patrimônio arqueológico nos museus já citados;

d) Analisar os discursos que permeiam os aspectos conjunturais dos lugares onde as coleções arqueológicas estão inseridas;

e) Relacionar a realidade arqueológica com o discurso expográfico, quando houver, e com a formação dos acervos arqueológicos no Rio Grande do Norte.

Os bens culturais, em nosso caso especificamente os bens arqueológicos pré-coloniais, que compõem nosso patrimônio são variados e representam vivências, memórias que quando exiladas têm a tendência de serem esquecidas e não trabalhadas, logo, não possuem representatividade, perdem a capacidade de significação. Uma vez que isto ocorra, observamos que o estudo da Musealização da Arqueologia no Rio Grande do Norte pode contribuir tanto no que diz respeito à inserção do patrimônio arqueológico em ambientes permeados por desenvolvimentos sócio-históricos particulares, quanto no que concerne ao fornecimento de informações sobre os pretéritos grupos humanos que habitaram o solo potiguar e como a herança destes grupos é percebida nos solos institucionais. 


\section{Os solos institucionais, ou, os capítulos que compõem esta Dissertação.}

Comecemos então pelo solo onde estão assentes as bases das relações entre a institucionalização da arqueologia brasileira e os museus brasileiros. $O$ capítulo 1 (Coleções, museus e identidades: elementos de uma relação entre patrimônio e arqueologia) é inicialmente uma visão sobre o hábito secular do colecionismo e de como em meio a situações específicas dos séculos XVIII e XIX ocorreram a formação e proliferação dos museus. Segue-se a isto uma abordagem historiográfica dos auspícios da arqueologia no país e de sua vinculação com três importantes instituições: o Museu Nacional, o Museu Paraense e o Museu Paulista. Lugares de origem da arqueologia institucional no país, ressalta-se o fato de que estas instituições tiveram uma forte vinculação com pesquisadores europeus e de que o "pensamento arqueológico" nestes espaços era antes de tudo um pensamento ligado as ciências naturais, como a zoologia e a botânica, por exemplo.

Destarte, se a criação de museus brasileiros no século XIX pode ser representada como um momento de implantação institucional da arqueologia, ou o nascimento desta ciência no país como alguns autores preferem dizer, ele também pode ser visto como um componente a mais no cenário que dá forma ao quadro de desprestígio das coleções arqueológicas em relação a outros elementos, ligados às ciências naturais ou a etnografia. Este quadro não se alterou muito mesmo com as mudanças de horizontes científicos ocorridas nas primeiras décadas do século $\mathrm{XX}$, o que

\footnotetext{
"se por um lado, aponta para um olhar ainda naturalista para os bens arqueológicos, ou mesmo capaz de confundi-los com objetos etnográficos, por outro lado, registra o papel de coadjuvante que as coleções referentes ao passado pré-colonial têm ocupado no cenário museológico nacional" (BRUNO, 1995: 113).
}

Há ainda no capítulo 1 uma discussão sobre patrimônios, ou patrimônios, esmiuçando termos como, por exemplo, patrimônio cultural e bem cultural. Conceitos mais amplos do que as definições mais setorizadas como, por exemplo, patrimônio arquitetônico. O capítulo finaliza abordando aspectos relativos às 
identidades e museus no nordeste do Brasil, temática importante em função das situações sócio-históricas observadas neste trabalho no que dizem respeito, principalmente, ao caso dos museus municipais.

Lugares de forte presença da administração pública, estes museus trazem à tona uma identidade regionalizada e local, valorizam aspectos do passado que estão firmemente atrelados em uma historiografia factual, usada na hora de se pensar a expografia destes espaços, e em meio a qual as fontes arqueológicas, apesar de serem expressivas e até conhecidas, ocupam diminuto espaço - isto quando não estão ausentes. É o caso, por exemplo, do museu de Mossoró que é abordado no capítulo 2 (Museu Histórico Lauro da Escóssia: estratos de uma coleção arqueológica no Oeste potiguar).

O Museu Histórico Lauro da Escóssia, de agora em diante também chamado de MHLE, é mais conhecido como museu de Mossoró e foi criado em 1948. O museu foi criado junto com uma biblioteca, ambos faziam parte de um projeto político cultural do então prefeito Jerônimo Dix-Sept Rosado Maia, 1948 1951 e da intelectualidade que o cercava. Biblioteca e museu tiveram seus espaços vinculados durante várias décadas e, quando por motivo de alguma reforma, houve uma separação entre estes ela ocorreu sempre em detrimento do museu. Este último, como todo órgão da municipalidade, está sujeito aos avanços e revezes da administração pública, tanto que as mudanças de gestores (prefeitos) do município sempre ocasionaram a mudança de espaço físico do museu ou uma alteração no quadro dos funcionários - inclusive a direção.

Essas mudanças repercutiram, por exemplo, na quantidade de peças que compõem o acervo do museu. Ou seja, uma mudança de prédio (ou de administração) implicava na perda ou desaparecimento de peças, por exemplo, da coleção arqueológica. Este nomadismo só foi terminado quando a partir das iniciativas do jornalista Lauro da Escóssia, diretor do museu entre o fim dos anos 1970 e início dos anos 1980, o museu foi transferido para o espaço que ocupa hoje: a antiga Casa de Câmara e Cadeia de Mossoró. Embora isto não signifique dizer que o poder público municipal passou a ter "outros olhos" para com o museu, rendeu 
ao Sr. Lauro da Escóssia uma homenagem - com o museu passando a ser chamado de Museu Histórico Lauro da Escóssia.

A administração municipal, principalmente a partir do final da década de 1990, dá o tom dos elementos sócio-históricos que devem ser valorizados ou rememorados enquanto parte da memória dos mossoroenses e que, neste caso, remetem diretamente a três eventos: 1) A abolição da escravidão, que de acordo com a historiografia local teria ocorrido em 30 de setembro de 1883, ou seja, primeiramente em Mossoró e somente cinco anos depois no Brasil como um todo; 2) A resistência ao bando de cangaceiro Lampião, em 13 de junho de 1927, fato constantemente lembrado pelos moradores locais como exemplo da força e resistência do povo desta cidade e 3) O $1^{\circ}$ voto feminino da América Latina, protagonizado pela professora Celina Guimarães em 1932.

O poder público municipal há muito propala tais acontecimentos e faz questão de reforçá-los, entre outros aspectos, por meio de grandes festividades anuais e pela nomeação de ruas que lembrem tal acontecimento. Daí porque, principalmente, a cultura material que evoque esses acontecimentos é muito procurada e valorizada em detrimento de outros acervos do Museu Histórico Lauro da Escóssia. Isto nos remete então à coleção arqueológica e ao fato de como estes artefatos são abordados no contexto desta instituição.

A coleção arqueológica do MHLE começou a ser formada desde 1949, é a mais antiga e uma das mais expressivas do estado. Os artefatos desta coleção computam aquisições advindas das mesorregiões Agreste, Central, Leste e Oeste do território potiguar. A coleção é composta basicamente por duas categorias de artefatos: líticos e cerâmicos. A grande maioria dos artefatos (cerca de 95\%) é constituída por líticos, lascados e polidos. O material polido pode ser agrupado nos seguintes conjuntos artefatuais: lâminas de machado, cunhas, cinzéis, mós, mãos de mó, almofarizes, pilões e batedores - esféricos e semi-esféricos. Nestes conjuntos sobressaem-se as lâminas de machado. No que diz respeito ainda ao material lítico polido, existe também na coleção algumas contas de colar e um tembetá (adorno labial). 
As matérias-primas de onde se originaram os artefatos polidos são: arenito, basalto, diabásio, granito e quartzo, sendo que o suporte básico em $70 \%$ dos casos é o granito, rocha dominante nas regiões central e oeste do Rio Grande do Norte. No que concerne aos líticos lascados, há no Museu Histórico Lauro da Escóssia a maior coleção de pontas de projéteis do estado. De fato, a menor quantidade de peças na coleção arqueológica do MHLE fica por conta das cerâmicas, são cinco cachimbos, ou mais precisamente cinco fornilhos de cachimbo que apresentam decoração incisa e excisa, havendo em um dos artefatos a elaboração de motivos geométricos em uma das superfícies. Entre os 22 municípios tidos como lugar de origem das peças, as localidades que mais contribuíram com materiais para esta coleção, curiosamente são as menos pesquisadas até hoje, diga-se de passagem, que a grandeza do potencial do estado para materiais arqueológicos é inversamente proporcional à quantidade de pesquisas já executadas.

Percebe-se que o princípio de pesquisar os materiais para depois expôlos, adotado pelos primeiros museus brasileiros e no Rio Grande do Norte pelo Museu Câmara Cascudo, durante o período em que funcionava o Departamento de Antropologia desta instituição, não condiz com a realidade do Museu Histórico Lauro da Escóssia. Dessa forma, não só a exposição, mas também o trato com os materiais arqueológicos neste museu apresentam especificidades que, de uma forma mais direta, podem ser representadas por uma forte vinculação que, dentro desse contexto, eles assumiram em relação à produção historiográfica local, principalmente, por se tratarem de artefatos relacionados aos grupos ágrafos norterio-grandenses.

A produção historiográfica sobre o Rio Grande do Norte foi desde os primeiros trabalhos fortemente influenciada por uma concepção tradicional de história, algo comum aos estudos históricos brasileiros na primeira metade do século $X X$, essa concepção reforçou a idéia de um passado brasileiro homogêneo e em meio ao qual se distinguem referências patrimoniais como, por exemplo, igrejas ou casas grande, em detrimento, entre outros, dos bens indígenas. 
O exame da historiografia norte-rio-grandense evidencia uma mesma tendência manifesta em obras que buscam sintetizar a história do país, a ausência de itens ou capítulos que se dediquem à ocupação pré-histórica do Brasil. Isto tanto para os autores ditos clássicos, que escreveram "obras de visão geral sobre a história do Rio Grande do Norte, escritas na primeira metade do século XX" (MONTEIRO, 2002: 15), quanto para os pesquisadores mais novos, responsáveis "por obras que tratam de temas específicos, produzidas mais recentemente" (MONTEIRO, 2002:15).

Apesar da pré-história norte-rio-grandense não haver sido incluída nas sínteses históricas até então produzidas no estado, é possível observar que houve e há uma produção acadêmica na área de arqueologia direcionada ao entendimento dos grupos humanos ágrafos deste espaço e que poderia ser utilizada como suporte na hora de se pensar a cadeia operatória de procedimentos museológicos no âmbito do Museu Histórico Lauro da Escóssia, contribuindo para uma valoração dos elementos nativos do estado e da região Oeste principalmente. Esta produção acadêmica, aliás, nos remte a outra instituição abordada no capítulo 3 (Arqueografia dos estudos em pré-história e arqueologia e a transposição expográfica destes estudos) desta dissertação.

Em dezembro de 1961 foi fundado o Instituto de Antropologia da Universidade do Rio Grande do Norte e no ano seguinte a universidade foi federalizada, vindo o Instituto de Antropologia a ser transformado no Museu Câmara Cascudo, de agora em diante também chamado de MCC, por volta de onze anos depois disto ter acontecido ${ }^{7}$. O fato de o instituto ter se tornado um museu reflete não só um momento de favorecimento político-institucional da universidade, já que esta mudança significaria o aumento no envio de verbas para esta última, mas reflete também preocupações da parte dos administradores e professores do instituto no que tange a necessidade de espaços mais amplos para o

\footnotetext{
${ }^{7} \mathrm{Na}$ "Ata da 39a Reunião Extraordinária da Congregação de Professores do Instituto de Antropologia da Universidade Federal do Rio Grande do Norte", realizada em 05/10/1973, é dado ciência ao quadro docente da instituição "ter o Magnífico Reitor, conseguido junto às autoridades do MEC, a mudança do no Instituto de Antropologia para Museu (de Antropologia) Câmara Cascudo, medida essa que colocava o I. A. nas mesmas condições do Museu Goeldi e do Museu Nacional do Rio de Janeiro, acrescentando o Diretor ser essa medida de incalculável valor e importância, uma vez que o mesmo poderá abrigar, de agora em diante, todos os campos da pesquisa".
} 
acondicionamento dos acervos que estavam sendo formados, bem como, de uma área destinada à exposição de parte deste material.

A ampliação constante nos acervos do Museu Câmara Cascudo pode ser atribuída em grande parte à forte atuação do Departamento de Arqueologia desta instituição. Criado em 1961 e com pesquisas desenvolvidas desde 1962, este departamento é lembrado nacional e internacionalmente até os dias de hoje. Chegando a aglutinar nos anos 1980 uma equipe de arqueologia com 4 arqueólogos - fato raro nos dias atuais, quem diria há quase trinta anos -, este departamento empreendeu pesquisas pontuais em praticamente todas as regiões do estado. Destes trabalhos resultaram publicações feitas em periódicos nacionais, internacionais e, também, algumas separatas financiadas com recursos dos próprios pesquisadores ou do Museu Câmara Cascudo.

Estes mais de 25 trabalhos publicados de 1965 até 1992 representam grande parte do se produziu em termos de arqueologia acadêmica no Rio Grande do Norte. Aliás, nisto o Museu Histórico Lauro da Escóssia é diametralmente oposto ao que foi observado no Câmara Cascudo, ou seja, 98\% do acervo de arqueologia brasileira deste último foi formado a partir dos materiais coletados nas pesquisas de campo levadas a cabo por pesquisadores da instituição.

Este é um dado que deveria refletir não só um maior controle sobre o acervo, mas também a geração de uma documentação e a presença de profissionais que poderiam contribuir para que a coleção arqueológica ocupasse um espaço mais expressivo, isto quando em comparação com a forma como os artefatos arqueológicos são observados em outros museus do estado.

Deveria, não significa que foi. Isto porque na prática, apesar de ser um museu universitário e congregar profissionais, por exemplo, da museologia e da arqueologia, as fontes arqueológicas no MCC estão tão exiladas quanto em outros espaços museais onde há bens arqueológicos. Ou seja, não possuem nesta assim como em outras instituições a menor articulação com outros conjuntos patrimoniais. Mormente, o que se observa, aliás, é que, talvez por ser a capital do estado, a exposição no Museu Câmara Cascudo tenta ser mais plural e enaltecer o potencial econômico e os valores regionais do estado. 
Esta exposição permanente foi criada no início dos anos 1980 e de lá para cá sofreu algumas intervenções, como salas que foram criadas. Apesar de ser um projeto de vanguarda quando foi elaborado, nesta exposição transparecem algumas características de favorecimento a determinados setores do museu, como no caso da Botânica e da Geologia - setores politicamente mais fortes na instituição quando a exposição foi elaborada -, e em contrapartida um desfavorecimento, isto levando-se em conta a produção científica do museu, as fontes arqueológicas que estão em grande quantidade na reserva técnica e de maneira quase inexpressiva na exposição. Na seção dedicada à arqueologia, inclusive, há aspectos mais ligados à pré-história das regiões sudeste e que não são conhecidos em termos de realidade arqueológica no Rio Grande do Norte.

Esta situação inclusive, nos faz perceber que o museu em alguns casos "suprime o tempo e a presença de agentes da História" (FUNARI, 1995: 37). Neste caso, se percebe que a produção acadêmica na área de arqueologia do próprio museu não serviu de base para o processo de comunicação museológica pensado para a expografia no Câmara Cascudo. Isto, em um plano local, nos remete a considerar que

"os estudos arqueológicos, embora voltados para a identificação e compreensão das continuidades e mudanças dos processos culturais das sociedades nativas, nas suas mais diferentes características, raramente são considerados como fontes para a interpretação desta nação" (BRUNO, 1995: 7).

A produção acadêmica em arqueologia do Câmara Cascudo, talvez, não tenha sido levada em consideração devido a disputas internas na instituição. Contudo, isto não obnubila o fato de que tal qual em outros lugares os bens arqueológicos não são articulados enquanto parte do patrimônio cultural. Os artefatos arqueológicos no Câmara Cascudo estão por incrível que pareça descontextualizados e compõem um quebra-cabeça onde faltam peças, ou seja, não se articulam com outras memórias. Isto é algo recorrente no espaço dos museus estudados, com uma exceção que é a do Museu de Soledade, abordado no capítulo 4 (Da Fundação Amigos do Lajedo de Soledade ao museu universitário: outros 
aspectos da Musealização da Arqueologia no Rio Grande do Norte), junto com duas outras instituições.

Na cidade de Apodi, município da região Oeste do Rio Grande do Norte há um povoado conhecido como Soledade. O lugar era até o início dos anos 1990 um espaço de extração da cal. O que mudou? A percepção dos moradores do lugar. E os moradores do lugar passaram a cuidar do espaço que em fins do século XVIII o padre Francisco Correia Teles de Menezes chamou de "Lages da Soledade"8. O que despertou a atenção do padre? A mesma coisa que hoje é valorizada pelos moradores de Soledade, as pinturas rupestres.

O sítio arqueológico do Lajedo de Soledade apesar de noticiado no século XVIII só veio a ser conhecido arqueologicamente no início dos anos 1980, através de trabalhos do professor Tom Miller que propôs um programa de pesquisas arqueológicas para área e que na época não obteve financiamento. Ainda no final dos anos 1980 Tom Miller apontava a importância do sítio e ressaltava a necessidade de preservação da área, objeto de destruição avançada por causa da exploração da cal.

Nos anos 1990, mais precisamente em 1992, o Laboratório de Arqueologia da Universidade Federal do Rio Grande do Norte e o Departamento de Paelontologia do Museu Câmara Cascudo empreenderam pesquisas na área, sob o financiamento da Petrobrás. Os moradores de Soledade se organizaram em torno de uma associação, a Fundação Amigos do Lajedo de Soledade - de sigla FALS -, e com o apoio da estatal brasileira elaboraram uma espécie de centro turístico onde o principal vetor de recursos é o par formado pelo sítio arqueológico e uma construção nas imediações do sítio, o Museu de Soledade. Este museu foi elaborado em parceria com a UFRN e a montagem da exposição buscou refletir os resultados advindos das pesquisas realizadas naquele sítio, dando a este museu um padrão diferente em relação a outros no estado.

O caso do Lajedo de Soledade poderia ser tomado como referência, ou modelo, para uma outra importante área arqueológica do Rio Grande do Norte: o

\footnotetext{
${ }^{8}$ Uma reprodução das referências feitas pelo padre Teles de Menezes sobre o Lajedo de Soledade e outros sítios arqueológicos do RN pode ser encontrada na obra: BASTANI, Tanus Jorge. Minas e Minérios no Brasil: tesouros, cidades pré-históricas e minas abandonadas, 1957. Série B, n. 999, 1991. (Coleção Mossoroense).
} 
Seridó. Nesta região existem os museus do Sertanejo em Acari e do Seridó em Caicó, outras duas instituições que tiveram seu envolvimento com a Musealização da Arqueologia também analisados neste trabalho. Por que justamente estes museus foram escolhidos? Justamente pelo fato de que os municípios onde essas instituições se localizam fazem parte da região do estado com o maior número de pesquisas arqueológicas já feitas e que, de uma maneira a contrastar com a intensa quantidade de acervo gerada em tais trabalhos, as coleções do Museu do Sertanejo e do Museu do Seridó juntas alcançam pouco mais de duas dezenas de artefatos. Além disso, a existência da Fundação Seridó poderia significar, de maneira semelhante à FALS, a existência de uma instituição para a captação de recursos e gerenciamento junto com as comunidades da região do patrimônio arqueológico, que poderia então neste caso ser parcialmente musealizado em municípios do Seridó norte-rio-grandense.

A área arqueológica do Seridó é pesquisada por integrantes do Núcleo de Estudos Arqueológicos da Universidade Federal de Pernambuco desde os anos 1980. A título de exemplo citamos o fato de que em apenas um sítio, do tipo abrigo sob rocha e escavado parcialmente, foram coletados 27 enterramentos. O acervo não é gerenciado por instituições norte-rio-grandenses e informações relacionadas aos grupos humanos pré-históricos da região que poderiam ser abordadas em museus seridoenses não o são. Podemos neste caso dizer que "os estudos arqueológicos, responsáveis pela fidedignidade atribuída aos vestígios dessas populações, têm construído um rico e multifacetado universo patrimonial, ainda imperceptível" (BRUNO, 1995: XVI).

Exilar, isolar, manter-se longe de algo, exiladas estão as coleções arqueológicas nos museus Câmara Cascudo e Lauro da Escóssia. Apesar de ocuparem o mesmo espaço, os artefatos que compõem os acervos arqueológicos destes museus estão longe de outros conjuntos patrimoniais sob a mesma responsabilidade institucional. Apesar da existência de lugares de memória em Acari e Caicó, isoladas, exiladas estão as memórias dos grupos que habitaram o que hoje é a região Seridó do Rio Grande do Norte em tempos pré-coloniais. Nos resta então 
um caminho, uma instituição onde a Musealização da Arqueologia tomou um rumo diferente, mas não foi só este o único motivo que me levou a escrever esta dissertação. 


\section{CAPÍTULO I}

Coleções, museus e identidades: elementos de uma relação entre patrimônio e arqueologia. 
A 'visualização do passado' não é restrita a uma relação pessoal com os objetos através do que Stephen Bann chamou de "valor de época" (BANN, 1994: 166 - 167), é também uma forma contínua de acumulação e ordenação de objetos em espaços físicos. Assim, podemos nos remeter a um caminhar lento e gradual do qual a formação dos museus, enquanto instituições mantenedoras de uma memória patrimonial, não pode ser dissociada. Neste sentido, cumpre ressaltar também que

\begin{abstract}
"ao lidar com artefatos de coleções museológicas é necessário, por outro lado, ter em vista que eles não são meros objetos ilustrativos de uma cultura exótica, de um passado remoto e saudosista, ou espécimes bizarros ou curiosos. Enfoques teóricos, com os quais compartilho, procuram conferir aos objetos de museus o "status" de documento" (BARCELOS NETO, 1999: 241).
\end{abstract}

Contudo, as nuances deste processo vicejam pormenores como noções de temporalidade e valor, as quais o espaço europeu e, mais especificamente de países como a Itália e a França, este último de forma mais marcante, buscaram delimitar durante os séculos XVIII e XIX. Neste contexto, notamos que as próprias idéias de tempo e de significado, entendido aqui como valor, tornaram-se passíveis de discussões, pois, quando tomamos suas definições o mais estritamente possível percebe-se

"que se destacam, essencialmente, duas noções de temporalidade: aquela do tempo que irremediavelmente escoa e, uma outra, do tempo que dura (...) isto é, uma projeção do futuro ou, diferentemente, uma volta ao passado" (BREFE, 1998: 282).

Na mesma medida o significado dos monumentos, ou objetos, pode ser notado

"em relação a três critérios separados: seu 'valor artístico', seu 'valor histórico' e seu 'valor de época'. Dos dois primeiros, pouco precisa ser dito, exceto que eles correspondem a diferentes modos de materializar e distanciar o 'monumento', seja por dar a ele um certificado de excelência atemporal, seja por atestar a relevância para uma determinada seqüência de eventos passados. Mas 'valor de época' é bem diferente. Trata-se de uma propriedade perceptível 
do edifício (ou objeto) que dificilmente é mediada (...) por algum conhecimento especial de arte ou historia" (BANN, 1994: 156).

Voltar ao passado por meio de um objeto que denota o seu valor histórico, travestiu-se, para alguns colecionadores, de uma visão do passado por um apego, um valor de época associado a um objeto. Neste sentido, apesar de ser possível se projetar o futuro distanciando-se do passado, uma vez que este já se encontra materializado, não é possível deixar de aquiescer a este conceito criado no século XIX e que representa uma atitude de vinculação ao objeto que, não necessariamente, carece ser revestida por um saber de ordem teórica.

Valorizar um dado objeto não por suas propriedades explicitas, ou intrínsecas, mas sim, por sua significância e possibilidade de visualizar o passado é algo observado como sendo a mesma "atitude antiquária" descrita por Nietzche. Foi justamente esta atitude antiquária para com os objetos, impingindo-lhes atributos afetivos, que formulou uma idéia mítica de possibilidade de ressurreição do passado por intermédio do processo de recuperação histórica ou arqueológica destes.

"Mas é claro que os antiquários não simplesmente juntam objetos e oferecem aos motes para contadores de Historia populares. Até Bryan Faussett cuidou de arrumar seus estimados objetos na forma de um pavilhão, onde cada relíquia e inscrição teria contribuído para um efeito global que era mais do que a soma de suas partes" (BANN, 1994: 196).

\section{Da 'ressurreição do passado' em coleções à formação dos museus, passando pelo exótico dos gabinetes de curiosidades.}

$\mathrm{O}$ ato de colecionar não pode ser apregoado como tendo seu início restrito ao período renascentista, pois, na prática, a atitude de colecionador precede esta época e remonta, inclusive, à Antigüidade. Tratava-se da aglutinação de objetos, autênticos tesouros, que eram egressos de achados fortuitos, compras ou espólios de guerra. Contudo, tal atitude não era dotada do caráter de voracidade com que algumas coleções foram montadas na Idade Moderna e, principalmente, na contemporaneidade, quando, por exemplo, integrantes da classe média vitoriana 
enxergavam "no ato de colecionar (...) um emblema do individualismo triunfante" (GAY, 2001: 158).

$\mathrm{Na}$ realidade, antes de ser um hábito permissível à classe média, o colecionismo foi característico de uma nobreza que contribuiu justamente ao longo do Renascimento europeu (séculos XIV a XVII) para a formação dos 'Gabinetes de Curiosidades', lugares onde

"a côte dês antiquités et des pièces historiques, ils rassemblent de nouveaux types d'objets: curiosités naturelles, ou artificielles, raretés exotiques. Fossiles, coraux, "pétrifications", fleurs ou fruits venus des mondes lointains, animaux monstrueux ou fabuleux, objets virtuoses d'orfèvrerie ou de joaillerie, pièces ethnographiques ramenées par les voyageurs, toutes les bizarreries de la création sont réunies, pour que le collectionneur ait à portée du regard ce qui vient desconfins du monde connu, et à quoi il attribue souvent des pouvoirs magiques“" (SCHAER, 2000: 21 - 23)

Pormenorizando as situações dos gabinetes de curiosidades, observamos que nem todos tinham esta dimensão enciclopédica, ou mesmo cosmológica, alguns possuíam um viés mais voltado para as ciências naturais, ou para a História Natural, e se reportavam ao estudo de plantas, minerais e de animais, com finalidades medicinais e farmacêuticas. De maneira geral, podemos dizer que os gabinetes de curiosidades "préfigurent les grands développements des sciences naturelles au XVIII ${ }^{e}$ siècle“" (SCHAER, 2000: 26).

Aliás, esta mesma história natural é a responsável por incipientes práticas de classificação dos objetos colecionados, seriando-os com o fito de ordenar racionalmente o mundo. Assim sendo, quando caminhava-se para os últimos decênios do século XVII notou-se certos apelos, ou usos, científicos e pedagógicos dos ditos gabinetes de curiosidades impondo

"uma ruptura com a 'cultura da curiosidade' e com sua disposição aparentemente caótica dos objetos, em proveito de uma nova ordem das coisas que acompanha a especialização dos saberes. Não apenas as coleções de objetos da natureza passam a ser ordenados segundo uma reconstituição sem lacunas da grande cadeia dos seres, pela comparação e classificação das espécies, mas também se impõe, pouco a pouco, às coleções artísticas uma nova apresentação, especializada e histórica" (BREFE, 1998: 296) 
Assim, podemos notar que estudar os museus é também estudar essa relação dos homens com os artefatos, que no passado está muito ligada ao fenômeno do colecionismo, mas que nos dias da contemporaneidade têm os museus como espaço privilegiado desta relação. Sem o entendimento de que o colecionismo representa uma etapa no desenvolvimento da relação homens artefatos, ficaria vedada a possibilidade de observação do sentido amplo que implica a visualização de uma obra, notada a partir do viés de valorização do que a observação direta desta tem a oferecer no concernente à apreensão de suas características e da conseqüente atribuição de seu valor de época. Dessa forma é que "a idéia de museu aparece como espaço de exposição pública que reúne, dá visibilidade e permite acesso direto às obras" (BREFE, 1998: 286).

Sob vários aspectos é possível perceber que esta empreitada iniciada nos últimos decênios do século XVIII demandava para uma melhor eficácia do templo da memória uma adaptação dos lugares para receber as coleções que, sobretudo naquele momento, eram em sua maioria pertencentes à realeza. Estas adaptações teriam como elementos essenciais itens como: a segurança das obras "e o aspecto físico e ambiental de conjunto, já que eu afirmaria sem receio que a recriação histórica implica atenção particular a aspectos tais como a iluminação geral do espaço" (BANN, 1994: 167). Além disso, temos o "aparecimento de uma legislação de proteção do patrimônio artístico, concebido como elemento fundador de uma identidade coletiva" (POMMIER Apud BREFE, 1998: 296).

Bom, parece que sem estes esforços físicos, ambientais e jurídicos, como também sem as buscas por uma mudança do privado para o público no que diz respeito à visualização das obras e, na mesma medida, sem a procura por uma cientificidade no que tange ao exercício de elaboração e aplicação de conceitos (todos esforços corroborados no século XVIII), o século XIX jamais teria se tornado o século dos museus. Algo que ainda pode ser acrescentado a estes preceitos relacionados com o museu e que, mesmo surgido no século XVIII, não mudou durante o século $\mathrm{XIX}$, foi que

"sob a inspiração na mítica 'biblioteca museu' dos ptolomaicos em Alexandria e sob os auspícios das musas, filhas da memória, dois 
aspectos da instituição são postos em destaque: 'lugar ideal de ensino e de pesquisas fundadas em textos e em instrumentos científicos, mas também lugar de memória composto com os retratos daqueles que se distinguiram nas atividades do espírito'" (BREFE, 1998: 298).

Desta feita, os museus pretendiam e, em alguns casos até hoje pretendem, dar relevo a uma espécie de memória didática iconizante, pois, mesmo prestando-se às benesses da ação pedagógica ainda assim mantinham-se como divulgadores de um passado em certa medida mítico e em sua essência também iconizante. Esta mitificação advém justamente do papel político que o museu enquanto instituição tende a passar, daí porque em lugares como na França, posterior à Revolução de 1789, irá surgir, em meio às contradições do cenário político, uma concepção de tempo diferenciada das antigas pelo fato de estar imbricada nesta a idéia de progresso.

"É a introdução da idéia de progresso que causa uma desorientação na antiga ordem do tempo e em sua representação - história "magistra vitae" - impondo um (sic) nova forma de pensá-la, ao mesmo tempo como continuidade e ruptura. A representação do passado se fará, então, de duas formas: A história e a memória" (BREFE, 1998: 305).

A mesma França de governo revolucionário que fomenta esta idéia de progresso é a que legitima, também, o espaço do museu como um compêndio de conservação, estudo e produção de conhecimento, tarefas que demandaram métodos e técnicas aglutinados no que podemos caracterizar como museologia 9 .

\footnotetext{
9 “Uma análise da discussão museológica dentro e fora do ICOFOM nos dá a seguinte diversidade de opiniões:

a - A museologia como o estudo e da finalidade e organização dos museus;

b - A museologia como o estudo da implementação e integração de um certo conjunto de atividades, visando à preservação e uso da herança cultural e natural:

1. dentro da instituição museu

2. independente de qualquer instituição

c - A museologia como o estudo:

1. dos objetos museológicos

2. da musealidade como uma qualidade distintiva dos objetos de museu.

d - A museologia como o estudo de uma relação específica entre homem e realidade.

Essa tipologia nada mais é do que um esboço, a grosso modo, das principais orientações encontradas na literatura sobre museologia" (MENSCH, 1994: 3).
} 
Talvez por isto, é que se possa hoje ter ciência da relação de mediação desempenhada pelo museu, no que diz respeito à relação com os objetos, pois

"as várias transformações de que o museu foi alvo ao longo deste século, sua multiplicação em diversos países do mundo e, principalmente, a abrangência praticamente ilimitada de objetos que engloba indicam que ele é um dos lugares-chave para se entender as sociedades modernas e a forma pela qual elas se fazem representar" (BREFE, 1998: 315).

Podemos dizer que esta percepção do museu enquanto espaço de mediação, ou lugar de memória, e a formulação desta noção de progresso, evidenciada também nos objetos/artefatos, contribuíram para que a arqueologia viesse a dar sustento ao postulado sobre o progresso humano, na medida em que a descoberta em solo europeu de artefatos de pedra como antecessores de objetos feitos de ferro deu margem a estudos, ou inferências, acerca do desenvolvimento das sociedades humanas. Os estudos nestes casos são voltados para os objetos em si, sem uma preocupação contextual, e pensando em um desenvolvimento humano linear.

$\mathrm{Na}$ esteira destes acontecimentos, observamos que o final do século XVIII testemunhou ainda a criação de alguns museus etnográficos, enquanto instituições voltadas para colecionar, exibir, preservar, estudar e interpretar objetos da chamada cultura material. Este motivo contribuiu sem dúvida para que as instituições criadas naquele momento atuassem como abrigos de uma ciência antropológica em sua fase inicial.

Sob estes augúrios, embora ainda não propriamente antropológicos, é que surgiram o 'British Museum', a 'Royal Society' de Londres e a 'London Society of Antiquaries', esta última foi responsável pela elaboração de uma publicação sistemática, sob a forma de um jornal anual chamado de 'Archaeologia', editado a partir de 1770. Entretanto, a partir da década de 1830 viu-se uma autentica proliferação de museus e sociedades de estudo.

"A bibliografia especializada sobre a história dos museus ainda não dedicou muitos títulos à análise da inserção da arqueologia nestas 
instituições. Entretanto, é possível identificar que as primeiras coleções de antiguidades foram, mais tarde, contribuir para o crescimento e proliferação dos museus de Arte. Enquanto que as coleções arqueológicas relacionadas a períodos mais recuados foram integradas aos museus de História Natural ou aos Museus de Antropologia" (BRUNO, 1996: 301).

Destacam-se em meio a este movimento o Museu Etnográfico de Ciências de São Petersburgo, fundado em 1836; o 'National Museum of Ethnology' de Leiden, 1837 e o 'Peabody Museum of Archaeology and Ethnology', criado em 1866.

\begin{abstract}
"A partir de então dois modelos diversos serão seguidos. Alguns se basearão nos padrões de Peabody, concentrando-se preferencialmente na pré-história, arqueologia e etnologia. Outros, principalmente os museus da Europa continental, se constituirão em centros de cultura nacional e popular" (STOCKING JR. Apud SCHWARCZ, 1993: 68).
\end{abstract}

Destarte, torna-se premente observar como estas idéias foram percebidas no Brasil bem como entender a relação, ou relações, formada(s) entre os museus brasileiros e as ciências humanas, mais especificamente, a arqueologia, como também perceber a vinculação dos pesquisadores brasileiros com teorias como o Poligenismo e o Evolucionismo, tão em voga naquele momento.

\title{
Os museus brasileiros, sua relação com os auspícios da Arqueologia no país e sobre a relação desta com a Museologia. ${ }^{10}$
}

\author{
"o Brasil surgiu no cenário \\ museológico internacional no \\ século XIX, durante o período \\ áureo destas instituições, em um \\ momento de grande impulso das \\ Ciências Naturais" (BRUNO, \\ 1999a: 74).
}

\footnotetext{
${ }^{10}$ O pequeno ensaio neste capítulo sobre os museus brasileiros e sua relação com os auspícios da arqueologia visa apenas situar o leitor em meio ao contexto em que ocorreu a formação, em museus brasileiros, das primeiras coleções arqueológicas. Isto porque entendemos que foge ao escopo do presente trabalho historicizar toda esta relação ao longo dos séculos XIX, XX e início do século XXI.
} 
Durante muito tempo a ciência que se fez no Brasil era executada apenas pelos homens que caminhavam no país perscrutando através de seus intérpretes, pois eram em sua grande maioria estrangeiros, sobre a fauna, a flora e demais informações "científicas" a respeito das terras que eles avistavam. Sob o beneplácito real o Brasil tornou-se o país dos naturalistas, ou dos viajantes

"em busca de espécimes para as suas coleções. A palavra de ordem era salvar o que mais se pudesse, uma vez que imperava a idéia de que essas culturas se extinguiriam, estando os 'vestígios' mais bem preservados nos museus metropolitanos" (SCHWARCZ, 1993: 69).

Para a ciência arqueológica este também pode ser denominado de "Período Especulativo" (ROBRAHN-GONZÁLES, 2000: 13) ou "período exploratório, vinculado às missões dos naturalistas viajantes" (SOUZA, 1991: 11).

Ao longo de boa parte do século XIX o Brasil não possuiu recursos e muito menos instituições para dar cabo de empreitadas científicas. Apesar disto, tal fato não impediu que ao longo da administração de D. João VI (1808-1821) ocorresse a criação: da Escola de Cirurgia da Bahia, da academia dos GuardasMarinha, da Imprensa Régia, da Biblioteca Nacional, das Academias MédicoCirúrgica e Militar, de um Horto Botânico e de um Museu Real, no Rio de Janeiro.

Contudo, podemos dizer que a pesquisa científica no Brasil só 'decolou' a partir da década de 1870 devido ao ingresso no país de novos modelos científicos e, também, por meio de uma continuação da formação de instituições congêneres ao Museu Real, rebatizado com o advento da República para Museu Nacional.

\footnotetext{
"Evolucionismo, positivismo, e naturalismo começaram a penetrar o país a partir dos anos 1870. Paralelamente, uma elite intelectual brasileira começou a se organizar em torno do debate romântico sobre os fundamentos de uma 'cultura nacional'. A criação de museus locais, brasileiros, veio de certa forma refletir estes novos ideais contrapondo-se aos legados metropolitanos e à ótica colonial" (SCHWARCZ Apud BARRETO, 2000: 37).
}

Não bastasse isto, cabe ressaltar ainda que "a perspectiva colonial, do europeu branco explorando um passado exótico e distante, predominou até a 
institucionalização da arqueologia dentro dos museus e centros de pesquisa científica, a partir do século XIX" (BARRETO, 2000: 33).

A partir destas novas idéias é que temos o século XIX também conhecido no Brasil como a "Era dos Museus" (LOPES, 1995: 12). Tendo como principal meio de sustentação uma vinculação com a história natural, o saber formado nestes centros de pesquisa pautava-se em exemplos europeus tanto na práxis científica, onde quem ditou as regras durante muito tempo foram os estrangeiros, quanto na forma de divulgação de seus trabalhos, visto que as revistas, arquivos ou boletins destes museus pareciam muito mais uma forma de relacionar-se com os museus estrangeiros do que espaços para discussão e propagação das pesquisas brasileiras.

"Os museus brasileiros entraram neste século, com coleções arqueológicas provenientes de coletas assistemáticas, como locais de ensino e produção científica, como depósito de objetos ordenados, atuando a partir de uma perspectiva enciclopédica, evolucionista e classificatória" (BRUNO, 1999a: 82).

Apesar disto, o Museu Nacional - Rio de Janeiro, o Museu Paraense Emílio Goeldi - Belém e o Museu Paulista - São Paulo, contribuíram para a sedimentação no país de várias ciências e, principalmente, daquelas como a etnologia, a antropologia e a arqueologia, as quais estavam dando seus 'primeiros passos'.

"O papel destes novos museus (...) foi decisivo para 0 desenvolvimento da arqueologia no país, não só na forma como a pesquisa foi institucionalizada mas também ao definir os modelos científicos de produção do conhecimento. Neles, antes de mais nada, a arqueologia e a etnologia ganharam espaços próprios, apesar de secundários em relação à botânica, à zoologia, e à geologia, enfim, às 'verdadeiras' ciências naturais" (BARRETO, 2000: 38). 


\section{$\underline{\text { O Museu Real ou Museu Nacional }}$}

Mantendo sob sua tutela alguns materiais advindos da chamada "Casa dos Pássaros", onde de 1784 à 1813 "se colecionou, armazenou e preparou produtos naturais e adornos indígenas para enviar a Lisboa" (LOPES, 1995: 26), o Museu Real foi criado em 06 de junho de 1818 após o que foram viabilizados os espaços físicos para a instituição. Erguido com o objetivo de ser um compêndio para produtos naturais de todo mundo, o museu do Rio de Janeiro nasceu com o fito de tornar-se de "caráter metropolitano e universal" (LOPES, 1995: 46), muito embora, sob o ponto de vista prático, parece ter faltado a este museu em seus primeiros decênios recursos financeiros e conquistas científicas, sem as quais o intento de padronizar-se tal qual uma instituição estrangeira veio a ser prejudicado.

A década de 1870 aparece para o Museu Nacional como propiciadora de bons tempos, principalmente, a partir da administração de Ladislau Netto, 18751893. Nesta época

\footnotetext{
"a seção de 'Anthropologia, zoologia geral e applicada e paleontologia animal' abarcaria também a arqueologia, contando inclusive com um primeiro arqueólogo nos quadros do museu, Ladislau Netto. Tendo em vista a produção do Museu Nacional na área de antropologia fortemente influenciada pela direção de J.P. Lacerda, a disciplina era praticada essencialmente como antropologia biológica, como exemplificam os vários estudos de craniometria e traços indígena publicados pela revista do museu" (LOPES \& SCHWARCZ Apud BARRETO, 2000: 38).
}

Aliás, a própria revista deste museu, intitulada Archivos do Museu Nacional, foi criada durante a década de 1870 para tornar viável a permuta de materiais bibliográficos com instituições museológicas fora do Brasil, fazendo parte de um esforço para colocar o Museu Nacional nos moldes europeus. Como prova disto, percebe-se em meio à lista de correspondentes da revista que

"das 44 personalidades arroladas apenas três eram brasileiras (visconde do Bom Retiro, Thomas Coelho de Almeida, D. S. Ferreira Penna); dentre os demais nomes, constam figuras de destaque Paul Broca, Charles Darwin, Quatrefages ou L. R. Turlaine -, que 
parecem representar a adesão da publicação do $\mathrm{MN}$ ao movimento científico internacional" (SCHWARCZ, 1993: 72).

Dois outros pontos chamam ainda a atenção no Museu Nacional: o primeiro deles diz respeito às posturas adotadas neste museu e em seu periódico, os Archivos do Museu Nacional, com relação à prioridade com que foram tratados os pesquisadores nacionais, vindo desta forma a esboçar uma característica diferenciada em meio aos outros museus brasileiros do período; além disto, e abstendo-se o fato de que a maioria dos trabalhos do Museu Nacional sucederam-se sob uma ótica física e biológica, enxergamos na figura de Ladislau Netto um grande incentivador da arqueologia no Brasil, sendo o responsável pelo envio de missões a diferentes partes do país para coletar objetos em vias de serem destruídos antropicamente, ou para procederem a escavações. Ambos os tipos de iniciativas deram a Ladislau Netto um acúmulo de conhecimentos suficiente para poder escrever o livro 'Investigações sobre a Archeologia Brasileira' (1885), "um trabalho monumental sobre a arqueologia das regiões mais diversas do território nacional" (PROUS, 1992: 9).

Organizador da "Exposição Antropológica Brasileira", em 1882, Ladislau Netto é considerado na literatura arqueológica nacional como tendo sido um dos principais incentivadores, senão o 'pai', da arqueologia no país. Contudo, o estudo de Margareth Lopes nos anos 1990, citada por BRUNO: 1995, dá conta de que durante a gestão deste cientista o Museu Nacional possuía uma de suas quatro seções científicas dedicada a "Numismática, e Artes Liberais, Arqueologia e Usos das Nações Modernas" e que nesta seção sobressaiam-se os estudos relativos à Numismática e Antigüidade Clássica. Esta situação só reforça a idéia de que a inserção de elementos arqueológicos correspondia à ordem e significados internacionais, ficando os bens arqueológicos nacionais vinculados a ima ordem natural.

No mais, é interessante notar que apesar de existirem outros museus etnográficos no Brasil somente o Museu Nacional manteve-se pesquisando na área de arqueologia ao longo do período que transcorre entre as duas guerras mundiais e, com efeito, até 1950 além das informações deste museu pouco foi acrescentado 
ao que já se conhecia antes de 1914, em termos de arqueologia brasileira. Contudo isso não significa dizer que a situação de ostracismos das fontes arqueológicas nesta instituição tenha sido alterada.

\section{$\underline{\text { O Museu Paraense Emílio Goeldi }}$}

Desde há muito a região amazônica atraiu os olhares de brasileiros e, essencialmente, de estrangeiros. Assim, várias foram as missões que um pouco antes do século XIX e ao longo deste embrenharam-se na vegetação amazônica, embora buscassem nesta o exótico e não o científico.

Este panorama mudou quando um grupo de intelectuais locais juntou-se ao secretário da província do Pará, Domingos Soares Ferreira Penna, com o intuito de formar uma instituição de pesquisa científica em meio à floresta amazônica, o ano era 1866 e assim surgia a Sociedade Philomática (de amigos do conhecimento) do Pará. Deste núcleo partiram as idéias para a criação do Museu Paraense, o qual foi inicialmente instalado em um espaço vinculado à biblioteca pública de Belém em 1867, tendo sido inaugurado em 1871 - o início do Museu Goeldi coincide com a ascensão da Borracha como ciclo econômico, isto não só para a região, mas para o país (BITTENCOURT, 2006).

O museu paraense durante muito tempo ficou sob a batuta de Ferreira Penna, um naturalista autoditadata autor de várias descobertas relacionadas às culturas arqueológicas da região Norte, em meio as quais se destacam: sítios da cultura Maracá (depois Mazagão), no Amapá, o estudo de inscrições rupestres e sambaquis fluviais na área do rio Xingu e os tesos do Pacoval, em Marajó, "dos quais foi o primeiro a tomar conhecimento, tendo publicado numerosas notícias sobre a arqueologia amazônica" (SOUZA, 1991: 63).

Este museu foi erguido para aglutinar uma intelectualidade já existente e, também, para contribuir na formação de novos intelectuais pautados nos ensinamentos veiculados no museu de Belém, motivo pelo qual ele cumpriria a função de Academia de Ciências em uma região desprovida de universidades e instituições científicas. 
Contudo, o museu paraense viveu situações bastante atribuladas em seus primeiros anos e passou à órbita do governo da província ainda no início da década de 1870, quando, talvez até de forma pior do que antes, passou a padecer com a falta de recursos advindos de um império brasileiro em decadência, vindo inclusive, a ser fechado pelos deputados da Assembléia Legislativa em 1888.

Mas, influenciado pela ascensão do 'ciclo da borracha' na região Norte o Museu Paraense ressurgiu e em 1894 passou a ser administrado pelo suíço Emílio Goeldi $^{11}$. Responsável por uma reorganização do Museu Paraense, em meio a qual antropologia, arqueologia e etnologia ganharam uma mesma seção, Goeldi buscou tornar o museu "uma reprodução fiel das instituições congêneres européias" (SCHWARCZ, 1993: 85).

Ao longo da administração de Emílio Goeldi o museu foi freqüentado por vários pesquisadores estrangeiros, dentre os quais figura o etnólogo Curt Nimuendaju - responsável pela formação de uma das mais representativas coleções arqueológicas brasileiras. Outro projeto de Goeldi para o Museu Paraense foi a criação de dois periódicos: o 'Boletim do Museu Paraense de História Natural e Etnografia' e a 'Memória do Museu Paraense'. Contudo, e apesar do

"número inicial do boletim do museu destacar questões como a origem do homem americano ou se referir à região amazônica como palco ideal para o estudo do homem primitivo, fica clara a orientação do museu (...) como continuação do trabalho dos naturalistas estrangeiros" (BARRETO, 2000: 39).

A crise da borracha em 1910 fez com que as atividades científicas do MPEG fossem interrompidas, provocando o esfacelamento da equipe montada por Goeldi. Durante pouco mais de duas décadas o museu se manteve devido ao atrativo gerado por seu parque zoobotânico e de suas coleções, principalmente, as

\footnotetext{
${ }^{11}$ O suíço Emílio Augusto Goeldi veio para o Brasil no início dos anos 1880 para ser pesquisador do Museu Nacional, de onde saiu com o advento da República devido ao problema político que representava sua simpatia por D. Pedro II. De 1894 a 1907 esteve na direção do, à época, Museu Paraense de História Natural e Etnográfica. Afastou-se em 1907, tendo deixado um museu que é referência em pesquisa científica e, também, tendo contribuído, por meio de seus estudos, para que o Amapá fosse reconhecido como parte integrante do território brasileiro. Por este motivo, aliás, é que foi homenageado com a mudança no nome da instituição para Museu Paraense Emílio Goeldi MPEG (BITTENCOURT, 2006).
} 
etnográficas e as de arqueologia. Após o início do primeiro governo Vargas (1930 1937) é que voltam a ocorrer investimento no museu paraense. Este período iniciado na década de 1930 marca também uma espécie de mudança de paradigma no MPEG. Sob a administração do advogado Carlos Estevão de Oliveira (1931 - 1946), - MPEG passa de museu de história natural à instituição de pesquisas aplicadas. Isto significa dizer que a pesquisa passa a atuar legando dados que possibilitam a extensão do conhecimento e, também, sua adoção para fins comerciais, como forma de viabilizar recursos que permitem a manutenção da pesquisa básica. Somente desta maneira é que se tornou possível, por exemplo, o incremento das atividades de campo, que resultaram em um considerável aumento nas coleções do MPEG.

"O período que se seguiu à morte de Oliveira, apesar de marcado por dificuldades, apontou alguns caminhos que se revelaram promissores, como a instituição das pesquisas arqueológicas conduzidas por Bety Meggers e Clifford Evans, cientistas do Smithsonian Institution, nos Estados Unidos - o que marcou, graças aos novos métodos, o início da moderna arqueologia brasileira" (BITTENCOURT, 2006: 159).

\section{$\underline{\text { O Museu Paulista }}$}

Resultado de um projeto antigo que tomou fôlego a partir do "enriquecimento econômico da região, um museu em São Paulo parecia constituir um suporte para outras significações, representando a ascensão de uma nova província no cenário nacional" (SCHWARCZ, 1993: 79).

Com os materiais egressos de diversos museus particulares e, principalmente, do Museu Sertório, museu pertencente ao Cel. Joaquim Sertório que era aberto à visitação pública desde 1883 - entre os quais constavam espécimes de História Natural, jornais, objetos indígenas e peças de mobiliário -, e, também, com "algumas peças preciosas e únicas do patrimônio arqueológico e histórico nacional, adquiridas pelo estado de São Paulo em 1890" (BREFE, 2005: 21), o Museu Paulista foi inaugurado em setembro de 1895 sob a direção do zoólogo Herman Von Ihering. 
Este recém-inaugurado museu possuía um projeto profissional simulado ao dos grandes centros europeus e, segundo seu diretor, igualado no Brasil somente pelo Museu Paraense. A partir de postulados das ciências biológicas, fundamentados em teorias evolutivas e classificatórias, o Museu Paulista lançou o primeiro número de seu periódico também em 1895, sob o nome de Revista do Museu Paulista.

Desde o primeiro número desta revista dava-se a largada em uma forte adversidade entre o Museu Nacional, representativo de uma monarquia envelhecida, e o Museu Paulista, republicano e progressista. Esta adversidade pode ser atribuída, enfaticamente, ao diretor do museu, Herman lhering, do qual cabe ainda explicitar que teve uma produção onde

\begin{abstract}
"seu tratamento das coleções arqueológicas talvez seja o mais representativo da forte herança do naturalismo alemão ainda hoje presente na arqueologia brasileira. O taxonomismo cultural, esvaziado de dimensões humanas e sociais, marcou de forma decisiva uma incipiente ciência do homem, na qual, no dizer de Ihering, 'estudar a flora e a fauna era também estudar o homem primitivo'” (BARRETO, 2000: 38).
\end{abstract}

A institucionalização da pesquisa arqueológica no Museu Paulista, assim como nos outros museus aqui esboçados, demonstra um processo marginal em relação ao nacionalismo premente a nova República. Este processo particularizou a arqueologia e a oficializou em meio às Ciências Naturais, retirando-a de uma ligação com os elementos históricos e sociais do século XIX e tornou-a, também, um campo fértil para a presença estrangeira. No Museu Paulista, assim como nos outros museus, os vestígios pré-coloniais sempre estiveram na gênese das coleções organizadas, contudo sempre foram colocados à margem do processo de musealização.

A presença de três museus etnográficos em solo brasileiro ao menos em teoria tenta prenunciar uma unidade de métodos que não foi vista.

"Apesar das similaridades, entre essas três instituições estruturadoras das idéias e imagens que se têm até hoje, neste país, sobre museus científicos - muitas diferenças marcaram suas 
distintas atuações. O Museu Nacional contou com grande apoio do Império, inclusive recebendo doações de coleções estrangeiras. $\mathrm{O}$ Museu Paraense Emílio Goeldi dedicou-se à uma abordagem regional, atuando como uma porta para a compreensão da região amazônica. O Museu Paulista reuniu coleções ecléticas com o objetivo de agradar as exigências da elite local" (BRUNO, 1999a: 82).

Apesar disto, não se pode esquecer o papel destes museus, pois, sem 0 intento de se chegar ao homem por meio da fauna e flora, classificando-a, hierarquizando-a e expondo seus atributos nos museus, jamais se teria aberto espaço para pesquisas científicas em solo brasileiro. Isto se deve inclusive à presença dos pesquisadores estrangeiros que vieram para essas instituições. Se o trabalho destes cientistas resultou na expropriação de bens e espécimes brasileiros, levados para museus fora do país, deve ser considerado também que "a presença desses pesquisadores acabou incentivando novas gerações de estudiosos brasileiros" (BRUNO, 1995: 103).

A herança destes museus possui vinculação com um tipo bem específico de classificação, onde o evolucionismo social era alcançado por meio de analogias biológicas de forma que os grupos sociais eram substituídos por organismos vivos. O foco direcionava-se para uma seriação da vida humana, valendo buscar as raízes mais 'atrasadas' da humanidade. "No caso brasileiro, no entanto, a noção de evolução social se viu diretamente associada ao problema da raça e de suas possíveis implicações" (SCHWARCZ, 1993: 92).

Neste momento os museus tornam-se o reflexo, talvez indireto, de discussões sócio-políticas e atuaram na vanguarda de idéias relacionadas ao atraso proporcionado pela miscigenação. Não bastasse isto, tentam das mais variadas formas estudar e apontar na direção de um processo de branqueamento da população que aumentaria a cada ano.

O século $X X$ surgiu para os museus etnográficos brasileiros como 0 prenúncio de que mudanças eram necessárias para se manter de pé. Não bastassem crises econômicas, ocorreu a transferência dos projetos enciclopédicos para as universidades e a entrada em campo de teorias que demonstravam o fato de não ser mais viável explicar o homem a partir de vegetais e animais, a partir daquele 
instante percebia-se que "polvo é polvo. Molusco é mesmo molusco" (SCHWARCZ, 1993: 97).

Contudo, isto não se refletiu numa maior aproximação, ou valoração, de certos elementos que compõem o patrimônio brasileiro, tanto que se tornou comum aos brasileiros não se relacionar com os bens arqueológicos como parte de suas memórias, o que é causa, ou efeito, do fato de que "a produção em arqueologia tem ficado, em geral, circunscrita à divulgação e conhecimento entre pares" (BRUNO, 2005: 237).

Isto pode ser apontado também a partir do deslocamento do eixo das pesquisas para as universidades, algo que sem dúvida forma mais uma camada na estratigrafia do abandono, dado que

\footnotetext{
"a partir desse momento, diversas universidades abrigaram ou criaram instituições arqueológicas. (...) O envolvimento com a universidade (ou pelo mundo universitário, revelou-se como mais um elemento que afastou os museus de Arqueologia para um espaço coadjuvante" (BRUNO, 1995: 122).
}

Nas duas últimas décadas do século XX, o fenômeno de ligação da pesquisa às universidades, absorveu duas destas instituições o Museu Paulista e o Museu Nacional, que hoje integram respectivamente as estruturas acadêmicas da USP (Universidade de São Paulo) e da UFRJ (Universidade Federal do Rio de Janeiro), a única exceção foi o Museu Paraense Emílio Goeldi, órgão ligado diretamente ao governo federal por meio do Ministério da Ciência e Tecnologia.

O Museu Nacional mantém ainda traços de seu antigo projeto enciclopédico. $\mathrm{O}$ acervo arqueológico deste museu é composto por materiais da Antiguidade Clássica (Grécia e Roma), do Egito Antigo, de povos Pré-Colombianos e da Arqueologia Brasileira. A disposição expográfica dos elementos culturais relativos ao passado pré-colonial brasileiro é feita de uma maneira a abarcar os elementos da cultura material pré-histórica, feitos em pedra e osso, a formação de sítios do tipo sambaqui e a diversidade cultural de povos como os Tupi-guarani e os Marajoara. Na última década, o museu deu início a um amplo projeto de restauração 
e reforma de suas instalações e, da mesma forma, de revisão e reorganização curatorial de suas coleções.

O Museu Paulista teve seu acervo decomposto nas últimas décadas do século $X X$, dando origem a outras instituições como o Museu de Zoologia e o atual Museu de Arqueologia e Etnologia, este último contou também com coleções advindas do Instituto de Pré-História, do antigo Museu de Arqueologia e Etnologia e do Departamento de Antropologia da Faculdade de Filosofia, Letras e Ciências Humanas. A partir desse processo de fusão de acervos e profissionais, ocorrido em 1989, o Museu Paulista que no final dos anos 1960 iniciou as atividades relativas ao Projeto Paranapanema ${ }^{12}$, se tornou um museu apenas de caráter histórico.

O Museu Paraense Emílio Goeldi manteve seu projeto regional e hoje, enquanto instituição de pesquisa, se mantém sempre atuante no que diz respeito a buscar estratégias de desenvolvimento para a região Norte do Brasil. Nos anos noventa foi estabelecida uma área de Museologia, hoje sob o âmbito da Coordenação de Comunicação e Extensão e que encaminha projetos relativos à educação e a museografia. Como forma de atender à demanda desenvolvimentista da região, a área de arqueologia deste museu se dedica na atualidade com uma maior freqüência aos projetos de prospecção e salvamento arqueológico em regiões impactadas pela exploração econômica.

Estas instituições criadas no século XIX adentraram ao século XX e hoje manifestam a peculiaridade de serem contemporâneas das instituições abordadas nesta dissertação, principalmente no que tange a algumas posturas relativas à Musealização da Arqueologia.

O dilema de explicar o resultado de pesquisas arqueológicas ao público em geral (leigo), é uma preocupação que integra debates recentes na arqueologia. Neste sentido, a arqueologia cruza a fronteira com a museologia, para, em uma via de mão dupla, receber e legar informações com o objetivo de incentivar "a devolução à sociedade do conhecimento produzido e da herança constituída a partir do

\footnotetext{
12 Programa de pesquisas arqueológicas iniciado em 1968 com a escavação, conduzida pela arqueóloga Luciana Pallestrini, do Sítio Fonseca no município de Itapeva/SP e que chegou aos anos noventa com equipes cobrindo e atuando ao longo das três bacias (superior, média e inferior) do Paranapanema, sendo que apoiadas procedimentos e nomenclatura comuns e, também, sustentados por um plano cartográfico bastante sofisticado (BRUNO, 1995).
} 
trabalho arqueológico" (CÂNDIDO, 2004: 12). Dessa maneira, podemos dizer que na contemporaneidade tanto a museologia quanto a arqueologia têm percebido que 0 patrimônio só passa a ser uma herança quando as pessoas passam a apropriá-lo na sua realidade cotidiana, dessa apropriação e da consciência acerca desta herança é que resulta em última instância a preservação do patrimônio.

A relação entre a arqueologia e a museologia está para além do aspecto comunicacional que pode emanar desta última, ambas se definem a partir de sua ligação com a cultura material. "A museologia é a ciência do Museu e das suas relações com a sociedade; é, também, a ciência que estuda a relação entre o Homem e o Objeto, ou o Artefato, tendo o Museu como cenário desse relacionamento" (RÚSSIO, 1979). Já

\begin{abstract}
"Pearce (1990:31) afirma que a Arqueologia é, acima de tudo, uma disciplina ligada à compreensão da cultura material em amplo sentido - não necessariamente ligada ao produto das escavações -, e que muito disto está preservado nas coleções dos museus. Da mesma forma, Francisco Alves, então diretor do Museu de Arqueologia e Etnologia de Portugal declarou que a reorganização das reservas que originou a exposição 'Das Origens à Época Romana' (1989 1994) tinha sido, até aquele momento, 'a maior escavação arqueológica portuguesa' (Alves, apud Raposo e Silva, 1996: 165)" (CÂNDIDO, 2004: 15).
\end{abstract}

Entender a arqueologia enquanto ciência que estuda a cultura material implica, entre outros aspectos, percebê-la em uma interface, às vezes constante, com outras ciências que, embora sobre outros aspectos, também dão conta da materialidade que circunda o homem. Assim, por exemplo, temos a antropologia, a zoologia, a etnologia e, a museologia. Um exemplo desta interface é pois o fato de que de certa forma várias pesquisas arqueológicas ou possuem origem em um museu ou nele 'terminam', sem querer dizer com isto que o trabalho do arqueólogo possui um fim 'na porta do museu', isto porque

"a problematização das hipóteses arqueológicas procura, sobretudo, elucidar os processos de continuidades e mudanças dos diferentes grupos humanos. Por um lado essa busca orienta-se para a compreensão das possibilidades de 
dispersão dos vestígios materiais (evidências culturais) em um território e, a partir de diferentes metodologias, esses vestígios acabam sendo retirados de seu local de origem e reunidos em uma instituição. Por outro lado, muitos destes estudos partem de objetos já reunidos em instituições, com o objetivo de entender o perfil das sociedades que os produziram" (BRUNO, 1995: 141).

A sociedade costuma valorizar o patrimônio arqueológico apenas como curiosidade, abstraindo deste a possibilidade que oferece de, uma vez estudado, servir para identificar e compreender as continuidades e mudanças dos processos culturais das sociedades nativas, nas suas mais diferentes características (BRUNO, 1999a). Por outro lado, o museu (apesar de também ser um espaço de "curiosidades") pode ser visto como detentor de objetos do passado, feitos no passado e que, por estarem em um museu, adquirem de certa forma a capacidade de mediadores do passado junto à contemporaneidade.

"Cabe salientar que a Museologia oferece à Arqueologia uma oportunidade especial de aproximação sistemática com a sociedade presente, uma vez que vincula suas principais preocupações em dois níveis, a saber:

$\left.1^{\circ}\right)$ identificar e analisar o comportamento individual e/ou coletivo do homem frente ao seu patrimônio.

$\left.2^{\circ}\right)$ desenvolver processos técnicos e científicos para que, a partir dessa relação, o patrimônio seja transformado em herança $e$ contribua para a construção das identidades.

Os vestígios das sociedades que correspondem ao interesse de estudo da Arqueologia, são, também, elementos da herança patrimonial, tratados e comunicados pela Museologia" (BRUNO, 1995: 141 - 142).

Assim sendo e, não obstante suas variáveis, a construção de significados e relações com o patrimônio (o passado), é algo comum tanto à arqueologia quanto à museologia. Contudo, ressalta-se o fato de que, uma vez os objetos estando em um museu, eles adquirem novas significações, seja por meio de um discurso construído, ou através das características que envolvem o gerenciamento destes. É neste sentido, inclusive, que se observa 
"uma estratigrafia do abandono que isolou as fontes arqueológicas e as circunscreveu ao terreno das memórias exiladas. No âmbito das instituições que preservam acervos, as coleções arqueológicas têm pouca articulação com outros conjuntos patrimoniais" (BRUNO, 2005: $237-238)$.

Conjuntos patrimoniais seriam, pois, os bens tidos como referência para determinados grupos sociais, isto porque como veremos a seguir o patrimônio é algo muitas vezes setorizado e influencia de maneira diferente a construção das identidades. Isto significa também dizer que o patrimônio possui não só conceitos diferentes, mas também graus diferentes de valoração e que estes graus podem ser trabalhados a partir das referências sócio-históricas que se tem, ou que se buscam, em determinadas conjunturas.

\section{Sobre patrimônio(s).}

Patrimônio é um termo muito presente na atualidade "património, esta obsessão dos nossos tempos - ou patrimónios, seria melhor começar a conjugá-los no plural - só ganha destaque quando a sociedade começa a ter meios para radicalmente varrer do território tudo quanto o caracterizava secularmente" (JORGE, 2000: 19). Contudo, a idéia de patrimônio parece manter seu significado primeiro, algo que se refere às gerações passadas, ou, num uso latino do termo, 'patrimonium' como algo que podia ser legado a outrem e que por isso figura como uma herança.

Ao termo patrimônio acrescenta-se na maioria dos casos o termo histórico e, também, não raras vezes, este unitermo toma corpo com a adição da idéia de artístico. Isto na prática cria um outro unitermo, patrimônio histórico e artístico, desta forma assegurasse de uma maneira mais clara que o sentido da noção de patrimônio está carregado de um significado, que se tornou mais nítido nos últimos anos, o significado cultural.

"A noção de patrimônio como a conhecemos hoje nem sempre foi assim, sua função foi sendo modificada ao longo dos séculos, incorporando novos valores e perdendo antigos referenciais. 
Apresentando-se como objeto de preocupação já durante a segunda metade do século XIX, a noção de patrimônio consolida-se mesmo com os processos de formação dos Estados Nacionais, onde serve como justificativa ideológica para a construção de uma identidade" (COSTA, 2004: 335).

Ao historicizar-se a idéia de patrimônio percebe-se que desde a origem latina do termo ('Patrimonium', tudo que pertencia ao 'pater' ou 'pater famílias'), até a elaboração do conceito de patrimônio com o advento dos estados nacionais, passase por uma série de percepções que sintetizadas apontam para um significado de patrimônio como algo que no início era relacionado basicamente a um grupo específico, aqueles cujos membros tinham posses passíveis de herança, por exemplo, a aristocracia. A este significado, a partir do final da Idade Antiga e ao longo de todo o período Medieval, foi acrescido um significado também religioso. Este último, já durante o Renascimento, foi combatido em favor de um (re)descobrimento da Antigüidade Clássica:

"Os humanistas começaram a se preocupar com a catalogação e coleta de tudo que viesse dos antigos: moedas, inscrições em pedra, vasos de cerâmica, estatuária em mármore e metal. Vestígios de edifícios também eram medidos, desenhados e estudados com grande dedicação" (FUNARI \& PELEGRINI, 2006: 12 - 13).

A formação dos estados nacionais muda a concepção acerca do patrimônio de algo que era particular, que pertencia a determinado grupo ou determinada pessoa, para um coisa pública que dá significado a uma nação. Saiu-se de um âmbito privado para a intencional difusão do patrimônio como algo relacionado às origens dos povos, o elemento norteador e a justificativa para os espaços territoriais e os idiomas (a adoção de uma única língua para uma nação). Neste sentido, observamos uma forte relação entre a noção de patrimônio e às identidades, donde, diz-se que "património sempre teve a ver com identidade, com valores não materiais, simbólicos, e com a memória dos indivíduos e dos grupos" (JORGE, 2000: 20).

O patrimônio nacional concebido a partir desta perspectiva vive seu ápice no período de 1914 - 1945, entrecortado por duas grandes guerras e onde o 
patrimônio em alguns casos foi, inclusive, justificativa para a expansão territorial da Alemanha nazista. Após este período, o nacionalismo perde espaço e da mesma forma a noção de patrimônio então vivenciada é acrescida já na década de 1970 de novos valores. Este momento coincide inclusive com a insurgência de alguns movimentos que passam a reivindicar a valorização de seus testemunhos, como no caso, por exemplo, de organizações quilombolas. Deste momento em diante a noção comum de patrimônio passa a ser transversal e abarca não só o excepcional, mas também o aparentemente comum e o que possui representatividade para os Homens, como por exemplo, uma paisagem ou uma música. A idéia de herança, esta posta como algo que possui representatividade e nem sempre o que é dotado de representatividade é algo fisicamente construído, o patrimônio passa a ser também imaterial, mas, antes de tudo, passa a ser cultural e digno de preservação.

Políticas de preservação ao patrimônio cultural na América Latina são recentes, basicamente, passaram a ocorrer depois que a UNESCO reconheceu bens culturais latino-americanos como patrimônio da humanidade e durante bastante tempo estiveram mais restritas ao âmbito da administração pública. Um exemplo disto é o fato de que, exceção feita aos esforços de Paulo Duarte nas décadas de 1940 - 1960, "as políticas de preservação ao patrimônio arqueológico no Brasil basicamente estiveram restritas as ações governamentais" (CALI, 2005: 8). Isto, entre outros aspectos, evidencia, inclusive, uma maior inclinação da comunidade científica à pesquisa e não à preservação.

O caminho da preservação tem sido algo buscado veementemente a partir da segunda metade do século XX. Exemplos deste novo momento são a Carta de Veneza, 1964, e a Declaração de Amsterdã, 1975. Estes documentos refletem o intuito básico de recomendar a preservação de obras com significado cultural e conjuntos patrimoniais, como, por exemplo, um bairro de interesse histórico e cultural. São mecanismos que visam ainda, ou pressupõem, um maior envolvimento da população nos processos de preservação e evidenciam, de certa forma, prolegômenos de uma relação de interesse identitário mesmo (ou principalmente) que de uma forma mais local. Não obstante isto, a Declaração de Amsterdã, por exemplo, atribuiu ao poder público municipal uma maior responsabilidade sob a 
preservação patrimonial. Talvez por isso, é que "a partir de fins dos anos 1970 e início da década de 1980, foi o momento dos municípios se preocuparem em assumir suas atribuições constitucionais para a defesa do patrimônio cultural" (CALI, 2005: 10).

O disposto nestas cartas foi cumprido de forma diferente nos mais variados países. No caso da América Latina, por exemplo, se observa que a diversidade cultural, as longas extensões territoriais e também as características sócio-históricas da região ampliaram os desafios relativos ao cumprimento destas disposições legais e geraram algumas dificuldades que não foram superadas, principalmente no que diz respeito à preservação patrimonial por parte dos municípios. Especificamente no caso brasileiro, podemos ainda dizer que as políticas públicas direcionadas ao patrimônio cultural têm oscilado entre a transparência e a inexistência, ou não aplicação, além do fato de que a maior parte destas se insere na esfera federal.

Como é o caso da primeira lei relacionada ao patrimônio arqueológico brasileiro, a 3.924 de 1961. Contudo, mesmo depois desta lei e das portarias do Instituto do Patrimônio Histórico, Artístico e Nacional - IPHAN / Ministério da Cultura, publicadas nos anos 1990 e início dos anos 2000 observamos que "a normatização da legislação patrimonial (arqueológica) ainda não se preocupou com a extroversão museológica” (BRUNO, 1995: 134).

Nos anos 1980 com a promulgação da Constituição Federal de 1988, observamos que os anseios acerca de uma noção mais ampla de patrimônio foram, embora parcialmente, atendidos. Porém, isto nos faz também perceber que a ampliação da noção de patrimônio histórico e artístico para patrimônio cultural, ocorrida no final dos anos 1980, não foi acompanhada de mediadas que facultassem o envolvimento dos grupos sociais com os bens que os circundam.

Não obstante isto, se observa também que o patrimônio passou então a ser visto como uma construção sócio-histórica, assim como os atos em sua defesa. Isso permitiu entender como patrimônio algo além dos bens antes relegados ao esquecimento, por exemplo, estações de trem e os saberes e fazeres. "Dessa forma, patrimônio cultural, no qual a arqueologia é uma das ciências que lhe dão um 
'corpus', é compreendido como um legado, de diferentes formas de registro, das múltiplas memórias sociais" (CALI, 2005: 19).

Assim sendo, temos o patrimônio cultural como algo que está relacionado aos processos históricos e sociais de um povo, ou de uma nação. A partir das palavras de Hugues de Varine-Bohan, observa-se que este patrimônio pode ser dividido em três categorias: 1) os elementos de origem natural (clima, ambiente, geologia, etc.); 2) os da ordem dos saberes e fazeres, algo que não é tangível e que optou-se por chamar de patrimônio imaterial; e, a categoria de maior densidade e mais explorada, os bens culturais materiais, ou os objetos, os artefatos e as construções (VARINE-BOHAN Apud LEMOS, 2004).

Neste sentido, entende-se, entre outros aspectos, que artefatos e construções, saberes e fazeres e o ambiente se interconectam, de modo que podemos pensar em relações homem - artefato, natureza - homem, e assim sucessivamente. Isto, em outras palavras, nos remete a entender patrimônio como, "o conjunto dos bens, fruto das relações entre os homens e os recursos naturais; entre os homens em sociedade; e as interpretações que são elaboradas a partir destas relações" (BRUNO, 1999b: 333), conforme já foi apresentado na Introdução deste trabalho. Enxergamos neste conceito que o patrimônio (cultural) é composto por vários bens (culturais) e estes são entendidos como

"toda produção humana, de ordem emocional, intelectual e material, independente de sua origem, época ou aspecto formal, bem como a natureza, que propiciem o conhecimento e a consciência do homem sobre si mesmo e sobre o mundo que o rodeia" (GODOY Apud ORIÁ, 2002: 132).

Podemos então, a título de exemplo, elaborar o seguinte esquema:

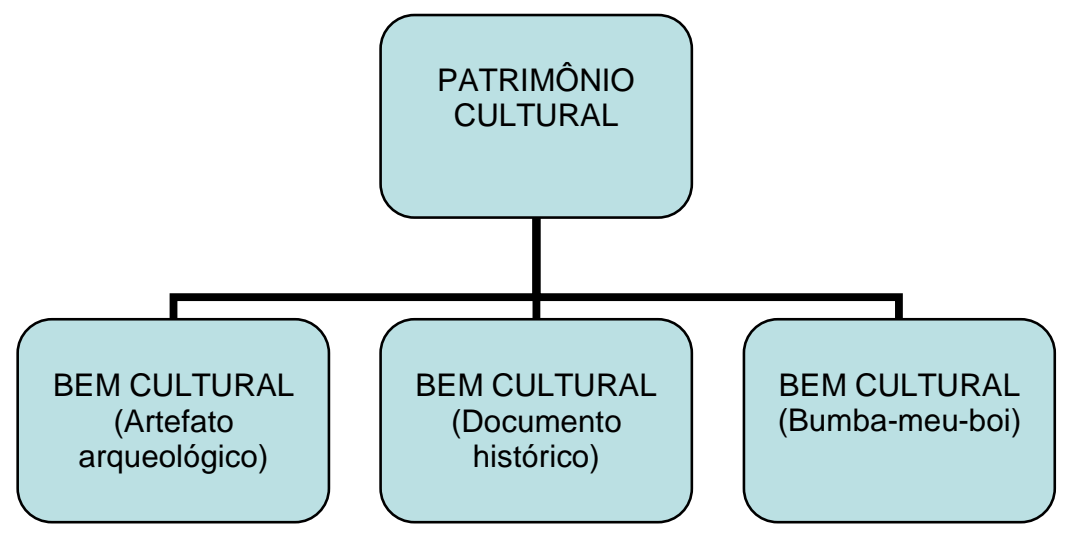


Esta configuração pode ser também observada, inclusive, na dificuldade que se tem de obter uma visão global do que é patrimônio, donde, por exemplo, apesar de serem 'homens das letras' "os historiadores, os arqueólogos, os antropólogos, os músicos, os intelectuais variados, sempre procuram preservar, de um jeito ou de outro, bens culturais ligados ao seu campo de atuação" (LEMOS, 2004: 31).

Em outras palavras, podemos dizer que existe uma ambigüidade, ou variação, no sentido (significado) e na escolha do que seja patrimônio, ou, por exemplo, patrimônio arqueológico. Tal ocorrência, no caso mais amplo, dá-se, entre outros aspectos, pela dificuldade em se amealhar o que seria 'nosso' patrimônio e o que seria 'meu' patrimônio, isto porque nem tudo que é evidenciado como patrimônio para um indivíduo o será para um grupo, ou até mesmo para uma outra pessoa. É também possível enxergar tal dificuldade à luz de dois fatores: a) a percepção de que a idéia de patrimônio é algo ligado aos valores sociais de uma época, e neste caso é inevitável uma mudança em seu significado, dado que os valores sociais mudam ao longo do tempo; b) devido ao fato de que as discussões teóricas travadas no âmbito de uma ou mais ciências podem resultar na elaboração de um outro conceito.

Destes dois fatores, enxergamos no fator 'a' uma proximidade maior com nosso trabalho. Isto porque o patrimônio arqueológico é no mais das vezes e, principalmente, no caso brasileiro um patrimônio que se vê desprovido de monumentalidade e que em alguns casos pode ser associado ao elemento indígena. É possível que justamente essa aproximação com o elemento indígena dificulte o reconhecimento dos bens arqueológicos como parte integrante do nosso patrimônio.

Este mesmo patrimônio pode ser genericamente dividido, de uma forma mais ampla do que a de Varine-Bohan, em dois segmentos, um de ordem material e outro imaterial - na atualidade, compelindo-se, inclusive um ordenamento jurídico especifico para cada um destes. Nesta dissertação nos importa de modo mais estrito, os acervos ligados à arqueologia e que estão em museus. Para nós estas coleções representam a cultura material de sociedades ou grupos humanos 
pretéritos, materiais arqueológicos, ou bens do nosso patrimônio arqueológico ${ }^{13}$, entendendo aqui que "arqueológico não é apenas o que está soterrado ou submerso, ou o que desponta ou emerge como ruína. Não é apenas o que escavamos e trazemos à luz" (JORGE, 2000:130).

Por outro lado, tornou-se também relevante conhecer o que foi produzido ou a imagem que foi produzida a partir desse patrimônio, ressaltando-se a capacidade que estes acervos possuem de comunicar informação e também, como estas informações foram ou não trabalhadas para a construção das identidades nos lugares onde essas instituições se fazem presentes.

\section{Identidades e museus no Nordeste do Brasil.}

A construção de qualquer identidade perpassa, obrigatoriamente, pela consecução de uma memória individual e coletiva. Não obstante isto, se sabe ainda que esta mesma memória é geralmente adquirida por meio de um discurso ideologizante. Contudo, há que se reconhecer o papel essencial que os objetos possuem nesta memória, justamente, por endossarem a conformação desta última e atuarem como sustentáculo de interpretações legitimadoras, presentes em discursos históricos.

Assim, através dos objetos, muito do que existiu em épocas pretéritas pode ser recuperado e também preservado, desde que seja feito à luz do que se faz mister no tempo presente. Dessa forma, fica patente que os objetos não representam o passado em todos os seus ditames diários, o passado exatamente como ele existiu é uma utopia que da mesma forma não será encontrada circunscrita a uma interpretação histórica, nem tampouco, num resgate 'memorialístico', pois, a "memória, portanto, enquanto ato de lembrar e esquecer o passado, é o ato de construir certas imagens, as quais, à medida que se formam, se distanciam do

\footnotetext{
${ }^{13}$ Nosso conceito é, portanto, diferente do que está presente em textos como, pó exemplo, o da "Carta de Goiânia" - elaborada durante a III Reunião Científica da Sociedade de Arqueologia Brasileira, Goiânia/GO, em 1985 -, em cujo texto figura uma definição do que seriam Bens Culturais Arqueológicos: "Os arqueólogos reconhecem como tais bens abrigos e cavernas ocupados pelo homem pré-histórico, inscrições rupestres, esculturas e pinturas, acampamentos e aldeias, restos de edificações históricas e quaisquer elementos incluídos nesses contextos, bem como os vestígios arqueológicos encontrados e colecionados por amadores"
} 
passado para se tornarem novas realidades capazes de interferir diretamente no mundo que as criou" (SANTOS, 1992: 219).

Dentro deste contexto, as próprias propostas e práticas museológicas têm buscado direcionar-se para novas linhas de atuação na medida em que tornam a memória e os objetos algo díspar em seus aspectos estritos. Desta forma, é atribuído sentido a estes objetos de acordo com uma nova história tematizante que os museus, com uma interpretação a qual lhes é cara, buscam acompanhar através de uma subordinação dos objetos aos temas. Daí porque

"os objetos não são expostos segundo uma ordem cronológica, nem apresentam uma identidade temporal entre eles dentro das vitrinas, mas estão inseridos numa configuração que claramente organizam os temas segundo uma perspectiva evolutiva que tem o tempo linear como pressuposto. Quem tem, portanto, a prioridade e cumpre uma linearidade temporal aqui são os temas e não os objetos, que aparecem apenas como ilustrações daqueles" (SANTOS, 1992: 224).

Deste modo surgiu uma nova forma de relacionar a memória e os objetos, buscou-se, ou busca-se, tornar-se alheio à tradição e optar por uma nova interpretação do passado em que não estivesse presente a utopia e o autoritarismo, já tradicionais em museus de outras épocas. Mesmo assim, parece que, às vezes, o passado re-criado em museus contemporâneos não faculta a reflexão e se esquece de que a memória institucionalizada relega ao esquecimento aquilo que, sob sua perspectiva organizacional, parece desnecessário e inoportuno. "Com isso os museus, enquanto suporte da memória institucionalizada, perdem gradativamente sua função na sociedade contemporânea" (SANTOS, 1992: 234).

No que concerne ainda à formação da identidade, percebe-se certo paralelismo entre os períodos históricos e as concepções identitárias corroboradas por estes, logo, notamos a mesma tendência nos museus ou em seus 'predecessores', neste caso os Institutos Históricos e Geográficos, os quais sobressaídos em grande monta dos auspícios do período republicano, mostravamse bastante vinculados aos anseios das elites locais e principalmente na formação de identidades regionais e locais. Tanto que, ao tomarmos como exemplos os Institutos da Bahia e de Pernambuco, enxergamos notadamente os augúrios de uma 
memória ideologizante, na medida em que é portadora dos interesses das elites locais e que se faz embasada não somente pela historiografia, mas também pelos objetos.

"Desde sua fundação os IGHB e o IAGHP definiram que 0 estabelecimento das identidades baiana e pernambucana não seria garantido apenas através de uma produção historiográfica, mas de um conjunto de outros elementos que pudessem instituir a imagem visível de um passado comum. Para desempenhar esta função, os objetos materiais foram tratados como um suporte importante" (VIANA, 2002: 29 - Grifo nosso).

Parece que nesta época os objetos materiais eram estimados por um tipo de valor que os imputava "a propriedade de 'incorporar' o passado, através dos seus valores históricos e artísticos" (VIANA, 2002: 31). Em certa medida, esta mesma preocupação com os objetos de 'valor histórico' não afastará uma dúvida concernente a tal situação, pois, afinal o que possui valor histórico? Para contemplar esta dúvida é que se formou um discurso atribuindo um valor, não financeiro, para tudo que fosse pertinente à moral, ao social, ao patriótico e, é claro, ao que fosse histórico naquelas sociedades. Por conseguinte, tudo que merecesse ser guardado e preservado pelo fato de fazer parte da identidade daqueles estados. Pois,

\footnotetext{
"de fato, desde o início da formação dos dois institutos havia sido atribuído um papel fundamental aos museus para o estabelecimento das identidades baiana e pernambucana. A eles caberia garantir a produção de uma 'memória estadual', através da coleta e da conservação de objetos de valor histórico e artístico; e por outro lado, colaborar com a formação de um conhecimento positivo, através de outras coleções" (VIANA, 2002: 34).
}

Esta categoria de objetos materiais abriu espaço para que, no âmbito das relações hierárquicas e de importância dentro dos institutos históricos, uma categoria de sócios à margem da oratória e do processo de escrita da história destes lugares pudesse ganhar destaque pelas peças, ou coleções, que tornavam públicas e pertencentes à memória estadual baiana e pernambucana. Os objetos trazidos à 
tona evidenciavam dois tipos de situação: em primeiro lugar, os objetos concernentes a bravos e notórios homens que teriam figurado como paladinos de grandes acontecimentos; em segundo lugar, os objetos que são correlacionados aos grupos sociais, ou à identidade destes grupos sociais, menos favorecidos economicamente e que como tais seriam apenas co-participantes na construção das identidades locais.

Desta forma, as exposições em museus nordestinos caminharam gradativamente para uma homogeneização regionalista. Esta conformação denotava, sob alguns aspectos, uma unidade não somente geográfica, mas também temporal e cultural. A bem da verdade, até mesmo quando se buscou inovar o alvo foi justamente uma simbiose cultural obtida através de um contexto semelhante e que deveria ser ressaltado do ponto de vista da instrução pública presente, de forma não explícita, nos objetos e em seu entorno socioeconômico e geográfico. Desta forma,

"o público-alvo desse museu eram os jovens da cidade. Caberia à Instituição, através de suas coleções despertar nesse público o interesse por seu torrão natal. Deste modo, a proposta do museu se integrava à formação de um outro tipo de identidade cultural" (VIANA, 2002: 53).

A formação deste quadro de construção identitária a partir dos Institutos Históricos é de uma conformação sócio-cultural que não distingue todos os elementos participantes de uma identidade regional e que assentou as bases de projetos museológicos regionais intrinsecamente relacionados com a historiografia tradicional brasileira e suas, nem sempre diferentes, variantes locais, como no caso do Museu Histórico Lauro da Escóssia. 


\section{CAPÍTULO II}

Museu Histórico Lauro da Escóssia: estratos de uma coleção arqueológica no Oeste potiguar. 
De maneira geral podemos dizer que elementos relacionados à valorização da cultura e ciências são raros no Rio Grande do Norte, principalmente, na primeira metade do século XX. No que diz respeito à fundação de uma instituição para dar suporte a elementos de construção das identidades, o Rio Grande do Norte posiciona-se 'a posteriore' de outras unidades da federação. Contudo, apesar de sua criação tardia (março de 1902) pode ser observado no Instituto Histórico e Geográfico do Rio Grande do Norte o mesmo tradicionalismo e posturas ideológicas do Instituto Histórico e Geográfico Brasileiro, comprovando assim a idéia de "que as leituras do passado, respeitam os interesses políticos do período em que são feitas" (SCHIAVETO, 2003: 19 - Grifo da autora).

Assim sendo, não é de se admirar o fato de que a institucionalização do mais antigo museu do estado tenha surgido a partir da vontade política de um grupo de intelectuais da região Oeste do Rio Grande do Norte.

\section{Cria-se um museu, mudam-se as sedes.}

O mês de abril do ano de 1948 prenunciou à comunidade do município de Mossoró, no estado do Rio Grande do Norte, a formação de um projeto cultural que visava levar o conhecimento, em seus aspectos culturais, patrimoniais e científicos, à população dessa localidade e em um plano mais amplo para os vários municípios que compõem a região Oeste desse estado. Tal tipo de planejamento foi fruto da vontade política do então prefeito Jerônimo Dix-Sept Rosado Maia, 1948 - 1952.

Uma vez traçado o curso do projeto que pretendia o "alevantamento cultural dos mossoroenses" (O MOSSOROENSE, 1949), Dix-Sept Rosado aglutinou em seu entorno um corpo de intelectuais, alguns dos quais também políticos, da chamada capital do oeste potiguar. Esses intelectuais formavam uma espécie de comissão, responsável por levar a cabo as ações necessárias para a implementação da nova política cultural do município.

Cerraram fileira na comissão José Ferreira da Silva, Francisco Assis Silva - primeiro diretor do Museu de Mossoró, José Maria Gonçalves Guerra, Hugo Costa Cruz, Rafael Fernandes de Negreiros, João Damasceno da Silva Oliveira, José 
Romualdo de Souza, Jerônimo Vingt-Un Rosado e América Fernandes Rosado. Sobressaiu-se nesta comissão a figura de Vingt-Un Rosado, com certeza um grande incentivador da cultura não só de Mossoró, mas do Rio Grande do Norte.

As propostas da comissão desembocaram na criação de duas importantes instituições para a cidade de Mossoró: a biblioteca pública e o museu municipal, ambas criadas no mesmo período e com seus espaços físicos vinculados. Este 'centro cultural' deveria tornar-se "o meio eficiente de atender aos desejos de aprimoramento de cultura, dos que não tinham poder aquisitivo (...) e também de despertar outras tantas vocações, para as letras e para as ciências" ( $O$ MOSSOROENSE, 1949).

Nesse aspecto, podemos encontrar semelhanças com o que houve em outras regiões, como, por exemplo, no estado do Pará. Nessa região, ainda durante o Brasil Império, um grupo de intelectuais locais juntou-se ao secretário da província do Pará, Domingos Soares Ferreira Penna, com o intuito de formar uma instituição de pesquisa científica em meio à floresta amazônica, o ano era 1866 e assim surgiu a Sociedade Philomática (de amigos do conhecimento) do Pará, conforme já foi indicado no capítulo anterior. Deste núcleo partiram as idéias para a criação do Museu Paraense, o qual foi inicialmente instalado em um espaço vinculado à biblioteca pública de Belém em 1867, tendo sido inaugurado em 1871 (BITTENCOURT, 2006).

A partir disso é que podemos entender que de forma semelhante ao ocorrido em Belém, a criação de uma biblioteca e de um museu em Mossoró foi o resultado de um projeto não só cultural, mas também eminentemente político e como tal gerou conseqüências, as quais tornaram-se mais nítidas no âmbito do museu de Mossoró, hoje denominado Museu Histórico Lauro da Escóssia.

A biblioteca pública e o museu histórico municipal de Mossoró foram considerados parte integrante "do programa cultural de maior envergadura neste município sob o patrocínio da administração pública" (SANTOS, 1980). Museu e 
biblioteca datam de 30 de setembro de $1948^{14}$, contudo, o primeiro não possuiu um ato oficial que o instituísse e tal fato só veio ocorrer em abril do ano seguinte.

Dos idos de 1948 até 1972 o andar térreo do clube Ypiranga foi o lugar onde se acomodou o acervo do museu municipal, porém, em princípios da década de 1970 o acervo do museu iniciou um nomadismo do qual só foi apartado em fins da primeira metade da década de 1980.

Quando foi percebido que a biblioteca pública estava carente de mais espaço físico, a área escolhida para a ampliação foi justamente a que era ocupada pelo museu. Dessa forma, a partir de 1972 o Museu Municipal de Mossoró foi sacrificado em detrimento de outro projeto e "este sacrifício valeu-lhe, além do fechamento durante cinco anos, o desfalque de algumas coleções cujas peças foram roubadas ou deterioradas pelas más condições de guarda" (SANTOS, 1980).

O acervo do museu municipal ficou encaixotado durante muito tempo, até que com início da administração do prefeito João Newton da Escóssia (1978 - 1982) o museu passou a ocupar alguns cômodos em um local na rua Trinta de Setembro. Novamente o poder público do município atuava sobre a gerência dos acervos que estavam sob a guarda do museu de Mossoró, da mesma forma que, embora em outra administração, contribuiu para o seu fechamento anos antes.

Aliás, nesse aspecto podemos novamente comparar a situação do MHLE com a de outras instituições, como, por exemplo, o Museu Paraense que viveu situações bastante atribuladas em seus primeiros anos e passou à órbita do governo da província no início da década de 1870, quando, talvez até de forma pior do que antes, passou a padecer com a falta de recursos advindos de um império brasileiro em decadência, vindo inclusive, a ser fechado pelos deputados da Assembléia Legislativa em 1888 (SCHWARCZ, 1993).

Sujeito aos avanços e revezes da administração pública, tal qual outras instituições, o acervo do museu de Mossoró sofreu bastante devido, principalmente, ao fato de que

\footnotetext{
${ }^{14}$ A data de criação dessas instituições já demonstra o interesse político dessa iniciativa, uma vez que o 30 de setembro é uma data tradicionalmente muito comemorada no município, pois a historiografia norte-rio-grandense reforça a tese de que nessa data teriam sido libertados todos os escravos da cidade, portanto, uma abolição cinco anos antes da Lei Áurea.
} 
"algumas administrações postas à sua frente, nomeadas apenas por conveniências político-partidárias municipais, não justificaram a ocupação do cargo, contribuindo para a inércia e o abandono a ele dedicado" (SANTOS, 1980).

A participação do jornalista Lauro da Escóssia à frente da direção do museu, ainda na década de 1970, tencionava uma mudança neste quadro. Contudo, Lauro da Escóssia subordinava-se a uma realidade pública institucionalizada que suplantava em muito seu zelo para com o acervo do museu de Mossoró, que anos mais tarde foi batizado de Museu Histórico Lauro da Escóssia em homenagem à incansável luta deste pesquisador.

Lauro da Escóssia pleiteou durante muito tempo a transferência do museu para uma sede mais ampla e quando o governo do estado, através da Fundação José Augusto, acenou com a possibilidade de alojar o museu histórico nas dependências da antiga cadeia pública de Mossoró ele ficou por muito tempo na expectativa da mudança, visto que, aos seus olhos, "com o funcionamento do museu na antiga Cadeia Pública, todo o problema de espaços estaria solucionado, inclusive com condições de se adquirir um maior número de peças, pois então teriam um local mais amplo, para expor o acervo" (CASTRO \& LIMA, 1979).

Construída a partir de 1878, por ordem do então Juiz da comarca Manuel Hemérito Raposo de Melo, e inaugurado apenas em 1880, o prédio da Cadeia Municipal comportava também, só que em seu andar superior, a Intendência de Mossoró. Este é um local de orgulho para o povo mossoroense, que muito se glorifica de terem ocorrido neste espaço a libertação de todos os escravos de Mossoró em 1883 e o $1^{\circ}$ voto feminino da América Latina, protagonizado pela professora Celina Guimarães. O lugar da antiga Cadeia pública foi tombado pelo Patrimônio Nacional em 1980 e em 1984 passou a funcionar como biblioteca pública e museu municipal, partes do, naquele momento instituído, Centro Cultural Manuel Hemérito.

A nova simbiose destas instituições mais uma vez imputou ao museu um papel secundário e, embora em melhor situação do que na rua Trinta de Setembro, os encarregados do museu tinham agora que distribuir seu acervo nas seis salas do andar superior do Centro Cultural. 
Biblioteca pública e museu coabitaram o mesmo espaço físico até o final da década de 1990, pois a partir do ano 2000 o MHLE passou a ocupar na plenitude o prédio da antiga Cadeia Pública. O museu Lauro da Escóssia e evidentemente os profissionais em seu âmbito passaram a enfrentar as intempéries de uma vida solitária e, quase sempre, desprovida de qualquer apoio institucional.

Por ocasião da adequação dos acervos do MHLE ao espaço adquirido com a transferência da biblioteca municipal, o poder público municipal tratou de iniciar obras no prédio já bastante antigo, vindo desta forma a transferir novamente a sede do museu para uma casa nas imediações da antiga Cadeia. Daí porque em 2002 o museu passava

"por reformas há mais de dois anos e por estar com obras concluídas, já deveria ter sido entregue à população. No entanto, um novo contrato para um trabalho imprescindível foi feito: 0 de organização do acervo do museu. Estes trabalhos devem ser finalizados até o início de junho deste ano e possibilitarão uma melhoria substancial ao museu" (O MOSSOROENSE, 2002).

Já se vão quase cinco anos desde que esta reportagem foi feita e, em vários momentos, as intempéries demonstravam estarem sendo suplantadas, com a poeira dos caixotes e prateleiras sendo retirada $e$, parecendo indicar que a reforma iniciada em 2002 inclinava-se a um êxito. De fato, esta situação ainda é a mesma e, por exemplo, a coleção a "reforma" no MHLE.

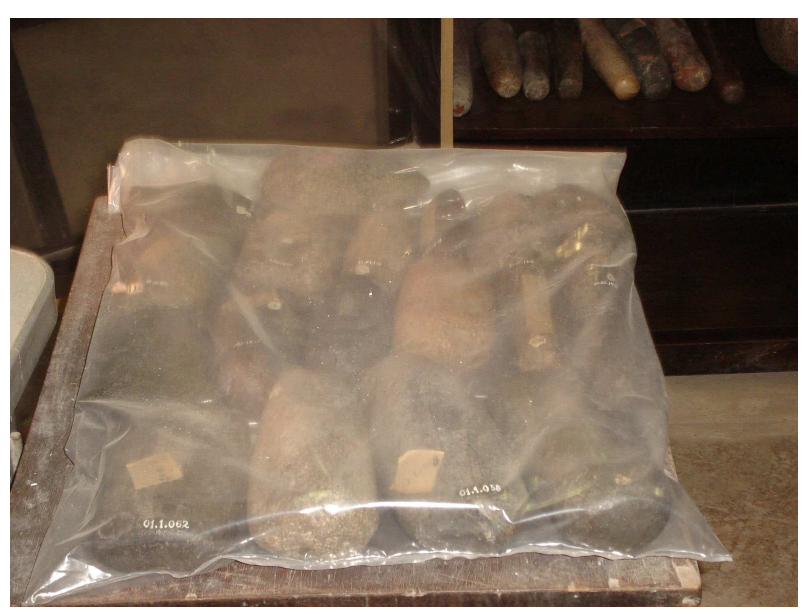

Figura 3. Artefatos líticos ensacados devido arqueológica continua tão encaixotada e empoeirada quanto estava no início da 'reforma' (figura 3), e, até o momento o que passa mais próximo de uma reforma são as camadas novas de tinta que surgem sempre quando se aproxima o principal feriado da cidade, o dia 30 de setembro. 
Parte desta reforma iniciada em 2002 previa a elaboração de um conceito gerador, uma temática, que norteasse a extroversão de parte dos acervos constantes no museu. A 'Proposta conceitual' elaborada em 2003 concretiza esta intenção e define 'A terra e o homem do Oeste potiguar' como o conceito que rege a nova forma de dispor os acervos, concentrando-os:

"Em 10 núcleos expositivos que seriam: geografia, os seres vivos que aqui viveram antes de nós, arqueologia, tentativas de povoamento da região Oeste, o criatório de gado e a formação do povoado, a evolução econômica, o movimento abolicionista, a imprensa mossoroense, o Cangaço em Mossoró e a cultura material" (MAIA, 2004).

Esta forma de disposição visa contemplar as variadas categorias de documentos presentes no Museu Histórico Lauro da Escóssia, categorias que desde o surgimento do museu em 1948, quando possuía 512 peças, têm sido constantemente ampliadas - acrescidas, muitas vezes, pelos objetos que "por não estarem mais em uso, deveriam estar em um museu".

"Entre todas as peças do museu as mais procuradas são as que se relacionam com a Abolição da Escravatura no município e a entrada de Lampião em Mossoró. Quem mais procura estas peças são os alunos de $1^{\circ}$ e $2^{\circ}$ Graus e até mesmo universitários, nas épocas das comemorações" (CASTRO \& LIMA, 1979 - Grifo nosso).

De fato, de todos os materiais presentes no MHLE são os relacionados à abolição da escravidão, que de acordo com a historiografia local teria ocorrido primeiramente em Mossoró e somente cinco anos depois no Brasil como um todo, e à resistência ao bando do cangaceiro Lampião, em 13 de junho de 1927, os mais procurados. Este último fato, por exemplo, é constantemente lembrado pelos moradores locais como exemplo da força e resistência do povo mossoroense.

O poder público municipal há muito propala tais acontecimentos e faz questão de reforçá-los, entre outros aspectos, por meio de grandes festividades anuais e pela nomeação de ruas que lembrem tal acontecimento. Daí porque, 
principalmente, a cultura material que evoque esses acontecimentos é tão procurada e valorizada em detrimento de outros acervos.

Apesar desta preferência pelo público que visita o museu, em meio ao qual hoje se pode incluir o elemento turístico, duas outras coleções são substancialmente importantes e outrora receberam bastante atenção, tendo inclusive um desenvolvimento maior, ao tempo de Vingt-Un (ROLIM, 1994), que são as coleções de paleontologia, hoje contando apenas com quatro espécimes, e arqueologia. A coleção de arqueologia foi detentora durante a década de 1950 de uma "posição de relevo dentre os congêneres do Nordeste. Posteriormente, outros museus da região Nordeste tiveram vantajosamente enriquecidas as suas seções de arqueologia" (ROLIM, 1994).

Embora todas as coleções museológicas sejam passíveis de uma ação ideológica, reporto-me aos materiais arqueológicos justamente por tratar-se de vestígios pertencentes a "sociedades indígenas extintas que viveram em um passado distante, deixando como testemunho de sua existência somente restos materiais" (BARRETO, 2000: 33).

Assim sendo, a coleção arqueológica representa os primeiros produtos culturais das populações que outrora habitaram o Rio Grande do Norte e mais especificamente o Oeste potiguar. Esta coleção faz parte de uma herança que embora impedida de se traçar uma linha de descendência direta com a contemporaneidade, pode sim atuar como elementos de relação com o nosso passado.

\section{A Coleção Arqueológica do Museu Histórico Lauro da Escóssia.}

Pomian conceitua coleção como o conjunto de "objetos naturais ou artificiais mantidos temporária ou definitivamente fora do circuito das atividades econômicas, sujeitos a uma proteção especial e expostos ao olhar do público" (POMIAN Apud RIBEIRO, 1994:194). Podemos acrescentar a este conceito a idéia de que também faz parte da coleção toda a documentação com ela originada e/ou a ela referente (SCATAMACCHIA et al, 1996: 317). 
As coleções são compostas por objetos que se relacionam com o nosso passado e formam, quando parte dos acervos, o que Pomian chamou de 'semióforos', e como tais são dotados de significado (POMIAN Apud RIBEIRO, 1994: 194). Ao usarmos a expressão 'coleção arqueológica' estamos lançando mão de uma generalização tipológica, para referir-se a um conjunto de artefatos formado nas formas primária, secundária e/ou por achados casuais (SCATAMACCHIA et al, 1996). Tal asserção, no caso da coleção arqueológica do MHLE, é feita aos materiais advindos de grupos humanos que habitaram o Rio Grande do Norte, tanto antes quanto depois do contato com os europeus.

Levando-se em conta tal afirmação, podemos dizer que grande parte do conhecimento arqueológico brasileiro possui relação com um período pré-cabralino e também que "a arqueologia feita no Brasil é essencialmente uma arqueologia de sociedades indígenas" (BARRETO, 2000: 33).

Nesta situação, o estudo de uma coleção possui características e enfoques variados, e também, apresenta dificuldades:

"As limitações que o estudo de uma coleção implica são muitas, destacando-se o fato dos vestígios serem tirados do contexto arqueológico, o que impede 0 estabelecimento das relações existentes entre eles. Acrescente-se a isto as dificuldades ligadas a aspectos que dizem respeito a quem organizou a coleção, a quem coletou os vestígios e às condições em que foram coletados" (GUIMARÃES, 1985: 252 - Grifo do autor).

A esta situação, soma-se a constatação de que as coleções mais antigas nas instituições "costumam ser parcamente documentadas, espalhadas ou despidas de integridade" (ROTCHILD \& CANTWEL Apud RIBEIRO, 1994: 196). Esta conjuntura atua de um modo que "enquanto as exposições de museus ganham crescente popularidade em toda a parte com o grande público, as coleções são subusadas ("underused") pela comunidade acadêmica" (ROTCHILD \& CANTWEL Apud RIBEIRO, 1994: 196). Em outras palavras, "as coleções de museus constituem, na atualidade, um dos gêneros de documento menos utilizado pela comunidade científica" (BARCELOS NETO, 1999: 241). 
Contudo, observa-se também que "a existência dessas dificuldades, no entanto, não tira a validade do estudo de coleções" (GUIMARÃES, 1985: 252). Neste sentido, preferimos pensar que

\begin{abstract}
"mesmo tendo o seu potencial informativo comprometido, a maioria das coleções museológicas pode ter um aproveitamento científico e deve ter uma divulgação adequada, pois, como todo vestígio material do passado constitui um patrimônio cultural nacional. São produtos de atividades passadas e cabe ao pesquisador estabelecer os parâmetros da sua representatividade cultural" (SCATAMACCHIA et al, 1996: 318).
\end{abstract}

Destarte, cabe ressaltar que o estudo de coleções arqueológicas não só no Brasil, mas no restante do mundo teve um caminhar diferenciado, indo desde a principal fonte de pesquisa para os que trabalhavam em arqueologia até ao descrédito dos que trabalhavam com coleções. Na atualidade percebe-se que "explorar o potencial cientifico de coleções representa uma opção metodológica defendida por diferentes vertentes de pesquisa" (GOMES, 2002: 15).

Esta mudança de concepção possui origem em percepções, ou linhas teóricas, que creditam valor científico a coleções obtidas por meio de métodos rigorosos, sem, é claro, desconsiderar os outros tipos de coleções que agregam 'semióforos' e são desprovidas dos critérios da ciência moderna, este tipo de coleção, tal qual a primeira, também se presta a generalizações e a resolução de questões no âmbito das investigações arqueológicas.

\footnotetext{
"Desta forma, espera-se estar chamando a atenção para a existência dos acervos que os museus abrigam, para que o seu potencial, assim como o da cultura material de modo geral, seja valorizado como fonte de informação, fazendo deles uma ferramenta a serviço do conhecimento" (RIBEIRO \& VERTHEM Apud MORALES, 1999: 220 - Grifo do autor).
}

A coleção arqueológica do MHLE é a mais expressiva do estado, embora outrora também tenha sido a mais numerosa (gráfico 1). Os artefatos desta coleção computam aquisições advindas das quatro mesorregiões do Rio Grande do Norte (figura 4). Os materiais são oriundos de aproximadamente vinte e um municípios 
(figura 5), isto de acordo com o levantamento do acervo do museu feito no ano de 2002, onde não aparece o local de origem de 23\% das 286 peças catalogadas na época, hoje este número é de 283.

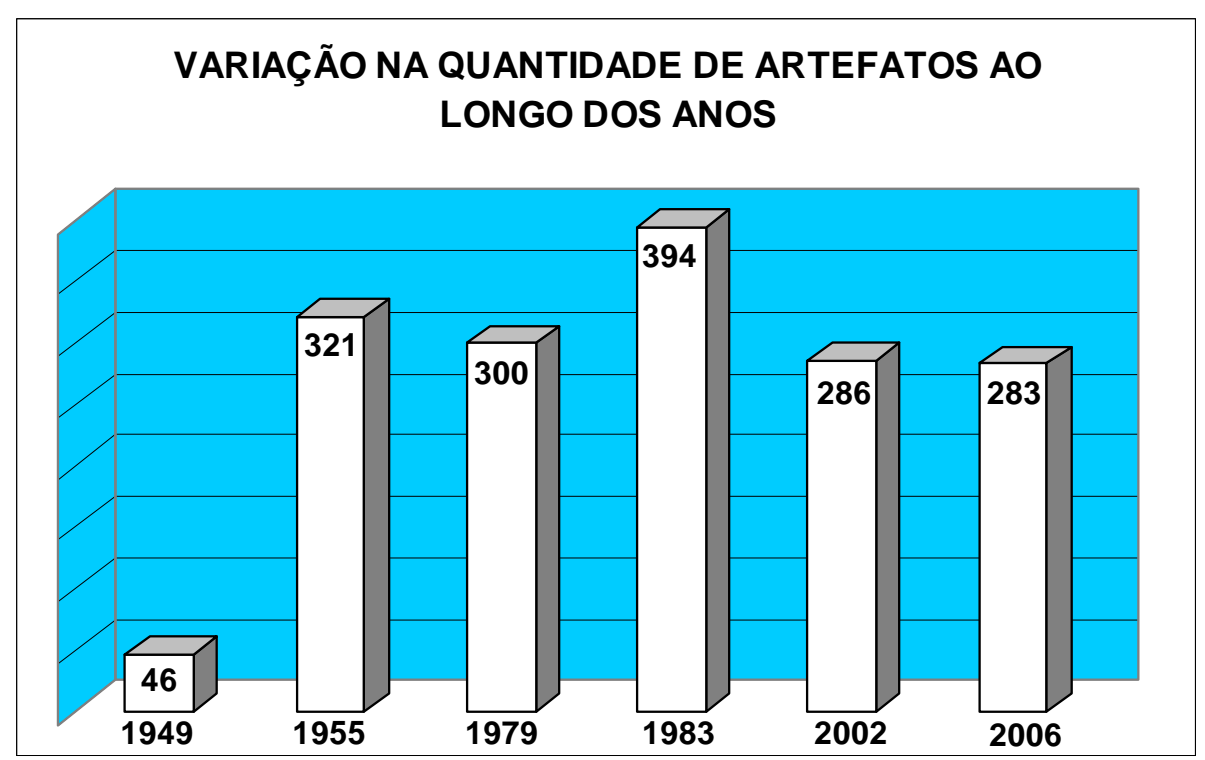

Gráfico 1. Variação na quantidade de peças na coleção arqueológica do MHLE ao longo dos anos.

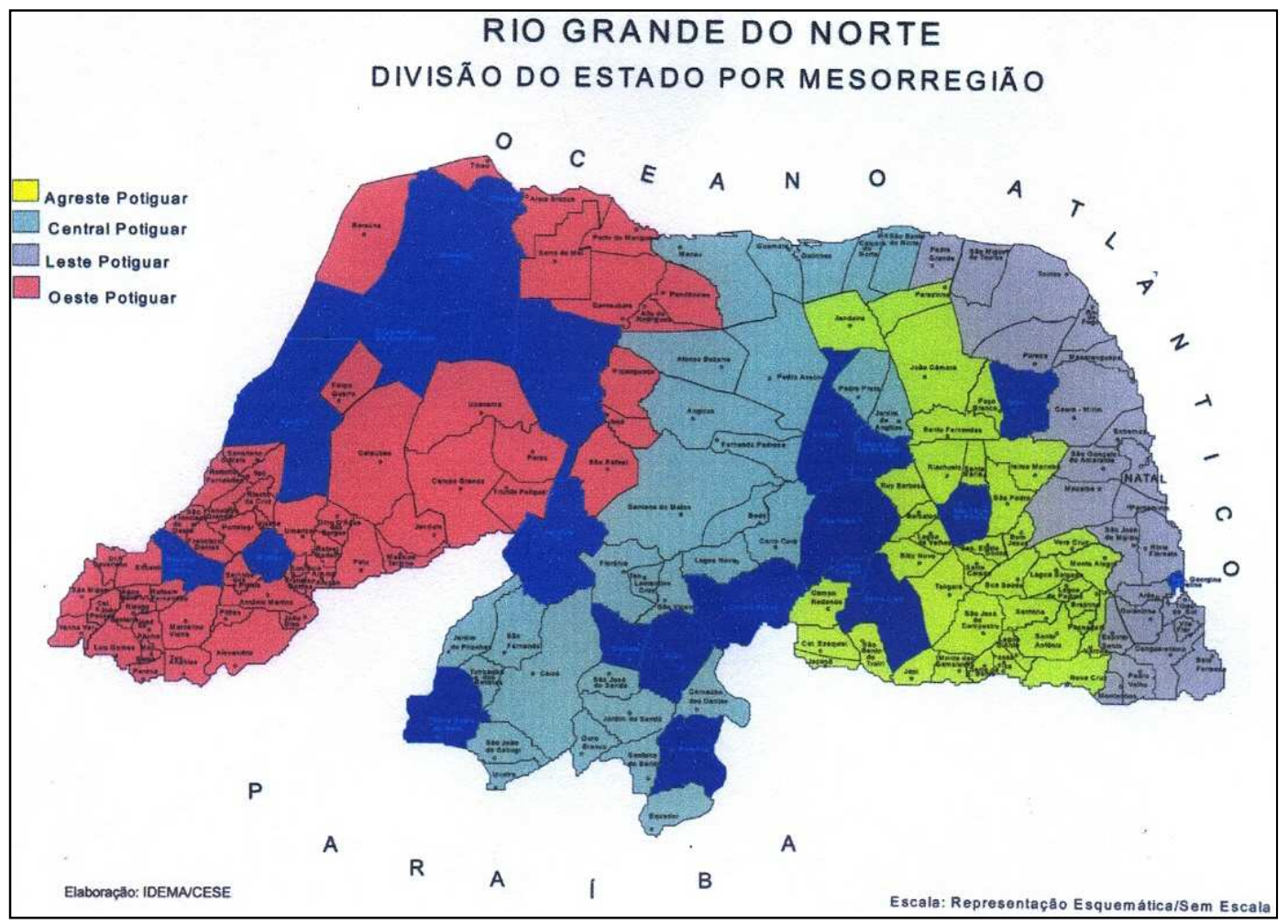

Figura 4. Mapa com os municípios de origem de peças da coleção arqueológica do Museu Histórico Lauro da Escóssia. 


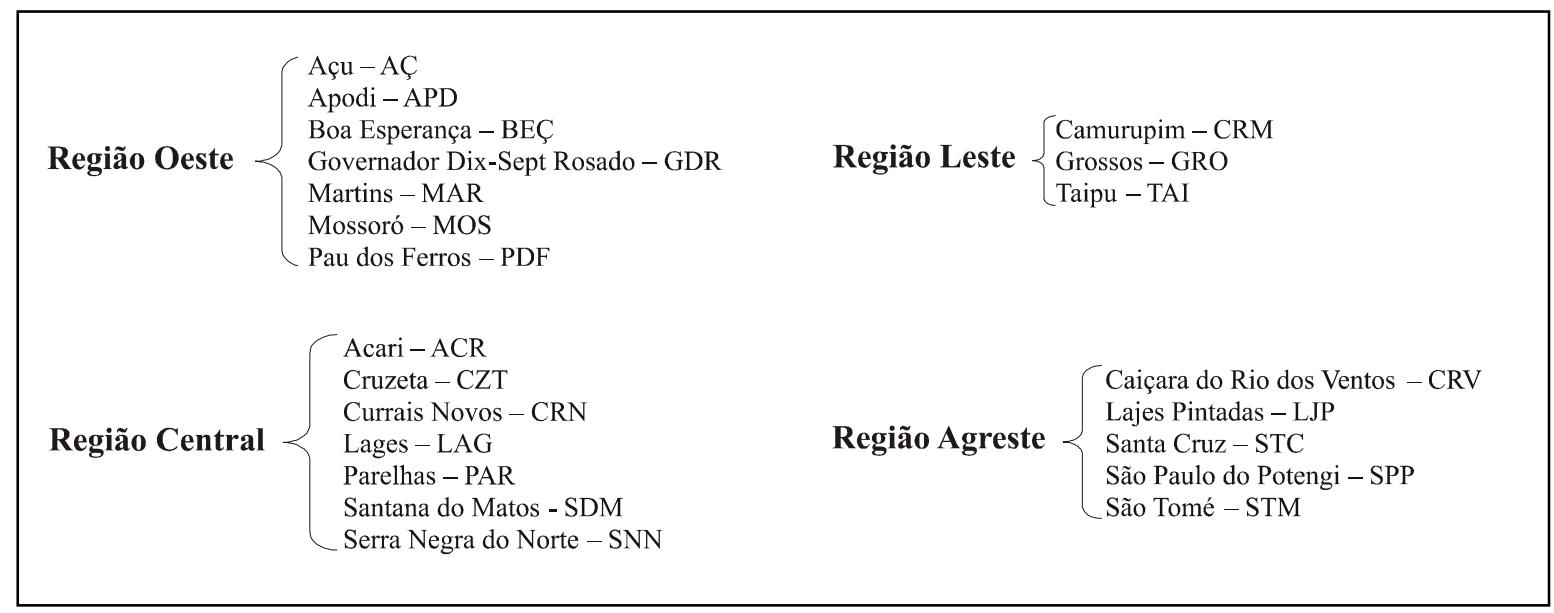

Figura 5. Municípios/origem dos artefatos da coleção arqueológica do MHLE e respectivas siglas adotadas, durante a pesquisa de dissertação.

As localidades que mais contribuíram com materiais para esta coleção do Museu Lauro da Escóssia, curiosamente são as menos pesquisadas no Rio Grande do Norte até hoje, diga-se de passagem, que a grandeza do potencial do estado para materiais arqueológicos é inversamente proporcional à quantidade de pesquisas já executadas.

Somando-se os materiais advindos de Apodi, Mossoró, Grossos, Pau dos Ferros e Martins tem-se simplesmente mais da metade das atuais 220 peças da coleção arqueológica do Museu Lauro da Escóssia com origem conhecida. Não bastasse isto, Caiçara do Rio dos Ventos, Lajes, Taipu, São Paulo do Potengi, São Tomé, Lajes Pintadas e Santa Cruz foram os locais de origem de aproximadamente $25 \%$ das peças desta coleção.

Ao todo tem-se então 283 artefatos, uma análise preliminar dos dados, indica ser a menor quantidade de peças que o museu possuiu desde a década de 1950, época em que a coleção foi contabilizada pela segunda vez. A coleção é composta basicamente por três categorias de artefatos: líticos polidos, líticos lascados e artefatos cerâmicos; há ainda a ocorrência de um percentual de materiais não arqueológicos, mas que foram agregados à coleção 'em tempos imemoriais' (gráfico 2). 


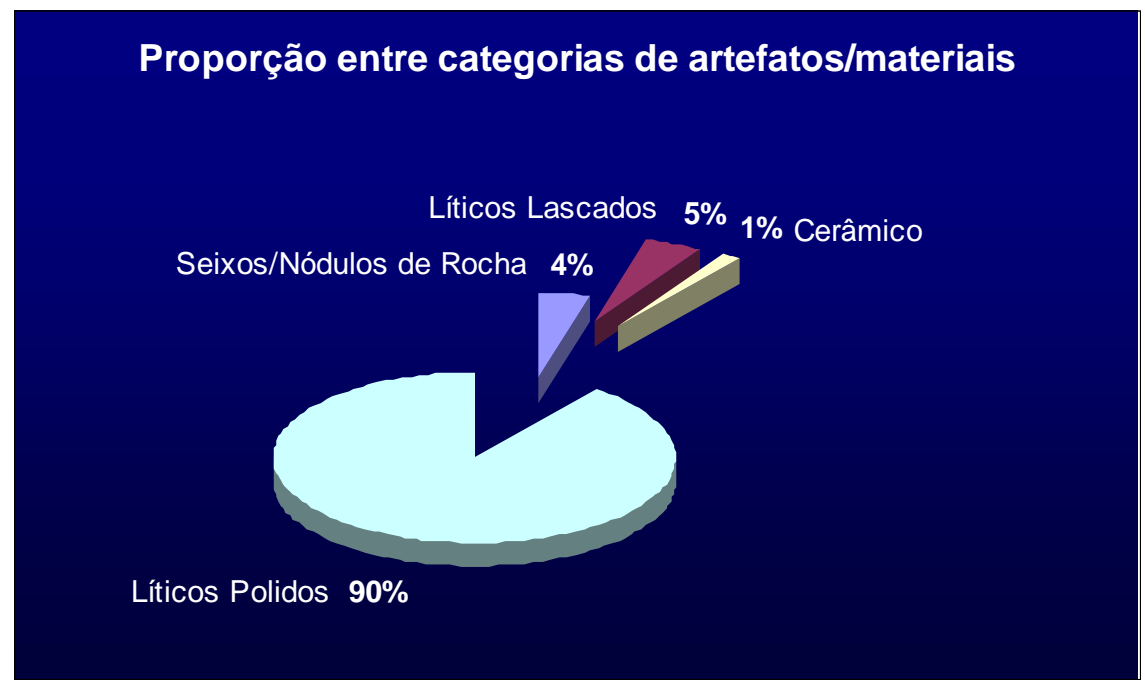

Gráfico 2. Proporção entre categorias de artefatos/materiais na coleção arqueológica do MHLE.

Conforme podemos observar no gráfico, a grande maioria dos artefatos (cerca de $95 \%$ ) são líticos ${ }^{15}$, subdivididos em lascados e polidos, estes últimos a julgar por seus caracteres morfofuncionais ${ }^{16}$ podem ser agrupados nos seguintes conjuntos artefatuais: lâminas de machado, cunhas, cinzéis, mós, mãos de mó, almofarizes, pilões e batedores - esféricos e semi-esféricos. Nestes conjuntos sobressaem-se as lâminas de machado (figuras 6 e 7), que são associadas a um uso utilitário, muito embora, dado a variabilidade destes artefatos nos seja possível inferir "que deveriam estar ligadas a momentos e utilizações diferentes, que pela natureza da amostra não podemos resgatar no momento" (SCATAMACCHIA et al, 1996: 322).

\footnotetext{
${ }^{15}$ A bibliografia básica usada para trabalhar com esses artefatos foi: 1) LAMING-EMPERAIRE, Annette. Guia para o estudo das indústrias líticas da América do Sul. Curitiba: EDUFPR, 1967; 2) LAROCHE, Gaston, LAROCHE, Adjelma Soares e Silva. Ensaios de classificação tipológica sobre as pontas de arremessos e outros objetos líticos da tradição Potiguar. In: Suplemento, n. 15. Natal: UFRN, 1983; 3) PROUS, André. Os artefatos líticos: elementos descritivos classificatórios. In: Arquivos do Museu de História Natural - UFMG. Belo Horizonte: UFMG, v. 11, 1986/90; 4) PROUS, André, et al. Os machados pré-históricos no Brasil - descrição de coleções brasileiras e trabalhos experimentais: fabricação de lâminas, cabos, encabamentos e utilização. In: CANIDÉ: Revista do Museu de Arqueologia de Xingó. n. 2. Aracaju: UFS, dezembro de 2002.

${ }^{16}$ Por morfofuncional neste caso, entende-se características advindas do emprego de técnicas que implicaram no desenho da peça (forma) contribuindo para a formação de um tipo artefatual passível de inferência funcional (cultural).
} 


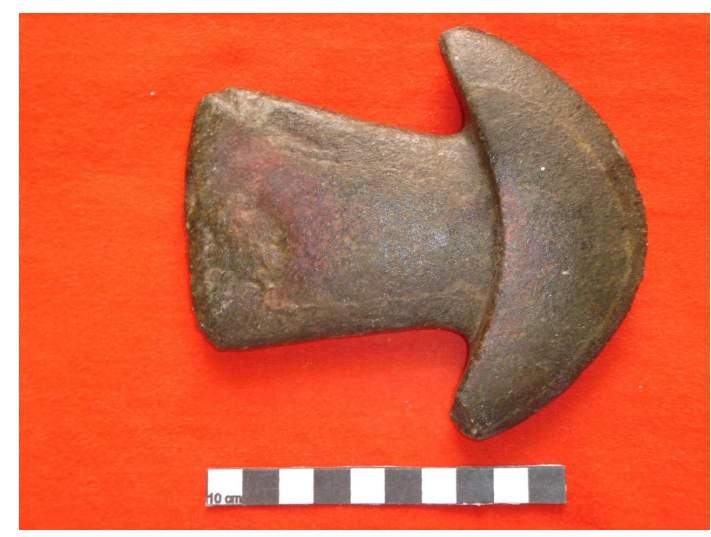

Figura 6. Lâmina de machado semilunar.

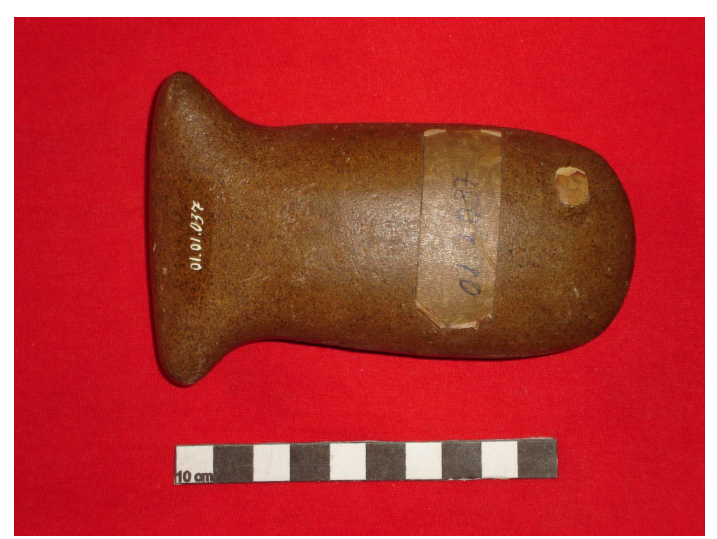

Figura 7. Lâmina de machado.

As matérias-primas de onde se originaram os artefatos polidos são: arenito, basalto, diabásio, granito e quartzo, sendo que a matéria-prima básica em $70 \%$ dos casos é o granito, rocha dominante nas regiões central e oeste do Rio Grande do Norte (DIAGNÓSTICO estrutural, 1976). No que diz respeito ainda ao material lítico polido, existe também na coleção algumas contas de colar e um tembetá (adorno labial).

Já no caso do material lítico lascado, há no museu Lauro da Escóssia a maior coleção de pontas de projéteis do estado (figura 8). Em linhas gerais, podemos caracterizá-las como bifaciais, pedunculadas e com aletas, sendo que alguns casos apresentam serrilhas; o tamanho, assim como os materiais de que são feitas, varia bastante - o primeiro, ficando entre $3 \mathrm{~cm}$ e $13 \mathrm{~cm}$, e o segundo, entre quartzo, sílex e calcedônia.

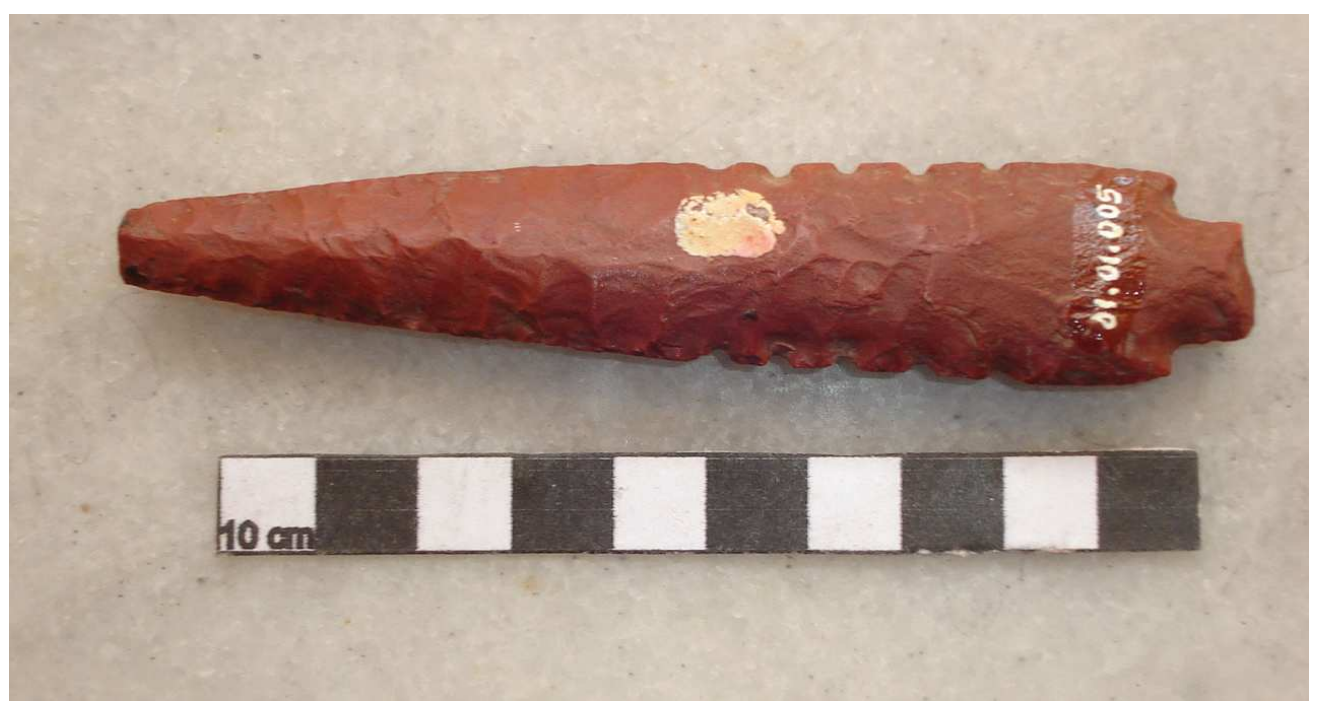

Figura 8. Ponta de projétil que integra a coleção arqueológica do MHLE. 
Esta coleção foi alvo de um pequeno ensaio da professora Gabriela Martin, no início dos anos 1980, na época ela apontava que o acervo era formado por "pontas talhadas, lâminas de machado polidas, mós, almoxarifes e mãos de almoxarifes, além de contas de colares de quartzo verde" (MARTIN, 1983: 75). De certa forma, podemos dizer que os estudos feitos, sob alguns aspectos, referendam o trabalho feito na década de 1980. Sendo que em suas conclusões Martin salienta que "ao significativo [número?] de almoxarifes e moinhos manuais, deviam acompanhar restos de cerâmica que, infelizmente, não foram recolhidos na época do achado" (MARTIN, 1983: 74).

De fato, a menor quantidade de peças na coleção arqueológica do MHLE fica por conta das cerâmicas ${ }^{17}$, são cinco cachimbos, ou mais precisamente cinco fornilhos de cachimbo que apresentam decoração incisa e excisa, havendo em um dos artefatos a elaboração de motivos geométricos em uma das superfícies (figura 9). Essas peças, tal qual as demais que integram a coleção do Lauro da Escóssia, estão, no que concerne à forma e decoração, parcialmente comprometidas - com marcas de sucessivos tombos, rachaduras e até resquícios de uma produto lustroso aplicado para que os objetos 'brilhassem mais'. Estes são elementos que evidenciam a forma como vem ocorrendo o gerenciamento do acervo, contribuindo, inclusive, para o desaparecimento de peças como um esplêndido vasilhame cerâmico (figura 10), proveniente de Jucurutu/RN, com decoração em sua parte interna e em suas bordas, como que a se contrapor a idéia de que os habitantes do sertão eram artífices de "uma cerâmica grosseira (...) mal cosida, com grande quantidade de grânulos" (SILVA, 1983: 82).

\footnotetext{
${ }^{17}$ A bibliografia básica usada para trabalhar com esses artefatos foi: 1) ALVES, Márcia A. Estudo técnico em cerâmica do Brasil. In: Revista do Museu de Arqueologia e Etnologia da USP. n. 4. São Paulo: EDUSP, 1994; 2) LUNA, Suely. O sítio Sinal Verde - São Lourenço da Mata, PE. Uma aldeia pré-histórica na zona da mata pernambucana. In: CLIO. Série Arqueológica. Recife: UFPE, v. 1, n. 7, 1991; 3) OLIVEIRA, Cláudia A. Abordagens teóricas dos grupos pré-históricos ceramistas no Nordeste. In: CANIDÉ: revista do Museu de Arqueologia de Xingó. Aracaju: UFS, n. 1, dezembro de 2001; 4) SEMINÁRIO de ensino e pesquisas em sítios cerâmicos. Terminologia Arqueológica Brasileira para Cerâmica. Manuais de Arqueologia, n. 1. Paraná: UFP/CEPA, 1966.
} 


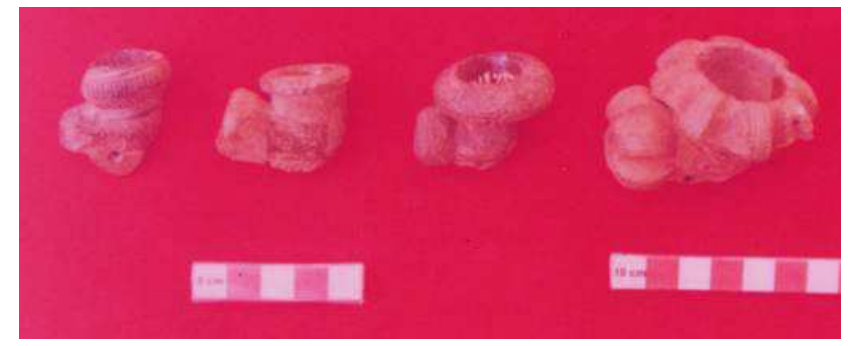

Figura 9. Fornilhos de cachimbo da coleção arqueológica do MHLE.

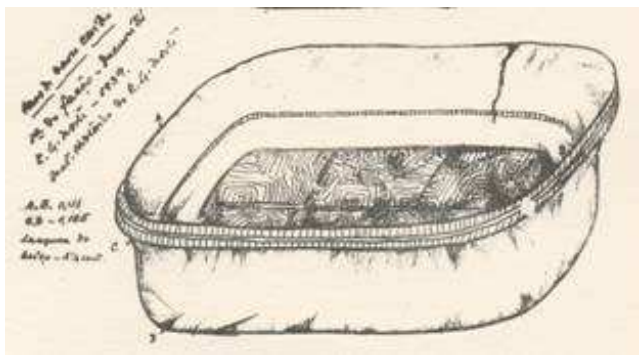

Figura 10. Vasilhame cerâmico de Jucurutu/RN.

Lamartine/1983.

Contudo, retomando o foco sobre os caracteres morfofuncionais dos artefatos, podemos observar que os horizontes culturais 'horticultor e caçadorcoletor' compõem os tipos de grupos humanos mais facilmente associados à manufatura das peças arqueológicas desta coleção. Grupos dos períodos Arcaico e Formativo $^{18}$, que, principalmente neste último caso, já estariam afeitos à lida com vegetais, isto, a julgar pelo grande número de instrumentos que "com formas semelhantes ocorrem em várias partes do mundo e são utilizados como indicador de início de manejo e processamento de vegetais" (TENÓRIO, 2000: 265). Um exemplo disto são as mós (figura 11), que aparecem na coleção do MHLE e são assim caracterizadas por Tenório:

"A mó pode ser descrita como uma pedra de superfície plana, ou então ligeiramente côncava em virtude do uso, onde era colocado o vegetal para ser esmagado por pressões e pequenas batidas. $O$ vegetal seria esmagado por movimentos circulares e laterais através da utilização da mão-de-mó" (2000: 266).

\footnotetext{
${ }^{18}$ Segue-se neste caso, a mesma conceituação para os períodos Arcaico e Formativo adota em: DE BLASIS, Paulo A. D. Indicadores da transição do arcaico para o formativo na região montanhosa do médio vale do Ribeira. In: TENÓRIO, Maria Cristina (Org.). Pré-história da Terra Brasilis. Rio de Janeiro: EDUFRJ, 2000.
} 


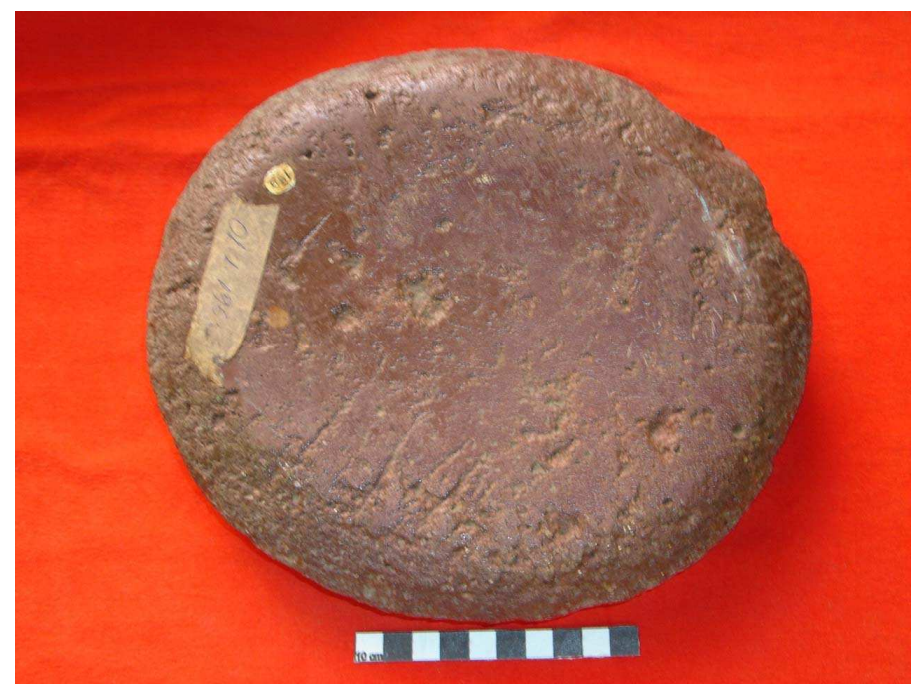

Figura 11. Instrumento passivo, tipo mó - coleção arqueológica do MHLE.

A dieta com forte presença de vegetais pode ser relacionada, por exemplo, com os habitantes do sítio do Góis (Apodi/RN), lugar de origem de muitos dos objetos. Entretanto, esta não parece ter sido a única variante protéica, já que a coleção também apresenta pontas de projéteis (figura 12) e estas são comumente associadas ao cabedal por excelência dos grupos de caçadores-coletores que poderiam associar a caça com de vegetais, ou abster-se dos vegetais em prol apenas da caça.

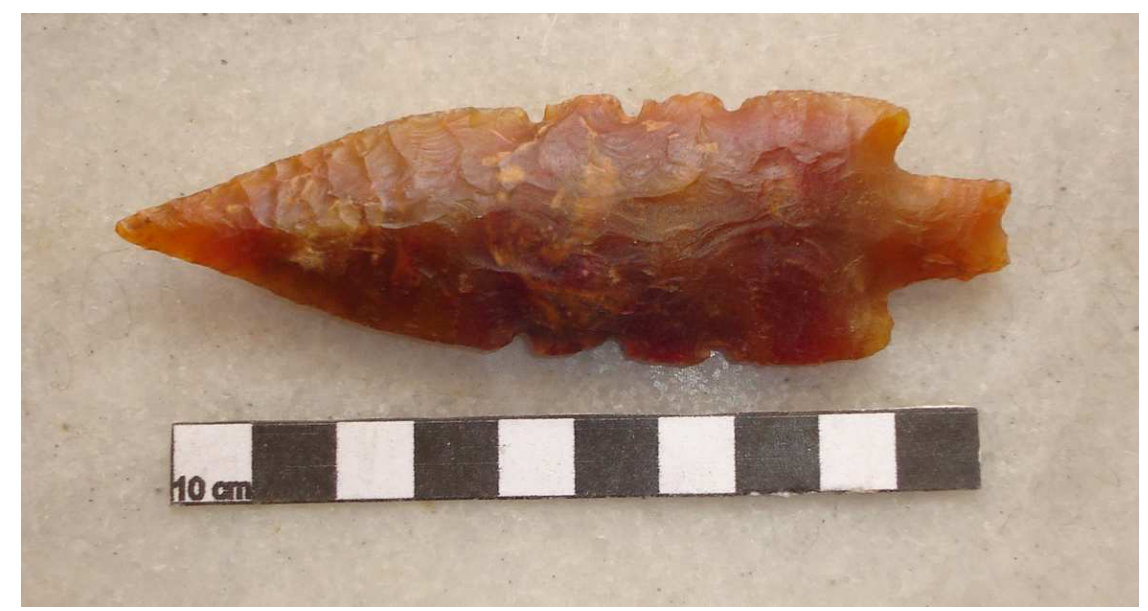

Figura 12. Ponta de projétil, coleção arqueológica do MHLE.

Horticultores, caçadores, ou os dois juntos, as sociedades que executaram estes implementos para melhorar suas condições de vida também elaboraram objetos de cunho (porque não?) cerimonialista, conforme pode ser 
inferido a partir dos cachimbos indígenas encontrados na coleção do Museu Lauro da Escóssia, ricamente decorados, estas peças cerâmicas estão intrinsecamente associadas às práticas culturais dos grupos que os conceberam. Hábitos culturais como, por exemplo, o uso de colares (figura 13) ou de tembetá (figura 14), utilizados praticamente em todas as sociedades indígenas brasileiras e que são dotados, em muitos casos, de um sentido de beleza estética bastante vívido. O uso destes adornos atua, principalmente, como elemento de diferenciação social e podem, também, serem observados enquanto parte da coleção arqueológica do MHLE.

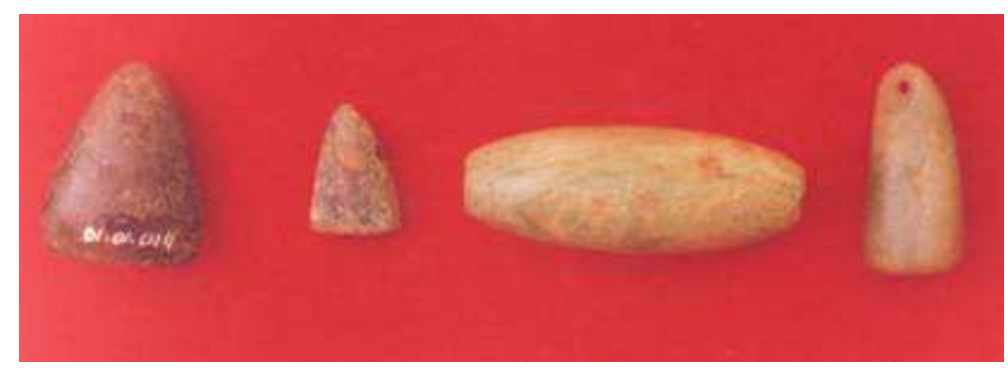

Figura 13. Contas de colar, coleção arqueológica do MHLE.

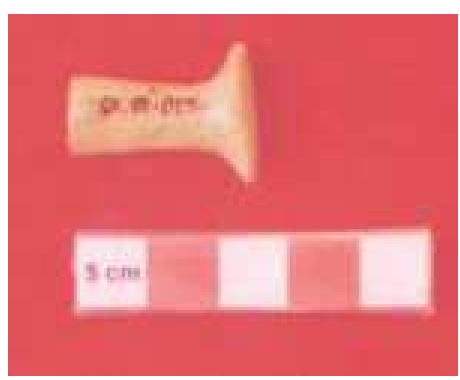

Figura 14. Adorno labial, Tembetá coleção arqueológica do MHLE.

Em vários casos os usos das peças desta coleção podem ser apenas inferidos a partir de relatos etnográficos. Tal acontecimento surge justamente porque de uma maneira geral "a maioria dos acervos museológicos carecem de dados que os contextualizem" (RIBEIRO, 1994: 193), ou então, em nosso caso mais especificamente, devido ao "fato dos vestígios arqueológicos não terem se originado de uma escavação sistemática, onde cada vestígio deve ser criteriosamente considerado" (GUIMARÃES, 1985: 253). Isto implica em abordarmos a situação de como estes artefatos ingressaram no Lauro da Escóssia, uma vez que "a análise do processo de formação de uma coleção é um dado importante a ser considerado para ajudar na compreensão do conjunto de objetos" (SCATAMACCHIA et al, 1996: 318).

Trazidos à mão livre, em carro de mão, embalados em jornal, colocados dentro de uma caixa, ou simplesmente expostos ao tempo, é assim que parecem ter adentrado a quase totalidade dos materiais arqueológicos no Museu Lauro da Escóssia. Algumas vezes, o depositante (ou doador) parece ter chegado ao museu, 
desatulhado 'as pedras e os cacos' e logo em seguida saído, sem que o funcionário da instituição tivesse tempo se quer para anotar seu nome e o lugar de onde vinham aquelas peças, mas a tempo de escapar, caso o funcionário não aceitasse ficar com aquelas 'coisas velhas'.

De acordo com o relatório feito no ano de 2002 pelo museólogo Hélio Oliveira, as formas de aquisição dos artefatos arqueológicos no Museu Histórico Lauro da Escóssia aparecem como sendo apenas duas: a compra e a doação. $\mathrm{O}$ interessante destas variantes é justamente porque, embora as doações sejam a grande maioria, a compra de peças foi o modo como $32 \%$ dos bens, de 192 que apresentam a forma de aquisição, entraram no MHLE (gráfico 3).

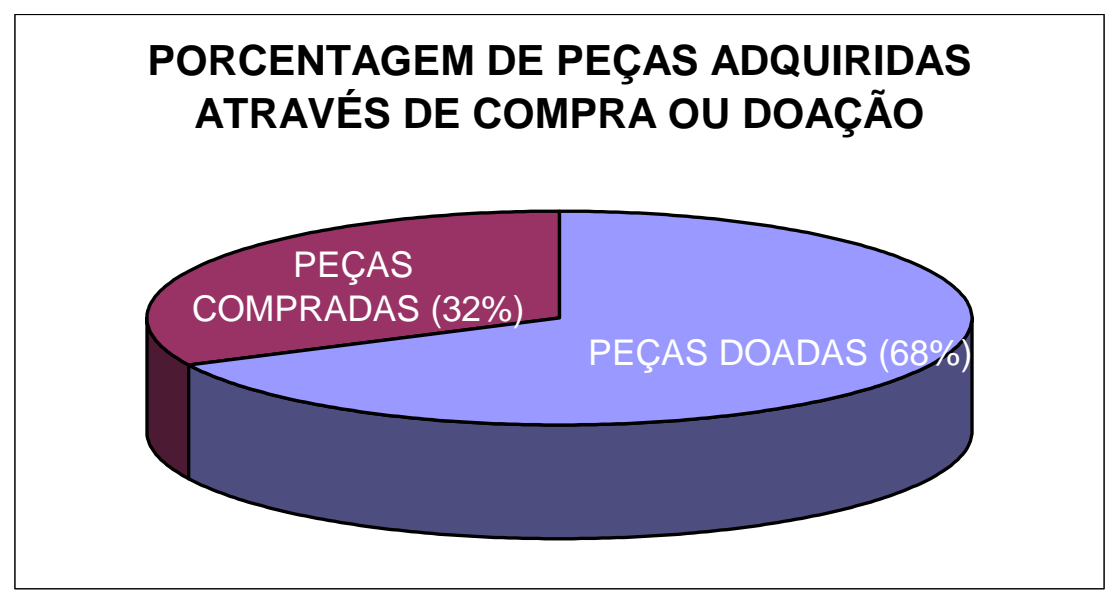

Gráfico 3. As principais formas de aquisição das peças arqueológicas do Museu Lauro da Escóssia, segundo relatório feito em 2002.

Outro dado que também chama a atenção nesta relação entre materiais comprados e materiais doados é que a quantidade de doadores é bastante ampla, superando a casa dos 30 , em comparação com o pouco mais de dois terços da coleção adquirida por meio da doação. Enquanto isto, o universo de peças adquiridas através da compra é repartido apenas entre duas pessoas: o senhor Oswaldo Lamartine de Faria e o Doutor Jonas de Oliveira Leite.

O perfil dos doadores da coleção vai desde agricultores até homens de letras, contudo, ao menos como forma de se traçar um perfil dos que tributaram peças ao Museu Lauro da Escóssia, vemos o senhor Oswaldo Lamartine como o 
mais apropriado, uma vez que 47 peças da atual coleção arqueológica saíram de sua coleção particular. Inclusive, recentemente, em uma entrevista Oswaldo Lamartine confidenciou que, na realidade, as peças que ele remeteu ao museu foram por ele compradas com o objetivo de que fossem doadas ao museu. Assim sendo, parte do material que aparece no relatório de 2002 como tendo sido comprado, na realidade foi doada e configura então um novo padrão para a coleção arqueológica do MHLE, desta fez com $84 \%$ das peças tendo sido doadas e $16 \%$ compradas.

De qualquer modo, de acordo com os atuais registros, o senhor Lamartine é quem mais forneceu peças para a formação da coleção arqueológica. Oriundo do sertão norte-rio-grandense, Oswaldo Lamartine é descendente "das velhas e nobres famílias patriarcais e povoadoras do Seridó" (SEREJO, 2002: 25). Oswaldo Lamartine estudou no colégio Pedro II, Rio de Janeiro, depois foi ao Recife e retornou ao Rio de Janeiro para em seguida vir a completar seus estudos na Escola Superior de Agricultura de Lavras, Minas Gerais - onde conheceu "um amigo que escolheu para ser como irmão a vida inteira: Vingt-Un Rosado" (SEREJO, 2002: 26).

Tido por pesquisadores brasileiros, por exemplo, Gilberto Freyre, como sendo um grande etnógrafo, Oswaldo Lamartine mostra-se uma exceção devido ao seu recato no sertão do Rio Grande do Norte, de onde não desejou sair para atender a convites de conferências a serem proferidas em locais como o Museu Nacional, Rio de Janeiro. Citado por Estevão Pinto, autor de obras sobre etnografia indígena, Oswaldo Lamartine parece ser aquele que "coletou, ordenou e classificou as primeiras peças líticas para um estudo da arqueologia do sertão" (SEREJO, 2002: 43).

Pensando provavelmente nesta arqueologia é que Oswaldo Lamartine reuniu uma relevante coleção, que se via constantemente acrescida por materiais provenientes de lugares "onde 0 sr. $O$. Lamartine tem parentes que the presenteavam com pedras de corisco" (SOARES, 1982: 26 - Grifo da autora).

Oswaldo Lamartine parece ter sido um daqueles pesquisadores que, ainda 'à moda do século XIX', coletava e classificava os objetos para, após ter tirado suas conclusões, guardá-los em um museu. Esta última tarefa não se tornou difícil 
tendo em vista a sua grande amizade com Vingt-Un Rosado, um dos maiores, senão o maior dos incentivadores da criação e manutenção do Museu Mossoroense.

A forma de aquisição das peças de uma coleção, seja ela arqueológica ou não, é condição 'sine qua non' para um bom manuseio do material e um melhor entendimento deste quando estiver em exposição. Descontextualizado, sem informações sobre o que o cercava na hora de sua fabricação e no momento em que deixou de ser usado, assim como, sem as informações sobre quem o executou e para que o executou, o objeto passa à esfera de um óbice, ou seja, tornar-se um empecilho, pois não faculta uma visão mais ampla a seu respeito.

Destarte, percebe-se que o princípio de pesquisar os materiais para depois expô-los, adotado pelos primeiros museus brasileiros e no Rio Grande do Norte pelo Museu Câmara Cascudo, durante o período em que funcionava o Departamento de Antropologia desta instituição, não condiz com a realidade do Museu Histórico Lauro da Escóssia. Dessa forma, não só a exposição, mas também o trato com os materiais arqueológicos neste museu apresentam especificidades que, de uma forma mais direta, podem ser representadas pela forte vinculação que, dentro desse contexto, eles assumiram em relação à produção historiográfica local, principalmente, por tratarem-se de artefatos relacionados aos grupos ágrafos norterio-grandense.

\section{O que nos conta a produção historiográfica local sobre os grupos autóctones do solo potiguar.}

A produção historiográfica sobre o Rio Grande do Norte foi desde os primeiros trabalhos fortemente influenciada por uma concepção tradicional de história, a mesma que reforça um passado brasileiro homogêneo e onde distingui-se referências patrimoniais como, por exemplo, igrejas ou casas grande, em detrimento, entre outros, dos bens indígenas. As duas obras que inicialmente tentaram sintetizar a história do estado mostram-se teórica e cronologicamente ainda muito próximas desta historiografia, assente em bases positivistas. 
Sob essa perspectiva é que aparece a 'História do Rio Grande do Norte', de Augusto Tavares de Lyra, uma obra "com que o Instituto Histórico e Geográfico Brasileiro comemorou o centenário de nossa independência, em 1922" (LYRA, 1998:9). Nesta, a idéia de uma história formada a partir de três 'raças' - a saber, o índio, o negro e o branco, ressaltando-se um determinado grau de superioridade do 'branco colonizador', vê-se contemplada. No livro de Tavares de Lyra, há um amplo destaque aos elementos da colonização européia, ficando outras etnias circunscritas a alguns 'lampejos históricos'. Assim sendo, e, no que diz respeito especificamente à figura do indígena norte-rio-grandense, podemos dizer que este possui pouca relação com a história do Rio Grande do Norte.

No início do livro o elemento indígena aparece enquanto 'mercador de pau-brasil' e aliado dos corsários franceses, que devido aos intentos comerciais sabiam cativar melhor os povos autóctones. Segue-se então um vácuo, quebrado esporadicamente por algumas ações individuais de elementos de destaque entre os grupos indígenas, inclusive, no que concerne à fundação da cidade do Natal onde o papel desempenhado pelos indígenas não estava mais do que na hora de acontecer, pois era preferível ser subjugado a enfrentar os revezes de um conflito com os colonizadores (LYRA, 1998: 16).

Outra obra veiculada também durante o centenário da independência do Brasil, a 'História do Estado Rio Grande do Norte', de Rocha Pombo, não difere muito da escrita por Tavares de Lyra, principalmente no que tange à elaboração do ideal de formação étnica brasileira. Para Rocha Pombo a união de dois elementos exógenos e um autóctone formam o triângulo étnico da nação brasileira do qual sobressaiu a etnia branca européia (POMBO, 1922). A noção de história esboçada então em suas páginas, é a mesma que resultou da argüição do Instituto Histórico e Geográfico Brasileiro aos seus sócios em 1843:

\footnotetext{
"A resposta vencedora foi a de Von Martius. Ele afirmava que, para se escrever a História do Brasil devia-se, em primeiro lugar, atentar para a formação étnica do Brasil e a contribuição do Branco, do negro e do índio para a formação da população brasileira. Enfatizou o papel dos portugueses no descobrimento e colonização, compreendido somente em conexão com suas façanhas marítimas, comerciais e guerreiras" (ABUD, 2002: 30).
} 
A partir destes postulados, Rocha Pombo escreve uma história do Rio Grande do Norte conspícua a uma história do Brasil que é, em seus auspícios, uma história de Portugal e uma história do elemento europeu branco, conforme pode ser notado em seus dois primeiros capítulos: "Antecedentes históricos" e "Antes da conquista". $\mathrm{Na}$ consecução da obra o indígena, quando notado, é elemento secundário aparecendo à guisa de um contexto exótico, embora, às vezes, sejam ressaltadas suas qualidades temperas como um instinto heróico (POMBO, 1922: 21), mas isso não ocorre sem propósito, pois no ideal de nação brasileira elaborado em fins do século XIX "o componente de nobreza da nossa formação viria do índio, que não teria aceitado a escravidão, que enfrentava bravamente os obstáculos da floresta e os inimigos" (ABUD, 2002: 37).

A presença de etnias indígenas no Rio Grande do Norte, nas sínteses históricas produzidas por Rocha Pombo e Tavares de Lyra, não ocorre antes das Navegações, época em que estes iniciam o 'comércio' com estrangeiros, e nem tampouco vai além dos confrontos ocasionados pela 'Guerra dos Bárbaros'19.

Embora de épocas distintas e posteriores às primeiras sínteses históricas sobre o Rio Grande do Norte, as histórias produzidas por Câmara Cascudo (1955) e Suassuna \& Mariz (2002) apresentam algumas semelhanças com as obras escritas no início do século $\mathrm{XX}$, entre outros aspectos, no concernente ao fato de que "os grupos indígenas são mencionados apenas no início da colonização, na fase da conquista, e como justificativa para explicar a introdução de escravos africanos" (BITTENCOURT, 2002: 88 - 89).

Contudo, é nos trabalhos destes pesquisadores que se encontram as únicas menções à presença indígena no estado ainda no século XIX, uma vez que de acordo com as duas obras "a última informação oficial data de 1844, proveniente de um arrolamento feito pelo Chefe de Polícia, João Paulo de Miranda, com um registro de 6.795 índios" (MARIZ \& SUASSUNA, 2002: 180). Além disto, ambos os textos concordam que "depois de 1850 rareiam as informações e as referências são realmente aos mestiços" (CASCUDO, 1986: 44).

\footnotetext{
${ }^{19}$ Sobre a Guerra dos Bárbaros, leia-se: TAUNAY, Affonso E. A Guerra dos Bárbaros. Mossoró: Fundação Vingt-Un Rosado, 1995.Série C, v. 863. (Coleção Mossoroense)
} 
De maneira geral essas quatro histórias do Rio Grande do Norte sintetizam o caleidoscópio cultural existente tanto à época da chegada dos europeus quanto no decurso de boa parte da obra colonizadora por meio do binômio Tupi Tapuia, respectivamente, etnias do litoral e do interior, ou sertão.

O exame da historiografia norte-rio-grandense evidencia uma mesma tendência manifesta em obras que buscam sintetizar a história do país, a ausência de itens e capítulos dedicados à ocupação pré-histórica do Brasil. Isto tanto para os autores ditos 'clássicos', que escreveram "obras de visão geral sobre a história do Rio Grande do Norte, escritas na primeira metade do século XX" (MONTEIRO, 2002: 15), quanto para os pesquisadores mais novos, responsáveis "por obras que tratam de temas específicos, produzidas mais recentemente" (MONTEIRO, 2002:15).

As 'histórias' do Rio Grande do Norte até hoje escritas não contemplam o período ágrafo em solo potiguar. Podemos dizer, a partir das palavras de Câmara Cascudo, que a história do Rio Grande do Norte começa antes da atribuição de um quinhão de terra a João de Barros, sendo esta a história dos traficantes franceses, dos náufragos espanhóis e, principalmente, da nação indígena que circundava as margens do Rio Grande (atualmente chamado de Potengi) e habitava o interior do estado, caracterizando-se como uma história ávida de comprovações sobre este período (CASCUDO, 1984). Destarte, a abordagem da historiografia potiguar, mesmo sendo voltada para o Rio Grande do Norte enquanto espaço onde se desenrolaram os fatos que compõem a história do estado, peca, pois, assume, em geral, como ponto de partida (ou marco cronológico) o século XVI, por se tratar do momento em que se travou "o contato das populações nativas com os colonizadores europeus" (MONTEIRO, 2002: 16).

Apesar da pré-história norte-rio-grandense não haver sido incluída nas sínteses históricas até então produzidas no estado, é possível observar alguns trabalhos onde ela aparece de forma central, ou secundária. Entretanto, são obras que demonstram uma série de informações desencontradas, obsoletas e, às vezes, até pejorativas, contribuindo para uma mitificação da pré-história no Rio Grande do Norte. Nestes casos, o patrimônio arqueológico atua como forma de comprovar o fato de que "os Potiguares e Tabajaras, do ramo Tupi, no litoral, como também os 
Cariris, do ramo Tapuyas (sic), no interior, foram descendentes dos cários (fenícios) de onde todos nós, também, descendemos" (MOURA, 1986: 23 - 24).

Paralelo a esta situação, há também casos em que as informações são relativas mais à pré-história americana do que potiguar propriamente dita e nesse caso, alegasse como justificativa para isto que "o avanço de nosso conhecimento sobre os primitivos habitantes, entretanto, esbarra em uma grande dificuldade: a carência de vestígios dessas culturas" (MONTEIRO, 2002: 20). Entretanto, cumpre esclarecer sobre a suposta 'carência de vestígios dessas culturas', pois, não existe uma carência e sim uma redução das "possibilidades de interpretação do arqueólogo" (GOMES, 2002: 16) frente à quantidade de elementos da cultura material encontrados em solo norte-rio-grandense, dos quais a coleção arqueológica do MHLE é um exemplo, que dificilmente podem ser associados a um tronco lingüístico ou a uma etnia específica. Isto, de fato, só põe em relevo as deficiências apresentadas pela historiografia potiguar no que concerne a temáticas relacionadas aos grupos indígenas de antes e de depois do contato com os europeus.

\section{Assim, o que se pode então apreender desta cultura material?}

Sujeito canhestro, mercador de pau-brasil, personagem que se absteve de praticamente todo o processo de construção do Brasil. Indivíduo de vida rude, hoje semelhante aos 'caboclos sertanejos' que herdaram a valentia, mas não a preguiça do indígena; bárbaro e detentor de uma cultura efêmera, desprovida de monumentalidade. Tais foram os estereótipos formulados a respeito das sociedades indígenas, os quais, creio que já foram demonstrados pelo estudo sobre as sínteses históricas do Rio Grande do Norte, principalmente, enquanto parte de uma concepção ideológica que se fez ao nível brasileiro.

"A historiografia brasileira tradicional, pautada na concepção positivista, que privilegiou a ação dos 'heróis nacionais', em detrimento de outros sujeitos históricos, teve respaldo na política de preservação em nosso país. Elegemos, no decorrer da história os bens culturais representativos dos segmentos dominantes, sobretudo os ligados ao elemento de origem européia, e relegamos ao 
esquecimento a contribuição de outros segmentos étnicos na formação da cultura brasileira" (SANTOS Apud ORIÁ, 2002: 135).

Trata-se assim, de produções historiográficas que deram margem a concepções 'museológicas' no Lauro da Escóssia, de tal forma que neste também pode ser observada uma certa valoração do tipo: "A espada que D. Pedro I utilizou quando proclamou a Independência", ou "O bacamarte de Domingos Jorge Velho". A diferença, é que no caso do MHLE a mitificação ocorre em relação à resistência ao cangaço, ou ao primeiro voto feminino e/ou à libertação dos escravos. Neste sentido, tornam-se mais comuns frases como "Esta é a arma de onde saiu o tiro que matou Jararaca", ou, "Foi com esta caneta que Celina Guimarães assinou o nome antes de ser a primeira mulher a votar na América Latina".

No caso dos artefatos arqueológicos, por serem também objetos associados aos pretéritos grupos indígenas do $\mathrm{RN}$, tem-se uma espécie de mitificação que não foi dotada da mesma exuberância com que foi tratado em outras paragens, por exemplo, o elemento Bandeirante, que pode ser caracterizado como uma mitologia "imposta como uma ideologia de massa graças à manipulação da cultura material" (FUNARI, 1995: 43).

A mitificação indígena na narrativa histórica foi preconceituosa na medida em que descaracterizou os elementos culturais de etnias que passaram a ser tratadas tal qual em alguns museus tradicionais, onde de certa forma ainda o são, ou seja, tidos "como exóticos, fósseis vivos da espécie humana" (BRUNO, 1999: 3).

A presença indígena posta a partir desta perspectiva não faculta a reflexão, torna-se, no caso museográfico, a exposição pura e simples de objetos e contribui para o esquecimento de uma memória já bastante fragilizada. Até mesmo o ideal de formação étnica nacional tendo por base a junção de 'três raças' não pode ser representado em uma historiografia que evidencia uma continuidade históricocultural apenas para o branco colonizador, enquanto o indígena aparece e desaparece isoladamente.

No plano museográfico esta ação vê-se reproduzida em exposições que, por exemplo, não mostram elementos da cultura material européia agregados ao uso indígena, ou até mesmo os espólios que demonstrassem o contato interétnico. 
Neste tipo de exposição, por diversas vezes, o indígena continua sendo aquele que vivia sob uma cultura inferior e era incapacitado de fazer uso de objetos 'civilizados'.

Caso tais assertivas não representem de fato o que se pensa quando uma exposição é elaborada, ao menos é o que se pode apreender destes quando expostos e/ou mal acondicionados, ou de uma historiografia que reforça esta idéia. Ainda no que diz respeito ao museu, vê-se que ele, em alguns casos, "suprime o tempo e a presença de agentes da História" (FUNARI, 1995: 37). Tratando-se a coleção arqueológica do Museu Histórico Lauro da Escóssia a partir de um ponto de vista apenas historiográfico, não se observa uma concepção que reconheça a heterogeneidade das etnias no sentido de perceber a diferença como algo que não seja tão somente a inferioridade.

Pensando-se assim, até mesmo a concepção de um 'objeto portador de passado' torna-se inviabilizada, já que aos olhos de um observador comum, o bacamarte de Domingos Jorge Velho representa muito mais do que a flecha utilizada por um caçador indígena quando no abate de sua presa.

No caso de uma coleção arqueológica formada através da entrega de materiais, o elemento de ligação destes objetos com as sociedades que os executaram está mais próximo do relato de como estes foram apreendidos por observadores alheios à cultura que os produziu, neste caso os cronistas ou os etnógrafos, do que da produção historiográfica cientificamente constituída.

A concepção de uma coleção arqueológica inserida em uma temática sobre 'A terra e o homem do Oeste potiguar', como a que se pretende implantar no MHLE, não pode deixar de pensar os objetos desta coleção enquanto produtos de sociedades humanas que não aparecem e desaparecem em 'lampejos históricos', conforme dito outrora quando se analisava as obras sobre a história do Rio Grande do Norte, mas sim como grupos que já estavam aqui, que continuaram existindo e que, como sempre haviam aprendido a fazer, se adaptaram ao meio.

O cerne desta discussão parece ser uma concepção contrária à manutenção ideológica, tão presente nos discursos históricos e por sua vez vicejado no trato com a coleção arqueológica do Museu Histórico Lauro da Escóssia. Ao estudarmos esta instituição, observamos que há basicamente duas categorias de 
objetos que percorrem, às vezes, caminhos inconciliáveis e que seriam os objetos/artefatos de natureza histórica e os artefatos/objetos de natureza arqueológica. Isto posto, cumpre pensar uma instituição que se "vincularia" a dois tipos de pesquisadores, historiadores e arqueólogos, assim sendo, a vacância (lacuna) deixada por um seria ocupada pelo outro, o que explicaria, ou ajudaria a explicar a maior relação com o referencial (ou referências) historiográfico (as) no que cumpre ao trato com as coleções no Museu Lauro da Escóssia. Isto posto, ao menos na teoria, o quadro em um museu universitário deveria ser diferente, será? É necessário então acompanharmos a situação no Museu Câmara Cascudo. 


\section{CAPÍTULO III}

Arqueografia dos estudos em pré-história e arqueologia no Museu Câmara Cascudo e a transposição expográfica destes estudos. 
Pesquisar sobre a Arqueologia no Museu Câmara Cascudo é de certa forma, decapar os estratos mais antigos da arqueologia de origem científicouniversitária no estado. Isto porque o atual MCC, formado por vários departamentos, é o produto contemporâneo de um antigo instituto de pesquisas da outrora Universidade do Rio Grande do Norte (federalizada em 1962), tendo sido criado na cidade do Natal no mês de dezembro do ano de 1961. Fruto da iniciativa de quatro professores dessa instituição, o IA (Instituto de Antropologia) tem entre seus fundadores o historiador e folclorista Câmara Cascudo ${ }^{20}$ - talvez o pesquisador norte-rio-grandense mais conhecido fora das terras potiguares. Os primeiros departamentos criados no Instituto de Antropologia foram os de Antropologia Física, Etnografia Geral - com uma seção de Folclore -, e o Departamento de Genética. Entre os temas pesquisados por estes a partir do ano de 1962, merece destaque no departamento de antropologia física, chefiado pelo geólogo José Nunes Cabral de Carvalho, um estudo acerca de sambaquis no Rio Grande do Norte (ATA, 1961: 2).

"A partir daí reuniu importante material etnográfico e arqueológico, organizou cursos visando a formação de especialistas junto à pesquisa de campo e laboratório. Constituindo-se desta forma num forte baluarte da ciência, passou a atuar em diversas áreas do conhecimento, tendo como objetivo precípuo o ensino, a pesquisa e a extensão" (COSTA, 1991: 87).

O instituto de Antropologia, hoje Museu Câmara Cascudo, foi criado para ser um espaço, sobretudo de pesquisa, porém desde os primeiros trabalhos em áreas como a Geologia e a Arqueologia já ficava nítido a formação de acervos que foram inclusive ampliados "através de doações, compra e permuta com outras instituições de pesquisa" (COSTA, 1991: 88), como é o caso, por exemplo de peças de cerâmica marajoaras doadas pelo professor Napoleão Figueiredo, da Universidade do Pará, no ano de 1965 (ATA, março de 1965).

\footnotetext{
${ }^{20} \mathrm{Na}$ 'Ata da 39a Reunião Extraordinária da Congregação de Professores do Instituto de Antropologia da Universidade Federal do Rio Grande do Norte', realizada em 05/10/1973, é dado ciência ao quadro docente da instituição "ter o Magnífico Reitor, conseguido junto às autoridades do MEC, a mudança do no Instituto de Antropologia para Museu (de Antropologia) Câmara Cascudo, medida essa que colocava o I. A. nas mesmas condições do Museu Goeldi e do Museu Nacional do Rio de Janeiro, acrescentando o Diretor ser essa medida de incalculável valor e importância, uma vez que o mesmo poderá abrigar, de agora em diante, todos os campos da pesquisa".
} 
A ampliação das pesquisas e o crescimento dos acervos levaram inclusive à construção de uma sede própria (e permanente), "inaugurada em 21 de março de 1965" (COSTA, 1991: 88). Por conseqüência, em uma espécie de extroversão dos dados advindos das pesquisas a partir de perspectivas educativas e tendo em vista atender ao caráter de extensão deste órgão, enquanto uma entidade da Universidade Federal do Rio Grande do Norte, passaram a ocorrer visitas um fato que levou, inclusive a congregação de professores do Câmara Cascudo a decidir em assembléia por uma cobrança de taxa para as visitas (ATA, julho de 1970).

Outra característica forte deste museu, ao menos em suas primeiras três de décadas de atuação, foi a formação de profissionais em áreas como a Antropologia e a Arqueologia, inclusive com pouco mais de um ano que havia sido criado o instituto

\footnotetext{
"teve início o $1^{\circ}$ curso de pesquisador em Antropologia que contou com a participação de notórios docentes como José Nunes Cabral de Carvalho (Antropologia Física), Veríssimo de Melo (Antropologia Cultural), Protásio de Melo (lingüística) e Antônio Campos e Silva (geologia do quaternário e paleontologia) e os professores visitantes Egon Schaden (índios do Brasil), Napoleão Figueiredo (arqueologia e etnologia do Brasil) e Estevão Pinto (índios do Nordeste), além de outros professores" (COSTA, 1991: 88).
}

O diálogo intenso de pesquisadores desta instituição com os de outras entidades é também algo marcante, relações com instituições congêneres como no caso do Museu Paraense Emílio Goeldi ou entidades de pesquisa como no caso da Academia de Ciências da Philadelphia (Estados Unidos) foram sempre uma tônica no MCC - isto para não mencionar os constantes estagiários empregados em seus departamentos. Contudo esta característica, apesar de ser também muito forte, se esmaeceu com o tempo e podemos dizer que a partir de meados dos anos 1990 este diálogo não é mais tão intenso.

Algo parecido ocorreu no âmbito do Departamento de Arqueologia desta instituição, as pesquisas iniciais, vinculadas ao departamento de antropologia, ganharam um departamento próprio (com duas divisões: uma para líticos e outra para cerâmicas) em junho de 1970. Os trabalhos que vinham em crescimento desde 
meados dos anos 1960 assim continuaram até pelo menos o final dos anos 1980, época em que, aliás, as dificuldades de relacionamento entre os pesquisadores deste departamento já demonstravam estar bastante enrijecidas, conforme pode ser percebido em declarações como essas do professor Gaston Laroche em ofícios encaminhados ao diretor do museu (Prof. Veríssimo Pinheiro de Melo), respectivamente, em 2 e 5 de outubro de 1984:

"Na impossibilidade de chegar a um entendimento cordial com o Prof.
Dr. Vicente Giancotte Tassone, com referência a transferência do
acervo arqueológico deste Departamento (documentação,
equipamentos e locais), entrego a V. Sa. a solução deste problema
para as providências legais cabíveis que melhor lhe convier.

Com referência à carta do Prof. Dr. Vicente Giancotte Tassone de 04/10/1984, cumpre-se especificar os seguintes dados: (...)

Falta o recebimento do arquivo do setor, com toda a documentação sobre as pesquisas, cursos, movimento dos estagiários, cooperações com instituições, relatórios diversos, mapas, desenhos, fotografias de trabalhos de campo e laboratório, slides e correspondência em geral. [...] Também não temos nenhuma relação oficial das coleções de material arqueológico".

Seja como for, é provável que essa diminuição no ritmo das atividades científicas no MCC se deva ao fato de que não houve nenhuma reformulação no quadro de pesquisadores do museu, seu quadro é praticamente o mesmo desde a década de 1980 e, muito pelo contrário, ao invés da contratação houveram sim muitas baixas. Departamentos como o de arqueologia, por exemplo, que chegou a contar em 1986 com seis professores hoje possui apenas um, já outros departamentos, como o de antropologia e o de genética, foram desativados. Não bastasse isto, a que se considerar também possibilidades como a de que os profissionais que hoje integram os departamentos de Estudos Ambientais, Botânica, Arqueologia, Paleontologia e Museologia tenham por razões de pesquisa, institucionais, ou pessoais mesmo, se encapsulado no Câmara Cascudo. Entretanto, apesar disto nos foi possível observar vários aspectos pertinentes à história do MCC e de uma maneira mais especifica, a arqueologia e musealização desta neste museu. 


\section{De 1965 aos anos 2000: as pesquisas acadêmicas e os trabalhos de arqueologia por contrato no âmbito do Museu Câmara Cascudo.}

De início tênue, os trabalhos na área de arqueologia desenvolvidos pelo IA são incrementados a partir de 1965 com o ingresso deste nas atividades do Programa Nacional de Pesquisas Arqueológicas - PRONAPA. Isto ocorreu, porque em 05 de maio de 1965 a Congregação de Professores do Instituto de Antropologia votou sobre uma proposta de intercâmbio advinda do 'Smithsonian Institution', Washington/EUA, formalizada pela pessoa de Cliford Evans, do Departamento de Arqueologia daquela instituição. O convênio poderia ser prorrogado por cinco anos e

"nêste compromisso o Smithsonian forneceria um veículo, tipo rural, e 1.000 cruzeiros anuais para sua manutenção. O I.A. entraria no acordo com o concurso do arqueólogo Nássaro Antonio de Souza Nasser, e sua equipe, que iria trabalhar em ligação direta com o Smithsonian, o CNPQ, e o Patrimônio Histórico e Artístico Nacional" (ATA, 1965: $10-11$ ).

Destarte, vemos que a intensificação das pesquisas arqueológicas no Rio Grande do Norte está diretamente relacionada a este convênio com a instituição dos EUA. O convênio Instituto de Antropologia - 'Smithsonian Institution' representa o segmento norte-rio-grandense do PRONAPA.

No segundo semestre de 1965 o arqueólogo potiguar Nássaro Nasser iniciou seus trabalhos como um dos pesquisadores que faziam parte deste programa de pesquisas e, como tal, publicou seus resultados num periódico intitulado 'Publicações Avulsas do Museu Goeldi'. Os dados veiculados nestas publicações constituem a primeira ordem de estudos arqueológicos feita, em um espaço acadêmico-universitário, no Rio Grande do Norte.

Dos idos de 1965 a 1970 o professor Nasser pesquisou entorno de 20 sítios arqueológicos, sendo que quatro destes foram sítios cemitérios e os outros sítios habitação. O material foi coletado, inclusive como previa parte da metodologia usada no PRONAPA, em sua maioria na superfície e em alguns casos em escavações que não excederam os $50 \mathrm{~cm}$ de profundidade. Os artefatos coletados 
são de diversos tipos, líticos, malacológicos, óssos, contudo, a grande maioria é composta por cerâmicas.

As cerâmicas coletadas por Nasser e sua equipe, teoricamente, compõem dois grupos distintos e a variação entre estes fez com que o professor Nássaro estabelecesse tipos de cerâmicas que atendem as fases Curimataú e Papeba. As inferências acerca dos grupos humanos ocupantes destes assentamentos versam sobre as atividades de grupos horticultores ceramistas, sem que, contudo, ocorra um maior aprofundamento no estudo relacionado à presença de caçadores-coletores em tais sítios.

A 'Fase Curimataú' foi caracterizada a partir dos trabalhos da equipe do Instituto de Antropologia na foz do sistema Curimataú-Cunhaú. Trata-se de uma área entrecortada por morfoclimas diferentes, dado que se estende do litoral ao sertão norte-rio-grandense, e da mesma forma apresenta várias diferenças no que tange ao relevo, tipos de solo e vegetação. O material foi coletado em 18 sítios e a profundidade não ultrapassou os $15 \mathrm{~cm}$.

"A cerâmica constitui o traço mais característico desta fase, revelando-se predominantemente o tipo sem decoração - dos cacos coletados, em média, $82 \%$ correspondem aos tipos simples, 13,5\% aos decorados pintados e 4,5 são decorados plasticamente.A classificação da cerâmica simples através do tempêro evidenciou três tipos: Pirari Simples, temperado com cacos triturados, bolas de argila e grãos de quartzo angulosos e subangulosos; Cunhaú Simples, com tempêro argilo arenoso, compacto, grãos de quartzo leitoso, angulosos e subangulosos que chegam a atingir $3 \mathrm{~mm}$ e, em menor freqüência, feldspato e hematita; Pequeri Simples, com tempêro predominantemente arenoso, grande quantidade de grãos de quartzo angulosos e subangulosos, além de feldspato. O método de manufatura mais usual em todos os tipos é o acordelado, embora em pequena escala verifique-se o modelado. A queima apresenta oxidação incompleta.[...] $O$ tratamento de superfície, tanto externa quanto internamente, é irregular, sendo comum as marcas deixadas pelo instrumento alisador.[...]A técnica decorativa diagnóstica é a pintura em vermelho e prêto sôbre engobo branco, aplicada geralmente recobrindo o interior dos vasilhames, a partir da borda ou face externa do lábio - nos vasos de bôca constrita esta técnica é aplicada externamente. O vermelho sôbre branco, o vermelho em duas tonalidades, o banho vermelho sôbre as superfícies interna e externa, e, mais raramente, o prêto são outras técnicas usadas" (NASSER, 1971: $182-183$ ). 
O sítio arqueológico que caracterizou a 'Fase Papeba' foi trabalhado em fins da década de 1960 e fica no município de Senador Georgino Avelino, litoral sul do Rio Grande do Norte. A geomorfologia da área apresenta platôs do terciário, os chamados tabuleiros, alguns dos quais atingem 40 metros de altura. A vegetação varia entre arbustiva - tipo savana, com espécies como a 'Hancornia speciosa' (mangabeira), resquícios de Mata Atlântica e manguezais. O clima é o tropical úmido, com temperaturas entre $24^{\circ}$ e $28^{\circ}$ e uma média pluviométrica de $1000 \mathrm{~mm}$ anuais.

O 'sítio guia' da fase Papeba possui $18400 \mathrm{~m}^{2}$, apresenta formato elíptico e as concentrações de materiais estavam em manchas de terra escura. Os materiais provem não só de coletas de superfície, mas também de escavações por níveis artificiais - que chegaram a atingir $40 \mathrm{~cm}$ de profundidade. O sítio também apresenta artefatos cerâmicos da Fase Curimataú, embora de forma bastante reduzida e num nível aparentemente mais recente que os materiais Papeba. Foram coletados 12.700 fragmentos, classificados a partir de sua decoração como sendo de dois tipos: o simples e o decorado, ambos com as superfícies alisadas.

"O Papeba Simples caracteriza-se pelo tempero de areia grossa, com grãos de quartzo que variam de $1,0 \mathrm{~mm}$ a $0,5 \mathrm{~mm}$. O feldspato aparece eventualmente. Guaraíras Simples destaca-se pelo tempero de areia fina, com grãos de quartzo inferiores a $0,5 \mathrm{~mm}$. O tempero nos dois tipos está bem distribuído. O método de manufatura mais freqüente é o acordelado embora apareçam exemplares modelados. $\mathrm{Na}$ queima predomina a oxidação incompleta. [...] O tipo considerado decorado - Papeba Vermelho - apresenta-se apenas com um banho vermelho externo, interno ou em ambas as superfícies. Nele destacam-se os apêndices verticalmente vasados, provavelmente com a função de passagem para um cordel de sustentação dos vasilhames. [...] As formas básicas estabelecidas são quatro, todas de volume reduzido: forma 1 - boca circular constrita, lábio apontado, borda direta e introvertida, bojo ovóide e base arredondada; forma 2 - boca circular, abertura ampliada, lábio apontado, borda com inclinação externa, bojo em meia calota, base arredondada, caracterizando tigelas e predomina no Papeba Vermelho; forma 3 boca circular, abertura ampliada, lábio apontado, borda com inclinação externa, bojo esférico e base arredondada, comum no Papeba Simples; forma 4 - boca circular ampliada, lábio redondo, borda extrovertida, bojo em meia-esfera e base plana. Esta última forma associa-se aos vasilhames de maior volume" (NASSER, 1974: $158-159)$. 
Uma vez caracterizadas as fases, o professor Nasser procedeu a uma série de estudos, na tentativa de posicioná-las no âmbito das fases e tradições estabelecidas até aquele momento pelos pesquisadores do PRONAPA. No que tange aos aspectos de manufatura e estilísticos, a fase Curimataú foi associada à Tradição Tupiguarani (ou Tupinambá), já a fase Papeba não foi caracterizada como vinculada a nenhuma tradição específica, sendo mais um tipo de cerâmica de fabricação regional.

No que concerne a cronologia, cabe ressaltar que não foram feitas datações absolutas e talvez por isso tenha sido mais fácil posicionar a fase Curimataú, já que esta seria filiada a Tradição Tupiguarani, do que a Papeba. A primeira possui como datação relativa o ano de 1300 e a segunda, tendo em vista o fato de que aparecia em níveis mais abaixo do que as cerâmicas Curimataú, foi caracterizada como sendo mais antiga.

As pesquisas feitas na bacia do rio Curimataú e no município de Senador Georgino Avelino trouxeram importantes contribuições aos estudos relativos à préhistória do Rio Grande do Norte. Porém, ainda na década de 1970 elas foram interrompidas e com o fim do trabalho nestes lugares, ficaram a descoberto uma série de questionamentos com relação, principalmente aos materiais cerâmicos das fases Curimataú e Papeba.

Ainda nos anos 1960 outras atividades ligadas de maneira indireta ao setor de arqueologia do MCC foram desenvolvidas, tratam-se dos primeiros trabalhos feitos em sítios arqueológico-paleontológicos conhecidos como tanques ${ }^{21}$.

\footnotetext{
21 "Os tanques naturais são estruturas geológicas comuns no Quaternário continental da região Nordeste do Brasil. Estas estruturas são produzidas pelo aprofundamento das fraturas existentes ao longo da superfície de rochas do embasamento, através de processos físico-químicos de intemperismo (OLIVEIRA e HACKSPACHER, 1989; MABESOONE et al., 1990). O preenchimento sedimentar destas depressões se encontra geralmente compartimentado em duas ou três camadas (SANTOS et al., 2002) e resulta da desagregação mecânica e química das rochas encaixantes e do transporte de material clástico alóctone por enxurradas (OLIVEIRA e HACKSPACHER, 1989). As assinaturas tafonômicas presentes no material paleontológico coletado nestes depósitos sugerem transporte pouco expressivo dos fósseis, havendo evidências da atuação de processos pósdeposicionais, como compactação das camadas e revolvimento, que contribuem para a fragmentação do material (OLIVEIRA \& HACKSPACHER, 1989; BERGQVIST et al., 1997). Atualmente, os tanques são de grande importância para a fauna e para as populações humanas do interior semi-árido do nordeste brasileiro por se constituírem reservatórios naturais de água durante os períodos de estiagem, o que implica no fato de que em vários casos os sedimentos, por conseqüência o material paleontológico e arqueológico, dos tanques são retirados para a elaboração de "cisternas naturais"” (SANTOS JÚNIOR, PORPINO \& SILVA, 2007: 1-2).
} 
Os trabalhos nestes tipos de sítios foram coordenados por pesquisadores ligados a equipe de Paleontologia do Departamento de Geologia do Museu Câmara Cascudo, não houve a presença de arqueólogos nestas pesquisas, contudo, o material arqueológico coletado passou a integrar o acervo do MCC.

Este material é conhecido a partir de CARVALHO et al. (1966) como sendo composto de vestígios líticos e cerâmicos, havendo casos inclusive, em que em uma mesma camada (que ia de $65 \mathrm{~cm}$ a 1,10 $\mathrm{m}$ ) onde apareceram estes tipos de vestígios também foram coletados fósseis. Os artefatos líticos são mencionados como sendo trituradores e machados e embora seja feita referência a ocorrência de sílex nas camadas onde os líticos foram encontrados, em nenhum dos casos o tipo de suporte usado na elaboração dos artefatos foi explicitado assim como a forma destes.

A cerâmica encontrada ocorreu nos mesmos níveis que os líticos e, diferentemente destes últimos, se mostrou bastante variada: um tipo que se apresentava de forma espessa e grosseiramente elaborada, com grãos de quartzo na massa e sem vestígios de ornamentação; um outro tipo era pouco espessa, razoavelmente trabalhada, sem grãos de quartzo na massa e um último tipo apresentava formas grosseiras, com grãos de quartzo e decoração escovada. Foram coletados também três discos de cerâmica perfurados no centro (pesos?), com diâmetro médio de $4 \mathrm{~cm}$ e espessura da ordem de $1 \mathrm{~cm}$.

Destarte, os tanques naturais se revelam pródigos em possibilidades de entendimento de aspectos relativos a vida do homem pré-histórico na região central do Rio Grande do Norte, seja pelo vital entendimento do ambiente e dos processos formadores deste tipo de sítio arqueológico/paleontológico, ou seja, devido a ocorrência de vestígios culturais dos pretéritos grupos humanos nesta porção do estado e que se constituem como herança, ou patrimônio, do povo potiguar. Apesar disto, novas pesquisas nesses sítios que envolvessem a participação do Departamento de Arqueologia não ocorreram nas décadas seguintes.

A produção acadêmica na área de arqueologia do Museu Câmara Cascudo diminuiu ao longo dos anos 1970 e só veio a retomar o seu ritmo quase no final desta mesma década, por volta de 1978 quando "o casal Laroche foi convidado, 
pelo então Diretor do Museu 'Câmara Cascudo' da U.F.R.N., Dr. José Nunes Cabral de Carvalho, para recuperar o Setor de Arqueologia deste Museu" (LAROCHE, 1980). Ainda no final da década de setenta do século XX outros três arqueólogos, os professores Vicente Giancontti Tassone, Iramar Soares de Araújo e Tom Miller Jr., passaram a desenvolver atividades de pesquisa junto a este setor, contudo, este último não era vinculado ao MCC e sim a ECLHA da Universidade Federal do Rio Grande do Norte e cumpria parte de sua carga horária no museu.

Assim, com estes professores e mais o 'casal laroche' (Armand François Gaston Laroche e sua esposa Adjelma Soares Laroche), o Departamento de Arqueologia do MCC entrou em uma nova fase, onde o aumento da equipe de pesquisadores contribuiu sobremaneira para uma reestruturação no espectro das investigações até então desenvolvidas, propiciando, inclusive, a participação do Departamento de Arqueologia deste museu em projetos de salvamento arqueológico e, também, nos primeiros trabalhos em sítios arqueológicos do tipo 'abrigo sob a rocha' feitos no estado. A ampliação das pesquisas ocorreu de tal maneira que em 1980 a equipe do museu constatava, por exemplo, que

"numa análise preliminar, com base nas publicações efetuadas e nas indicações dos autores, $75 \%$ do material lítico conhecido no Nordeste procede do Rio Grande do Norte, fundamentalmente dos 45 sítios escavados ou sondados pelo Museu Câmara Cascudo" (TASSONE \& MILLER JR, 1980: 15).

Do final dos anos 1970 e ao longo de toda a década de 1980, além dos trabalhos feitos na região do Baixo Açu (nos anos de 1979, 1980 e 1981), por ocasião do salvamento dos sítios arqueológicos que seriam impactados com a construção da barragem Engenheiro Armando Ribeiro Gonçalves, houveram pesquisas em sítios arqueológicos nas regiões litoral, agreste, central e oeste do Rio Grande do Norte.

$\mathrm{Na}$ região do Açu alguns dos sítios identificados tiveram materiais arqueológicos coletados, como no caso do Sítio Bonito em Jucurutu/RN (figura 15), mas infelizmente nenhuma datação para a área foi adquirida por causa da contaminação das amostras, isto no caso de sítios como o 'Mutamba 2'. 


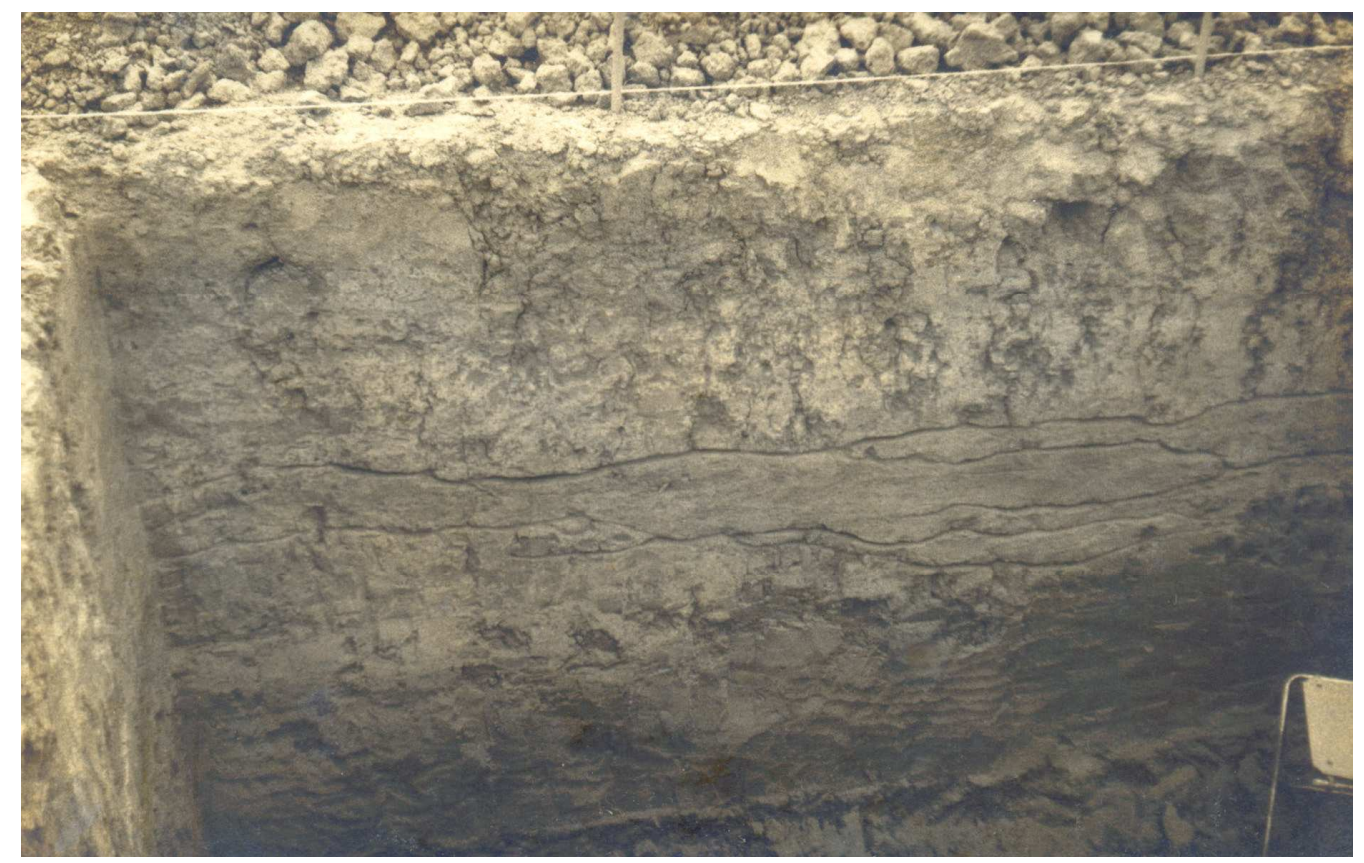

Figura 15. Perfil estratigráfico do Sítio Bonito, em Jucurutu/RN. Este foi um dos sítios escavados por ocasião do Projeto de Salvamento Arqueológico do Baixo Açu (1979 - 1981).

$\mathrm{Na}$ região litorânea foram escavados os sítios Tanques de Baixo e Mangueiros no município de Macaíba/RN. O primeiro, a uma profundidade de $80 \mathrm{~cm}$ e com uma margem de erro de 100 anos, obteve como datação mais antiga 750 anos antes do presente; já o segundo, no mesmo nível de profundidade e com margem de erro de 91 anos, obteve uma datação de 3339 anos antes do presente. Ambos os sítios além de material lítico, apresentaram cerâmicas atribuídas à Fase Papeba - sendo que no caso do Sítio Mangueiros as cerâmicas só foram encontradas até a camada datada de 1796 antes do presente, com margem de erro de 82 anos.

Já em outro município da região litorânea, por volta de 12 anos depois da interrupção dos trabalhos na área da lagoa de Guaraíras, houve uma retomada dos trabalhos na região onde foi descoberto o sítio da Fase Papeba. Desta vez o arqueólogo coordenador dos trabalhos era o professor Dr. Tom Miller Jr., curiosamente, este pesquisador só tomou conhecimento de que a área havia sofrido intervenções arqueológicas anteriores, depois de terminada a primeira campanha de escavação em 1982. Naquela época o Sítio Papeba em escola de campo do Curso 
de Especialização em Arqueologia Pré-Histórica, promovido pelo Museu Câmara Cascudo de 1982 a 1984.

Afora esta campanha de 1982 houve ainda outra no ano de 1983, contudo o material advindo dos trabalhos de campo ficou encostado nas prateleiras até 1987 , quando passou a ser analisado pelo professor Miller no Laboratório de Etnoarqueologia criado quase que nesta mesma época, mas vinculado ao Departamento de Antropologia do Museu Câmara Cascudo e não ao Departamento de Arqueologia, como poderíamos ser levados a pensar.

As análises de Miller para esta área em alguns casos não vão na mesma direção que as de Nasser. Miller afirma que o Sítio Papeba apresenta um padrão de assentamento em forma de ferradura, semelhante ao de aldeias Gê do Centro-Oeste brasileiro, com os detritos localizados na parte de fora da ferradura e uma área central limpa. Ele faz esta afirmação a partir dos resultados de suas prospecções em campo, ocasião em que à hipótese pôde ser testada e quando foi verificado a ocorrência de buracos de poste, de $30 \mathrm{~cm}$ de diâmetro por $40 \mathrm{~cm}$ de profundidade, em cujo interior foram coletados grandes cacos de cerâmica e também um fragmento de concha. Os buracos estavam dispostos de maneira a compor uma habitação e indicando a ocorrência de outras habitações, que dariam então forma a 'ferradura'. Outra constatação feita pelo professor Tom Miller, é a de "que a cerâmica característica do sítio é da tradição Aratu, a qual tem a mesma distribuição geográfica que a das línguas do tronco Macro-Gê" (MILLER JR., 1991: 544). Em entrevista, o professor Miller disse que não identificou a presença de outro tipo de cerâmica.

Miller coletou ainda outras evidências como uma bola de boleadeira, objetos de amazonita (matéria-prima não encontrada no litoral), fragmentos de material malacológico (indicativos da dieta dos povos que lá habitaram), lascas trabalhadas de sílex, rodas de fuso, fragmentos de porcelana e alças de cerâmica. Contudo, "as evidências de contato com os europeus que mais nos deixou perplexos são umas pequenas esculturas (ornamentos?) representando folhas e cabeças de serpentes (em estilo naturalista europeu) mas executados em osso" (MILLER JR., 1991: 544 - grifo do autor). A hipótese do professor Tom Miller é a de que o Sítio 
Papeba tenha sido ocupado por grupos Tapuia que já em tempos históricos travaram contato com os holandeses, por ocasião da ocupação holandesa na Capitania do Rio Grande - época em que as etnias genericamente chamadas de Tapuia lutaram ao lado dos batavos, contra as tropas portuguesas.

Em meados dos anos 1980, na região Central das terras potiguares foram trabalhados sítios arqueológicos nos municípios de Lajes, São Tomé e Caiçara do Rio dos Ventos. Estes municípios foram escolhidos tendo em vista as hipóteses de trabalho adotadas pelo professor Gaston Laroche acerca de um tipo específico de indústria lítica norte-rio-grandense, chamada por ele de Tradição Potiguar ${ }^{22}$ e que possuía como principal elemento identificador pontas de projéteis (figura 16), as quais foram pela primeira vez vistas por Laroche no acervo do Museu Câmara Cascudo e sobre as quais ele afirma ainda: "Vários exemplares de pontas de projéteis pertencentes a esta Tradição, podem ser encontradas em Museus ou com colecionadores deste Estado, porém elas não possuem nenhuma datação" (LAROCHE, 1987: 14).

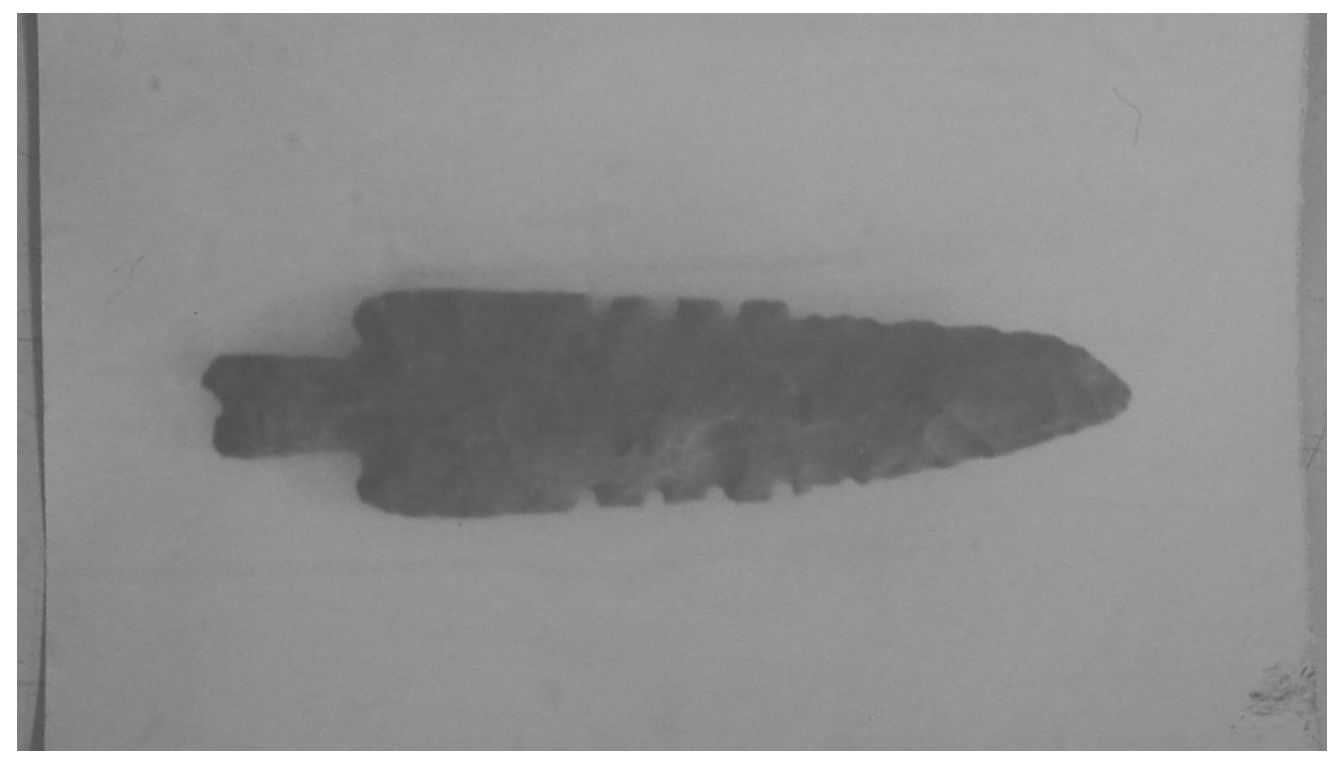

Figura 16. Ponta de projétil que integrava a o acervo do Museu Câmara Cascudo e que hoje pode ser vista apenas em fotografias do arquivo, no Departamento de Arqueologia desta instituição.

\footnotetext{
${ }^{22}$ Segundo LAROCHE (1983: 18): "As tecnologias das tradições Itaparica e Potiguar são idênticas, entretanto os formatos diferem, e falta-nos achados em estratigrafias e datações, no sentido de esclarecer um possível parentesco".
} 
Nestes municípios houve coleta de material em apenas dois sítios arqueológicos, a 'Pedra do Letreiro'(figura 17) e 'Pedra do Balcão', ambos localizados no município de Caiçara do Rio dos Ventos. O total de peças coletadas foi de 369, o sítio que mais apresentou materiais foi a Pedra do Balcão (148) sendo que ele foi escavado até a profundidade de $2 \mathrm{~m}$, quando foram coletadas amostras. Este sítio, segundo Laroche, está entre os mais antigos do Rio Grande do Norte e teria alcançado 10.270 anos antes do presente (LAROCHE, 1988: 42).

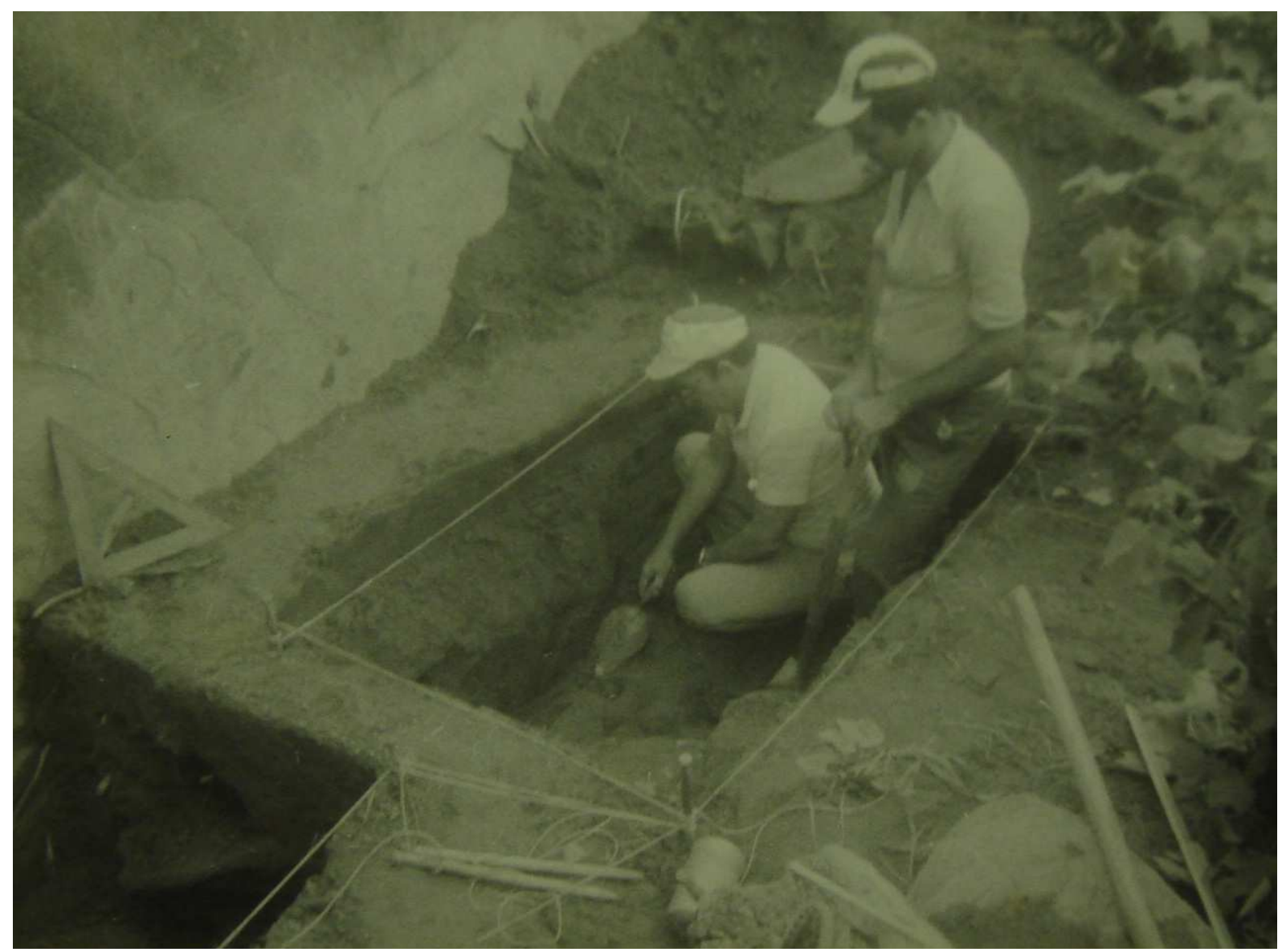

Figura 17. Escavação no sítio arqueológico Pedra do Letreiro, Caiçara do Rio dos Ventos/RN, março/junho de 1985.

Se para o Sítio Pedra do Balcão houve datação, o mesmo não pode ser dito de um outro sítio escavado já no final dos anos 1980 no município de Martins, região Oeste do Rio Grande do Norte, e chamado de 'Casa de Pedra'. As amostras coletadas neste sítio foram enviadas pelo professor Laroche para o seu contato no 
Departamento de Física Nuclear da Universidade Federal do Ceará, a professora Dra. Maria Marlúcia Freitas Santiago, e esta as encaminhou junto com materiais da própria professora para São Paulo. Contudo, parece que houve algum problema pois em uma carta do professor Laroche lê-se o seguinte:

\footnotetext{
"Pelas notícias, creio que as peças que a amiga enviou para São Paulo, estão irremediavelmente extraviadas, conseqüentemente acredito (embora espero estar enganado), que as minhas amostras estão inutilizadas"
}

A julgar por este trecho da correspondência do professor Laroche endereçada no dia 04 de janeiro de 1989 para a professora Marlúcia Santiago, as amostras para datação do Sítio Casa de Pedra foram extraviadas, isto explicaria o fato de não terem sido apresentadas datações para este lugar que segundo Laroche era de uma ocupação bem antiga. O Sítio Casa de Pedra foi escavado em três etapas entre os anos de 1987 e 1989, milhares de peças líticas foram coletadas, contudo uma triagem do material mostrou que boa parte não poderia ser considerado evidência arqueológica. Os trabalho na Casa de Pedra são os últimos de um período de pesquisas mais intensivas, levadas à cabo por pesquisadores do Departamento de Arqueologia do Museu Câmara Cascudo.

Ainda no final dos anos 1980 já se podia observar que as atividades do setor de arqueologia do MCC estavam entrando em declínio, arqueólogos estavam saindo do museu e outros, como o professor Tom Miller que montou um Laboratório de Etnoarqueologia vinculado ao Departamento de Antropologia, estavam buscando outros caminhos de pesquisa. Isto para não mencionar o fato de que muitos dos dados obtidos nas mais de duas décadas de pesquisas intensivas levadas à cabo pelo Departamento de Arqueologia do MCC foram, da mesma forma que as amostras para datação do Sítio Casa de Pedra, extraviados. Uma explicação para isto pode ser atribuída

"sobretudo, às múltiplas crises internas que acabaram dissolvendo a maior parte do corpo técnico e de arqueólogos do Museu Câmara Cascudo e apenas parte da documentação e dos relatórios parciais constituem-se como importantes documentos (...), guardados sob 
os cuidados do atual diretor do Departamento de Arqueologia, professor e arqueólogo Luiz Dutra que conta, também, com parte dos mapas e descrições de importantes projetos (...). Uma fonte importante para a construção de um histórico de pesquisas arqueológicas nesse estado" (ROBRAHN-GONZÁLES, 2005 grifo nosso).

Diminuído em seu quadro, este departamento se manteve em funcionamento nos anos 1990 e início dos anos 2000. Houveram cadastramentos de sítios nos municípios potiguares de Florânia, Caiçara do Rio dos Ventos, Rui Barbosa, Barcelona, São Tomé, Sítio Novo, Lagoa de Velhos, Itaú, Santana do Matos, Pedro Avelino e Cerro Cora. Voltaram a aparecer publicações de pesquisadores ligados ao Departamento de Arqueologia do MCC, que em certa medida retomam trabalhos antigos e acenam com a possibilidade de novos conhecimentos $^{23}$.

Contudo, uma nova fase deste departamento é enxergada apenas a partir do desenvolvimento de trabalhos de arqueologia por contrato. Após mais de vinte anos da primeira experiência, o Departamento de Arqueologia do Museu Câmara Cascudo retomou o caminho dos salvamentos arqueológicos. Estes trabalhos foram feitos em parceria com a empresa Documento Antropologia e Arqueologia, por necessidade do salvamento dos sítios arqueológicos que seriam impactados pelas linhas de transmissão da Usina Termelétrica do Vale do Açu. As atividades de campo se desenrolaram nos anos de 2003 e 2004, abrangendo os municípios de Açu, Ipanguassú, Afonso Bezerra, Alto do Rodrigues, Pendências, Macau, Guamaré, Apodi, Felipe Guerra e Governador Dix-sept Rosado.

Foram identificados ao todo 35 sítios, sendo a soma de 8.649 peças indica que houve coleta em apenas alguns destes. A maior parte do material coletado corresponde a peças líticas, este tipo de artefato corresponde inclusive ao horizonte cultural caçador-coletor identificado no sítio mais antigo dos que foram registrados, o Sítio Areião com datação de 3.380 anos antes do presente. Os dados

\footnotetext{
23 1) SOUZA NETO, Luis Dutra; BERTRAND, Daniel. Mapeamento dos sítios arqueológicos do município de Florânia/RN. MNEME - Revista de Humanidades. Caicó (RN) v. 7, n. 15. abril/maio de 2005. 2) SOUZA NETO, Luis Dutra; BERTRAND, Daniel; SABINO, Ana Amélia de Brito. Análise da coleção lítica do Sítio Arqueológico Serrote dos Caboclos, município de Pedro Avelino/RN. MNEME Revista de Humanidades. Caicó (RN) v. 7, n. 16. junho/julho de 2005.
} 
advindos destes trabalhos arqueológicos somam uma boa contribuição no que diz respeito, principalmente, ao estudo dos grupos humanos que habitaram a região noroeste do Rio Grande do Norte.

Historicizar as fases da pesquisa arqueológica no Museu Câmara Cascudo foi importante no sentido de que, tomados em seu conjunto, os três volumes relativos aos relatórios ${ }^{24}$ dos projetos de prospecção e resgate arqueológico, a produção acadêmica, os cadernos de campo de alguns pesquisadores, as documentações relativas a projetos de pesquisa, as correspondências (recebidas e enviadas), os ofícios (recebidos e encaminhados), as matérias de jornais, as portarias e outros tipos de documentação interna do museu, atuaram de maneira a contribuir para a formação de um panorama geral no que concerne a quantidade e a espacialidade na origem (figura 18) dos artefatos que compõem o acervo de arqueologia do MCC.

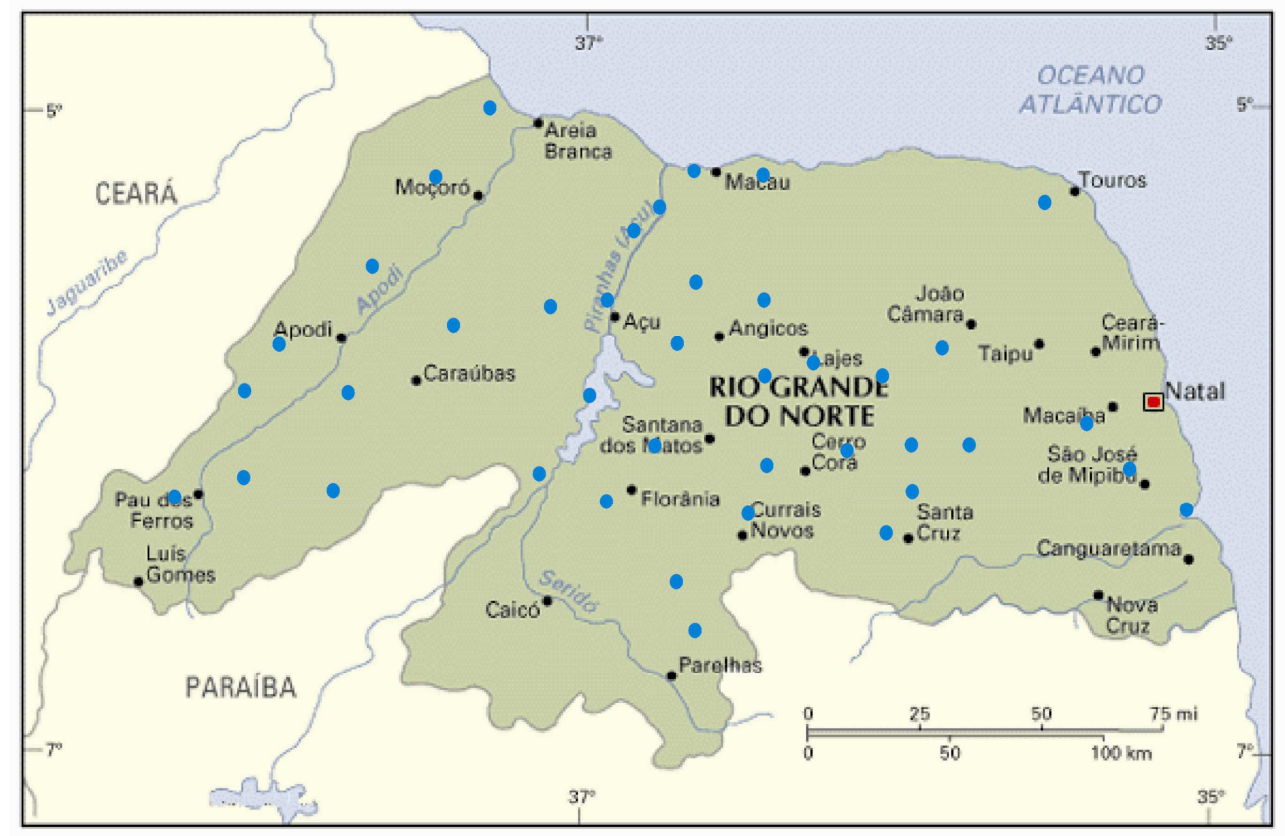

Figura 18. Mapa do Rio Grande do Norte, onde em azul são os lugares onde Departamento de Arqueologia do MCC desenvolveu trabalhos.

24 1) ROBRAHN-GONZÁLES, Érika M. et. al. Programa de Prospecção e Resgate do Patrimônio Arqueológico: Linha de Distribuição 138 KV - Assú/Guamaré, Rio Grande do Norte. Relatório Final. Documento: Antropologia e Arqueologia, Apoio Institucional: Museu Câmara Cascudo. Junho/2004; 2) ROBRAHN-GONZÁLES, Érika M. et. al. Linha de Distribuição 69 KV - Governador Dix-Sept Rosado/Riacho da Forquilha, Rio Grande do Norte. Relatório Final. Documento: Antropologia e Arqueologia, Apoio Institucional: Museu Câmara Cascudo. Julho/2004; 3) ROBRAHN-GONZÁLES, Érika M. et. al. Programa de Prospecção e Resgate Arqueológico LD Assú/Guamaré, Circuito 2, Rio Grande do Norte. Relatório Final. Documento: Antropologia e Arqueologia, Apoio Institucional: Museu Câmara Cascudo. Julho/2005 
Após ter sido traçado um quadro geral das atividades de pesquisa que foram responsáveis pela formação da quase totalidade do acervo de arqueologia do Museu Câmara Cascudo, cumpre-nos então agora observar outros aspectos relativos à estes bens, como o seu gerenciamento e o espaço destes no âmbito da expografia desenvolvida nesta instituição.

\section{O gerenciamento da informação a partir dos Livros de Tombo.}

O livro tombo nos dá uma noção do desenvolvimento de pesquisas e do ingresso de artefatos em uma instituição, é, pois uma ótima fonte de informações no que concerne ao entendimento sobre como esta ocorrendo o gerenciamento dos acervos. No Departamento de Arqueologia do Museu Câmara Cascudo me foram disponibilizados dois livros de tombo e um deles, o mais antigo, foi aberto em outubro de 1963 pelo arqueólogo Nássaro Nasser, já o outro foi uma 'atualização' das informações constantes no primeiro e, apesar de não apresentar data de abertura, tudo leva a crer que passou a receber dados relativos às pesquisas desempenhadas a partir do final dos anos 1990 (figuras 19 e 20).

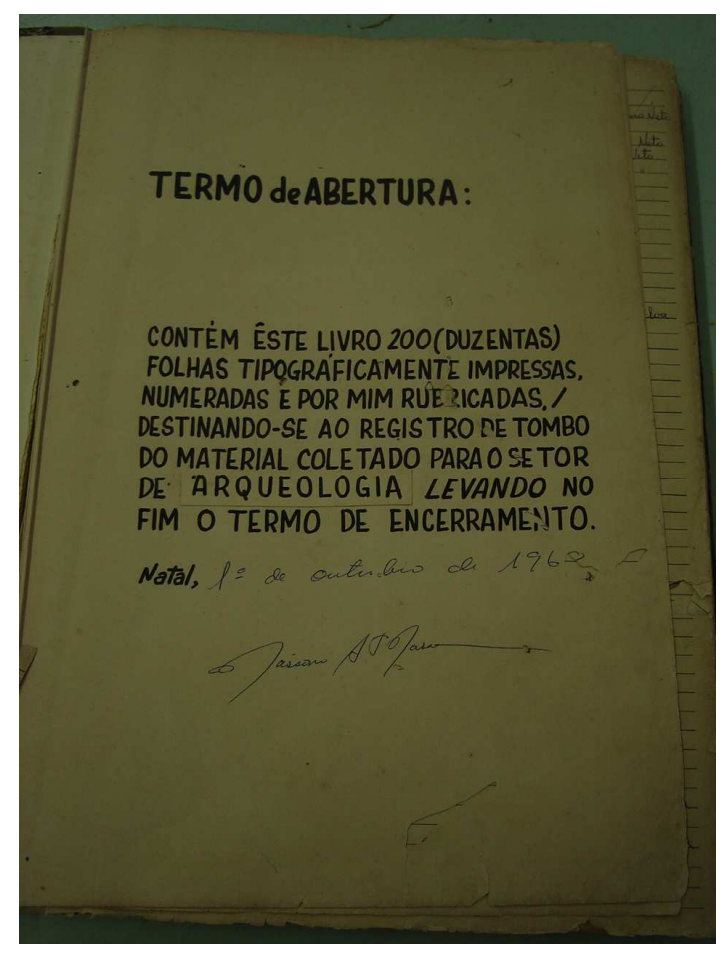

Figura 19. Termo de abertura do primeiro Livro de Tombo do Dept. de Arqueologia do MCC.

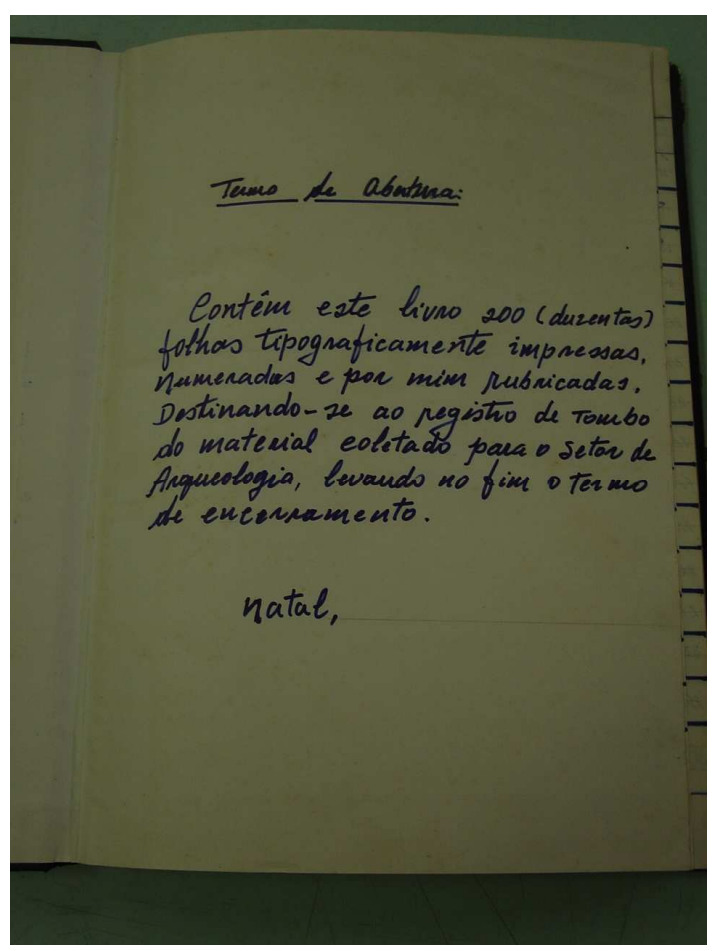

Figura 20. Termo de abertura do segundo Livro de Tombo do Dept. de Arqueologia do MCC. 
A primeira entrada de um artefato arqueológico consta como tendo sido em agosto de 1963, um artefato lítico polido proveniente do município de Afonso Bezerra - de uma localidade conhecida como 'tanque das flores'; já o último registro anotado no primeiro livro ocorreu em 5 de março de 1983, um artefato não especificado que foi retirado de uma escavação no município de Senador Georgino Avelino, nas imediações da Lagoa de Guaraíras, os trabalhos de campo faziam parte de um curso de especialização em Arqueologia Pré-Histórica, "com duração de 720 horas, realizado pelo Museu em 1982-1984 e financiado pelo [sic] CAPES" (SOUZA NETO, 1998).

Há nesses livros um intervalo nas anotações sobre a aquisição de peças, talvez devido à inconstância e divergências teóricas, e também pessoais, entre os pesquisadores do setor de arqueologia do MCC. A numeração segue de 01 a 115 e depois disso é retomada com os materiais provenientes de um sítio arqueológico conhecido como 'Riacho da Volta', em uma fazenda chamada Bom sucesso no município de Angicos/RN, contudo neste ponto em que ela é retomada deixa de ocorrer uma denominação por número e sim por 'saco', saco 01, saco 02 e assim sucessivamente - entre parêntesis aparece a quantidade de peças em cada saco, contudo não há mais uma referência individual das peças (figura 21).

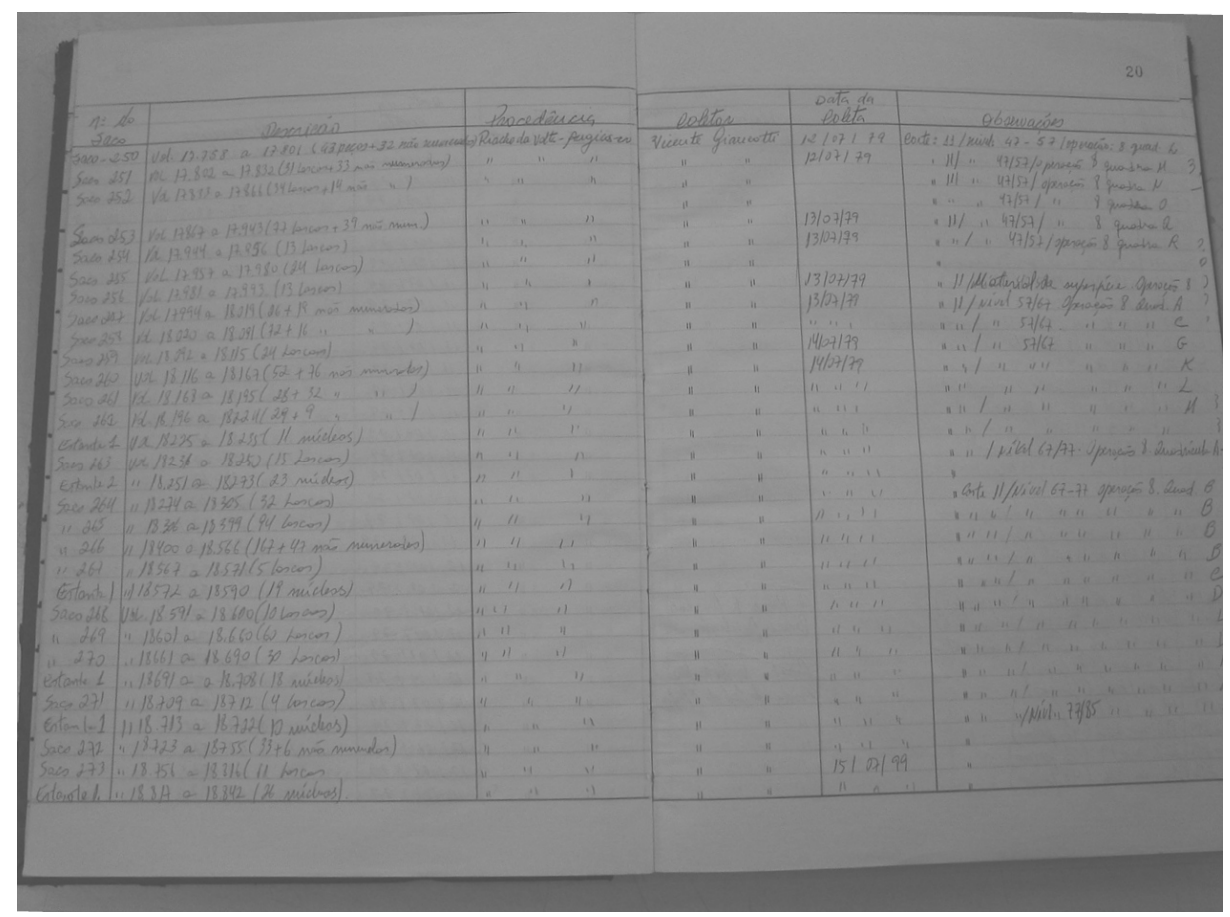

Figura 21. Página 20 do $2^{0}$ Livro de Tombo, à esquerda figura uma numeração por 'sacos'. 
Do ponto entre a peça 115 e o 'saco 01' há um espaço em branco de duas páginas, a última data assinalada foi em 1970 e quando foi retomada, duas páginas depois, já se estava em 02 de março de 1979. Donde surge a dúvida, será que em uma instituição até então tão atuante nove anos se passaram sem que tenha ocorrido à entrada de nenhum artefato arqueológico no MCC?

No que tange às primeiras 115 peças, elas alternam entre doadas e adquiridas nas incursões de campo, as demais lançadas no livro tombo 1 - que estão sob a denominação de 'saco' -, a partir de Riacho da Volta foram adquiridas por meio de trabalhos de campo. Entre as 115: 31 foram doadas, 43 não apresentam informações sobre doador ou indício de que tenham sido adquiridas (coletadas) em pesquisas de campo e 28 foram adquiridas pelo Departamento de Paleontologia. Destas 115 peças, algumas das quais fragmentadas, apenas 15 são cerâmicas e as outras são líticos.

A aquisição de peças a partir do 'saco 01' está relacionada conforme dito anteriormente aos materiais coletados no sítio Riacho da Volta. "Foram realizadas neste sítio 11 escavações, sendo um de mais de 20 metros de comprimento, sendo coletado em superfície e estratigrafia, material lítico e fragmentos de cerâmica" (LAROCHE, 1980: 20). Três campanhas de escavação neste sítio foram feitas somente no ano de 1979, respectivamente, nos meses de março, julho e setembro; além de vários participantes, as etapas de campo contaram, a julgar pelo que consta no livro de tombo, com coordenadores diferentes - os professores Vicente Giancotti Tassone, Iramar Araújo, Armand François Gaston Laroche e Adjelma Soares e Silva Laroche. O sítio foi escavado por cotas artificiais de $10 \mathrm{~cm}$, vindo em alguns trechos a alcançar a profundidade de $1,50 \mathrm{~m}$ (um metro e cinqüenta centímetros).

"Outro dado importante a acrescentar sobre o sítio arqueológico Bom Sucesso (Riacho da Volta) é a [sic] informações de que nas escavações realizadas na margem do riacho, foram coletadas amostras de carvão a uma profundidade de 1,20 metros, que resultou em uma datação de 9.000 anos BP" (LAROCHE, 1983; PROUS, 1992 e LEROI-GOURHAN, 1997 Apud SOUZA NETO et. al., 2005: 16 - grifo nosso). 
Para este sítio foi elaborada uma listagem à parte do livro tombo e a partir desta foi observado um total de 27.211 peças coletadas nos trabalhos de campo, sendo entre essas duas peças lítico-cerâmicas e outra cerâmica - as demais são líticos lascados (INVENTÁRIO DE COLEÇÕES ARQUEOLÓGICAS, 2006).

Após os materiais do sítio Riacho da Volta, tem-se as folhas que fazem referência a duas etapas de campo, julho de 1982 e fevereiro/março de1983, com alunos do curso de especialização em Arqueologia Pré-Histórica no sítio arqueológico Papeba, nas imediações das lagoas de Guaraíras e Papeba no município de Senador Georgino Avelino/RN. Contudo a referência 'saco' continua sendo utilizada, ao invés de um número de peça, de modo que dos vários materiais assinalados em apenas um caso, o 'saco' de número 0646, é possível se ter conhecimento do que se trata e neste caso se verifica que um 'saco' corresponde a 18 peças, sendo 12 de cerâmica, 4 líticos, 1 osso e 1 malacológico.

O registro de materiais arqueológicos, constantes nos livros de tombo, dos anos 1960 até os anos 1980 está restrito aos casos já citados. No final dos anos 1990 e início dos anos 2000 volta a ocorrer o registro de entrada de material arqueológico no Departamento de Arqueologia do MCC, mais exatamente em 1999 (86 peças) e 2000 (80 peças) coletadas em municípios do litoral e da área de transição do agreste para o sertão norte-rio-grandense.

O livro tombo toma digamos uma 'nova aparência' com a inserção dos materiais advindos dos trabalhos de campo na área de arqueologia por contrato, ao todo foram coletadas $8.630 \mathrm{em}$ atividades que se desenrolaram nos anos de $2003 \mathrm{e}$ 2004. Novos campos de informações foram criados, dando ao livro uma conformação diferente e o material passou a ser encaixado nas seguintes circunstâncias: amostra (isto para a seqüência de coleta da peça em campo), sítio, origem, coordenadas, cerâmico, lítico e um campo em branco destinado hora para observações, hora para datas; o campo 'data' foi adicionado em outro momento, assim como também foi criado o campo 'coletor' (figura 22). As mudanças feitas no livro tombo parecem à princípio evidenciar um maior controle no gerenciamento informações, entretanto, tornaram-no mais específico e menos abrangente, dadas 
essas circunstâncias como seria registrado, por exemplo, a entrada no museu por doação de uma peça de material ferroso?

Figura 22. Página 102 do $2^{\circ}$ Livro de Tombo, no alto os campos que foram criados para o registro das peças coletadas.

De fato, acreditamos que o livro tombo pode ser substituído por outros mecanismos de gerenciamento de informações e registros de peças, até cremos que o tratamento informatizado nos possibilitará uma visão mais integral dos dados gerados em trabalhos de campo ${ }^{25}$, ou até mesmo sobre peças que adentrarem em reservas técnicas pelas vias da compra ou da doação. Contudo, também acreditamos que a informação é o nosso passaporte para uma correta salvaguarda e, conseqüentemente, um elemento chave para a valorização do patrimônio (ALÇADA, 2007). Assim sendo, em um espaço onde um dos professores da casa por uma ocasião de uma mudança de chefia alegou que "não temos nenhuma

\footnotetext{
${ }^{25}$ Um exemplo deste tipo de iniciativa pode ser visto no artigo: "Da escavação ao museu: caminhos da informação", de Alexandre Matos (Práxis ARCHAEOLOGICA, oㅡ 2, 2007, p. 39 - 48). Neste texto, entre outros aspectos é apresentado o emprego de programas de computação como o 'In patrimonium', utilizados para o gerenciamento de informações em museus.
} 
relação oficial das coleções de material arqueológico" (LAROCHE, 1984), o controle da informação e, por conseguinte, sua capacidade de contribuir para a valorização de nosso patrimônio estão bastante prejudicadas.

\title{
Uma visão acerca da exposição permanente do Museu Câmara Cascudo e sobre a inserção da Arqueologia nesta expografia.
}

\begin{abstract}
"O acervo do MCC é composto por coleções, maquetas, miniaturas, reproduções de ambientes e peças avulsas, que fazem parte da exposição permanente e se encontram dispostos em dois pavimentos. Tal acervo caracteriza o perfil do MCC, que é voltado para as Ciências da Natureza, da Cultura e da Museologia, explorando as áreas da Anatomia Comparada, Malacologia, Paleontologia, Espeleologia, Antropologia, Arqueologia e Geologia Sedimentar. O número de peças registradas e catalogadas é de aproximadamente 2.500, existindo 3.500 a serem registradas e inventariadas, e outras peças nos departamentos de Arqueologia (cerca de 35.000 registradas, e, "n" peças a serem analisadas, registradas e inventariadas) e de Paleontologia composto de fósseis de invertebrados da Formação Jandaíra, Bacia Potiguar, e vertebrados típicos da megafauna quaternária do RN (cerca de 2.000 registradas e " $n$ " peças a serem estudadas, registradas e inventariadas)" (Fonte: www.mcc.ufrn.br).
\end{abstract}

\section{A exposição permanente do Museu Câmara Cascudo está distribuída em dois pavimentos, um térreo e o primeiro andar; em cada um dos pavimentos foram formadas duas alas, sendo que no térreo a exposição ocupa ainda um vão central. Neste vão há uma antiga canoa de pescadores e uma paliçada, em cujo interior estão alguns apetrechos de pesca, o cenário se completa com algumas 'beache rocks' e uma pequena piscina feita de}

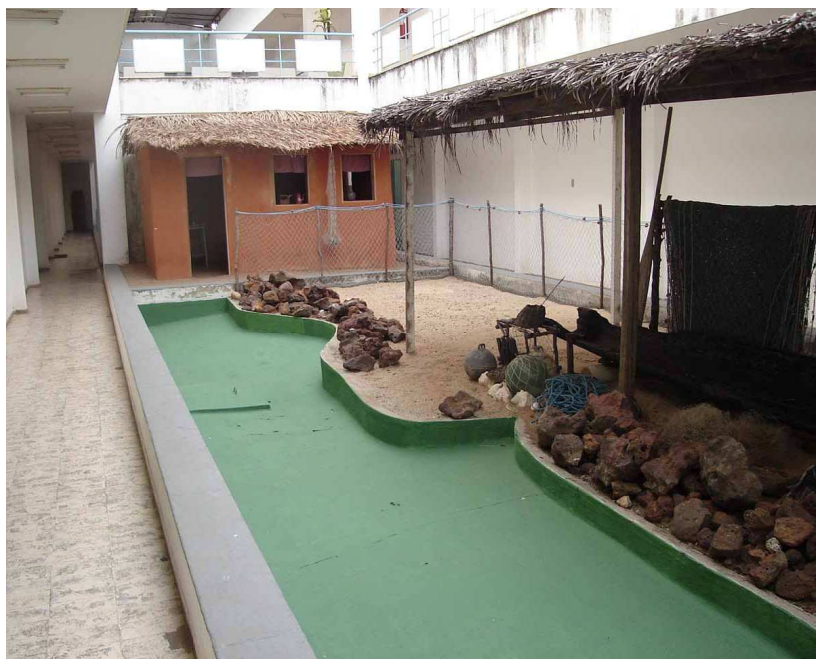

Figura 23. Cenário que se relaciona com a pesca artesanal no Rio Grande do Norte, ao fundo uma casa de taipa de pilão. maneira ondulada, a simular o avanço do mar, mais ao fundo deste cenário fica a réplica de uma casa de taipa de pilão (figura 23); logo em seguida, ainda no vão 
central, foi elaborada uma réplica de um sítio arqueológico do tipo sambaqui (figura 24).

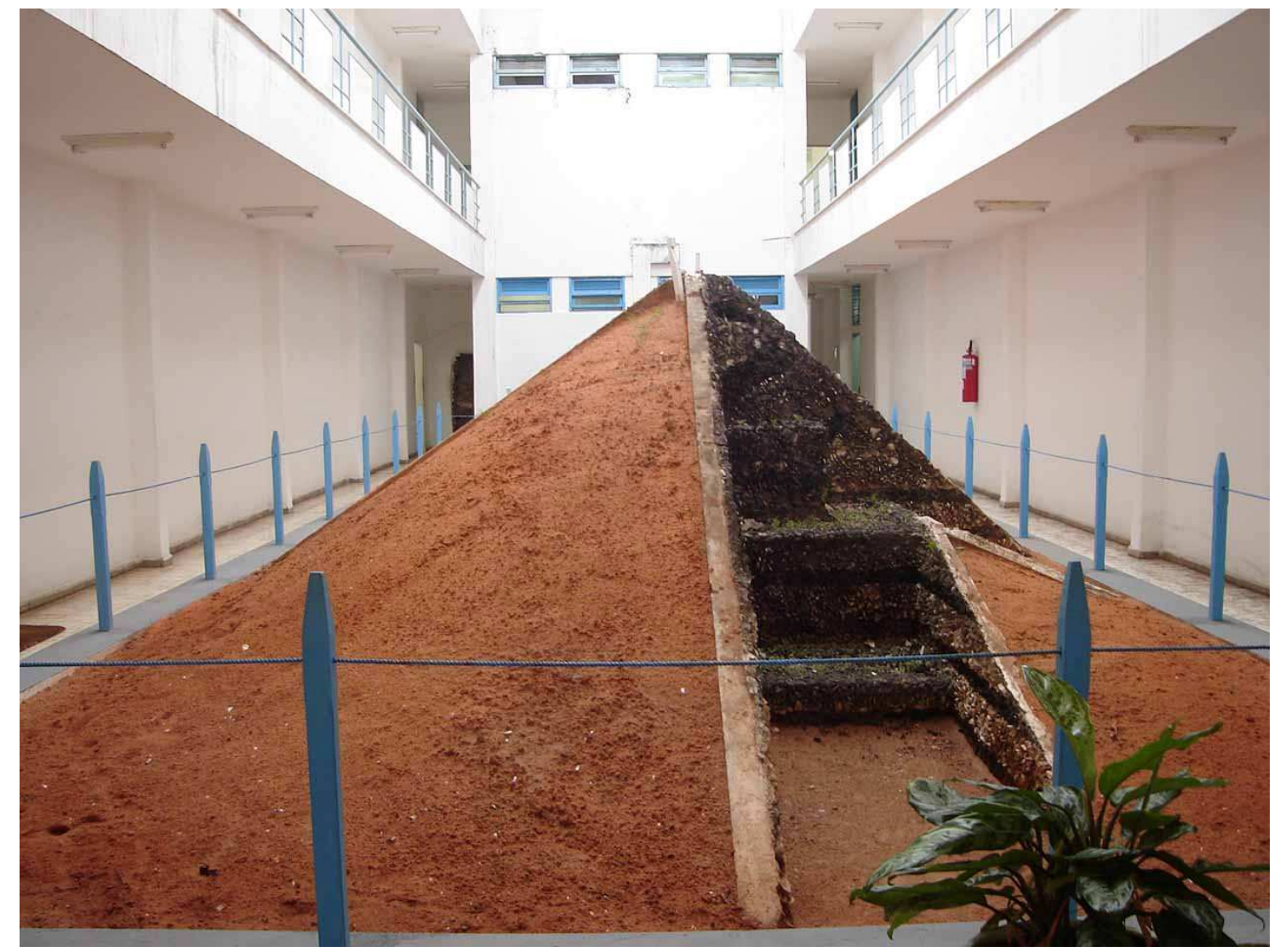

Figura 24. Maquete de um sítio arqueológico do tipo sambaqui.

A exposição continua em uma sala chamada de 'Reconstituição de Ambientes'. Neste espaço se buscou reconstituir um paleoambiente, isto através de um grande painel que ocupa toda a parede da sala e que é composto por imagens de animais da megafauna, desenhos de plantas e de formações geológicas, o cenário é complementado com a areia que foi espalhada em todo o piso, alguns troncos de árvores e pequenos animais empalhados, como tatus e uma preguiça. A presença destes animais torna possível relacionar a fauna e 0 ambiente contemporâneos ao de milhares de anos atrás. Está sala comporta ainda réplicas dos chamados 'tanques naturais', que são retratados tanto como reservatórios de água quanto como sítios arqueológico-paleontológicos, inclusive com uma réplica que mostra a estratigrafia destes sítios (figuras 25 e 26). 


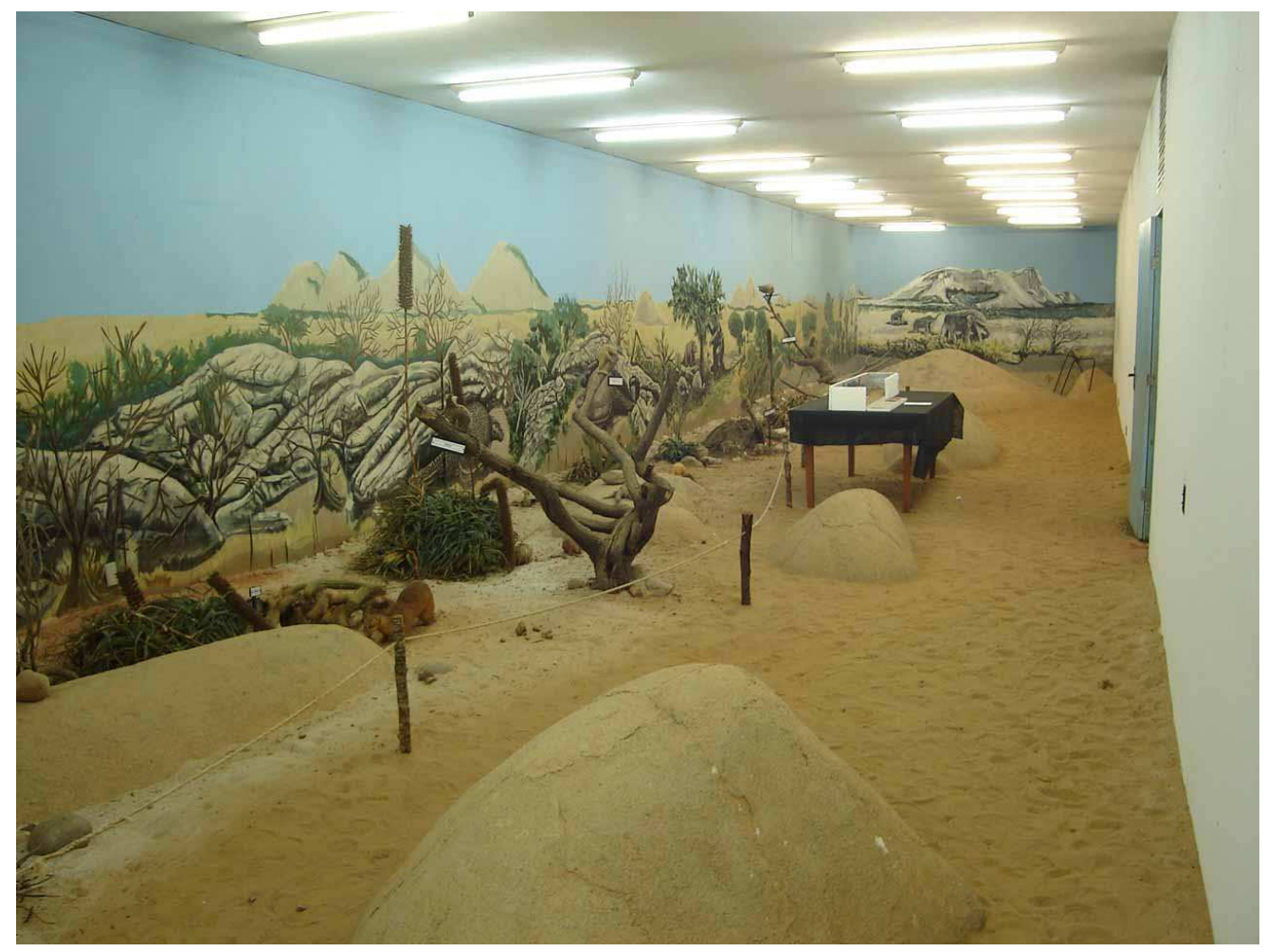

Figura 25. Sala de exposição que tenta recriar o ambiente pleistocênico.

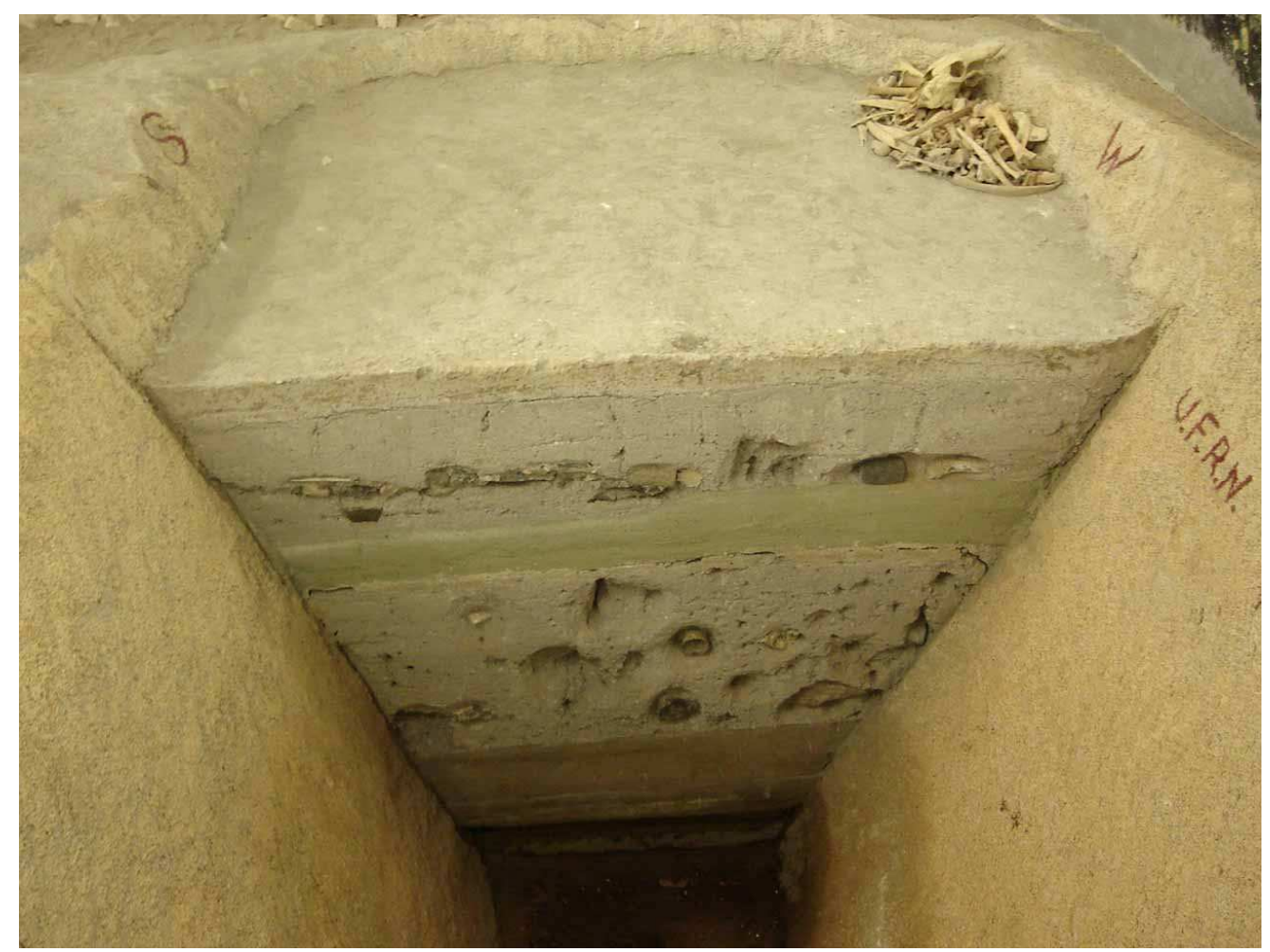

Figura 26. Simulação da estratigrafia de um sítio arqueológico/paleontológico do tipo tanque. 
Saindo desta sala entramos em um espaço dedicado ao ambiente cavernícola (figura 27), nesta sala foram recriadas situações semelhantes às encontradas em algumas cavernas do Rio Grande do Norte, inclusive, com morcegos morando lá. Acompanhando o circuito de exposição, observamos que a geologia do estado é algo que continua também sendo abordado na primeira sala, da segunda ala do piso térreo. Neste espaço foi feita uma réplica de uma das mais importantes minas potiguares, a Mina Brejuí (figura 28). Além das miniaturas dos mecanismos usados na lavra dos minérios, a sala conta ainda com um pequeno túnel ao longo do qual o visitante tem a oportunidade de ver alguns dos principais minérios explorados em terras potiguares. As réplicas desta sala foram financiadas pela própria Companhia de Mineração Tomaz Salustino S. A. e doadas ao Museu Câmara Cascudo em 1975. Esta mina se localiza no município de Currais Novos/RN e no auge da mineração de scheelita foi um dos principais motores econômicos o estado, isto dos idos de 1960 a 1980.

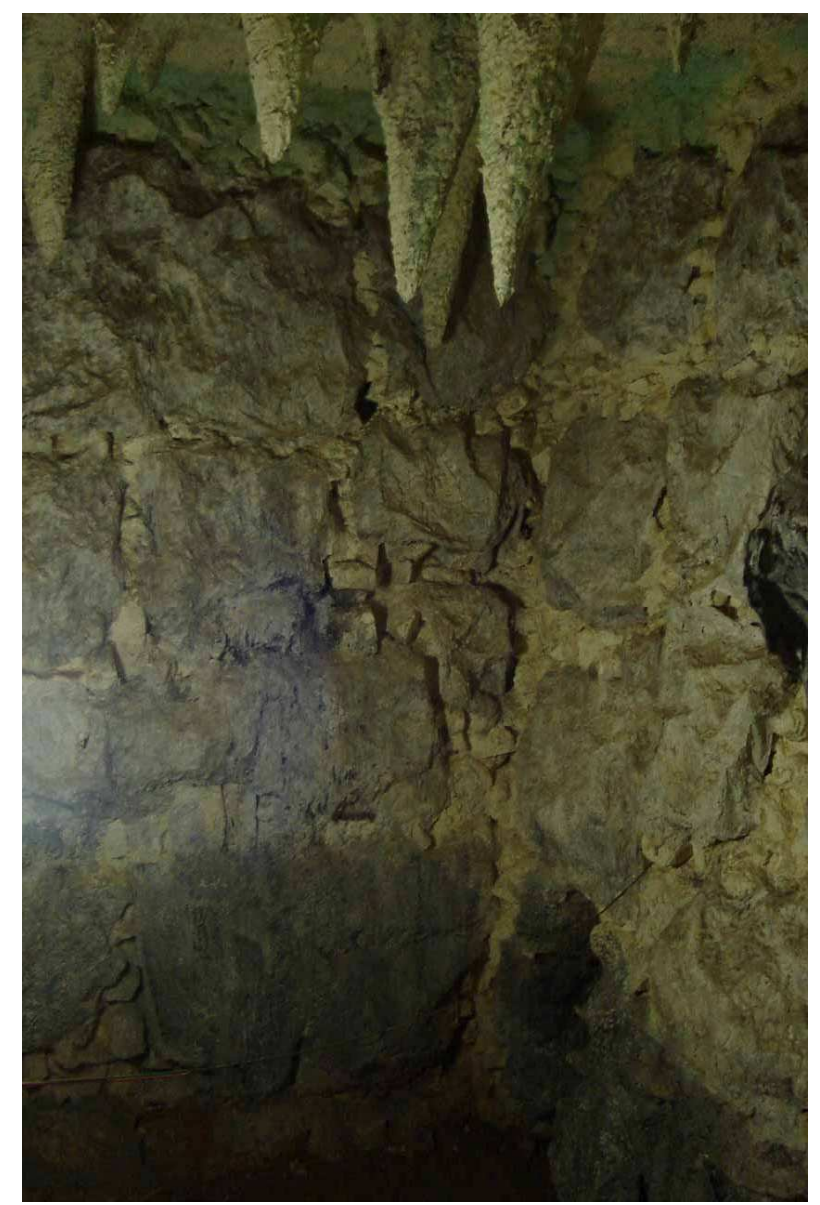

Figura 27. Sala que recria o ambiente cavernícola. 


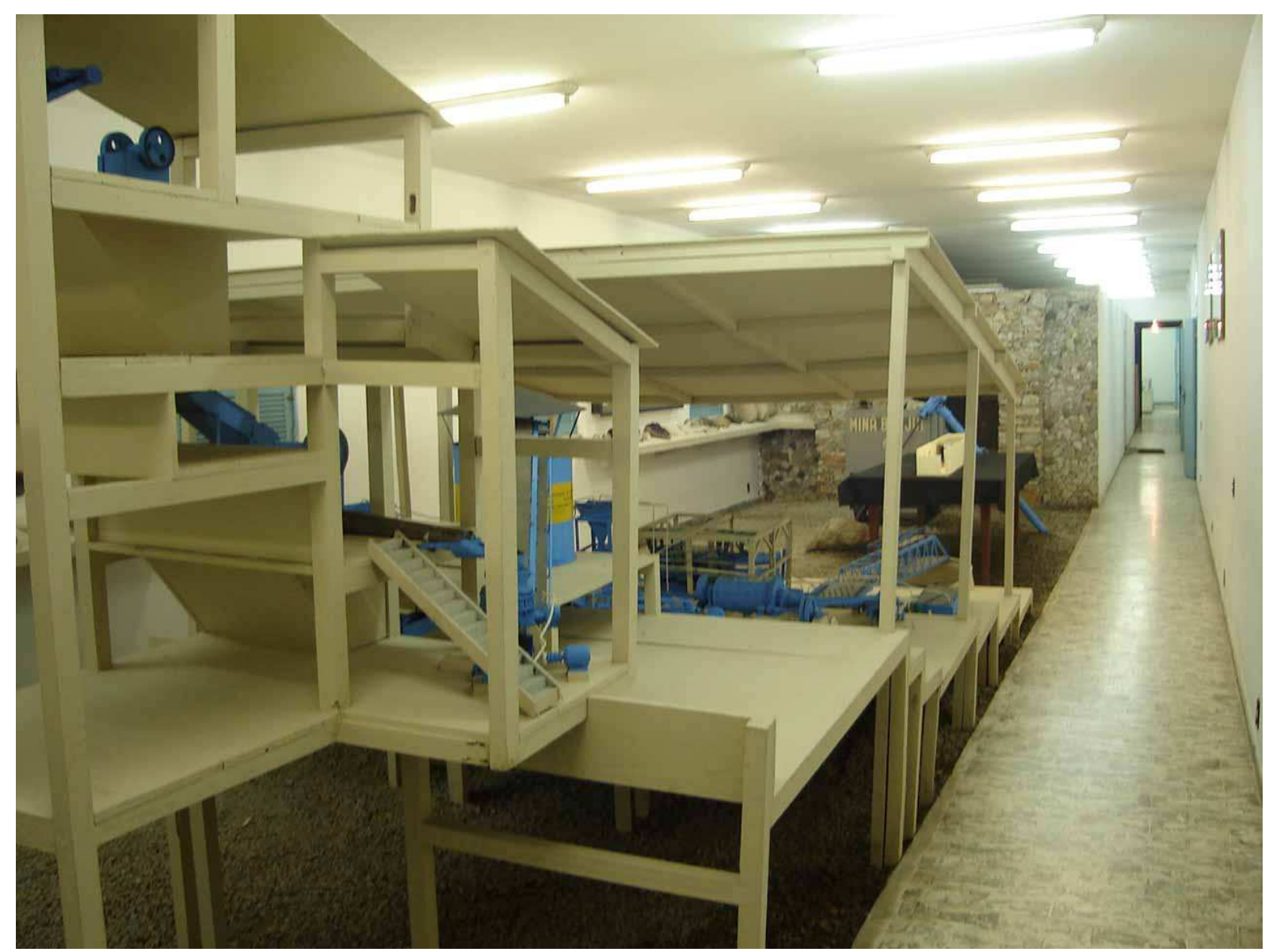

Figura 28. Réplica da Mina Brejuí, Currais Novos/RN, doada ao Museu Câmara Cascudo no ano de 1975 pela companhia de Mineração Tomaz Salustino.

Outro pólo da atividade econômica do Rio Grande do Norte, mas este inclusive nos dias atuais, é abordado na chamada 'sala do Sal'. O estado é o maior produtor de sal do país (produz mais de 90\% do sal consumido no país) e esta sala conduz o visitante por aspectos relativos à industrialização e aos produtos derivados do sal, além de enaltecer as potencialidades da chamada 'Costa Branca' - a região norte-rio-grandense onde é produzido o sal e a sala foi elaborada com recursos da salina Diamante Branco, em 1999.

A última sala do piso térreo a ser visitada trás maquetes do Pico do Cabugi, um neck vulcânico remanescente de um vulcão do terciário que situa-se a 590 metros acima do nível do mar, e de uma mapa do Rio Grande do Norte, onde são representadas as principais feições geomorfológicas do estado, assinaladas as principais cidades e delimitadas as áreas de exploração do sal e do petróleo. 
A primeira sala do piso superior tem em sua composição elementos ligados a arte da olaria no estado, somam-se alguns objetos do cotidiano e algumas imagens de santos feitas por sertanejos. Ao sairmos dessa sala, entramos em um bloco de salas de elaboração mais recente (em 2006) e que se distribui por cores diferenciadas, delimitando os espaços e apresentando temáticas que vão desde a arte e a religião afro-brasileiras até a etnografia indígena, passando por aspectos relativos ao folclore e vida religiosa norte-rio-grandense e pela arqueologia.

A primeira destas salas é azul escura (figura 29) e aborda temáticas relativas à cultura e religiosidade afro-brasileiras, conta com algumas peças doadas de um museu em Luanda, capital da Angola e evidencia o fenômeno do sincretismo religioso estabelecendo em seu texto de exposição, a associação entre santos católicos e divindades africanas - algumas das quais são representadas nesta sala por pinturas e não por imagens de gesso.

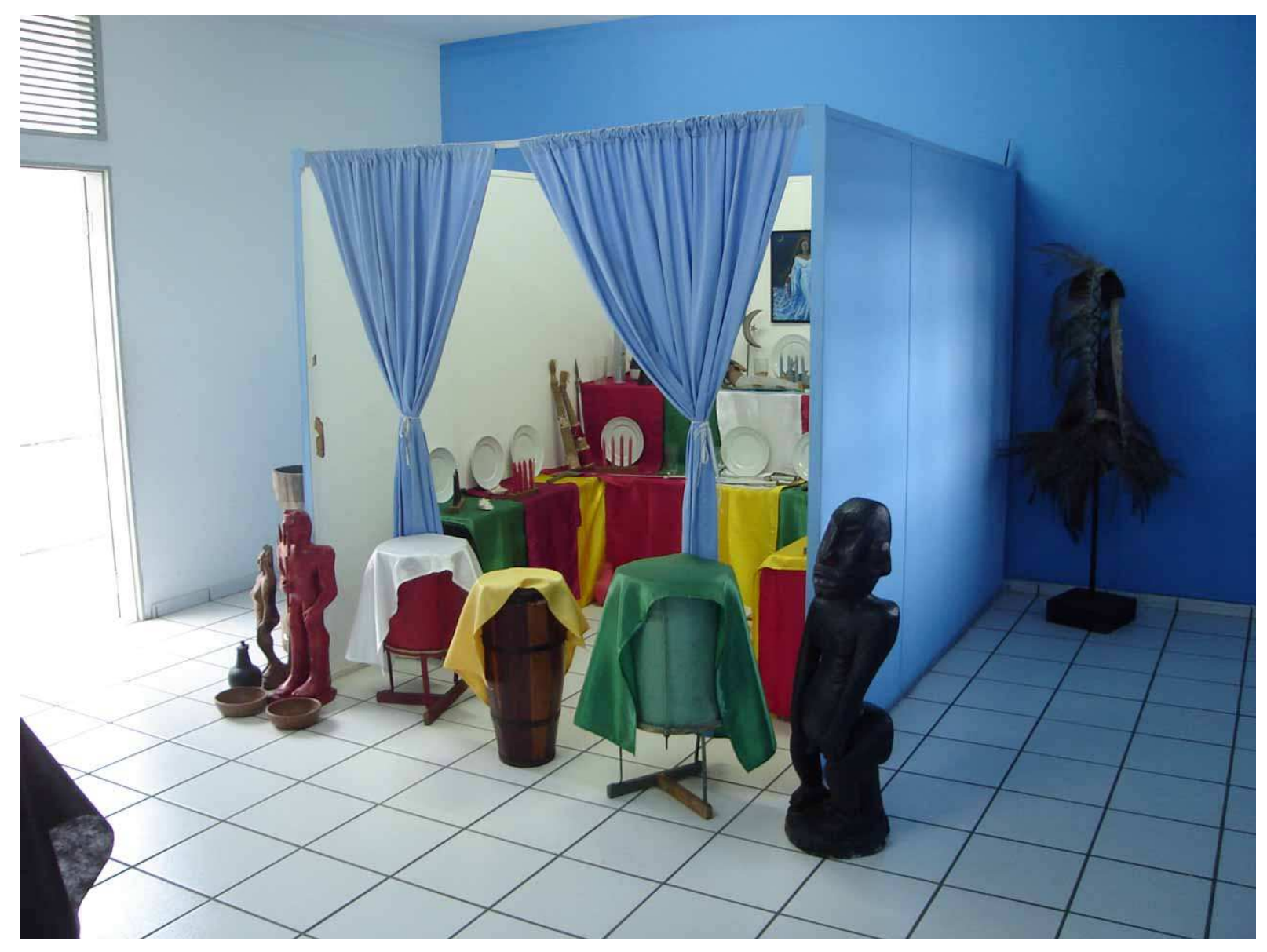

Figura 29. Sala da Arte e Religião Afro-Brasileiras. 
Ao sair da sala azul entramos em uma sala cor de rosa (figura 30), onde foi elaborada uma exposição acerca de uma brincadeira da cultura norte-riograndense, um teatro de bonecos que recebe o nome de mamulengo, ou pode ser também chamado de 'João Redondo', nome da personagem mais conhecida no estado e que é retratada por quase todo mamulengueiro. A sala seguinte está em tom lilás, chama-se 'Santeiros e Devoções' (figura 31) e como o próprio nome já deixa claro tem uma abordagem religiosa, por meio da exposição de imagens sacras e de 'ex votos', símbolos de fé na realização de milagres.

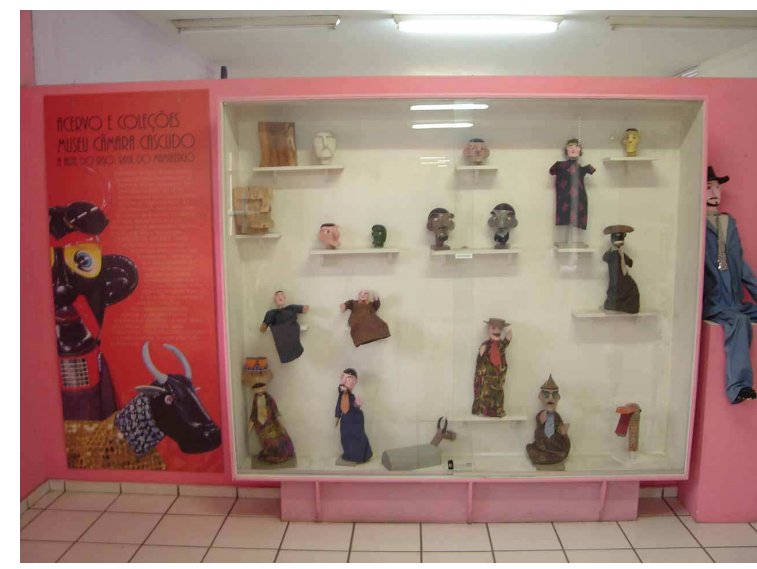

Figura 30. Sala dos mamulengos.

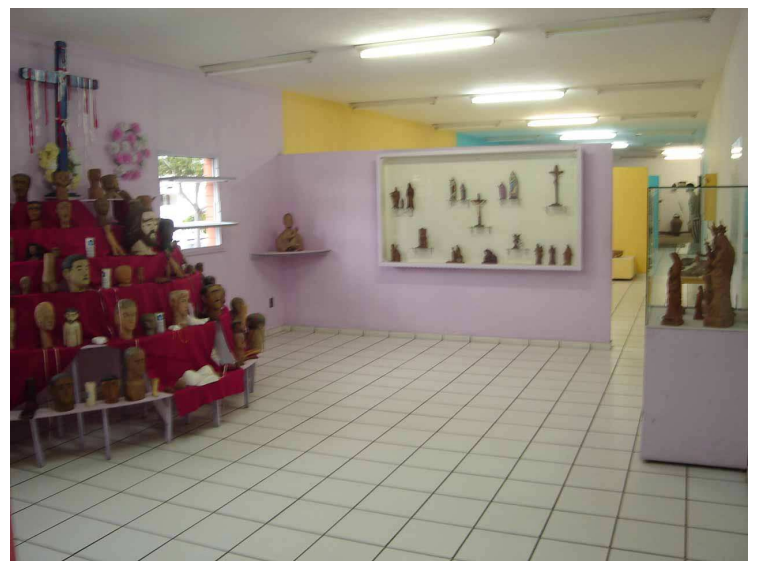

Figura 31. Sala 'Santeiros e Devoções'.

A sala amarela é a que comporta parte da coleção arqueológica do MCC (figura 32), compõem esta sala seis peças cerâmicas, duas vasilhas inteiras e outras 4 reconstituídas, dois expositores, um com vasilhames cerâmicos e artefatos líticos polidos e o outro com artefatos líticos lascados. Em uma das paredes da sala figura um mapa com marcações sobre sítios arqueológicos no Rio Grande do Norte. As cerâmicas expostas foram coletadas na época do PRONAPA pelo professor Nássaro Nasser e são vinculadas a Fase Curimataú, já os artefatos líticos lascados, os artefatos polidos e as cerâmicas dos mostruários (figura 33) se encontram sem nenhuma referência e também não foi possível identificá-los na documentação analisada, portanto são de origem desconhecida. Existe ainda um texto informativo que foi composto a partir de citações das arqueólogas Madu Gaspar e Gabriela Martin (figura 34). 


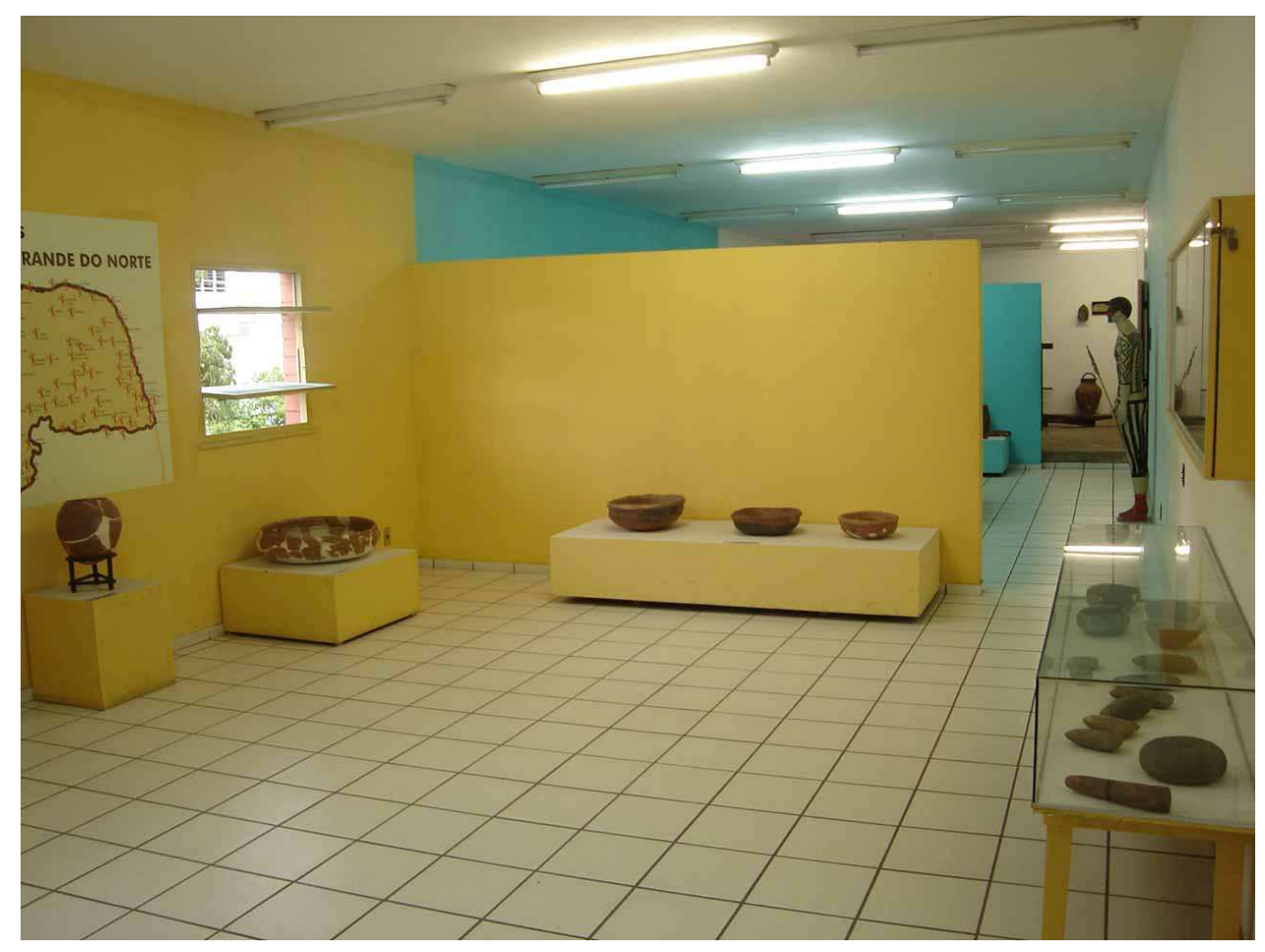

Figura 32. Sala dedicada a Arqueologia e Pré-História norte-rio-grandenses.

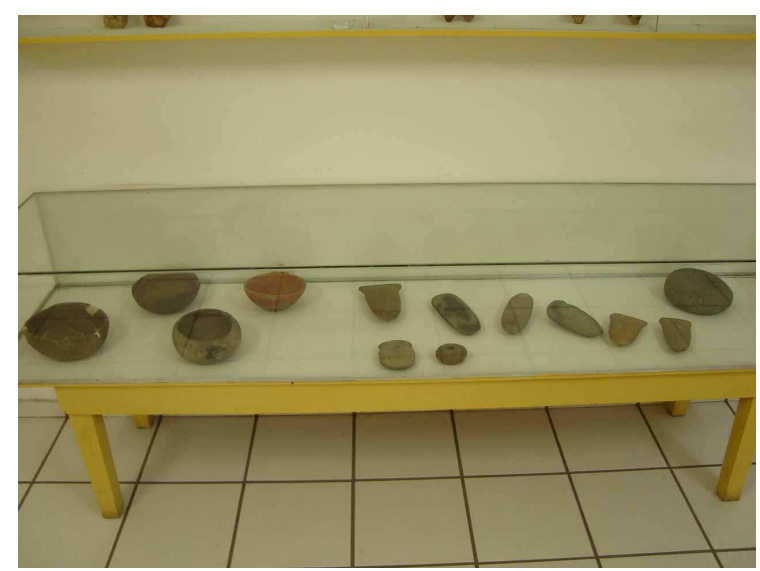

Figura 33. Mostruário com artefatos líticos polidos e vasilhames cerâmicos.

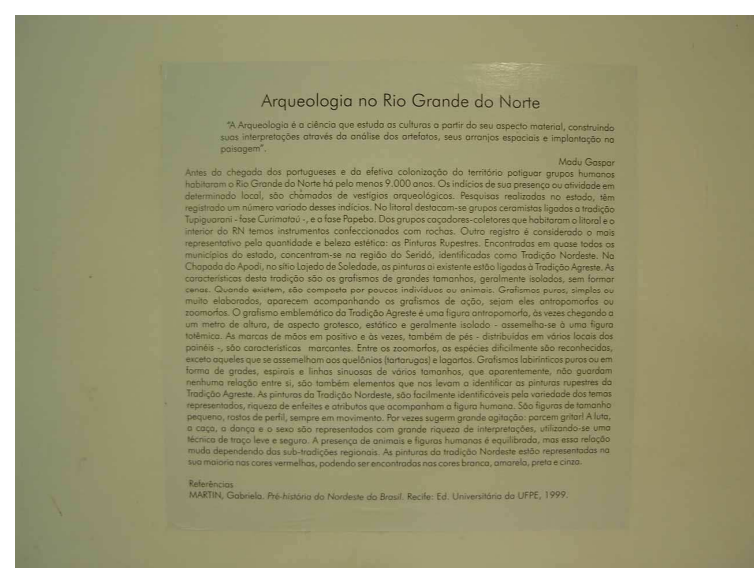

Figura 34. Texto explicativo sobre 'arqueologia no Rio Grande do Norte'.

A sala azul claro, última do circuito com cores diferentes, é dedicada a Etnografia. Há um mostruário desocupado e o outro com, entre outras peças, plumária indígena. Existem ainda exemplos de cestaria e um manequim, que simula um indígena com pintura corporal. A sala seguinte é dividida em dois ambientes, um dedicado ao ciclo da cana-de-açúcar (importante atividade econômica do Brasil 
colonial, cujos principais plantios se localizaram no nordeste, figura 35) e o outro, abordando a manufatura do couro no interior do estado.

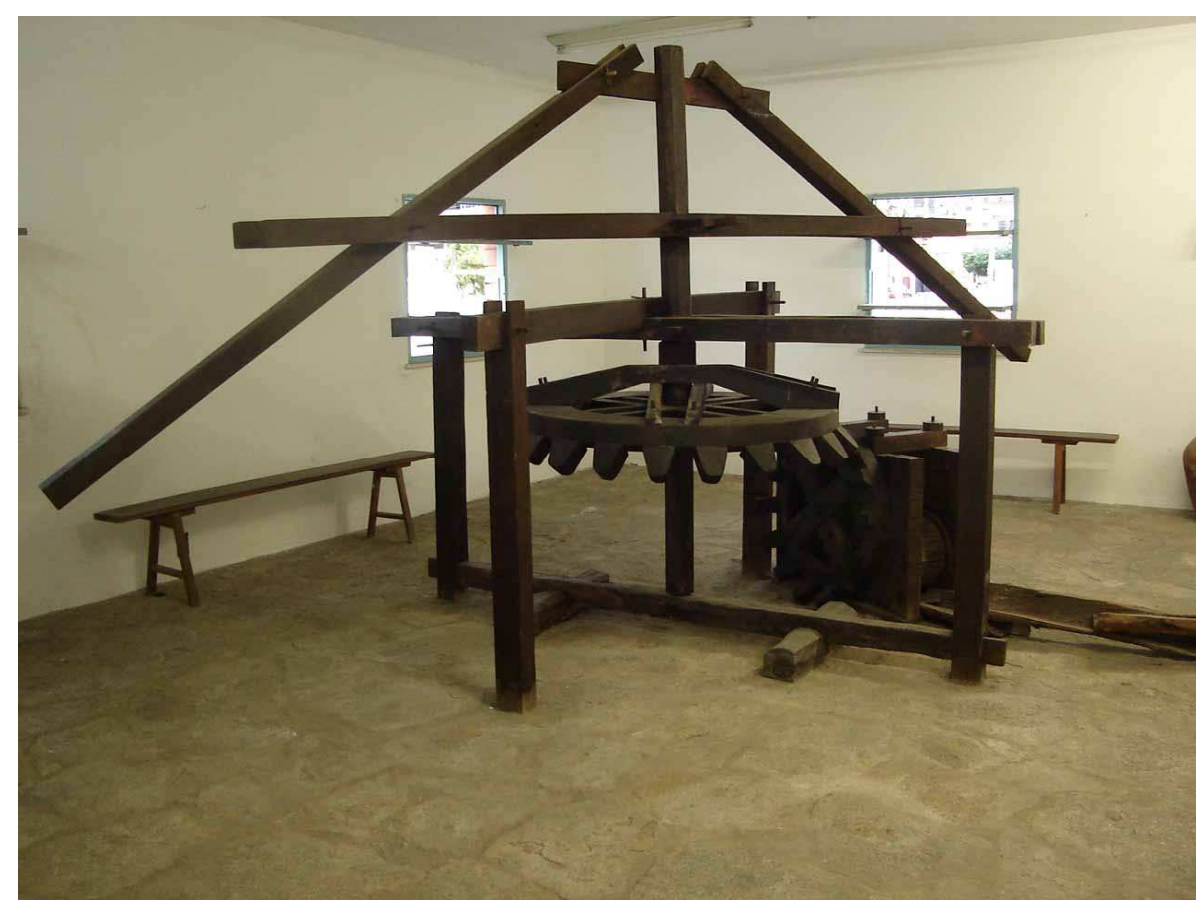

Figura 35. Moenda de cana-de-açúcar, na sala dedicada ao Ciclo da Cana-de-açúcar.

A antepenúltima sala é dedicada à paleomastozoologia, nesta figuram fósseis de animais pleistocênicos (figura 36) encontrados em cavernas, tanques, ravinas e paleolagoas do estado. O bloco paleontológico da exposição é complementado na sala seguinte, com uma exposição relacionada aos dinossauros onde estão presentes moldes em gesso de pegadas de paleomastozoologia.

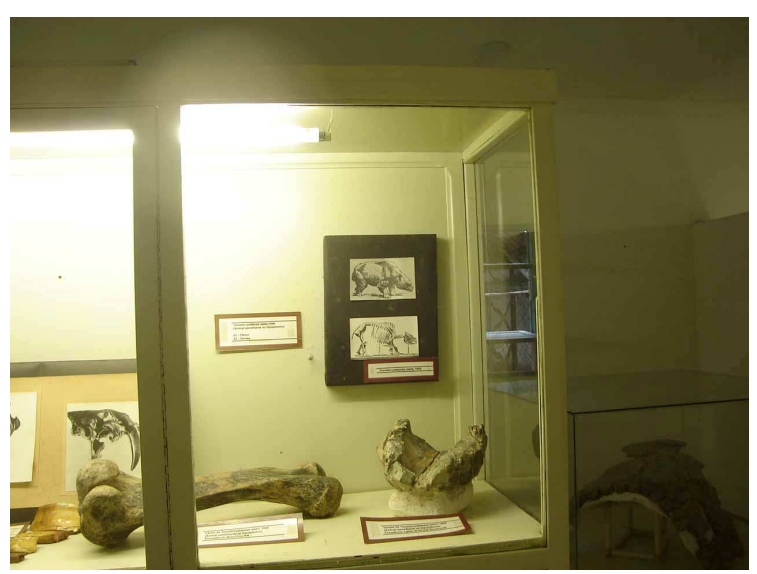

Figura 36. Sala dedicada a

dinossauros, originárias de Souza na Paraíba. Complementa a sala, um painel com pinturas de dinossauros (figura 37). A última sala da exposição é bem ampla (figura 38) e se destina a anatomia comparada, estão dispostos vários esqueletos 
recompostos de animais desde um cachorro até a uma baleia, além disso, há mostruários com ossos que se prestam a comparação entre espécies.

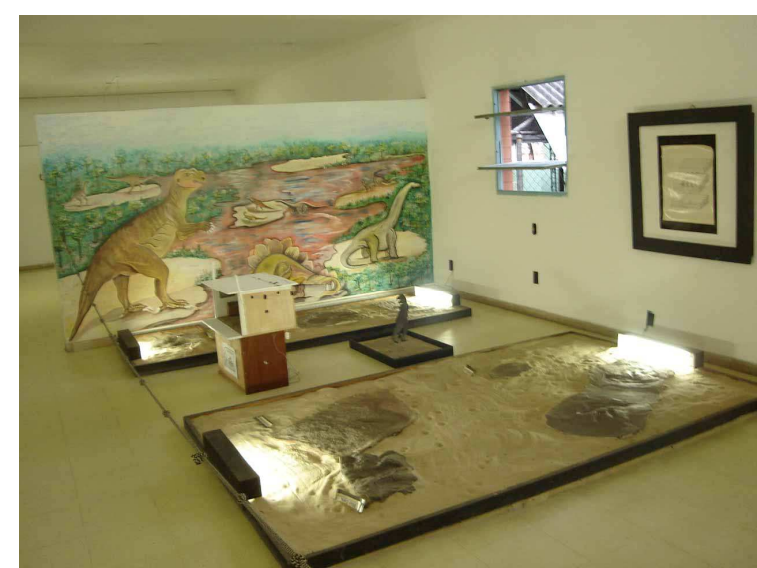

Figura 37. Sala da paleontologia, com o painel dos dinossauros ao fundo.

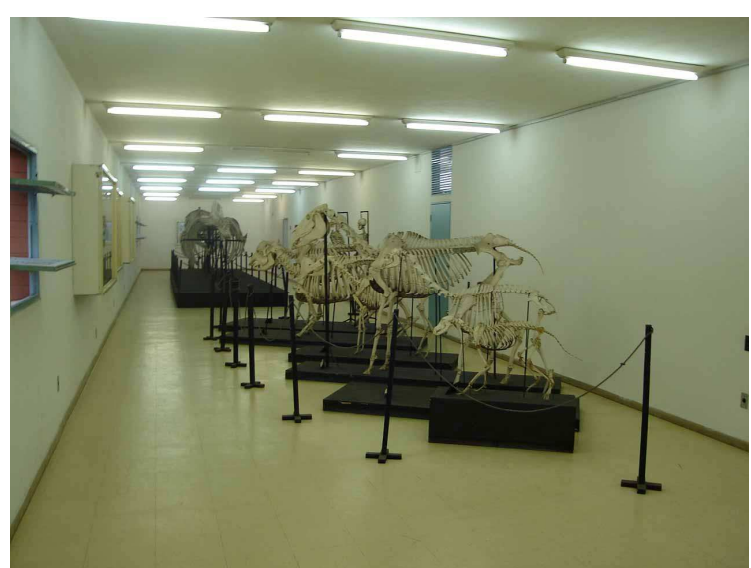

Figura 38. Sala da anatomia comparada.

A exposição permanente do Museu Câmara Cascudo foi elaborada originalmente na segunda metade dos anos 1970, de lá para cá a exposição tem se mantido substancialmente a mesma. Quando foi elaborada na década de 1970 a exposição representava algo de vanguarda em termos do cenário museológico brasileiro, o fato de se conduzir o visitante por áreas como a que recria o ambiente pleistocênico era um fator novo que ia além da reconstituição de contextos em vitrines feita em algumas instituições, no caso do MCC essa reconstituição está mais ao alcance do público visitante que ao caminhar se vê ladeado por evidências de um passado distante.

Apesar de manter parte do seu projeto original, a exposição foi acrescida por elementos como pequenas maquetes que reproduzem em miniaturas os elementos que compõem as salas de exposição ${ }^{26}$. Além disto, outras salas foram criadas, como 'A Sala do Sal', e algumas tiveram seus projetos re-elaborados, como as salas com cores diferenciadas que deram uma nova formatação ao circuito de exposição.

\footnotetext{
${ }^{26}$ Essas réplicas das salas de exposição foram feitas em um projeto do professor Dr. José Sávio Oliveira de Araújo, do Departamento de Artes da Universidade Federal do Rio Grande do Norte, no ano de 2006 e depois de doadas ao museu foram agregadas às salas de exposição.
} 
Apesar das modificações, as salas que comportam elementos relativos às atividades de setores tradicionais do museu, como no caso a Geologia e a Paleontologia foram em pouco, ou em nada, alteradas. Inclusive, é perceptível que as salas do paleoambiente e a do ambiente cavernícola representam o maior poder político-institucional que o então Setor de Geografia/Geologia possuía quando da elaboração desta exposição. Um caso típico dessa situação é também a Sala da Anatomia Comparada, uma herança do, outrora forte, Departamento de Genética do Museu Câmara Cascudo que hoje se encontra desativado devido à criação de um departamento homônimo no Centro de Biociências da Universidade Federal do Rio Grande do Norte. Não esqueçamos também, por exemplo, que quando esta exposição foi pensada o Setor de Arqueologia passava por uma forte diminuição nas atividades e carecia de profissionais, os quais só vieram em fins dos anos 1970 .

Aliás, o modo como a arqueologia está inserida nesta proposta expográfica já foi alvo de críticas há mais de sete anos, por ocasião da elaboração de um relatório sobre o material arqueológico em exposição e na reserva técnica. As conclusões deste relatório serão por nós transcritas a seguir:

"A principal dificuldade encontrada pela equipe responsável por este levantamento foi causa pela ausência de um livro de tombo ou registros do departamento de museologia, onde deveria constar: o registro de origem, de procedência (departamento), número, identificação, o controle de entrada e saída das peças, tornando possível a comparação desses dados com os que foram entregues pela equipe de museologia. A não existência deste livro criou duas situações críticas: uma primeira, que foi a existência de um número de peças 'desaparecidas' e outras existentes sem registro. Apesar das dificuldades encontradas foi feito um levantamento com fichamento de todo material arqueológico analisado. As fichas encontram-se sob a responsabilidade dos pesquisadores.

Em relação ao material e forma de exposição da coleção arqueológica, apresentamos as seguintes sugestões:

3.1. A criação urgente de um livro de registro de todo o material existente do departamento de museologia.

3.2. A correção dos erros explicativos de algumas peças em cerâmica que se apresentam como urnas funerárias e que na realidade são cerâmicas utilitárias.

3.3. A localização das peças 'desaparecidas'.

3.4. A dedetização qualificada e urgente da canoa em exposição, na tentativa de salva-la dos cupins que estão atacando-a. 
3.5. Retirada do Sambaqui já que este tipo de registro arqueológico não faz parte do nosso patrimônio pré-histórico.

3.6. Mudança na estrutura da exposição:

3.6.1. Novos painéis com pinturas rupestres.

3.6.2. Mudança das vitrines que são totalmente inadequadas para a exposição de material arqueológico.

3.6.3 Elaboração de painéis com texto simples e claro com ilustrações de uso das peças.

3.6.4. Priorizar o acervo pertencente ao $\mathrm{RN}$ com peças provenientes do próprio Museu Câmara Cascudo.

3.6.5. Atualização do mapa do $R N$ com a localização e identificação dos sítios arqueológicos.

3.6.6. Os quadros da exposição sobre as escavações devem ser agrupados formando um mural" (OLIVEIRA \& AZEVEDO, 2000).

As ponderações acima nos remetem, em um primeiro momento, a percepção de que os museus não cuidam de sua própria memória. Sobre a gestão no Departamento de Museologia, cumpre dizer que foi elaborada uma reserva técnica e hoje existem funcionários que cuidam do registro e alocação das peças. O acervo de arqueologia não está integrado a essa reserva técnica e fica todo ele, excetuando pelo que está em exposição, no próprio Departamento de Arqueologia. A julgar pelo atual estado dos mostruários onde estão expostos os artefatos arqueológicos, a única modificação que ocorreu foi à retirada destes.

AZEVEDO \& ROCHA fazem referência a "peças que 'desapareceram'”, o controle sobre o gerenciamento das peças arqueológicas nunca foi bem conduzido no Departamento de Arqueologia, conforme pôde ser visto em outro momento deste capítulo (quando o professor Laroche alegou não ter conhecimento das coleções de materiais arqueológicos), e a julgar pelas palavras destes pesquisadores também não foi um ponto forte no Departamento de Museologia. Este na realidade acabou se revelando um problema crônico e pode ser apontado como um dos motivos que explicam a ausência, ainda nos dias atuais, de peças arqueológicas coletadas em trabalhos de campo ou doadas ao Museu Câmara Cascudo.

A canoa citada por AZEVEDO \& ROCHA, que anteriormente se pensava ser uma peça arqueológica, hoje figura no trecho da exposição dedicado a pesca artesanal no estado do Rio Grande do Norte. 
$\mathrm{Na}$ exposição permanente do Museu Câmara Cascudo, apenas duas situações não se coadunam com as terras norte-rio-grandenses, as pegadas de dinossauro (algo que até os dias atuais não foi encontrado no estado) e a réplica de um sítio arqueológico do tipo Sambaqui. A sugestão feita no ano dois mil não foi acatada e a réplica continua a figurar no pátio de exposição do museu. Situando sua elaboração em uma perspectiva cronológica e lembrando que quando o Instituto de Antropologia foi criado um dos primeiros temas escolhidos para pesquisa fora 'os sambaquis do Rio Grande do Norte', podemos pensar que a presença deste tipo de sítio em meio à exposição reflete na realidade uma perspectiva de pesquisa, algo que com o passar dos anos não foi comprovado e que por isso, uma vez que as referências a serem trabalhadas na exposição deveriam ser antes de tudo potiguares, deveria ser retirado tendo em vista uma melhor apreensão por parte dos visitantes das referências pré-coloniais norte-rio-grandenses por excelência.

Com exceção da 'prioridade ao acervo do $\mathrm{RN}$ e das pesquisas provenientes do Museu Câmara Cascudo' e de 'um mapa com a localização de sítios arqueológicos', nenhuma das outras mudanças propostas foi acatada. De maneira que o único texto explicativo da exposição é feito a partir de citações de autoras consagradas nacionalmente na área de arqueologia, não tenho nada contra o apoio em tais autores, mas será que é realmente necessário este apoio depois de tantos trabalhos de pesquisa arqueológica desenvolvidos e publicados? Será que não seria mais oportuno se valer da produção desta própria instituição para explicar 0 acervo que foi por eles adquirido?

A Arqueologia no Museu Câmara Cascudo se encontra exilada na própria casa que the deu abrigo, que contribuiu para a formação de seus profissionais e que agora restringe seu lugar na exposição, que limitou em seu processo de extroversão a capacidade comunicacional dos bens pré-coloniais e que deixou amostra mais uma camada da estratigrafia do abandono em museus potiguares. Quais serão então as outras camadas que iremos desvelar nos museus do Sertanejo, do Seridó e no Museu de Soledade? 


\section{CAPÍTULO IV}

Da Fundação Amigos do Lajedo de Soledade ao museu universitário: outros aspectos da Musealização da Arqueologia no Rio Grande do Norte. 
As discussões feitas anteriormente sobre o Museu Histórico Lauro da Escóssia e também sobre o Museu Câmara Cascudo, em certa medida se assemelham ao quadro observado em parte deste capítulo, ou seja, também identificamos acervos arqueológicos que não são trabalhados de uma maneira educativa ou que não se relacionam com outros conjuntos patrimoniais e encontramos, da mesma forma como no caso do MCC, uma produção acadêmica, levada a cabo por pesquisadores ligados ao NEA/UFPE (Núcleo de Estudos Arqueológicos da Universidade Federal de Pernambuco), que não é usada em espaços museais para contribuir com os aspectos comunicacionais das fontes de nosso passado pré-colonial. Contudo, lidamos com uma situação que ainda não foi trabalhada nesta dissertação e que compõe a outra parte deste capítulo, isto é, conhecemos um projeto arqueológico que teve seu produto musealizado e que na base desse processo houve uma participação popular.

Lidamos a partir de agora com duas situações limítrofes, de um lado observamos uma região que possui museus e, embora pequenos, acervos arqueológicos, mas que fundamentalmente é uma área onde são desenvolvidas pesquisas há mais de vinte anos e cujos resultados figuram em artigos científicos, dissertações e teses, sem que isto signifique um retorno para a população local e sem que esta mesma população conheça os bens retirados dos sítios arqueológicos de sua circunvizinhança. Do outro lado, saindo do Seridó para o Oeste do Rio Grande do Norte, temos uma experiência, onde atrelado à pesquisa vieram mecanismos de extroversão dos bens arqueológicos, trabalhos de conscientização patrimonial e, também, geração de emprego e renda.

Assim, começaremos por um histórico das pesquisas arqueológicas na área do Seridó e, uma vez mapeados estes estudos, abordaremos os museus do Sertanejo e do Seridó, tendo em vista pensarmos não só a Musealização da Arqueologia nestas instituições, como também ponderarmos as situações opostas entre esses acervos e o que foi coletado ao longo de escavações em sítios arqueológicos do Seridó norte-rio-grandense. Na seqüência abordaremos aspectos relativos à pesquisa arqueológica no Lajedo de Soledade e o caso da formação do Museu de Soledade. 


\section{Um pequeno histórico das pesquisas arqueológicas no Seridó potiguar.}

A região Seridó é uma área no centro-sul do Rio Grande do Norte que faz divisa, ao sul com a Paraíba. Região de seca intensa sobrevive economicamente da produção de cerâmicas construtivas e da extração de minérios, pedras semipreciosas e inclusive minerais estratégicos como o urânio. É um espaço dividido em duas mesorregiões, o Seridó Ocidental e o Seridó Oriental, na porção ocidental fica o Museu do Seridó (cidade de Caicó) e na banda oriental fica o Museu do Sertanejo (cidade de Acari).

As pesquisas arqueológicas estão centralizadas no Seridó Oriental, principalmente, nos municípios de Carnaúba dos Dantas e Parelhas. Estes trabalhos vêm ocorrendo desde a década de 1980 e tiveram como motivação o grande número de sítios rupestres que apresenta a região. Vários sítios arqueológicos foram escavados, dentre os quais figuram Pedra do Chinelo e Boqueirão - no município de Parelhas -, Pedra do Alexandre, Casa Santa e Serrote das Areias - em Carnaúba dos Dantas. Paralelo a isso, outros tantos foram identificados e/ou prospectados, como no caso dos sítios Xique-Xique (1, 2, 3, 4), Talhado do Gavião ou o sítio do Messias.

Outro elemento que evidencia a importância desta área para a arqueologia norte-rio-grandense, e nordestina de uma maneira mais ampla, é a quantidade de sítios identificados. Por exemplo, no município de Carnaúba dos Dantas um levantamento feito pela equipe do GEPS (Grupo de Estudos em Patrimônio e Arqueologia do Seridó) diagnosticou a presença de mais de 60 sítios arqueológicos com pinturas rupestres, nem todos apresentam sedimento ou são do tipo 'abrigo sob rocha', mas evidenciam uma ocupação intensiva da área há vários milênios. Como diziam os antigos moradores de Carnaúba dos Dantas, 'as pinturas são do tempo da onça' - em referência ao tempo em que este tipo de animal existia na região.

Sítios arqueológicos com gravuras e pinturas rupestres são comuns a todo o Seridó, entretanto, os sítios que se encontram no vale do rio Seridó e de seus dois principais afluentes, o Acauã e o Carnaúba, são vinculados a uma subtradição 
da Tradição Nordeste ${ }^{27}$ de pinturas rupestres, chamada subtradição Seridó. Esta subtradição, entre todas as subtradições da Tradição Nordeste, é segundo Gabriela Martin "a que tem apresentado maior riqueza de elementos porque tem sido mais estudada" (MARTIN, 2007: 8).

Mais estudada, significa dizer que além das análises sobre os elementos cenográficos, através da decomposição de painéis de registros gráficos, os sítios arqueológicos da subtradição Seridó, localizados no Rio Grande do Norte, renderam várias informações no que diz respeito, por exemplo, a ritos funerários e a cultura material.

O sítio Pedra do Alexandre não foi um dos primeiros a ser escavado ( a escavação deste sito ocorreu em 1991), contudo foi o que mais rendeu informações em termos da cronologia para a ocupação do Seridó em tempos pré-históricos. Há uma seqüência de datações que vai de 9.410 a 2.620 anos antes do presente. Estas datas junto com as obtidas em alguns sítios escavados pela equipe de arqueologia do Museu Câmara Cascudo, são as únicas referências cronológicas para o passado pré-colonial potiguar e 9.410 anos AP é a evidência de presença humana mais antiga no estado.

As pinturas rupestres do sítio Pedra do Alexandre são em tons vermelho e amarelo, a matéria-prima de onde proviam os pigmentos é encontrada em um raio máximo de 4 quilômetro de distância, no sítio foram coletados em níveis estratigráficos 83 fragmentos de óxido de ferro, que após datações oscilaram entre 4 mil e 5 mil anos antes do presente, estes fragmentos manifestaram sinais de uso e a cronologia apontada passou a ser um indicador de época para a confecção das pinturas rupestres (TORRES, 1995/1996). O vermelho também está presente em ossos dos indivíduos enterrados no sítio, foram escavados 28 sepultamentos sendo que um destes era o de um animal. A pigmentação vermelha foi encontrada nos

\footnotetext{
27 "Na década de oitenta se estabeleceram duas macro-categorias básicas na sistematização inicial da arte rupestre no nordeste do Brasil que se chamaram Tradição Nordeste e Tradição Agreste que demonstraram uma marcada complexidade e sua evolução no tempo e no espaço. [...] A partir dessas categorias ou tradições, foram criadas subtradições que nós classificamos como núcleos emigrados do núcleo central para outras regiões estabelecidas em áreas com condições ecológicas diferentes, o que implica em aportes novos, em elementos novos que enriqueciam e mudavam a estrutura primitiva, diríamos, da tradição. Mas, mantendo um núcleo central, um fio condutor" (MARTIN, 2007: 7).
} 
ossos de alguns indivíduos, dentre os quais uma criança com entorno de 18 meses, enterrados de maneira secundária. $O$ mobiliário fúnebre coletado estava presente em 3 casos, todos indivíduos adultos do sexo masculino, e foi composto de apitos de osso, um colar de cervídeo, contas e pingentes (MARTIN, TORRES \& ALVIM, 1995/1996). Os indivíduos que habitaram o sítio utilizaram como suporte para os artefatos líticos o quartzo e o sílex, encontrados no sítio sob a forma de lascas trabalhadas, furadores e de um machado polido. Fora isso, nos trabalhos de 1991, foram coletados 17 fragmentos de cerâmica utilitária (FONTES, 2006) e ossos de animais de pequeno e médio porte, a maior parte roedores e mamíferos marsupiais e em bem menor escala animais como a anta (QUEIROZ E CARDOSO, 1995/1996).

No início dos anos 1980 a equipe do Núcleo de Estudos Arqueológicos da Universidade Federal de Pernambuco escavou um outro sítio arqueológico seridoense, trata-se do sítio Mirador - Parelhas/RN. Ocorrem no Mirador algumas semelhanças em relação ao sítio Pedra dos Alexandre, foram escavados uma série de sepultamentos (a maioria crianças) que em alguns casos apresentaram mobiliário fúnebre composto de colares de contas de osso e de concha, além de restos de fogueira. A datação mais antiga foi também de 9.410 anos antes do presente, mostrando que se trataram de grupos da Pedra do Alexandre e do Mirador foram contemporâneos (LUFT, 1989: 28).

Outro sítio arqueológico pesquisado também no município de Parelhas/RN, foi o Pedra do Chinelo - escavado entre 2001 e 2002. Nesta escavação foram coletados dezenas de lascas de sílex e quartzo hialino trabalhada, dois artefatos em pedra polida e fragmentos de amazonita. Além disso, a principal contribuição do trabalho ficou por conta dos 566 fragmentos de cerâmica coletados. Esta cerâmica é alisada externamente e recebeu decoração incisa, é apontada por VIDAL $(2002,163)$ como passível de ter sido utilizada como urnas funerárias. Em termos de perspectivas culturais, o fato de se ter no mesmo sítio uma datação para ossos de uma mandíbula de um indivíduo adulto de 1.991 anos antes do presente, faz com que está ocorrência de grupos ceramistas seja a primeira para a região.

No ano de 2006 foram feitas prospecções no sítio arqueológico chamado de Casa Santa. Após dividir o sítio em três possíveis áreas de ocupação, as 
escavações procedidas evidenciaram estruturas de fogueira, fragmentos de ocre, lascas de quartzo, quartzito e de silexito. Esta etapa de trabalho legou poucos vestígios arqueológicos, fazendo crer no fato de que este sítio tenha sido usado apenas como um espaço para a elaboração de pinturas rupestres.

A maior parte dos trabalhos arqueológicos sobre a região Seridó dão conta do universo simbólico, são pesquisas feitas sobre os registros rupestres, identificando os tipos de grafismo, a repetição de cenas e outros aspectos. E são de fato as pinturas rupestres que estão no imaginário dos moradores locais, que desde há muito se acostumaram com este tipo de registro. Os materiais coletados nas escavações estão depositados no Laboratório de Arqueologia do Núcleo de Estudos Arqueológicos da Universidade Federal de Pernambuco, a alegação para o depósito desses bens neste laboratório é a de que não instituições que pudessem receber a tutela do material. Não há de fato nenhum laboratório ou núcleo de arqueologia no Seridó norte-rio-grandense, contudo, há duas instituições que poderiam pensadas como lugares para a guarda senão de todo, ao menos de parte deste acervo.

\section{Os museus do Seridó e do Sertanejo e suas coleções arqueológicas.}

O Museu do Seridó foi criado nos anos 1960, mais especificamente em 1966, por iniciativa de um pároco da cidade de Caicó, o Padre Antenor Salvino de Araújo, o primeiro nome desta instituição foi Museu 'Pena de Ouro' e homenageava o fundador da Escola de Latim do Seridó, o Padre Brito Guerra. Este lugar foi pensado inicialmente como um espaço para se apresentar a história da região e, ao mesmo tempo, preservar o pensamento e as artes do povo seridoense. Inicialmente gerenciado pela diocese de Caicó, no início dos anos oitenta este museu passou a ser vinculado à Universidade Federal do Rio Grande do Norte, através do Centro Regional de Ensino Superior do Seridó (CERES).

O Museu do Seridó funciona em um prédio de dois pavimentos construído no século XIX para abrigar o Senado da Câmara e a Cadeia Pública da Vila do Príncipe, a vila que deu origem a hoje cidade de Caicó, e doado pela prefeitura desta cidade em 13 de janeiro de 1973 (figura 39). 


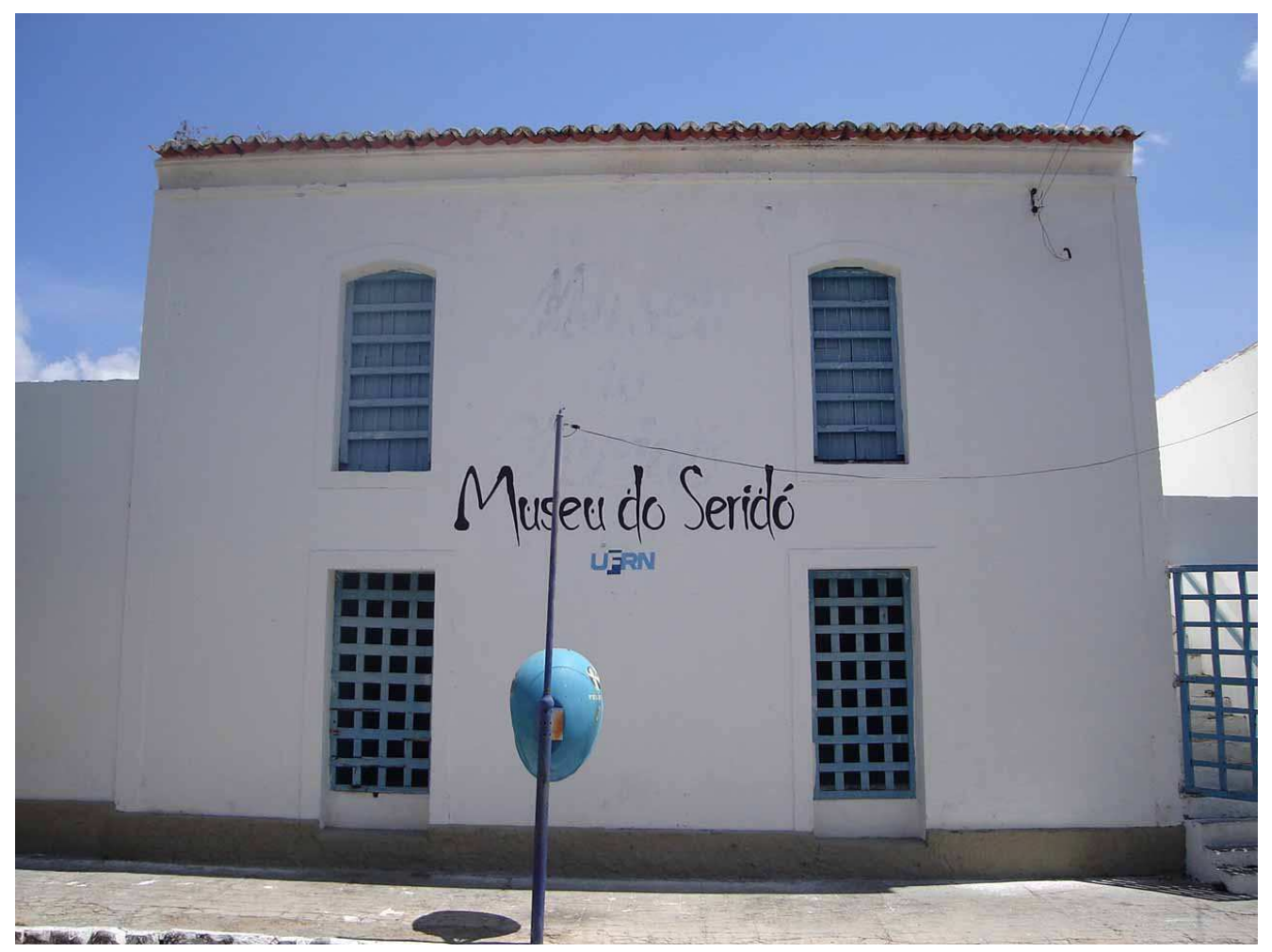

Figura 39. Fachada do prédio onde funciona o Museu do Seridó.

Em 1993 foi feita uma reforma no prédio e um trabalho de reestruturação do acervo e da exposição. Esta reestruturação visava adequar o museu às técnicas museográficas então em voga e torná-lo, um espaço de prática pedagógica, de pesquisa e de relação com a comunidade. Naquela época a temática central escolhida para o museu foi: 'Seridó, Terra Nossa de Cada Dia'. Em derredor desse tema foram criados cinco núcleos expositivos chamados de 'Seridó, terra e homem pré-cabralino', 'Sociedade: produção e trabalho', 'Devoção e arte do Seridó', 'Ofício e arte do Seridó' e 'Indústria alimentícia de subsistência'. Estes núcleos abordavam, respectivamente:

- A fauna e a flora da região Seridó, além de dados relativos à presença indígena na região e a sua herança.

- O homem, a família, o criatório e as atividades econômicas no Seridó.

- A devoção do povo seridoense e a festa dos Negros do Rosário. 
- Um núcleo temático que abordaria profissões outrora muito praticadas na região, como os ofícios de seleiro e de ferreiro.

- Elementos relativos à cozinha regional, como a fabricação da rapadura e a da farinha.

Alguns traços desta época ainda estão presentes hoje, como o espaço dedicado ao engenho de rapadura (figura 40), entretanto, o circuito de exposição foi em parte modificado na passagem dos anos 1990 para os anos 2000. Além disso, desde 2005 o museu vem passando por problemas administrativos que repercutiram tanto na expografia quanto no gerenciamento do acervo. Este acervo foi montado a

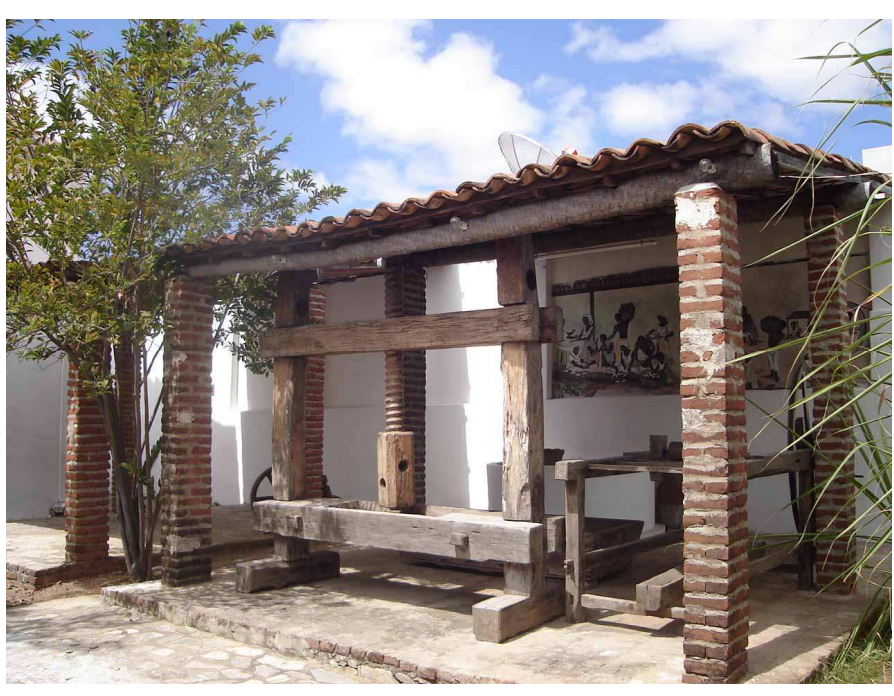

Figura 40. Núcleo remanescente da exposição do início dos anos 1990, réplica de um engenho de rapadura.

partir de doações de famílias e moradores da região do Seridó, sendo composto por objetos de mobiliário, de arte sacra, de artesanato, porcelanas, fotografias e artefatos líticos.

A coleção arqueológica é composta por: cinco lâminas de machado, duas mãos de mó, dois instrumentos passivos - tipo pilão, uma bola de boleadeira, dois núcleos e uma lasca trabalhada (figura 41). As lâminas de machado são polidas e picoteadas, sendo que algumas apresentam protuberâncias laterais, chamadas por Prous et. al. (2002) de orelhas para encabamento, alguns dos gumes são convexos e outros levemente convexos. A matéria-prima predominante é o granito, havendo também duas peças de sílex. Esta coleção arqueológica não é a única em uma instituição museológica na região do Seridó, há outra no Museu do Sertanejo na cidade de Acari/RN. 


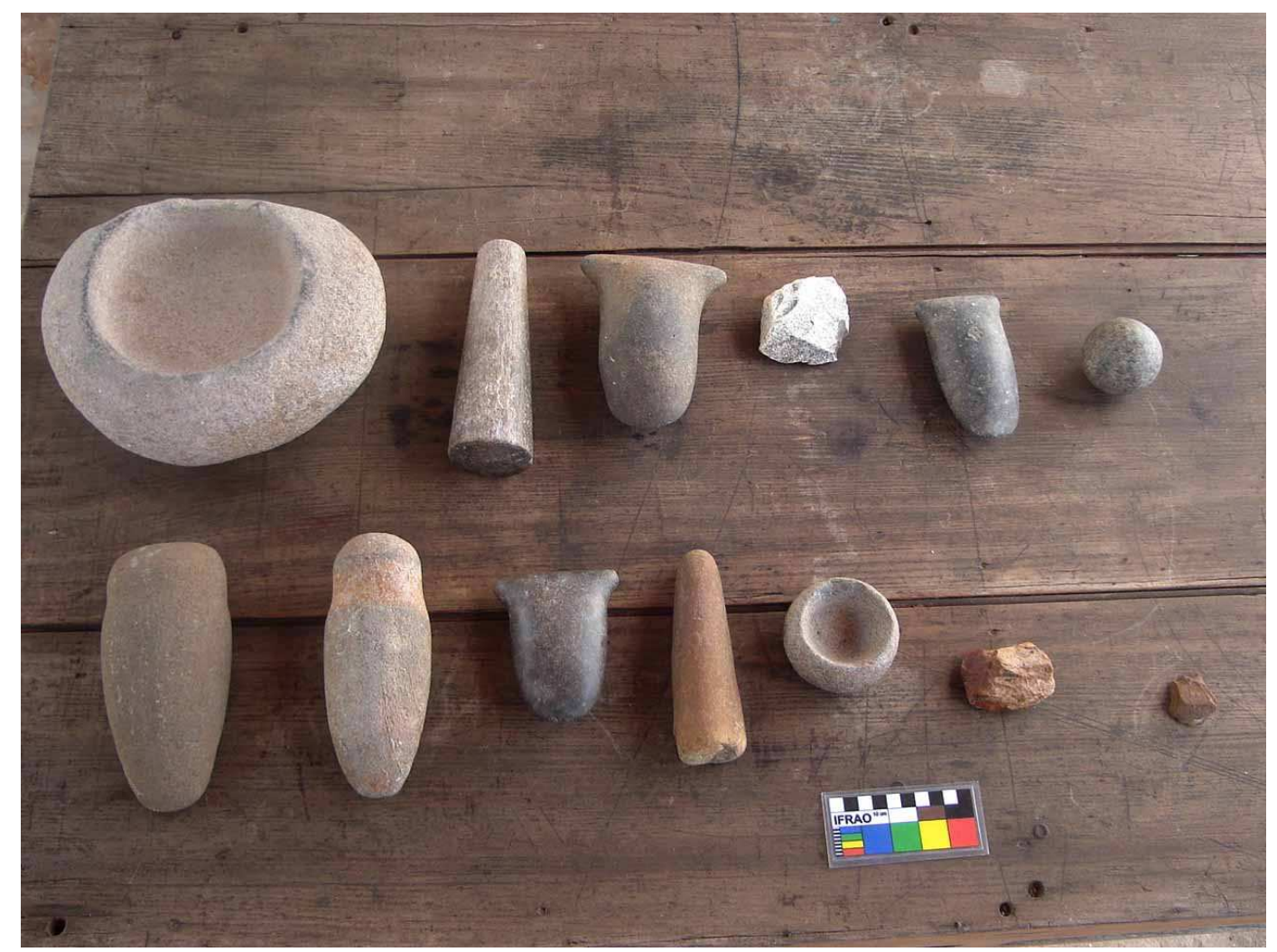

Figura 41. Coleção arqueológica do Museu do Seridó.

O Museu do Sertanejo, também conhecido como Museu Histórico de Acari, foi criado em 1990. Da mesma forma que no caso de Caicó e de Mossoró, este museu funciona em um prédio que no século XIX foi a Casa de Câmara e Cadeia de Acari (figura 42). É um museu municipal e sua última reforma foi no ano de 2004, com recursos advindos do Ministério da Cultura. A exposição deste museu foi elaborada a partir de dois eixos, comuns na vida do sertanejo norte-riograndense, a criação de gado e o cultivo do algodão. A criação de gado foi o vetor do povoamento no interior da Capitania do Rio Grande, a partir das fazendas de criação de gado surgiram vários núcleos de povoação que depois se tornaram cidade. Já o algodão foi o principal produto cultivado no sertão do Rio Grande do Norte no século XX, entretanto, nas últimas décadas deste século começou a entrar em crise devido a problemas nas plantações. Mas, além destas temáticas, a exposição do museu aborda a prática da pesca artesanal no Açude Gargalheiras e 
segundo a coordenadora cultural deste museu (Francinete de Souza) "outras histórias referentes ao cotidiano da cidade e contexto que faz parte de Acari”.

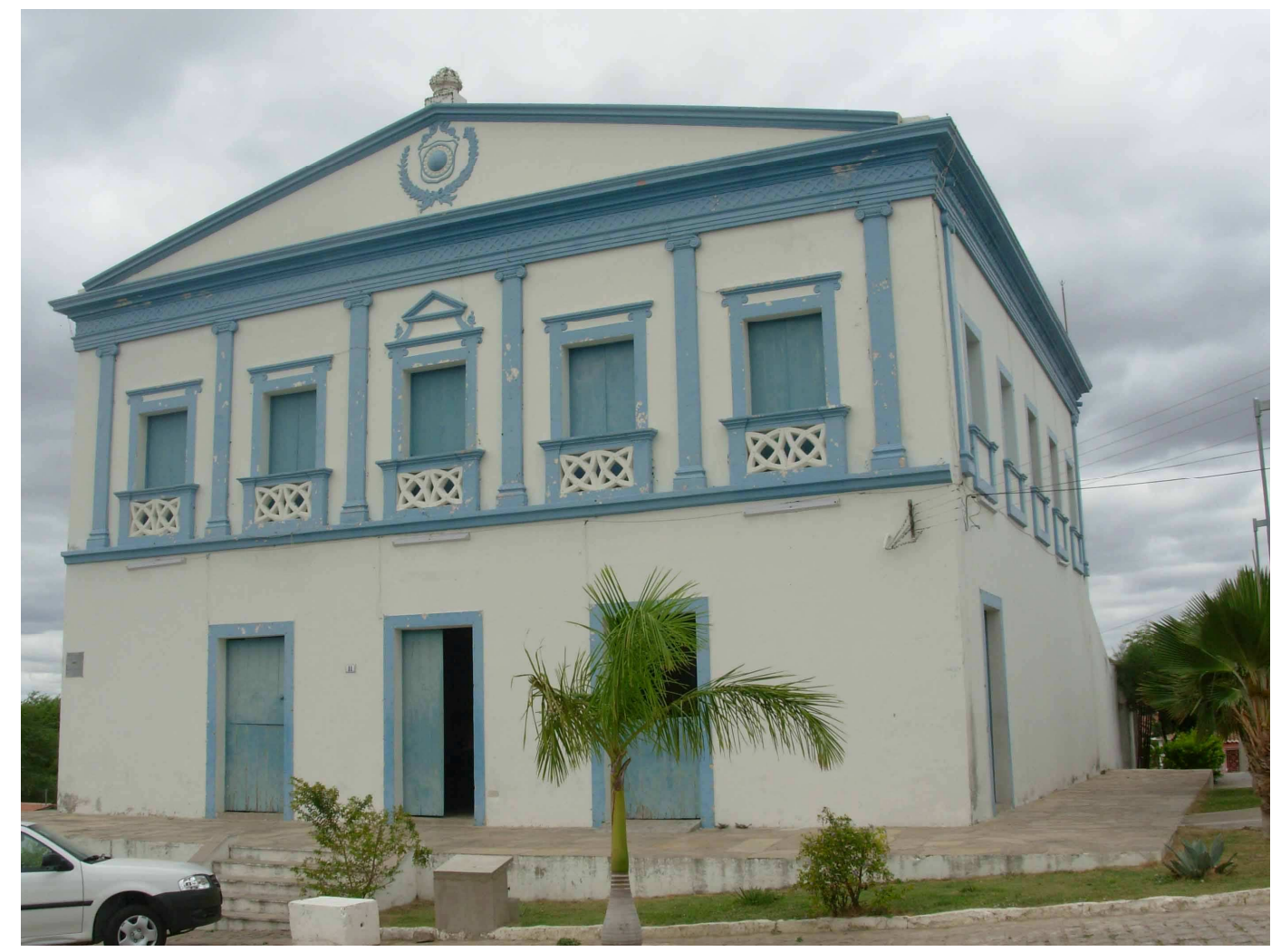

Figura 42. Fachada principal do Museu do Sertanejo.

O museu de Acari tem a peculiaridade de ser dotado de uma interação com a comunidade local, neste espaço acontecem também eventos culturais e oficinas pedagógicas. A exposição foi montada após uma consulta aos moradores da cidade e foram estes também que doaram as peças que compõem o acervo do museu. Este acervo, hoje, é de cerca de duas mil peças e o número de doações ao museu diminuiu devido à temática adotada pela instituição. A exposição montada foi dividida em dois módulos que, seguindo a arquitetura do prédio, foram alocados respectivamente no piso inferior e no primeiro andar. No pavimento superior estão as exposições temporárias e outras que se reportam ao contexto da cidade de Acari, como iconografias das famílias acarienses e a cultura material de antigas fazendas da região, já no piso inferior a exposição aborda as economias tradicionais do 
Seridó, como a criação de gado. Em meio aos objetos relativos à pecuária seridoense está a exposição relativa ao passado pré-colonial da região (figuras 43 e 44).

Figura 43. Exposição de objetos relativos à pecuária seridoense. Abaixo, no canto direito, o início do expositor com peças da coleção arqueológica.

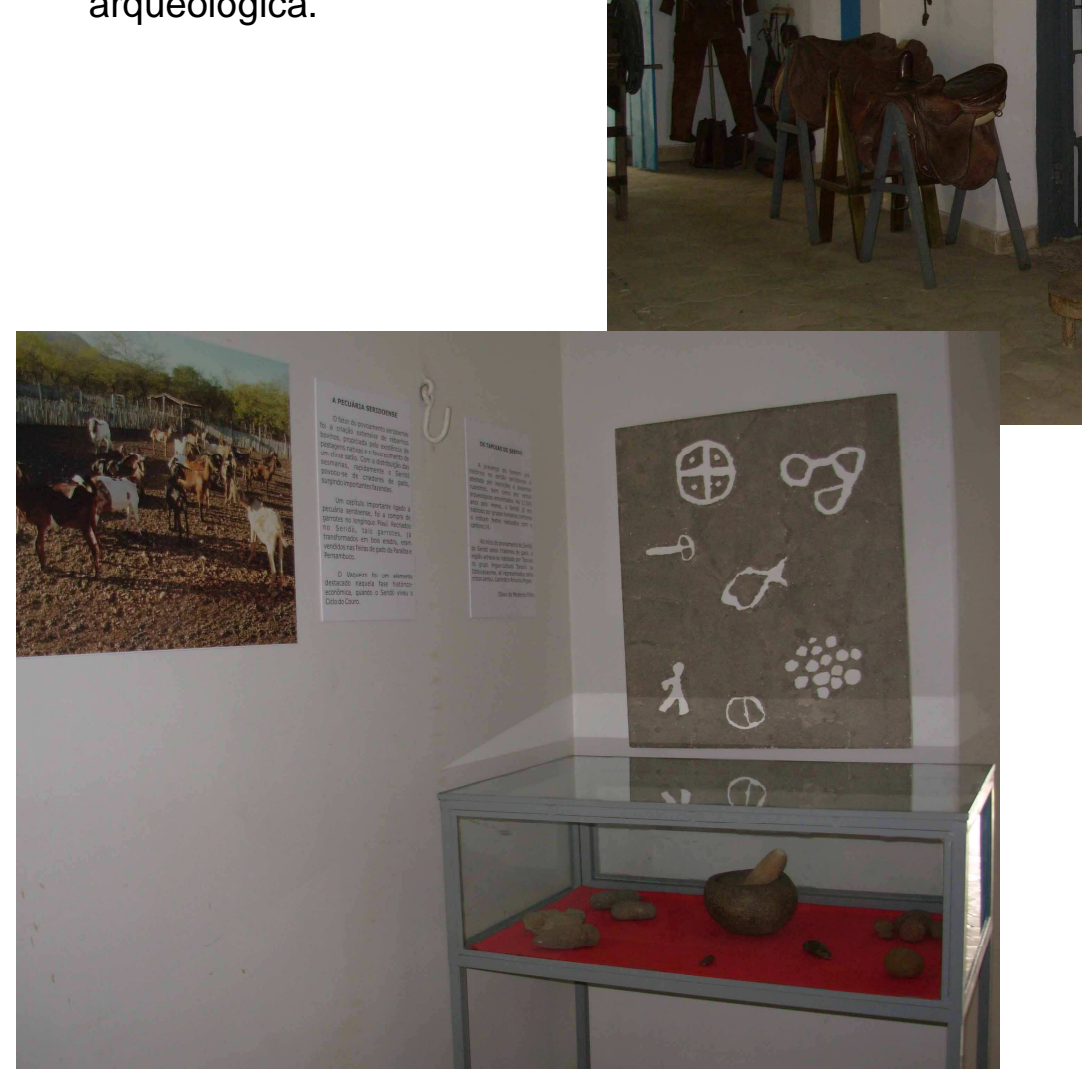

Figura 44. Exposição dos artefatos da coleção arqueológica, com um painel representando pinturas e gravuras da região Seridó. No alto, à esquerda, foto e texto versando a respeito da pecuária seridoense.

A coleção arqueológica do Museu do Sertanejo é formada por duas pontas de projéteis fragmentadas (figura 45), uma mão de pilão, um pilão, um batedor semi-esférico (tipo quebra-coquinho), dois fragmentos de lâmina de machado, duas lâminas de machado fragmentadas (uma na porção distal e outra na porção proximal), 5 blocos de hematita e 1 seixo. A matéria-prima no caso dos artefatos é de dois tipos, o sílex para os artefatos lascados e o granito para os líticos polidos. 


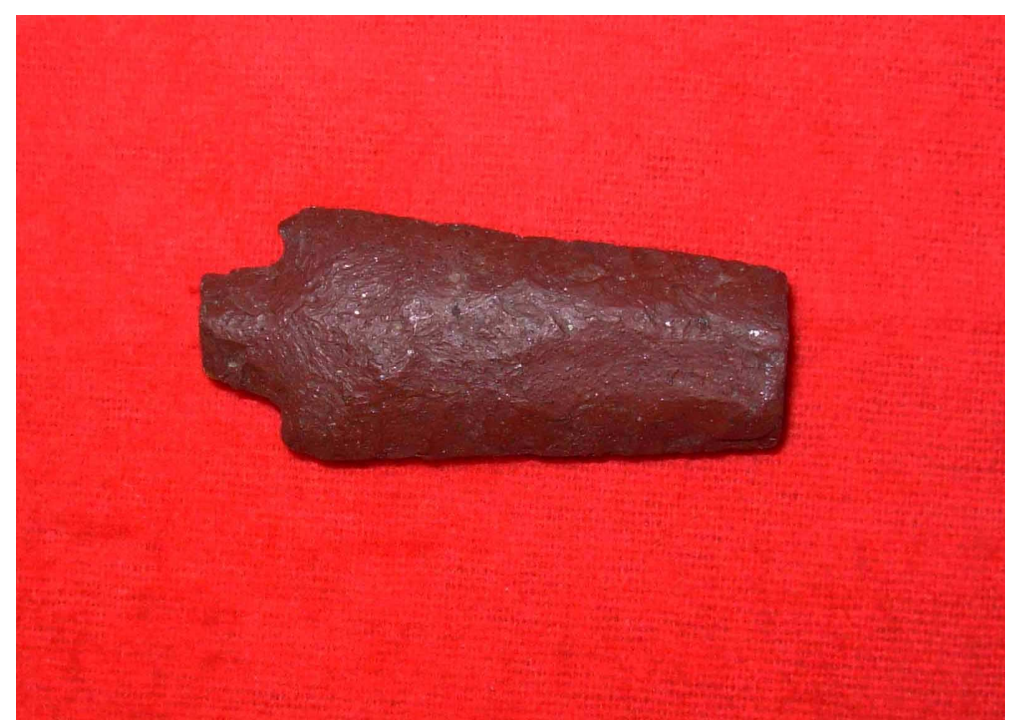

Figura 45. Ponta de projétil fragmentada no pedúnculo e na porção distal. Uma das peças integrantes da coleção arqueológica do Museu do Sertanejo.

O único texto que acompanha a exposição das peças arqueológicas (figura 46) é de autoria de um historiador, autodidata, norte-rio-grandense e além de apresentar uma cronologia equivocada, peca ao quebrar o discurso para se reportar ao povoamento do Seridó pelos criadores de gado, época em que a região era habitada por várias etnias indígenas.

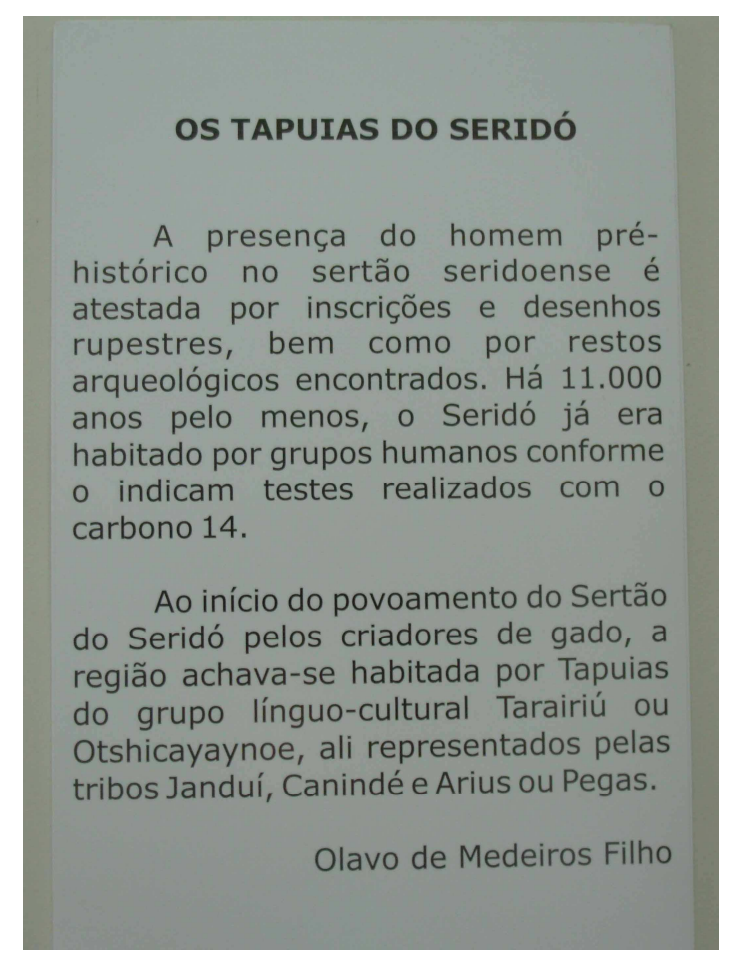

Figura 46. Texto de Olavo de Medeiros Filho que figura na exposição das peças arqueológicas. 
O Museu do Sertanejo possui uma temática que se relaciona com as características sociais e com a historicidade tanto de Acari, quanto do Seridó norterio-grandense. $O$ fato de ser um museu com relativa participação da comunidade local faz com que temáticas mais próximas do cotidiano, como, por exemplo, a introdução do rádio na cidade, não deixem de ser abordadas. Contudo, justamente este caráter popular fez com que não pudesse ficar de fora da exposição a arqueologia, justamente porque sítios arqueológicos são comuns na região e os moradores de Acari, assim como os do Seridó como um todo, há muito convivem com informações sobre "as pinturas de índios" (uma das maneiras como são popularmente referenciadas as pinturas rupestres).

Isto tornou a inserção de elementos pré-coloniais na exposição algo necessário. A necessidade de musealizar as parcas fontes arqueológicas que estão nesta instituição, fez com que elas fossem introduzidas em meio a objetos com os quais não consegue dialogar. As peças arqueológicas formam um quadro exótico em meio a artefatos das lidas diárias dos sertanejos, como esporas e roupas de couro, e o único texto que poderia contribuir para que elas pudessem ser pensadas como referências patrimoniais consegue, mesmo breve, ser repleto de incoerência.

As coleções arqueológicas do Museu do Seridó e do Museu do Sertanejo não podem atuar nem como um lampejo do patrimônio arqueológico que há na região, ou como uma amostra do que já foi coletado em escavações que são procedidas desde a década de 1980, até porque os artefatos que compõem essas coleções chegaram até os museus levados por agricultores ou por moradores da cidade que as encontraram em suas propriedades rurais. Fato é que nenhum dos materiais arqueológicos coletados em escavações na região do Seridó norte-riograndense se encontra em solo potiguar.

Também é um fato, evidenciado nas páginas anteriores, que as instituições museais aqui trabalhadas apresentam além de problemas de gerenciamento, outras perspectivas em termos de sua museografia. Nem no Museu do Sertanejo e nem no Museu do Seridó, a arqueologia é uma prioridade - talvez até não seja algo secundário. Mas é, isto com certeza, algo necessário em uma região repleta de sítios arqueológicos e cuja ocupação humana é até o momento a mais 
antiga do estado. E se os moradores do Seridó não usam termos técnicos ou acadêmicos para se referir aos moradores pré-históricos da região, preferem chamalos genericamente de índios, sabem ao menos com certeza que aquilo faz parte do passado. Um passado seridoense e potiguar como um todo, e neste caso, o que possui a capacidade de mediador com este passado são justamente os bens arqueológicos, tanto os que estão nestes museus, quanto os que estão emigrados em solo pernambucano e que representam o produto de pesquisas arqueológicas, pesquisas como a que foi conduzida no Lajedo de Soledade e que teve seu acervo musealizado no Museu de Soledade.

\section{A pesquisa arqueológica no Lajedo de Soledade e o produto dos trabalhos: 0}

\section{Museu de Soledade.}

Encravado no sertão potiguar, a aproximadamente 420 quilômetros de Natal, o Lajedo de Soledade - Apodi/RN, encontra-se cercado por uma caatinga hiperxerófila onde predominam espécies vegetativas como o faveleiro (Cnidosculos), o xique-xique (Pilocereus) e a macambira (Bromélia Laciniosa), as quais, entre outras, adaptam-se muito bem ao clima semi-árido da região. Além do olho d'água que existe no lajedo, vazio em períodos de seca, as outras fontes de água para esta área estão em um raio de aproximadamente 15 quilômetros, são a lagoa de Apodi e o rio Apodi-Mossoró, que possui uma bacia hidrográfica com por volta de 17.500 $\mathrm{Km}^{2}$ e que justamente por isto é caracterizada, segundo o Diagnóstico Estrutural do Estado de 1976, como a maior bacia genuinamente norte-rio-grandense. Ainda com relação ao lajedo, podemos dizer que:

"Trata-se (...) de um enorme afloramento calcáreo, no qual desponta um grande conjunto de estreitas grutas, galerias longas e baixas, pequenos abrigos sob a rocha e ravinas, causadas pelo movimento das águas nas estações invernosas que erodiram durante as últimas dezenas de milhares de anos as superfícies da Formação Jandaíra. Assim, o trabalho milenar da água sobre o calcáreo, tanto das chuvas quanto do lençol freático, por sua natural irregularidade, propiciou uma infinidade de 'molduras' naturais para pinturas e gravuras das mais diversas formas, tamanhos e técnicas" (ALBUQUERQUE \& PACHECO, 2000: 116). 
Não é de hoje que estas pinturas chamam a atenção dos visitantes que passaram próximo ao lajedo, ou que delas tenham ouvido relatos. Ainda no século XVIII, as pinturas de soledade foram citadas pelo padre jesuíta Francisco Correia Teles de Menezes no tomo IV da sua obra 'Mapa do Novo Descoberto', o tomo IV é intitulado 'Da Lamentação Brasílica'. Este texto traz consigo uma das primeiras informações sobre registros rupestres no Rio Grande do Norte, em meio às quais encontram-se referências à região de Apodi e, mais especificamente, sobre o Lajedo de Soledade. O manuscrito do padre Teles de Menezes foi compilado por Tristão de Alencar Araripe no século XIX, vindo este último trabalho, o de Araripe, a figurar em obras que versam sobre o estado do Rio Grande do Norte e sendo possível, a partir de uma destas, se retirar parte da citação feita pelo jesuíta Teles de Menezes quando escreve sobre Soledade:

"LAJES DA SOLEDADE - êste sítio é da entrada da picada de Apodi para diante uma légua; é dono de uma parte dêle José Lopes, morador nas vargens do Apodi, o qual diz que, quando cavou o ôlho d'água, que é entre pedras, descobriu-o subterrâneamente muitos cacos de telha e de louça, como que com êles se fêz o entupimento, e logo pulsou água em abundância.

Êste poço esta em uma ilharga dum pequeno terreno de terra firme, entre grande lajeiro de pedra de cal, por cujas ribanceiras e locas estão muitos sinais de tinta encarnada; mas como é aposento de passageiros, êstes os tem raspado com facas e ralado com pedras; e que por isto já mal se divulgam" (BASTANI, 1991: 346).

$\mathrm{Na}$ sua época, o padre Teles de Menezes conseguiu apontar duas importantes ocorrências relacionadas aos painéis de pinturas rupestres do Lajedo de Soledade: a necessidade de um trabalho mais acurado com os vestígios presentes no lugar e a também necessária, interrupção da destruição progressiva que estes estavam sofrendo. Estes foram pontos comuns que, em maior ou menor monta, constaram nas observações de cientistas já no século XX, dentre os quais podemos citar Souza Cunha, Vingt-Un Rosado, Elizabeth Cabral, Nássaro Nasser e Tom Miller. Este último tentou levar a cabo no ano de 1981 um projeto de pesquisa na chapada do Apodi, mas, infelizmente, não obteve sucesso e o projeto malogrou diante da burocracia universitária. 
No final da década de 1980, funcionários da Petrobrás e integrantes da comunidade local iniciaram tentativas de educação patrimonial com o intuito de preservar os vestígios que ainda restavam no lajedo, começando, destarte, a plantar as bases do que depois se tornou a FALS - Fundação Amigos do Lajedo de Soledade. Entretanto, desde esta época se fez mister que fossem oferecidas à sociedade local, que até então sobrevivia basicamente da mineração artesanal do calcário, outras fontes de renda através da aplicação na região de formas de desenvolvimento sustentável.

A alternativa viável encontrada naquele momento, para evitar a destruição do sítio, foi preservar apenas as áreas do lajedo que "apresentarem vestígios arqueológicos e paleontológicos, ou feições geológicas dignas de monta" (BAGNOLI, 1993: 6). Foi em meio a este contexto de resgate e preservação dos vestígios presentes no lajedo que surgiu, em 1993, o Projeto Arqueológico Soledade, o qual incluiu, também, estudos nas áreas de geologia, paleontologia e espeleologia.

A formação calcária de Soledade se apresenta durante boa parte do ano com a ausência de água, entretanto, as épocas de chuvas produziram vazantes que levaram consigo vestígios que estavam depositados naquele lajedo e isto, apesar de não ser justificativa, resultou em uma dificuldade de se caracterizar culturalmente os grupos humanos que fizeram uso do Lajedo de Soledade durante o período préhistórico. Mesmo assim, por meio dos vestígios coletados, foi possível retirar informações que serviram de lastro a uma idéia de utilização recorrente do lajedo, mas não como espaço de habitação e sim, como lugar cerimonial das sociedades ágrafas do entorno, pois, "ainda que a ocorrência fosse dez vezes maior, ou seja, ainda que tivessem sido encontrados apenas $10 \%$ do material que teria sido utilizado nas proximidades do lajedo, ainda assim seria pouco" (ALBUQUERQUE \& PACHECO, 2000: 121).

Em meio ao material lítico encontrado durante as escavações arqueológicas, foi possível atentar para a presença mais acentuada do quartzo como matéria-prima utilizada na fabricação de instrumentos, sendo esta uma característica, de maneira geral, das "indústrias líticas mais recentes, entre 6.000 e 
2.500 A.P. (antes do presente), as quais no Nordeste brasileiro estão associadas, primordialmente, aos grupos da tradição Agreste de pinturas rupestres" (SOUZA, PACHECO \& SPENCER, 1994: 6). Os vestígios cerâmicos encontrados foram poucos, porém com alguns traços básicos que indicam, pelo formato dos fragmentos, tratar-se de pequenas vasilhas utilizadas como recipientes para bebidas ou tintas, além do que demonstram diversificados tipos de decoração.

As pesquisas arqueológicas indicaram a presença de remanescentes vestigiais de grupos que não dependiam da caça, sendo, provavelmente, grupos coletores/agricultores os que habitaram as vizinhanças do lajedo. Embora o uso da cerâmica não implique, necessariamente, na prática da agricultura, a associação feita à presença em Soledade de grupos coletores/agricultores ganha uma maior ênfase quando se enxerga que os grupos humanos pré-históricos moradores do sítio do Góes, próximo ao sítio arqueológico do Lajedo de Soledade, além de trabalharem o material lítico sob a forma de objetos polidos, enfaticamente os machados usados por comunidades indígenas para o desmatamento de áreas objetivando o plantio -, também eram ceramistas, autores de "uma cerâmica grosseira, mal cosida, com grande quantidade de grânulos" (SILVA, 1983: 82).

Como não foram coletadas amostras para datações radiocarbônicas durante as escavações, a ocupação humana no sito arqueológico do Lajedo de Soledade foi inserida no contexto das teorias sobre o povoamento do Nordeste brasileiro, que consideram, pelo menos parcialmente, os ambientes das regiões onde os conjuntos arqueológicos encontram-se inseridos, as temperaturas causticantes do clima semi-árido, a vegetação do tipo caatinga e os recursos disponibilizados por este ambiente, de modo que se pensa em ocupações humanas neste lugar desde pelo menos 5.000 anos antes do presente.

Se a presença humana em Soledade tem cerca de 5.000 anos, o mesmo não pode ser dito do sítio arqueológico em si, uma formação calcária com a idade estimada em 90 milhões de anos. E é justamente isto que está presente no Museu de Soledade, a história do sítio arqueológico.

O Museu de Soledade foi criado em 1993 e possui o formato de uma caieira (figura 47). Ele surgiu como parte de um projeto de incentivo ao 
desenvolvimento sustentável levado adiante pela estatal brasileira Petrobrás. Esta empresa começou o trabalho com moradores da região no ano de 1990, até então a maioria dos moradores do Distrito de Soledade vivia do trabalho nas caeiras, os fornos de fabricação da cal e, para a subsistência, depredavam constantemente o sítio arqueológico para a extração deste mineral.

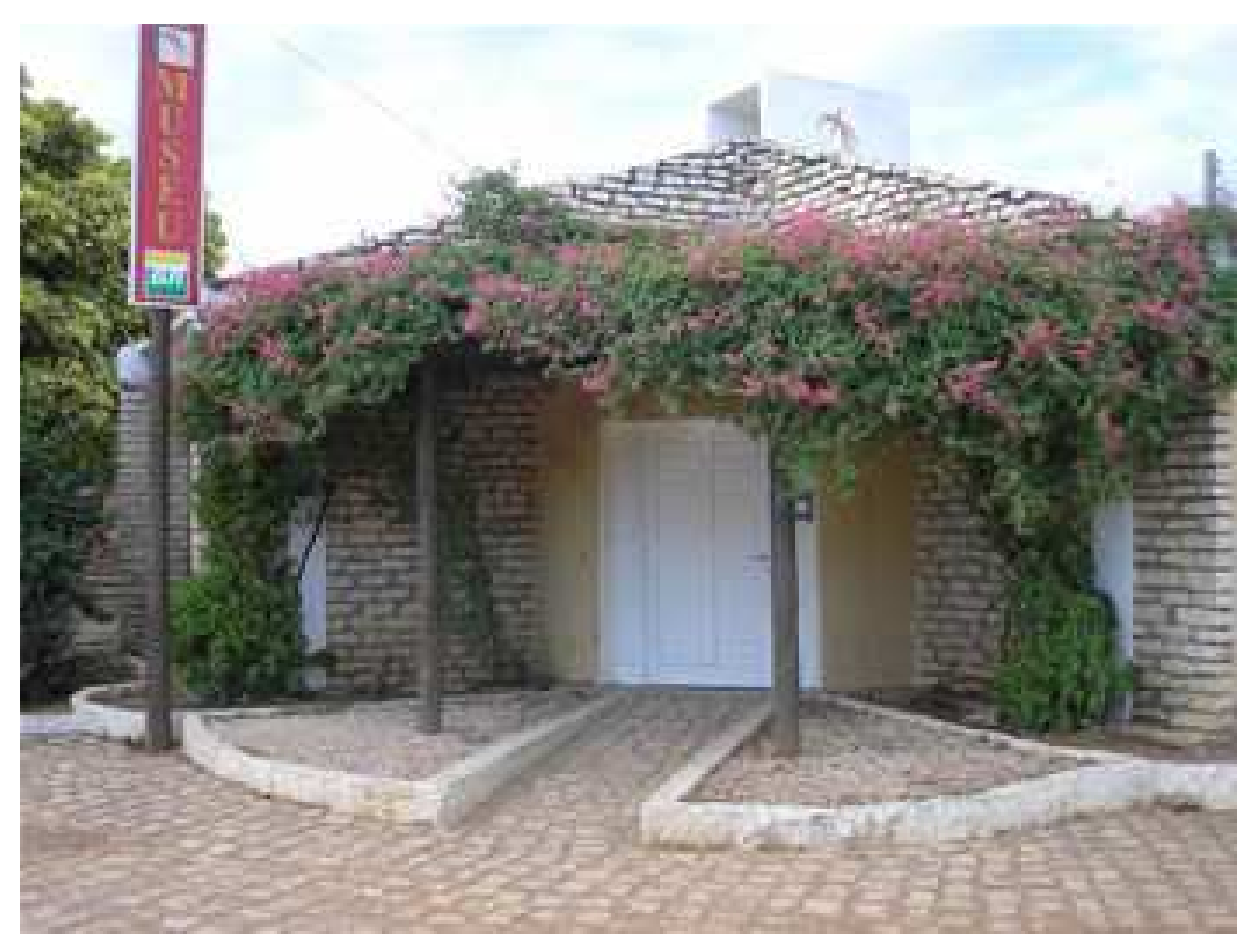

Figura 47. Fachada atual do Museu de Soledade.

Além da construção do museu, foram delimitadas três áreas do lajedo que hoje funcionam como roteiros para os turistas. Acessos foram feitos para facilitar a caminhada dos visitantes por entre as formações calcárias (figura 48), de modo que o museu e a visita ao sítio arqueológico formam roteiros complementares. Os guias no passeio pelo sítio e os que ficam no museu são todos da localidade e receberam um treinamento específico para desempenhar esta função tendo, inclusive, alguns deles participado como auxiliares de escavação no projeto de 1993, além disso, apresentam como peculiaridade o fato de serem vários deles filhos de extrabalhadores que retiravam o sustento da fabricação da cal. Outro aspecto também 
a ser ressaltado, é que o sustento que antes provinha da cal hoje é obtido no CAL (Centro de Atividades Artesanais), lugar onde são vendidas peças de cerâmica, cestaria, pinturas com temáticas locais e artigos de papel reciclado.

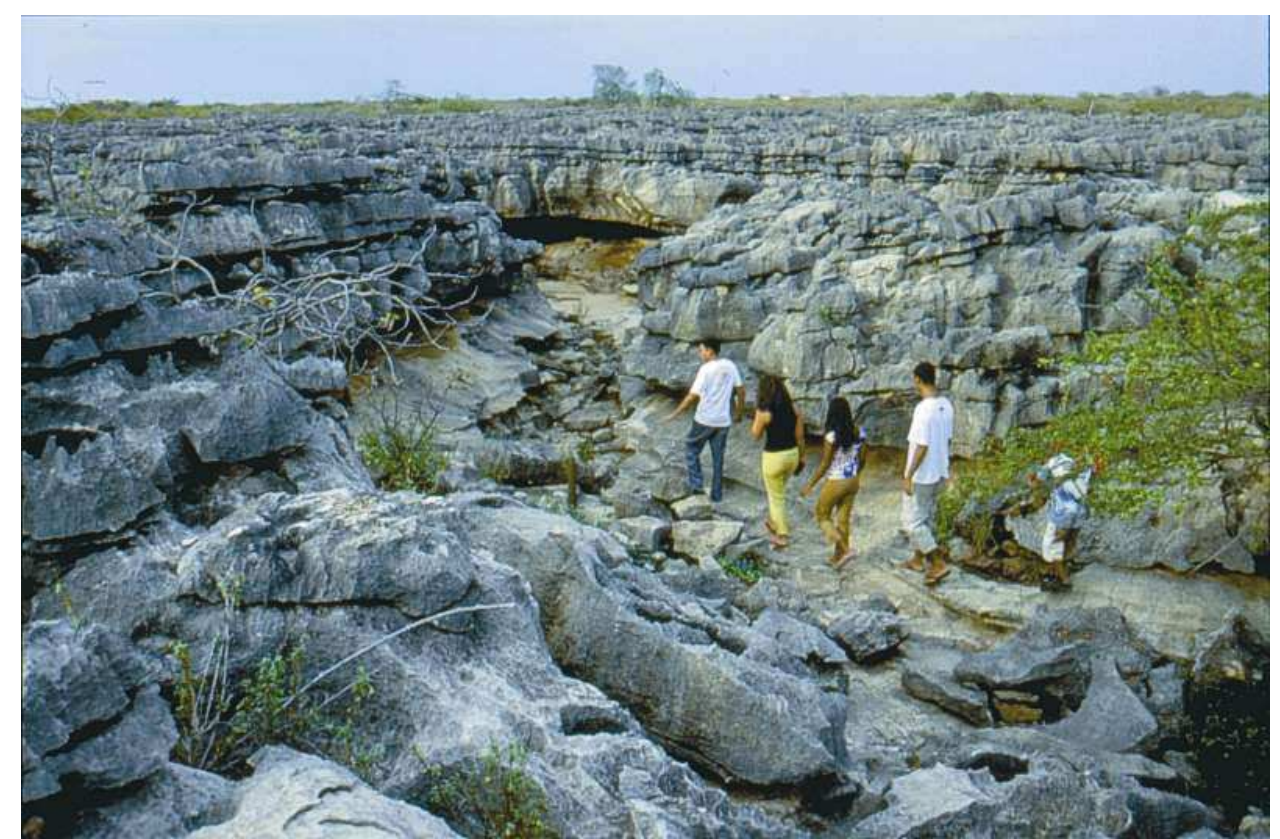

Figura 48. Um dos guias do sítio arqueológico Lajedo de Soledade acompanhando turistas em sua visitação.

O fato de ter sido construído no formato de uma caieira, que tem a geometria parecida com a de um pentágono, contribuiu para que em seu interior a exposição dos acervos fosse feita de maneira semicircular (figura 49), com os objetos postos em vitrines junto às paredes e também, em expositores colocados no vão central (figura 50). O visitante segue uma espécie de linha do tempo onde ela parte da formação

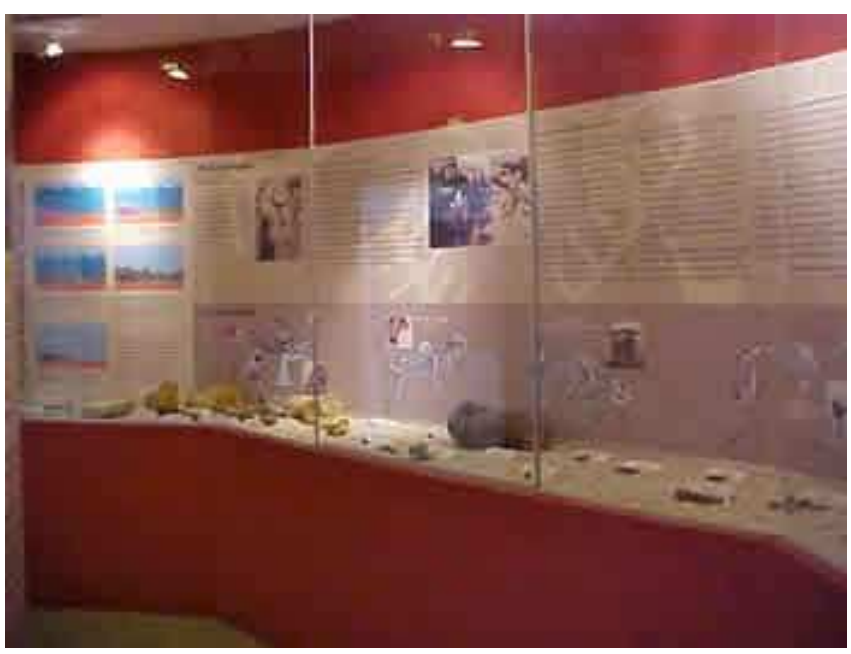

Figura 49. Trecho da exposição dedicado ao registro fóssil encontrado em escavações paleontológicas no Lajedo de Soledade. 
geológica do sítio até os artefatos culturais coletados durante as escavações, no caminho ele passa também pela fauna que ocupou a região antes da presença do homem. Além de painéis explicativos, que acompanham a exposição tanto das evidências paleontológicas quanto das arqueológicas e ilustrações que complementam a apresentação temática.

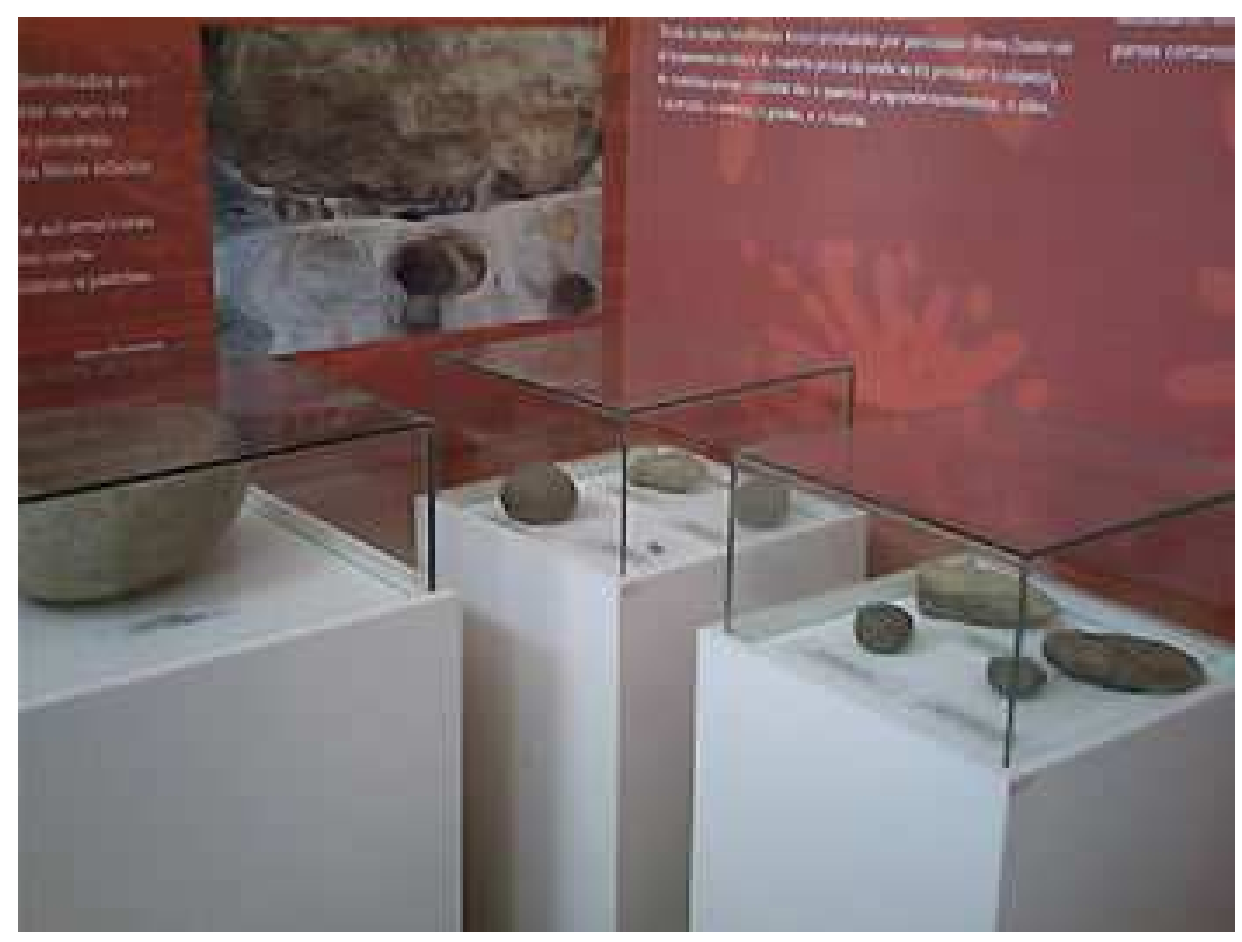

Figura 50. Expositores onde figuram artefatos líticos e cerâmicos exposição do Museu do Lajedo de Soledade.

Valho-me agora de um caso que ocorreu durante as escavações arqueológicas no Lajedo de Soledade e que foi contado a mim, tanto por um dos membros da equipe de arqueologia quanto por um dos guias do sítio arqueológico Lajedo de Soledade, para que possamos entender um pouco da situação de relação para com o patrimônio arqueológico que conseguiu ser estabelecida na localidade onde existe o sítio.

Um dos painéis de registro rupestre mais famoso em Soledade se chama Painel das Araras e é composto, entre outras imagens, por duas figuras zoomorfas que se assemelham, como não podia deixar de ser, a araras. Durante as escavações, um morador local resolveu durante a noite raspar parte de uma dessas 
figuras zoomorfas. No dia seguinte a equipe de arqueologia percebeu o que havia acontecido e comunicou às lideranças da comunidade, logo, todos os moradores do lugar ficaram sabendo da situação e se demonstraram tão indignados que o cidadão que depredou o painel retornou lá em uma outra noite para 'preencher' com tinta óleo o espaço que havia ficado 'vago' na imagem e fez isto, por medo de ser espancado.

O Sítio e as estruturas que foram criadas próximas a ele representam hoje uma herança para a comunidade local, e o fato de ser herança no caso de Soledade ocorre devido a dois aspectos: primeiro, porque o trabalho exercido na área fez com que os moradores adquirissem referências de pertencimento em relação ao sítio arqueológico e, em segundo lugar, é herança porque não é só dos que moram lá hoje, é dos que irão morar lá no futuro. No caso do Museu de Soledade temos um espaço onde elementos da Arqueologia e da Museologia se misturaram e da complementaridade surgiu um espaço onde as fontes arqueológicas não estão desarticuladas, nem exiladas e onde as pessoas a elas se sentem vinculadas é, pois, o melhor exemplo de Musealização da Arqueologia observado em solo potiguar. 
CONSIDERAÇÕES FINAIS. 
Os temas e os problemas tratados nesta dissertação merecem ser retomados, isto tendo em vista que as análises procedidas possam ser aqui referendadas. Por isso, iniciamos nossa retomada a partir do capítulo 1 (Coleções, museus e identidades: elementos de uma relação entre patrimônio e arqueologia). Neste capítulo, ao abordarmos o exotismo dos gabinetes de curiosidades o fizemos para situá-lo em um contexto precedente ao surgimento das instituições museológicas. Isto foi necessário para entendermos estes espaços não só como um lugar para guardar as coisas do mundo desconhecido, mas também para perceber que no bojo da dimensão enciclopédica dos gabinetes podem ser enxergadas práticas de seriação e classificação dos objetos que representam uma forma de ordenamento racional e, também, uma etapa a mais no processo que ocasionou o rompimento com a cultura da curiosidade e o aparecimento de espaços dotados de características físicas, ambientais, jurídicas e com uma função mais pública do que privada. Além disso, os museus se tornaram já no século XIX não somente um espaço de visualização do passado, mas essencialmente um lugar para as pesquisas científicas.

A bem da verdade, os museus no século XIX atuaram como instituições onde o exercício da pesquisa era praticado de uma maneira mais voltada para as ciências naturais. Contudo, ao largo de ciências como a Botânica e a Zoologia tomaram corpo áreas do conhecimento como a Arqueologia e a Antropologia e que, no século $X X$ ganharam o status de ciência. Neste contexto de implantação de ciências recentes e de valorização das ciências naturais é que se estabeleceram em solo brasileiro as primeiras instituições museológicas, representadas nesta pesquisa pelo Museu Nacional, o Museu Paraense Emílio Goeldi e o Museu Paulista.

Estas instituições criadas no século $X I X$ cruzaram todo o século $X X$ e chegaram ao século XXI com os seus perfis parcialmente mantidos. O Museu Nacional mantém um caráter plural (cosmopolita e em certa medida enciclopédico) e conserva boa parte dos acervos formados entre os séculos XIX e XX; o Museu Paraense Emílio Goeldi continua sendo uma instituição que visa favorecer o desenvolvimento da região Norte do Brasil através de pesquisas científicas em vários campos, dentre os quais figura o do conhecimento arqueológico; o Museu 
Paulista teve seu perfil alterado e de um espaço que visava por em relevo todo o avanço científico e cultural da região Sudeste do país, particularmente de São Paulo, hoje é um museu apenas de caráter histórico.

Entretanto, nesta pesquisa e especificamente no primeiro capítulo, a inserção de aspectos relativos aos primeiros museus brasileiros ocorreu como forma de esboçar um quadro sucinto em que ficasse clara a relação destas instituições com os auspícios da Arqueologia brasileira, situando o leitor em meio ao contexto em que ocorreu a formação das primeiras coleções arqueológicas e, também, contribuindo para a percepção de algumas práticas relacionadas à Musealização da Arqueologia que podem ser pensadas como um elemento de ligação entre essas instituições e as outras analisadas nesta dissertação. Isto porque, o escopo de atuação desta dissertação se situa no âmbito da Musealização da Arqueologia em instituições norte-rio-grandenses.

Isto posto, ficou claro que não poderíamos falar sobre a Musealização da Arqueologia no Rio Grande do Norte, sem antes explicar que tal linha de pesquisa lida não só com a comunicação do conhecimento arqueológico, mas também com o estudo das relações estabelecidas para com o patrimônio arqueológico no âmbito de instituições museológicas. A partir do diálogo entre a Arqueologia e a Museologia se buscou o entendimento das conjunturas que permeiam as relações estabelecidas para com as fontes pré-coloniais em solo potiguar. Assim foi evidenciado o fato de que, onde e também quando, essas fontes não são convertidas em referência cultural, ocorre a formação de conjunturas em que se configura a estratigrafia do abandono. Isto é, surgem situações em meio às quais o patrimônio arqueológico fica isolado e sem se articular com outros conjuntos patrimoniais, ou seja, não proporciona informações e não contribui para a formação das identidades.

Temos então nestas circunstâncias dois aspectos conceituais que se destacam e que possuem relação com a temática abordada nesta dissertação e, por isso, foram escolhidos para encerrar o primeiro capítulo, tais aspectos são justamente a idéia de patrimônio, principalmente a idéia de patrimônio arqueológico, e a relação que envolve este patrimônio, sob uma forma chamada genericamente de cultura material, e a formação das identidades no Nordeste do Brasil. Na 
conformação destas identidades coube uma grande parcela à produção historiográfica e a organismos específicos desta produção, como, por exemplo, os Institutos Históricos e Geográficos. Nestes lugares, em particular no Nordeste do Brasil, observou-se o papel de destaque ocupado pela cultura material.

Foi percebido que os objetos atuaram como divisores de água entre os grupos majoritários na formação das identidades local e regional e os grupos que margearam este processo, em meio aos quais figuram com grande ênfase as sociedades indígenas. A resultante desse processo, em alguns casos, foi a reprodução destes padrões nos museus criados na região Nordeste, os quais possuíram como base teórica para suas exposições a produção histórica nacional e, principalmente, local.

Estas são características que se ligam diretamente ao quadro estabelecido a partir da análise feita no âmbito do Museu Histórico Lauro da Escóssia e que se faz presente no segundo capítulo (Museu Histórico Lauro da Escóssia: estratos de uma coleção arqueológica no Oeste potiguar). Essa é uma instituição de caráter municipal e foi construída como parte de um projeto político e cultural que visava abranger não só a cidade de Mossoró, mas também os outros municípios da região Oeste do estado. Neste caso, uma vinculação com o poder público municipal trouxe menos conseqüências benéficas e mais implicações negativas, como, por exemplo, as várias mudanças de espaço físico que contribuíram para uma diminuição substancial do acervo - isto até o museu ser alocado no prédio da antiga Casa de Câmara e Cadeia de Mossoró -, ou a reforma infindável iniciada no início dos anos 2000 e que até o momento não foi concluída.

A conjuntura observada no Museu Histórico Lauro da Escóssia possibilitou a identificação de uma maior preocupação com a história local, valorizando acontecimentos como a abolição da escravidão em Mossoró, a resistência ao bando de um cangaceiro chamado Lampeão e o primeiro voto feminino. A tendência de valorizar estas ocorrências em detrimento de outras é, podemos dizer, um padrão local, isto tendo em vista o fato de que a administração pública municipal valoriza estes aspectos através de iniciativas como, por exemplo, a promoção de eventos culturais e a denominação de logradouros públicos, isto 
forma um quadro de desenvolvimento sócio-histórico em que a formação das identidades dos mossoroenses fica associada apenas a estes acontecimentos.

A principal conseqüência enxergada por nós a partir desta conjuntura é que a coleção arqueológica, formada por aquisições que ocorrem desde a criação do museu no final da década de 1940, se encontra isolada, empoeirada e desvalorizada por não fazer parte do quadro identitário mossoroense e, também, por estar vinculada a um passado pré-colonial norte-rio-grandense - um passado que é, conforme observado nas leituras sobre as sínteses historiográficas do Rio Grande do Norte, frequentemente relegado ao esquecimento.

A coleção arqueológica estudada detalhadamente no capítulo 2 é formada por artefatos e fragmentos de artefatos cerâmicos e líticos. Entre estes últimos há tanto peças lascadas quanto polidas e, também, picoteadas. Sendo que a maior parte são líticos polidos, mais precisamente, lâminas de machado. Além destas, a coleção é formada por pontas de projéteis, contas de colar, um raspador planoconvexo e um tembetá. Os objetos de cerâmica são todos cachimbos, mais precisamente fornilhos de cachimbo que possuem características de uma cerâmica de contato, podendo ser que se tratem de cachimbos caboclos.

Esses artefatos ingressaram no MHLE apenas de duas formas, a compra e a doação - havendo casos em que a peça foi comprada por um cidadão que logo em seguida fez a doação ao museu. Estas formas de aquisição implicaram no fato de que o material se encontra descontextualizado e com limitadas possibilidades de uso científico. Entretanto, um trabalho de curadoria técnica pode, além da elementar classificação das peças, situá-las em meio aos estudos arqueológicos já feitos no estado, havendo casos em que os artefatos provêm de áreas já estudadas, ou situações em que estes objetos apontam para o potencial arqueológico de algumas regiões que até o momento não foram alvo de trabalhos arqueológicos mais sistemáticos.

A abordagem desta coleção no Museu Histórico Lauro da Escóssia, devido às características estruturais deste e, também, devido ao corpo de funcionários presentes na instituição, ocorre de uma maneira a não possibilitar o entendimento sobre as fontes do passado pré-colonial da região Oeste e, de uma 
maneira mais ampla, do Rio Grande do Norte. O direcionamento desta instituição para uma história local que favoreça a divulgação identitária pretendida pelo poder público municipal e, consubstanciada por uma historiografia local de abordagem tradicional, fez com que as fontes arqueológicas ficassem restritas às prateleiras, fechadas em sacos plásticos ou expostas ao tempo, mas, em ambos os casos, cobertas por camadas de pó e, por conseqüência, abandonadas.

Esta situação é diametralmente oposta a que foi observada no Museu Câmara Cascudo, tema do terceiro capítulo desta dissertação (Arqueografia dos estudos em pré-história e arqueologia e a transposição expográfica destes estudos). Esta instituição se configura teoricamente tanto como um espaço para a extroversão do conhecimento, quanto como um lugar de produção do saber. Esse museu é vinculado à Universidade Federal do Rio Grande do Norte e foi criado em 1961, quando então se chamava Instituto de Antropologia, com o objetivo de ser um espaço de pesquisa e que favorecesse o desenvolvimento de algumas ciências que estavam sendo academicamente implantadas no estado naquele momento, por exemplo, a Antropologia e a Geologia. A situação analisada no Museu Câmara Cascudo é diferente por dois motivos básicos: 1) Esta instituição possui desde a sua criação um setor dedicado à pesquisa arqueológica; 2) A produção de conhecimento na área de arqueologia refletiu em um modo diferente de tratamento para com as fontes pré-coloniais, embora tal característica não signifique a ausência de elementos relativos à estratigrafia do abandono.

A pesquisa arqueológica desenvolvida no âmbito do Museu Câmara Cascudo alterna três fases distintas, as quais foram intermediadas por dois períodos de diminuição nas atividades. A primeira fase é dominada pela atuação do arqueólogo Nássaro Nasser, coordenador no Rio Grande do Norte dos trabalhos relativos ao Programa Nacional de Pesquisas Arqueológicas (PRONAPA). Esta época corresponde genericamente aos anos de 1965 a 1970, um momento em que as principais pesquisas foram dedicadas ao estudo de dois tipos cerâmicos diagnosticados na foz do sistema Curimataú-Cunhaú e nas imediações da lagoa de Guaraíras, respectivamente, as fases Curimataú (ligada a Tradição Tupiguarani) e Papeba (uma cerâmica de feitio regional). 
No final da década de 1970 ocorre uma ampliação das pesquisas, que haviam diminuído bastante em relação ao ritmo adotado na segunda metade da década anterior e, desta vez, o destaque fica por conta da pluralidade das pesquisas desenvolvidas e do número de arqueólogos. Este período vai desde 1979 até por volta de 1988, neste momento ocorre um deslocamento no eixo das pesquisas que passam a ocorrer também nas regiões central e oeste do estado. Além de sítios cerâmicos, foram estudados também sítios líticos, realizados trabalhos de salvamento arqueológico e executado um curso de Especialização em Arqueologia Pré-Histórica. A partir da ampliação do número de pesquisas e principalmente de pesquisadores - o Museu Câmara Cascudo chegou a ter nesta época seis arqueólogos trabalhando na instituição -, não demorou a causar problemas de convivência interdepartamentais. Assim, o que marca o final dos anos 1980 são os problemas internos no Departamento de Arqueologia do Museu Câmara Cascudo e a implicação que estes trouxeram ao desenvolvimento das pesquisas arqueológicas no Rio Grande do Norte.

A década de 1990 foi um período de pouca atividade no setor de Arqueologia desta instituição e a que se considerar, também neste caso, o fato de que o quadro de profissionais decaiu substancialmente, chegando no final desta década a ter apenas um pesquisador no Departamento de Arqueologia. Com o surgimento dos anos 2000 , a publicação de artigos e alguns trabalhos desenvolvidos sob a forma de diagnósticos e projetos de salvamento arqueológico indicam a fase mais recente da pesquisa arqueológica no Museu Câmara Cascudo. O destaque neste caso fica por conta dos trabalhos de Arqueologia por contrato desenvolvidos em parceria com empresas privadas. Estes trabalhos produziram dados sobre as regiões noroeste e central do estado e, também, implicaram em um aumento substancial no acervo de Arqueologia do museu.

Este acervo é formado por aquisições de várias partes do Rio Grande do Norte, entretanto, a julgar pelas impressões advindas do estudo dos livros de tombo do Departamento de Arqueologia, o registro, bem como o gerenciamento das peças, foi mal conduzido desde a formação das primeiras coleções. Somando-se a estes casos as dificuldades de relacionamento entre os pesquisadores desta instituição, 
ocorreu a formação de um quadro que resultou em expressivas perdas nas informações e também significou a ausência de peças que outrora integraram o acervo do Museu Câmara Cascudo.

Essas peças poderiam hoje perfilar em meio à exposição permanente deste museu. Aliás, esta exposição quando foi caracterizada no final do capítulo 3 evidenciou situações como, por exemplo, o favorecimento de determinados departamentos, como o de Geologia, na composição dos cenários. Isto ocorre, principalmente, pelo fato de que elementos da expografia criada ainda nos anos setenta persistem e figuram de maneira a se contrapor às salas criadas nas décadas de 1990 e 2000.

A expografia outrora de vanguarda, sofreu intervenções principalmente nas últimas duas décadas e ocasionou a formação de uma conjuntura que desfavorece os elementos relativos às fontes arqueológicas. Os bens pré-coloniais estão isolados ou agrupados em um espaço, onde não comunicam ou informam praticamente nada sobre a Pré-história ou a Arqueologia norte-rio-grandense e, não obstante tal situação, apesar da existência de um pretenso texto informativo, este não é de autoria de nenhum pesquisador, ou ex-pesquisador, do setor de Arqueologia do Museu Câmara Cascudo. Tal ocorrência é como se uma instituição de pesquisa renegasse ao esquecimento, além dos artefatos arqueológicos, também os dados produzidos sob sua alçada institucional. Destarte, observamos que as fontes arqueológicas seguiram no Museu Câmara Cascudo caminhos diferentes, mas que implicaram também em abandono e exílio.

Abandono e exílio também são características observadas no Seridó norte-rio-grandense e foram, junto com a realidade observada na formação do Museu de Soledade, o tema do capítulo 4 (Da Fundação Amigos do Lajedo de Soledade ao museu universitário: outros aspectos da Musealização da Arqueologia no Rio Grande do Norte). No caso do Seridó, foi identificada uma contraposição que diz respeito, por um lado, à quantidade de pesquisas desenvolvidas e, por outro, à existência de duas instituições museológicas nas cidades de Acari e Caicó dotadas de coleções arqueológicas, que foram formadas através da doação de peças por parte de moradores desta região. 
A região Seridó, mais especificamente a meso-região do Seridó Oriental, é pesquisada desde a década de 1980 por arqueólogos vinculados ao Núcleo de Estudos Arqueológicos da Universidade Federal de Pernambuco - NEA/UFPE. O foco principal destes estudos são os registros rupestres da chamada sub-tradição seridó, que ocorre no vale do rio Seridó e de seus principais afluentes: o Acauã e o Carnaúba. As escavações arqueológicas procedidas ocorreram nos municípios de Parelhas e Carnaúba dos Dantas e, nestes trabalhos, foram coletados materiais cerâmicos, líticos, vestígios zooarqueológicos, contas de colar e mais de três dezenas de sepultamentos. Este acervo se encontra no Laboratório de Arqueologia do NEA/UFPE. Destas pesquisas resulta uma ampla gama de trabalhos acadêmicos, desde artigos em periódicos, até teses e dissertações, o que compõe uma fonte essencial para o conhecimento da pré-história do Rio Grande do Norte.

Os museus do Seridó e do Sertanejo, respectivamente, em Caicó e Acari funcionam nos prédios que foram as casas de câmara e cadeia destes municípios no tempo em que ainda eram vilas. Ambos também possuem preferência pela valorização da vida do sertanejo seridoense, refletindo uma abordagem sócioeconômica no tratamento e extroversão de seus acervos. Somadas as coleções arqueológicas destas instituições computam 28 peças, incluindo aí alguns blocos de hematita e um seixo. Os artefatos, ou fragmentos destes, são todos líticos (lascados e polidos) e, no caso do Museu do Sertanejo, manifestam a peculiaridade de serem expostos em meio aos elementos que caracterizam a pecuária seridoense.

Isto reflete um quadro de isolamento e desarticulação das fontes précoloniais, quadro complementado neste caso por um texto que de uma maneira anacrônica tenta vincular esses vestígios ao contexto da implantação das fazendas de gado no Seridó. O mesmo Seridó que está repleto de referências acerca da ocupação humana em tempos pré-coloniais e que possui, em municípios como o de Carnaúba dos Dantas, as pinturas rupestres como principal alvo da exploração turística e elemento de conhecimento comum dos moradores, que a elas fazem referência como sendo 'pinturas de índios'.

De um lado temos poucos e desarticulados acervos arqueológicos em um contexto museal, do outro temos uma grande quantidade de informações e coleções 
arqueológicas emigradas para outro espaço institucional. Os museus seridoenses analisados evidenciaram dificuldades administrativas e financeiras e, também, manifestam uma necessidade de apresentar em seu espaço uma maior articulação com as realidades arqueológicas desta região do estado. Atualmente há mecanismos de financiamento por parte de agências do governo, tanto federal quanto estadual, que podem dar cabo ou ao menos minimizar as dificuldades enxergadas, por outro lado, um caminho para superar a necessidade observada carece, além da presença de pessoas capacitadas para gerenciar e comunicar o conhecimento arqueológico produzido, de um retorno ao Rio Grande do Norte dos bens arqueológicos coletados e já estudados. Assim sendo, acreditamos que as realidades observadas são passíveis de modificação, tendo em vista contribuir de uma maneira mais decisiva para a formação das identidades locais e, por conseqüência, para um melhor tratamento no que diz respeito à lida com o patrimônio arqueológico neste rincão do solo potiguar.

Este melhor tratamento seria algo semelhante ao que ocorre no município de Apodi, mais especificamente, no distrito de Soledade e que figura como a última das discussões abordadas no texto desta dissertação. Neste município na região Oeste do estado há um importante sítio arqueológico, chamado Lajedo de Soledade, que foi escavado nos anos 1990 e teve o resultado das pesquisas convertido em um processo de extroversão que torna possível um entendimento não só do sítio arqueológico, mas também do contexto da pré-história norte-rio-grandense.

O Museu de Soledade é parte de um circuito que envolve também o sítio arqueológico e outros espaços para geração de emprego e renda. A Musealização da Arqueologia neste caso contribuiu não só para um maior entendimento da comunidade local do que são os registros arqueológicos presentes neste sítio, como também tornou possível para as pessoas compreender esses bens como algo que faz parte de suas referências, referências que os ligam tanto ao passado quanto ao presente na medida em que auxiliam no seu sustento. $O$ conhecimento está aliado à preservação e os dois juntos puderam retirar do exílio as fontes pré-coloniais e trazê-las para o cenário histórico e cultural do povo que habita o distrito de Soledade e dos que por lá transitam, quando em visitação. 
Concluir, ao invés de concluir prefiro considerar, considerar os aspectos relativos à Musealização da Arqueologia apresentados neste trabalho e que, por estarem no fim desta dissertação, tornar-se-ão minhas considerações finais. Nossa abordagem partiu de uma premissa básica, a de que a Musealização da Arqueologia no Rio Grande do Norte apresenta como principal característica o abandono das fontes arqueológicas e este fato, por conseqüência, ocasionou o exílio destas em meio a outros conjuntos patrimoniais que com elas não dialogam. Entendemos 0 caráter comunicacional das evidências pré-coloniais e associamos este caráter à potencialidade de tornar o patrimônio arqueológico uma referência para a formação das identidades, referências que podem, por exemplo, serem mais bem percebidas por meio de uma ampliação da noção de pertencimento. Não por acaso fechamos nosso trabalho com uma abordagem sobre o Museu de Soledade e isto, sem dúvida nenhuma, nos ajudou a entender que a preservação garante um futuro para o nosso passado. 
FONTES. 
ATA da Reunião da Congregação de Professores do Instituto de Antropologia da Universidade Federal do Rio Grande do Norte, 05/05/1965.

ATA da Reunião da Congregação de Professores do Instituto de Antropologia da Universidade Federal do Rio Grande do Norte, julho de 1970.

ATA da Reunião da Congregação de Professores do Museu Câmara Cascudo da Universidade Federal do Rio Grande do Norte, setembro de 1970.

ATA da Reunião Extraordinária da Congregação de Professores do Instituto de Antropologia da Universidade Federal do Rio Grande do Norte, 05/10/1973.

ATA de Fundação do Instituto de Antropologia da Universidade do Rio Grande do Norte, 19/12/1961.

CARTA de Goiânia: Posição dos arqueólogos brasileiros frente à política do Patrimônio Arqueológico Nacional. Goiânia: IGPA/Universidade Católica de Goiás/SAB, 1985.

CARTA do professor Gaston Laroche para a professora Marlúcia Santiago, de 04 de janeiro de 1989.

CASTRO, Jorge de; LIMA, Roberto Costa. Museu Municipal de Mossoró resiste ao desinteresse de administradores. In: Tribuna do Norte, 31 de outubro de 1979.

DEPARTAMENTO de Arqueologia. Inventário de coleções arqueológicas. Museu Câmara Cascudo: 2006 - 2007.

DIÁRIO de Natal. DN Educação: Museus do RN. n. 1: Seridó. 26 de fevereiro de 2006.

DIÁRIO de Natal. DN Educação: Museus do RN. n. 2: Natal e interior. 30 de abril de 2006.

LAROCHE, Armand François Gaston. Relatório das pesquisas realizadas referentes ao estudo dos grupos pré-históricos pertencentes à Tradição 
Potiguar. Mossoró: Fundação Guimarães Duque, 1987. Série B, n. 379. (Coleção Mossoroense).

LIVRO de Tombo do material coletado para o Setor de Arqueologia do Museu Câmara Cascudo. 2 volumes.

MACEDO, Helder Alexandre Medeiros de. Relatório de Pesquisa do Monumenta Arqueológica - Diagnóstico dos Sítios Arqueológicos de Carnaúba dos Dantas. Caicó: CERES/UFRN, 2004.

MAIA, Geraldo. O Paço Municipal. In: O Mossoroense, Nossa História, 07 de abril de 2004.

O MOSSOROENSE, Caderno Cotidiano, 05 de fevereiro de 2002.

O MOSSOROENSE, Caderno Cultura, 31 de março de 1949.

OFíCIO № 01, de 02 de outubro de 1984 - Do professor Gaston Laroche para o Diretor do Museu Câmara Cascudo, professor Veríssimo Pinheiro de Melo.

OFÍ́CIO ํㅜ 02, de 05 de outubro de 1984 - Do professor Gaston Laroche para o Diretor do Museu Câmara Cascudo, professor Veríssimo Pinheiro de Melo.

OFÍ́CIO no 11/98, de 03 de agosto de 1998 - Do professor Luiz Dutra de Sousa Neto para o Diretor do Museu Câmara Cascudo, professor Jerônimo Rafael de Medeiros.

OLIVEIRA, Izamar Azevedo de; AZEVEDO, Juliana Rocha de. Relatório de Estudo do Acervo Arqueológico em Exposição Permanente e Reserva Técnica. Museu Câmara Cascudo: Departamento de Museologia, fevereiro de 2000.

ROBRAHN-GONZÁLES, Érika M. et. al. Linha de Distribuição 69 KV - Governador Dix-Sept Rosado/Riacho da Forquilha, Rio Grande do Norte. Relatório Final. Documento: Antropologia e Arqueologia, Apoio Institucional: Museu Câmara Cascudo. Julho/2004. 
ROBRAHN-GONZÁLES, Érika M. et. al. Programa de Prospecção e Resgate do Patrimônio Arqueológico: Linha de Distribuição 138 KV - Assú/Guamaré, Rio Grande do Norte. Relatório Final. Documento: Antropologia e Arqueologia, Apoio Institucional: Museu Câmara Cascudo. Junho/2004.

ROBRAHN-GONZÁLES, Érika M. et. al. Programa de Prospecção e Resgate Arqueológico LD Assú/Guamaré, Circuito 2, Rio Grande do Norte. Relatório Final. Documento: Antropologia e Arqueologia, Apoio Institucional: Museu Câmara Cascudo. Julho/2005.

ROLIM, Isaura Éster Fernandes Rosado. Bibliografia sobre o Museu Municipal de Mossoró. In: O Mossoroense, 13 de março de 1994.

RÚSSIO, Waldisa. Museologia e Museu. In: Folha de São Paulo, Suplemento Cultural: 01 de julho de 1979.

SANTOS, Nilo. Museu de Mossoró espera um lugar definitivo para guardar a memória. In: Diário de Natal, DN hoje - 2º Caderno, 09/02/1980.

SOUZA, Paulo Tadeu de, PACHECO, Leila Serafim, SPENCER, Walner Barros. Projeto Soledade: relatório final, 1994.

TASSONE, Vicente Giancotte; MILLER JR., Tom O. Projeto de Salvamento Arqueológico do Baixo Açu: represa engenheiro Armando Gonçalves. Natal: UFRN: Museu Câmara Cascudo, 1980. 
BIBLIOGRAFIA. 
ABUD, Kátia. Currículos de história e políticas públicas: os programas de história do Brasil na escola secundária. In: BITTENCOURT, Circe (Org.). O saber histórico na sala de aula. ed. 7. São Paulo: Contexto, 2002.

ALBUQUERQUE, Paulo Tadeu de Souza, PACHECO, Leila Maria Serafim. O lajedo de soledade: um estudo interpretativo. In: TENÓRIO, Maria Cristina. (Org.). Préhistória da Terra Brasilis. Rio de Janeiro: EDUFRJ, 2000.

ALÇADA, Margarida. Documentar para preservar. In: Práxis ARCHAEOLOGICA. n. 2. Lisboa: Associação Profissional de Arqueólogos, 2007.

ALMEIDA, Adriana Mortara, VASCONCELLOS, Camilo de Mello. Por que visitar museus. In: BITTENCOURT, Circe (Org.). O saber histórico na sala de aula. ed. 7. São Paulo: Contexto, 2002.

ALVES, Márcia A.. Estudo técnico em cerâmica do Brasil. In: Revista do Museu de Arqueologia e Etnologia da USP. n. 4. São Paulo: EDUSP, 1994.

ALVIM, Marília C. de M.. Osteobiografia da população pré-histórica do abrigo Pedra do Alexandre, Carnaúba dos Dantas, RN. In: Clio - Série Arqueológica. n. 11. v. 1. Recife: EDUFPE, 1995-1996.

ARAUJO, Marcelo Mattos; BRUNO, Maria Cristina Oliveira (Orgs.). A memória do pensamento museológico contemporâneo: Documentos e Depoimentos. Comitê Brasileiro do ICOM, 1995.

ARIÉS, Philippe. A história das mentalidades. In: LE GOFF, Jacques. A História Nova. 4. ed. São Paulo: Martins Fontes, 1988.

BAGNOLI, E.. O lajedo de soledade, Apodi - RN: um exemplo de preservação do patrimônio cultural brasileiro. Revista da SAB. v. 8. n. 1. São Paulo: SAB, 1994.

O lajedo de soledade, Apodi (RN) - um exemplo de preservação do patrimônio cultural brasileiro com patrocínio da Petrobrás. In: Anais do 4 seminário ambiental do sistema Petrobrás. v. 2. Contagem - MG: Petrobrás, nov. 1993. 
BANN, Stephen. As invenções da história: ensaios sobre a representação do passado. São Paulo: EDUNESP, 1994.

BARCELOS NETO, A.. Coleções etnográficas do Alto Xingu: 1884 - 1998. In: Revista do Museu de Arqueologia e Etnologia. n. 9. São Paulo: EDUSP, 1999.

BARRETO, Cristina. A construção de um passado pré-colonial: uma breve história da arqueologia no Brasil. In: Revista USP. n. 44. São Paulo: EDUSP, dezembro/fevereiro, 1999-2000.

BASTANI, Tanus Jorge. Minas e Minérios no Brasil: tesouros, cidades préhistóricas e minas abandonadas. Série B, n. 999, 1991. (Coleção Mossoroense).

BITTENCOURT, Circe. Livros didáticos entre textos e imagens. In: BITTENCOURT, Circe (Org.). O saber histórico na sala de aula. ed. 7. São Paulo: Contexto, 2002.

BITTENCOURT, José Neves. Museu Paraense Emílio Goeldi: uma instituição científica em um museu. In: MUSAS. n. 2. Brasília: IPHAN, 2006.

BORGES, F. M.. Prospecção de Sítios Arqueológicos no Sertão do Seridó Carnaúba dos Dantas (RN): Sítio Furna dos Caboclos. In: Anais do IV Congresso de Iniciação Científica - CONIC. Recife: EDUFPE, 1996. p. 454.

BREFE, Ana Claudia Fonseca. O Museu Paulista: Affonso de Taunay e a memória nacional, 1917 - 1945. São Paulo: EDUNESP, 2005.

Os primórdios do museu: da elaboração conceitual à instituição pública. In: Proj. Hístória. São Paulo, nov., 1998. p. 281-315.

BRITO, Paula Sônia. O Museu do Seridó: a história que se faz presente. In: http://www.cerescaico.ufrn.br/museu/historico.htm - acessado em 23/01/2008.

BRUNO, Maria Cristina Oliveira. A trajetória do Museu do Índio como fonte para a investigação da inserção social do desenvolvimento e construção do conhecimento nas disciplinas de Arqueologia e Antropologia. In: Artigos/Arqueologia, História, Estratégia. Campinas: Núcleo de Estudos Estratégicos/UNICAMP, 1999. 
Musealização da Arqueologia: um estudo de modelos para o Projeto Paranapanema. Tese de Doutorado. São Paulo: Programa de Pós-Graduação Interdepartamental em Arqueologia, Faculdade de Filosofia, Letras e Ciências Humanas - Universidade de São Paulo/USP, 1995.

A importância de processos museológicos para a preservação do patrimônio. In: Revista do Museu de Arqueologia e Etnologia. Suplemento 3. São Paulo: EDUSP, 1999b.

Arqueologia e antropofagia: a musealização de sítios arqueológicos. In: Revista do Patrimônio Histórico e Artístico Nacional: Museus: antropofagia da memória e do patrimônio. n. 31. Brasília: IPHAN, 2005.

. Musealização da arqueologia: um estudo de modelos para o Projeto Paranapanema. In: Cadernos de sociomuseologia. n. 17. Lisboa: Universidade Lusófona de Humanidades e Tecnologias, 1999a.

Museus de arqueologia: uma história de conquistadores, abandonos e mudanças. In: Revista do Museu de Arqueologia e Etnologia. n. 6. São Paulo: EDUSP, 1996.

Principais campos da ação museológica. Seminário CCBB: Museus e exposições no século XXI: vetores e desafios contemporâneos. Julho de 2004.

BRUNO, Maria Cristina Oliveira; GUEDES, Sandra P. L. de Camargo; AFONSO, Marisa Coutinho; ALVEZ, Maria Cristina. Um olhar museológico para a Arqueologia: a exposição "Pré-História Regional" de Joinville (Santa Catarina). In: Revista de Museu de Arqueologia e Etnologia. n. 1. São Paulo: EDUSP, 1991.

CABRAL, Elizabeth Mafra; NASSER, Nássaro A. Souza. Informação sobre inscrições rupestres no Rio Grande do Norte. Natal: UFRN, 1983. Série B, n. 384. (Coleção Mossoroense). 
CALI, Plácido. Políticas municipais de gestão do patrimônio arqueológico. Tese de Doutorado. São Paulo: Programa de Pós-Graduação em Arqueologia, Museu de Arqueologia e Etnologia - Universidade de São Paulo/USP, 2005.

CÂNDIDO, Manuelina Maria Duarte. Arqueologia musealizada - Patrimônio cultural e preservação em Fernando de Noronha. Dissertação de Mestrado. São Paulo: Programa de Pós-Graduação em Arqueologia, Faculdade de Filosofia, Letras e Ciências Humanas - Universidade de São Paulo/USP, 2004.

CARVALHO, José Nunes Cabral de. Considerações sobre a fauna pleistocênica do Lajedo da Escada. Mossoró: Fundação Guimarães Duque, 1983. Série B, n. 387. (Coleção Mossoroense).

CARVALHO, José Nunes Cabral de; et al. Informações sobre a jazida fossilífera pleistocênica do Lajedo da Escada, município de Mossoró, Rio Grande do Norte. Mossoró: Fundação Guimarães Duque, 1983. Série B, n. 389. (Coleção Mossoroense).

CARVALHO, José Nunes Cabral de; SILVA, Antonio Campos e; OLIVEIRA, Leon Diniz Dantas de; VASCONCELOS, Manoel Daylor Teixeira de. Relatório preliminar das investigações geopaleontológicas na área fossilífera pleistocênica da fazenda Lagea Formosa, município de São Rafael. Mossoró: Fundação Guimarães Duque, 1983. Série B, n. 333. (Coleção Mossoroense).

CASCUDO, Luís da Câmara. História do Rio Grande do Norte. 2. ed. Rio de Janeiro: Achiamé, Natal: FJA, 1986.

COSTA, Diogo Menezes. Arqueologia patrimonial: o pensar do construir. In: Habitus. v. 2. Goiânia, 2004.

COSTA, Ivanilda Pinheiro da. A Antropologia no Museu 'Câmara Cascudo'. In: Anais da II Reunião de Antropólogos do Norte e do Nordeste. Recife: UFPE; Brasília: CNPq; Rio de Janeiro: FINEP/ABA, 1991. 
DE BLASIS, Paulo A. D.. Indicadores da transição do arcaico para o formativo na região montanhosa do médio vale do Ribeira. In: TENÓRIO, Maria Cristina (Org.). Pré-história da Terra Brasilis. Rio de Janeiro: EDUFRJ, 2000.

DIAGNÓSTICO Estrutural do Estado: recursos naturais. v. 2. Natal: Fundação Instituto de Desenvolvimento do Rio Grande do Norte - IDEC, 1976.

ENDERE, Maria Luz. Arqueologia y legislación em Argentina: cómo proteger el patrimonio arqueológico. Buenos Aires: INCUAPA/UNC, 2000.

FONTES, Mauro Alexandre Farias. A Cerâmica Pré-Histórica da Área Arqueológica do Seridó/RN. Dissertação de Mestrado. Recife: Programa de PósGraduação em História, Centro de Filosofia e Ciências Humanas - Universidade Federal de Pernambuco/UFPE, 2003.

- O perfil cerâmico cotidiano e cerimonial dos sítios arqueológicos da Pedra do Alexander, Casa de Pedra e Pedra do Chinelo - RN. In: Clio - Série Arqueológica. n. 21. v. 1. Recife: EDUFPE, 2006.

FUNARI, Pedro Paulo Abreu. A cultura material e a construção da mitologia bandeirante: problemas da identidade nacional brasileira. In: IDÉIAS. Campinas: UNICAMP, n. 2, jan/jun, 1995.

FUNARI, Pedro Paulo; PELEGRINI, Sandra C. A.. Patrimônio histórico e cultural. Rio de Janeiro: ZAHAR, 2006. (Coleção Passo-a-passo).

FUNARI, Pedro Paulo; FERREIRA, Lúcio Menezes. Cultura Material Histórica e Patrimônio. Primeira Versão. n. 120. Campinas: UNICAMP, abril de 2003.

GAY, Peter. Caçadores e coletores. In: GAY, Peter. Guerras do Prazer. A experiência burguesa: da Rainha Vitória a Freud. v. 5. São Paulo: Companhia das Letras, 2001.

GOLDMEIER, Valter Augusto. Geomorfologia de alguns sítios pré-históricos do Seridó (RN). In: Clio - Série Arqueológica. n.5. Recife: EDUFPE, 1989. 
GOMES, Denise Maria Cavalcante. Cerâmica Arqueológica da Amazônia: vasilhas da coleção tapajônica MAE - USP. São Paulo: EDUSP: FAPESP: Imprensa Oficial do Estado de São Paulo, 2002.

GUIMARÃES, Carlos Magno. Uma coleção de vestígios da cultura Konduri. In: Arquivos do Museu de História Natural da UFMG. v. 10. Belo Horizonte: UFMG, 1985.

JORGE, Vítor Oliveira. Arqueologia, património e cultura. Lisboa: ED. Instituto Piaget, 2000.

LAMARTINE, Oswaldo. Algumas peças líticas do Museu Municipal de Mossoró. Mossoró: Fundação Guimarães Duque, 1982. Série B. n. 378. (Coleção Mossoroense).

LAMING-EMPERAIRE, Annette. Guia para o estudo das indústrias líticas da América do Sul. Curitiba: EDUFPR, 1967.

LAROCHE, Armand François Gaston. Algumas contribuições para o estudo do povoamento do nordeste do Brasil, a partir de $\mathbf{1 1 . 0 0 0}$ anos BP, histórico - da Tradição Itaparica etc. ed. 3. Mossoró: Fundação Guimarães Duque, 2003. Série B, n. 2302. (Coleção Mossoroense).

Algumas informações sobre as pesquisas arqueológicas no nordeste do Brasil. Suplemento. n. 2. Natal: UFRN, 1980.

Alguns aspectos da arqueologia nordestina. Suplemento. n. 13. Natal: UFRN, 1983.

Ambiente e ecossistema da pré-história do Nordeste brasileiro. CLIO. n. 4. Recife: EDUFPE, 1981.

Arqueologia do Baixo Açu e notícias sobre culturas líticas do Rio Grande do Norte. Suplemento. n. 7. Natal: UFRN, 1981. 
Contribuições por datações do $\mathrm{C} 14$ as pesquisas arqueológicas nordestinas - (Pernambuco e Rio Grande do Norte até 1980). Suplemento. n. 5. Natal: UFRN, 1980.

- Ensaios morfológicos sobre tecnologias líticas nordestinas desde 11.000 anos AP. Mossoró: Fundação Guimarães Duque, 1984. Série B, n. 422. (Coleção Mossoroense).

- Notas preliminares sobre o sítio pré-histórico da Casa de Pedra: município de Martins - RN. Mossoró: Fundação Guimarães Duque, 1988. Série A, n. 28. (Coleção Mossoroense).

- Tópicos básicos de esclarecimentos resumidos referentes aos caçadores nômades do nordeste, em tempos finais do pleistoceno e começo do holoceno. Arquivos do Museu de História Natural da UFMG. v. VI - VII. Belo Horizonte: UFMG, 1981 - 1982.

LAROCHE, Armand François Gaston; LAROCHE, Adjelma Soares e Silva. O sítio arqueológico de Mangueiros - Macaíba/RN. Recife: Editora Massangana/Fundação Joaquim Nabuco, 1982.

LAROCHE, Armand François Gaston; LAROCHE, Adjelma Soares e Silva. As técnicas líticas da Fase Martins - Casa de Pedra de Martins/RN. Mossoró: Fundação Guimarães Duque, 1992. Série C, n. 793. (Coleção Mossoroense).

LAROCHE, Gaston Armand François; LAROCHE, Adjelma Soares e Silva. Ensaios de classificação tipológica sobre as pontas de arremessos e outros objetos líticos da tradição Potiguar. Suplemento. n. 15. Natal: UFRN, 1983.

LEMOS, Carlos A. C.. O que é patrimônio histórico. 5. ed. São Paulo: Brasiliense, 2004. (Coleção Primeiros Passos).

LOPES, Maria Margaret. O Brasil descobre a pesquisa científica: os museus e as ciências naturais no século XIX. São Paulo: Hucitec, 1995. 
LUFT, Vladmir José. Os restos alimentares do sítio Mirador no Boqueirão de Parelhas - RN. In: Clio - Série Arqueológica. n.5. Recife: EDUFPE, 1989.

LUNA, Suely. O sítio Sinal Verde - São Lourenço da Mata, PE. Uma aldeia préhistórica na zona da mata pernambucana. In: CLIO - Série Arqueológica. n. 7. v. 1. Recife: EDUFPE, 1991.

LYRA, A. Tavares de. História do Rio Grande do Norte. 3. ed. Natal: Instituto Histórico e Geográfico do Rio Grande do Norte, 1998.

MARIZ, Marlene da Silva; SUASSUNA, Luiz Eduardo Brandão. História do Rio Grande do Norte. Natal: Sebo Vermelho, 2002.

MARTIN, Gabriela (Org.). Novos dados sobre as pinturas rupestres do Seridó no Rio Grande do Norte. In: Anais do I Simpósio sobre Pré-História do Nordeste Brasileiro. v. 1. Recife: EDUFPE, 1991.

MARTIN, Gabriela et. al. Escavação arqueológica do sítio Casa Santa, Carnaúba dos Dantas, RN. In: Clio - Série Arqueológica. n. 21. v. 2. Recife: EDUFPE, 2006.

MARTIN, Gabriela. A arte rupestre da região do Seridó, no Rio Grande do Norte e na Paraíba. In: Anais do I Seminário Internacional sobre Preservação da Arte Rupestre nos Sítios do Patrimônio Mundial. FUMDHAMENTOS. n. 5. São Raimundo Nonato/PI: FUMDHAM, jan. 2007.

A coleção arqueológica do Museu de Mossoró (RN). Mossoró: Fundação Vingt-Un Rosado, 1983. Série B. n. 235. (Coleção Mossoroense).

Arte Rupestre no Seridó: O Sitio Mirador de Parelhas (Rn). In: Clio - Série Arqueológica. n. 3. Recife: EDUFPE, 1985.

. Casa Santa: Um abrigo com pinturas rupestres do estilo Seridó, (Rn). In: Clio - Série Arqueológica. n. 2. Recife: EDUFPE, 1982.

. Fronteiras estilísticas e culturais na Arte Rupestre do Seridó RN. In: Clio Série Arqueológica. n. 18. Recife: EDUFPE, 2003. 
Identidades no sertão do Seridó. In: DANTAS, Marcelo (Org.). Antes. Histórias da Pré-História. v. 1. São Paulo: Centro Cultural Banco do Brasil, 2004.

. O cemitério pré-histórico "Pedra do Alexandre" em Carnaúba dos Dantas, RN. In: Clio - Série Arqueológica. n. 11. v. 1. Recife: EDUFPE, 1995-1996.

. Pré-história do Nordeste do Brasil. 3. ed. Recife: EDUFPE, 1999.

. Registro rupestre e registro arqueológico do nordeste do Brasil. Revista da SAB. v. 8. n. 1. São Paulo: SAB, 1994.

MARTIN, Gabriela; Anne-Marie Pessis. Área arqueológica do Seridó, RN, PB: Problemas de conservação do Patrimônio cultural. In: FUMDHAMENTOS. n. 2. v. 1. São Raimundo Nonato/PI: FUMDHAM, 2002/2003.

MARTINS, D. C.; BREDA, J. I.. Pa - salv - cb: divulgação museal. Revista da SAB. n. 14/15. São Paulo: SAB, 2001/2002b.

MARTINS, D. C.; BREDA, J. I.; OLIVEIRA, W. B.; OLIVEIRA, T.B.. Gestão e tratamento do acervo arqueológico: rta - salas Judite Ivanir Breda. Revista da SAB. n. 14/15. São Paulo: SAB, 2001/2002a.

MATOS, Alexandre. Da escavação ao Museu: caminhos da informação. In: Práxis ARCHAEOLOGICA. n. 2. Lisboa: Associação Profissional de Arqueólogos, 2007.

MEDEIROS, Tarcísio de. Proto História do Rio Grande do Norte. Rio de Janeiro: Presença/FJA, 1985.

MENESES, Ulpiano T. Bezerra de. A cultura material no estudo das sociedades antigas. In: Revista de História. n. 115. São Paulo: EDUSP, julho/dezembro, 1983.

MENSCH, Peter Van. O objeto de estudo da museologia. Rio de Janeiro: UNIRIO/UGF, 1994. 
MILLER JR., Tom O.. Do presente ao passado. In: Anais da II Reunião de Antropólogos do Norte e do Nordeste. Recife: UFPE; Brasília: CNPq; Rio de Janeiro: FINEP/ABA, 1991.

. Etnoarqueologia - implicações para o Brasil. Arquivos do Museu de História Natural da UFMG. v. VI - VII. Belo Horizonte: UFMG, 1981 - 1982.

Homem, ambiente e sistema: para uma arqueologia antropológica e intersubjetiva. Arquivos do Museu de História Natural da UFMG. v. VIII. Belo Horizonte: UFMG, 1988.

. Técnicas para arqueologia de salvamento: uma sugestão do Baixo Açu. Arquivos do Museu de História Natural da UFMG. v. VI - VII. Belo Horizonte: UFMG, 1981 - 1982.

MONTEIRO, Denise Mattos. Introdução à história do rio Grande do Norte. 2. ed. Natal: Cooperativa Cultural Universitária, 2002.

MOTTA, Márcia Maria M. História e Memórias. In: História - Pensar é fazer. Laboratório Dimensões da História. Rio de Janeiro: UFF, 1988.

MORALES, W. F. Os cachimbos cerâmicos do MAE/USP: apresentação de uma coleção. In: Revista do Museu de Arqueologia e Etnologia. n. 9. São Paulo: EDUSP, 1999.

MOURA, Pedro. Fatos da História do Rio Grande do Norte. Natal: Companhia Editora do RN, 1986.

NASCIMENTO, Ana; LUNA, Suely. Levantamento arqueológico do Riacho do Bojo, Carnaúba dos Dantas, RN, Brasil. In: Clio - Série Arqueológica. n. 13. v. 1. Recife: EDUFPE, 1998.

NASSER, Nássaro Antonio de Souza. Considerações preliminares sobre a arqueologia da bacia do rio Curimataú. Publicações Avulsas do Museu Goeldi. 
Programa Nacional de Pesquisas Arqueológicas: resultados preliminares do quarto ano 1968 - 1969. n. 15. Belém: Museu Paraense Emílio Goeldi, 1971.

Notas preliminares sobre a arqueologia do sistema Curimataú-Cunhaú. Publicações Avulsas do Museu Goeldi. Programa Nacional de Pesquisas Arqueológicas: resultados preliminares do primeiro ano 1965 - 1966. n. 6. Belém: Museu Paraense Emílio Goeldi, 1967.

. Nova contribuição à arqueologia do Rio Grande do Norte. In: Publicações Avulsas do Museu Goeldi. Programa Nacional de Pesquisas Arqueológicas: resultados preliminares do quinto ano 1969 - 1970. n. 26. Belém: Museu Paraense Emílio Goeldi, 1974.

OLIVEIRA, Cláudia A.. Abordagens teóricas dos grupos pré-históricos ceramistas no Nordeste. In: CANIDÉ: Revista do Museu de Arqueologia de Xingó. n. 1. Aracaju: UFS, dezembro de 2001.

ORIÁ, Ricardo. Memória e ensino de história. In: Bittencourt, Circe (Org.). 0 saber histórico na sala de aula. ed. 7. São Paulo: Contexto, 2002.

POMBO, Rocha. História do Estado do Rio Grande do Norte. Rio de Janeiro: Annuario do Brasil, 1922.

PROUS, André, et al. Os machados pré-históricos no Brasil - descrição de coleções brasileiras e trabalhos experimentais: fabricação de lâminas, cabos, encabamentos e utilização. In: CANIDÉ: Revista do Museu de Arqueologia de Xingó. n. 2. Aracaju: UFS, dezembro de 2002.

PROUS, André. Arqueologia brasileira. 2. ed. Brasília: UNB, 1992. . Os artefatos líticos: elementos descritivos classificatórios. In: Arquivos do Museu de História Natural - UFMG. Belo Horizonte: UFMG, v. 11, 1986/90.

QUEIROZ, Albérico N. de; CARDOSO, Glória Maria B. Nota prévia sobre a fauna holocênica de vertebrados do sítio arqueológico "Pedra do Alexandre", Carnaúba 
dos Dantas-RN, Brasil. In: Clio - Série Arqueológica. n. 11. v. 1. Recife: EDUFPE, 1995-1996.

RAHTZ, Philip. A Arqueologia e o público. In: RAHTZ, Philip. Convite à Arqueologia. Rio de Janeiro: Imago, 1989.

RIBEIRO, B. G.. Etnomuseologia: da coleção à exposição. In: Revista do Museu de Arqueologia e Etnologia. n. 4. São Paulo: EDUSP, 1994.

RIBEIRO, Berta G.. Museu e Memória. Reflexões sobre colecionamento. In: Ciência em museus. n. 1, v. 2, 1989.

ROBRAHN-GONZÁLES, Érika Marion. Arqueologia em perspectiva: 150 anos de prática e reflexão no estudo de nosso passado. In: Revista da USP. n. 44. São Paulo: EDUSP, dezembro/fevereiro, 1999-2000.

SANTOS JÚNIOR, Valdeci; PORPINO, Kleberson; SILVA, Abrahão Sanderson N. F. da. A megafauna extinta e os artefatos culturais de um tanque na região Central do Rio Grande do Norte. In: Anais do XIV Congresso da SAB: Arqueologia, Etnicidade e Território. Florianópolis: UFSC/SAB, 2007.

SANTOS, Myrian S. Objetos, memória e história. Observação e análise de um museu histórico brasileiro. In: Dados. Revista de Ciências Sociais. Rio de Janeiro, v. 35, n. 2, 1992.

SCATAMACCHIA, M. C. M.; DEMARTINI, C. M. C.; BUSTAMANTE, A. O aproveitamento científico de coleções arqueológicas: a Coleção Tapajônica do MAE/USP. In: Revista do Museu de Arqueologia e Etnologia. n. 6. São Paulo: EDUSP, 1996.

SCATAMACCHIA, Maria Cristina Mineiro; DEMARTINI, Célia Maria Cristina; BUSTAMANTE, Alejandra. O aproveitamento científico de coleções arqueológicas: a coleção Tapajônica do MAE/USP. In: Revista do Museu de Arqueologia e Etnologia. n. 6. São Paulo: EDUSP, 1996. 
SCHAER, Roland. L'invention des Musées. 2. ed. Paris : Gallimard, 2000.

SCHIAVETTO, Solange Nunes de Oliveira. Arqueologia Guarani: construção e desconstrução da identidade indígena. São Paulo: Annablume: FAPESP, 2003.

SCHWARCZ, Lilia Moritz. O espetáculo das raças: cientistas, instituições e questão racial no Brasil 1870-1930. São Paulo: Companhia das Letras, 1993.

SEMINÁRIO de ensino e pesquisas em sítios cerâmicos. Terminologia Arqueológica Brasileira para Cerâmica. Manuais de Arqueologia, n. 1. Paraná: UFP/CEPA, 1966.

SEREJO, Vicente. In: O sertão de nunca mais: Oswaldo Lamartine na Academia Norte-rio-grandense de Letras. Natal: Sebo Vermelho: Mossoró: Fundação Vingt-Un Rosado, 2002. Série B, n. 2100. (Coleção Mossoroense).

SILVA, Adrienne Costa da. As representações zoomórficas na sub-tradição Seridó. Dissertação de Mestrado. Recife: Programa de Pós-Graduação em História, Centro de Filosofia e Ciências Humanas - Universidade Federal de Pernambuco/UFPE, 2003.

SILVA, Antônio Campos e. Considerações sobre o Quaternário no Rio Grande do Norte. Mossoró: Fundação Guimarães Duque, 1983. Série B, n. 386. (Coleção Mossoroense).

. Contribuição ao estudo do Grupo Barreiras no Rio Grande do Norte. Arquivos do Instituto de Antropologia Câmara Cascudo. Natal: UFRN, 1969.

Levantamento do material pré-histórico do Oeste potiguar. Mossoró: Fundação Guimarães Duque, 1983. Série B, n. 329. (Coleção Mossoroense).

SOARES, Luci de Lourdes. Notas a lápis sobre a arqueologia norte-riograndense. Mossoró: Fundação Guimarães Duque, 1982. Série B, n. 381. (Coleção Mossoroense). 
SOUZA NETO, Luis Dutra; BERTRAND, Daniel. Mapeamento dos sítios arqueológicos do município de Florânia/RN. In: MNEME - Revista de Humanidades. n. 15. v. 7. Caicó (RN), abril/maio de 2005.

SOUZA NETO, Luis Dutra; BERTRAND, Daniel; SABINO, Ana Amélia de Brito. Análise da coleção lítica do Sítio Arqueológico Serrote dos Caboclos, município de Pedro Avelino/RN. In: MNEME - Revista de Humanidades. n. 16. v. 7. Caicó (RN), junho/julho de 2005.

SOUZA, Alfredo Mendonça de. História da arqueologia brasileira. Pesquisas: Antropologia. n. 46. São Leopoldo: Instituto Anchietano de Pesquisas, 1991.

Dicionário de Arqueologia Brasileira. Rio de Janeiro: ADESA, 1997.

TAMANINI, Elisabete. Museu, Educação e Arqueologia: prospecções entre teoria e prática. In: Revista do Museu de Arqueologia e Etnologia. Suplemento 3. São Paulo: EDUSP, 1999.

. O museu, a Arqueologia e o público: um olhar necessário. In: FUNARI, Pedro Paulo Abreu (Org.). Cultura material e arqueologia histórica. Campinas: EDUNICAMP, 1999. (Coleção Idéias).

TAUNAY, Affonso E. A Guerra dos Bárbaros. Mossoró: Fundação Vingt-Un Rosado, 1995. Série C, v. 863. (Coleção Mossoroense).

TENÓRIO, Maria Cristina. Coleta, processamento e início da domesticação de plantas no Brasil. In: TENÓRIO, Maria Cristina (Org.). Pré-história da Terra Brasilis. Rio de Janeiro: EDUFRJ, 2000.

TORRES, Ana Catarina. Estudo dos pigmentos do sítio pré-histórico Pedra do Alexandre - Carnaúba dos Dantas, RN. In: Clio - Série Arqueológica. n. 11. v. 1. Recife: EDUFPE, 1995-1996.

VIANA, Helder do N. Os usos do popular: coleções, museus e identidades, na Bahia e em Pernambuco, do início de século à década de 1950. Tese de Doutorado. 
São Paulo: Programa de Pós-Graduação em História Social, Faculdade de Filosofia, Letras e Ciências Humanas - Universidade de São Paulo/USP, 2002.

VIDAL, Irma Asón. Projeto arqueológico do Seridó: sítio Pedra do Chinelo. In: Clio Série Arqueológica. n. 17. v. 1. Recife: EDUFPE, 2002. 